\title{
Executive (In)Decision?
}

Explaining Delays in Canada's Defence Procurement System, 2006-2015

\author{
by \\ Jeffrey Francis Collins
}

A thesis submitted to the Faculty of Graduate and Postdoctoral Affairs in partial fulfillment of the requirements for the degree of

Doctor of Philosophy

In

Political Science

Carleton University

Ottawa, Ontario

(C) 2018

Jeffrey Francis Collins 


\begin{abstract}
This dissertation asks how delays in Canada's defence procurement system can be explained. In answering this question, the hypothesis tested is that of the 'political executive'; the political body composed of the prime minister, cabinet and their advisors who sit at the apex of the federal government. With final decision-making powers over defence policy and budgets, the political executive has been inferred in existing scholarship as a decisive factor in delaying Major Crown Projects (MCPs) from moving through the procurement process but this has never been the subject to a scholarly analysis. Three other independent variables commonly identified in the literature as causing procurement delays were tested alongside the political executive: (1) the defence procurement bureaucracy; (2) the defence industry; (3) and Canada's military alliances and involvement in the Afghanistan war (2001-2014). Delays are treated as the dependent variable and are defined as a MCP not meeting its original planned project milestone dates.

The dissertation relied upon four case studies in performing this analysis: The Joint Support Ships, the Medium Support Vehicle System - Standard Military Patter trucks, the Fixed-Wing Search and Rescue aircraft, and the Halifax-class Modernization/Frigate Life Extension. All four trace their beginnings to the Liberal governments of Jean Chrétien (1993-2003) and Paul Martin (2003-2006), but it was under the Stephen Harper Conservative government (2006-2015) that all were adopted into that government's procurement plans and it is in this period where delays occurred, for the first three case studies, and where apparent success was established with the fourth, the Halifax-class Modernization. (The first three case studies all experienced delays and are anywhere from seven to fourteen years behind their original schedule.) Relying upon process-tracing and the bureaucratic politics framework, this research concluded with a hypothesis not completely proven: the political executive can partly account for delays by not establishing clear policy guidance and governance models before a MCP reaches the project definition stage; however, a complete accounting for procurement delays is not possible without factoring in at least one the three independent variables, especially the defence procurement bureaucracy.
\end{abstract}




\section{Acknowledgments}

This project was a five-year odyssey that could not have happened without the support of many individuals and groups. First, thanks go to my supervisory team of Professors Elinor Sloan, Kim Richard Nossal and Jonathan Malloy. Professor Sloan deserves special mention for encouraging me to research and stick with this dissertation's subject matter, especially during those times when I waivered. I am glad I heeded her advice (and deadlines) as this project's subject matter could not have been more timely. Likewise, to the nearly two dozen interviewees who took time from their busy schedules to address my lengthy questions, thanks. Most of you asked to remain anonymous but without your insights this project simply would not have been able to capture the many nuances of contemporary defence procurement. You know who you are. Thank you.

I also extend my deep appreciation to Sean Speer and Dr. David S McDonough of the Macdonald-Laurier Institute and Dr. Brian Bow and Andrea Lane at the Centre for the Study of Security and Development at Dalhousie University who have provided me with a national platform to network, publish and test my ideas. Likewise, my thesis benefitted from professional feedback gained at the 2017 International Studies Association conference in Baltimore, Maryland and the 2016 defence procurement conference hosted by Le Centre interuniversitaire de recherche sur les relations internationales du Canada et du Québec (CIRRICQ) at Gatineau, Quebec. A special 'shout-out' to Jacques Fauteux, Dr. David Perry, Rachael Bryson and especially Heather Diamond for their assistance; Dr. Alex Marland for the motivation to complete the thesis on time; and James Sullivan and the Government of PEI for the support to allow a new provincial civil servant to study the procurement processes of our federal cousins. And finally, a very special thank you goes to my number one supporter and best friend, Jenny Mason and to our cat Charli (my personal editor). Thanks for putting up with the late nights and long weekends. Normalcy has returned. 


\section{List of Acronyms Used}

ADM (Mat) - Assistant Deputy Minister (Materiel)

AOR - Auxiliary Oil Replenishment ships

CA - Canadian Army

CAF - Canadian Armed Forces

CCG - Canadian Coast Guard

CDS - Chief of Defence Staff

CITT - Canadian International Trade Tribunal

DM - Deputy Minister

DND - Department of National Defence

FWSAR - Fixed-Wing Search and Rescue

IC - Industry Canada

IRBs/ITBs - Industrial Regional Benefits/Industrial Technical Benefits

ISEDC - Innovation, Science and Economic Development Canada

JSS - Joint Support Ships

$\mathrm{MC}$ - Memorandum to Cabinet

MilCOTS - Military Commercial Off-the-Shelf

MLVW - Medium Logistics Vehicle Wheeled

MSVS - Medium Support Vehicle System

NRC - National Research Council

PSPC - Public Services and Procurement Canada

PWGSC - Public Works and Government Services Canada

RCAF - Royal Canadian Air Force

RCN - Royal Canadian Navy

RFP - Request for Proposals

SMP - Standard Military Pattern

SOR - Statement of Requirement

TBS - Treasury Board of Canada Secretariat

TKMS - ThyssenKrupp Marine Systems

UOR - Urgent Operational Requirement 


\section{List of Tables}

Table 1: The Defence Procurement System: Organizational Roles and Responsibilities........50

Table 2: The Defence Procurement Process: Stages and Key Components.....................55

Table 3: JSS Project Milestones............................................... 76

Table 4: MSVS-SMP Project Milestones......................................... 120

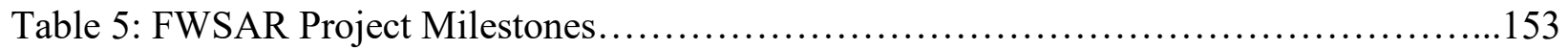

Table 6: HCM/FELEX Project Milestones................................................200 


\section{Contents}

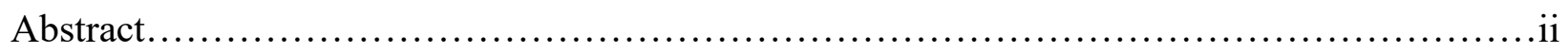

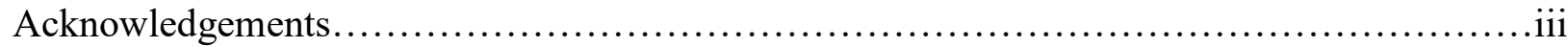

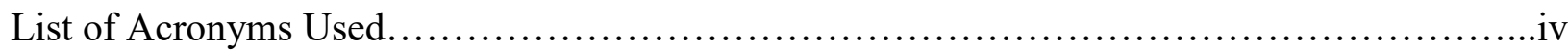

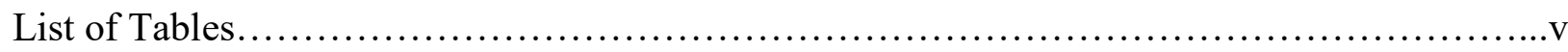

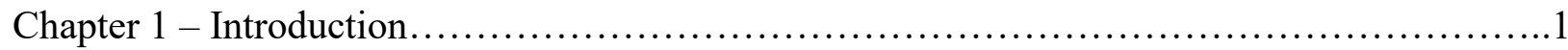

Hypothesis and Research Question..........................................

Literature Review..........................................................

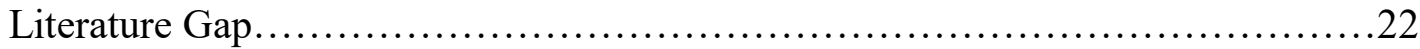

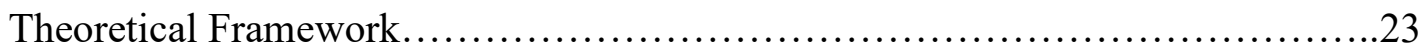

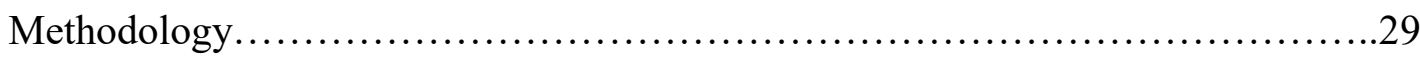

Chapter Outline.................................................................

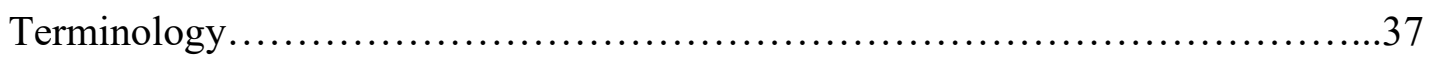

Chapter 2 - The Defence Procurement System, Process and Policy Environment.................38

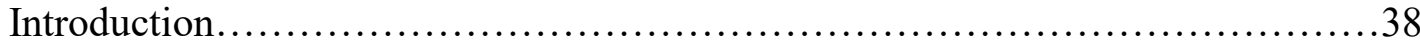

The Defence Procurement System...............................................39

The Defence Procurement Process.............................................55

External Defence Policy Environment........................................56

Internal Defence Policy Environment.......................................62

Bringing It All Together.................................................. 73

Chapter 3 - Joint Support Ships....................................................... 74

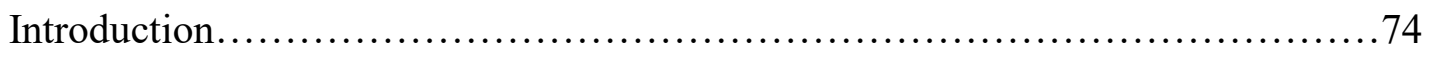

Political Executive Decisions..................................................76

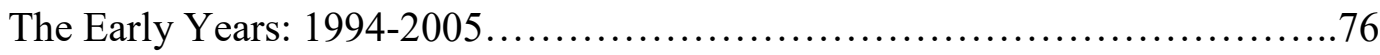

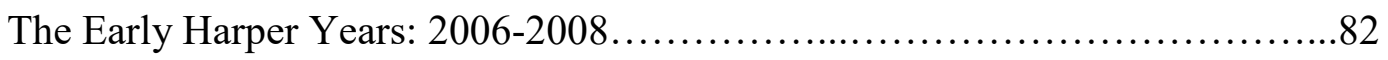

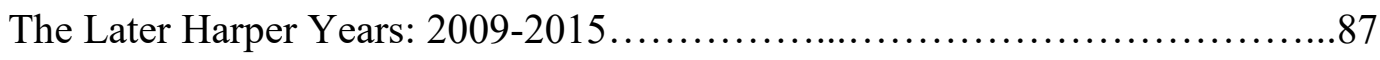

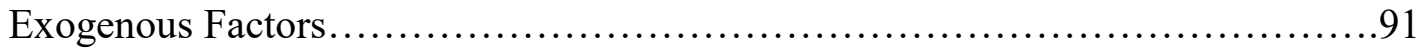

Defence Procurement Bureaucracy .........................................91 


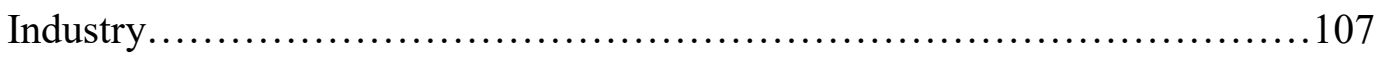

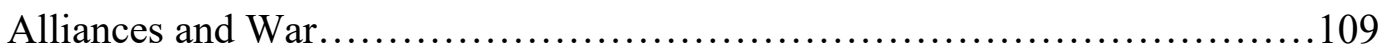

Bringing It All Together.................................................110

Chapter 4 - Medium Support Vehicle System - Standard Military Pattern.................... 117

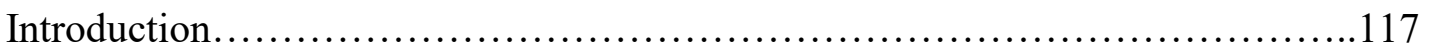

Political Executive Decisions.............................................. 120

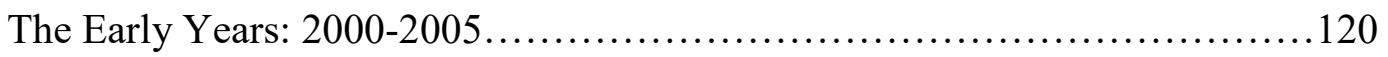

The Early Harper Years: 2006-2009.....................................122

The Later Harper Years: 2010-2015 .....................................128

Exogenous Factors........................................................ 130

Defence Procurement Bureaucracy .......................................130

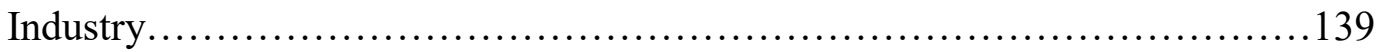

Alliances and War.................................................. 142

Bringing It All Together..................................................142

Chapter 5 - Fixed-Wing Search and Rescue Aircraft.................................... 150

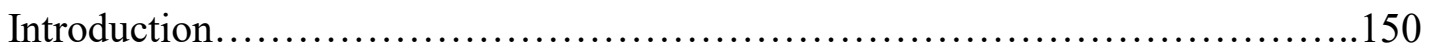

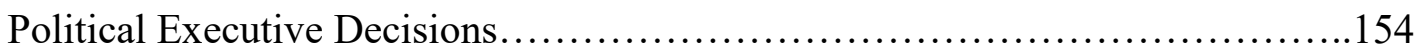

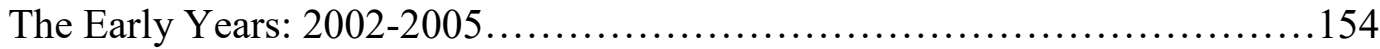

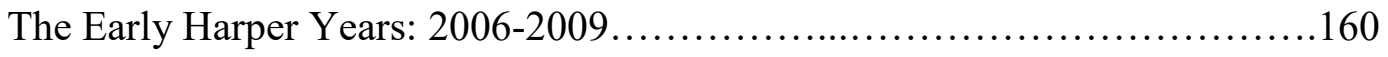

The Later Harper Years: 2010-2015 ........................................167

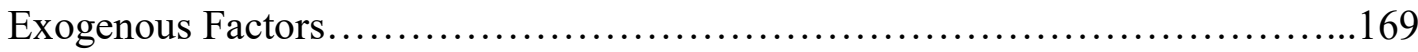

Defence Procurement Bureaucracy.........................................169

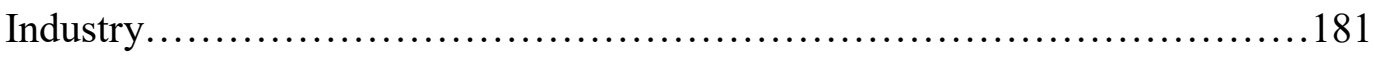

Alliances and War................................................... 187

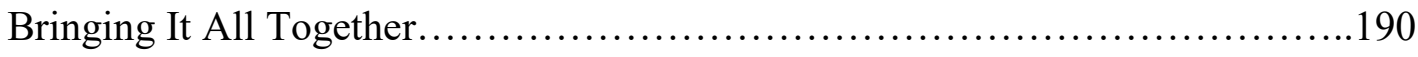

Chapter 6 - Halifax-Class Modernization/Frigate Life Extension.............................195

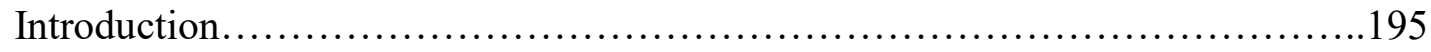

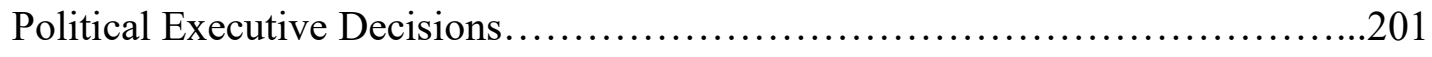




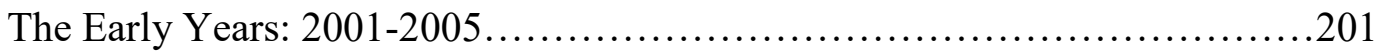

The Harper Years: 2006-2015 ....................................203

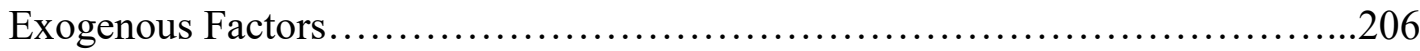

Defence Procurement Bureaucracy.....................................206

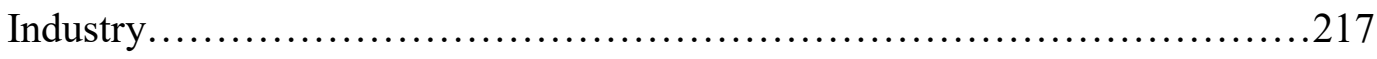

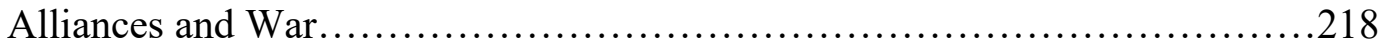

Bringing It All Together..............................................219

Chapter 7 - Conclusion......................................................223

Research Question and Hypothesis......................................223

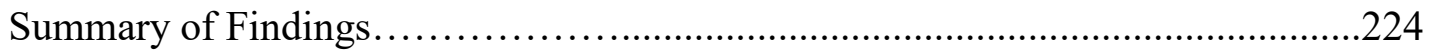

Contribution to Literature ...........................................230

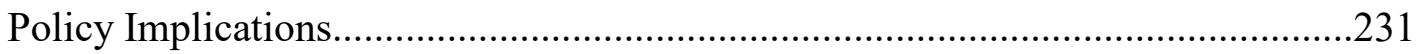

Areas for Future Research.........................................235

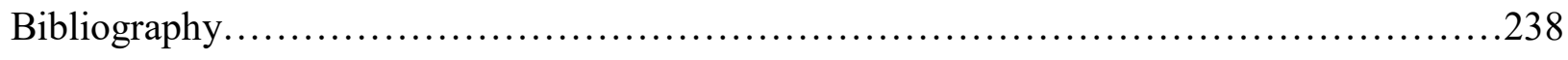

Sources.............................................................238

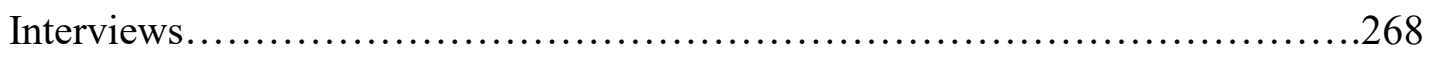

Appendix A - Ethics Clearance.......................................................269 


\section{Chapter 1 - Introduction}

\section{Introduction}

Canada's defence procurement program has been the subject of much public comment and political angst. For the better part of the past decade there has been a constant stream of news stories on a multitude of multi-billion dollar projects that have become mired in delays. ${ }^{1}$ Whether it is jets, patrol ships, or helicopters, it is now quite common for a major military procurement, or Major Crown Project (MCP) in federal contracting parlance, to take up to fifteen years or longer to acquire. ${ }^{2}$ Such delays carry a negative burden for the Canadian Armed Forces (CAF), forcing the military to spend more scarce dollars on maintaining aging equipment, and curtailing operations due to a lack of capabilities. ${ }^{3}$ By the Department of National Defence's (DND) own estimation, in 201770 percent of MCPs "have not been delivered on time". ${ }^{4}$ Perversely, as Kim Richard Nossal observes, a procurement delay is likely worse than a total failure because "it attracts comparatively less attention while often wasting far more money and causing far more serious degradation in Canadian military capacity" as aging equipment becomes increasingly

\footnotetext{
${ }^{1}$ For a sampling see: Pugliese, David. "Nearly half of military contracts had no competition, report finds." The Ottawa Citizen, June 11, 2007; Ivison, John. "From helicopters to fighter jets, problems facing Canada's defence procurement are systemic." The National Post, May 28, 2015; Chase, Steven. "Military left waiting on big-ticket items as Liberals shrink funding in budget." The Globe and Mail, March 22, 2016; The Canadian Press, "After years of missteps, Canadian military officials hope procurement now on track," CBC News, accessed July 9, 2017. http://www.cbc.ca/news/politics/military-procurement-national-defence-canada-spending-1.4197017.

${ }^{2}$ A Major Crown Project is defined by the Treasury Board Secretariat as a project costing more than $\$ 100$ million. On duration of delays see: Williams, Alan S. Reinventing Canadian Defence Procurement (Kingston, ON: Defense Management Studies Program, School of Policy Studies, Queen's University, 2006, 95; Canada. Department of National Defence. Report to the Minister of National Defence by the Advisory Committee on Administrative Efficiency. Ottawa: 2003. 33; Canada. Department of National Defence. Chief Review Services. Perspectives on the Capital Equipment Acquisition Process - Final Report. Ottawa: 2006. 1; Granatstein, Jack L. Canada's Army: Waging War and Keeping the Peace. Toronto: University of Toronto Press, 2011. 427.

${ }^{3}$ Canada. Parliament. Senate. Standing Committee on National Security and Defence. Military Underfunded: The Walk Must Match the Talk. 1st sess., 42nd Parliament, Report No. 10, April 2017, 33-36.

${ }^{4}$ Canada. National Defence and the Canadian Armed Forces. Strong, Secure, Engaged: Canada's Defence Policy (Ottawa: 2017), 74.
} 
unreliable, putting its users - the men and women of the CAF - at greater risk of injury or death. ${ }^{5}$ Delays also impact new projects' budgets as inflation chips away at purchasing power, thus leaving the $\mathrm{CAF}$ in a position of having to choose between fewer new units of equipment or equal numbers but with less capabilities.

Blame for these delays has been partially attributed to the lack of public support for sustainable defence funding because of Canada's geostrategic position and the protection the country receives from the U.S. alliance. To quote Donald Macdonald, Pierre Trudeau's minister of national defence, "[t] here is no obvious level for defence expenditures in Canada, a judgment must be made on proposed defence activities in relation to other Government programs". ${ }^{6}$ Others suggest that it is the structure of the procurement process itself, which is currently split among three departments, DND, Public Works and Government Services Canada (PWGSC), and Industry Canada (IC); a situation that is often singled out as uniquely Canadian given that some of our allies - like the United Kingdom - have separate defence procurement agencies with an accountable political minister. ${ }^{7}$ The lack of enough trained procurement personnel in DND has also been identified by the Auditor General, think-tank reports and even the government's latest White Paper as hampering timely delivery. ${ }^{8}$ Still, none of these explanations is completely satisfying in and of themselves. For example, the UK has a separate procurement agency but it

\footnotetext{
${ }^{5}$ Kim Richard Nossal, Charlie Foxtrot: Fixing Defence Procurement in Canada (Toronto: Dundurn Press, 2016), 24.

${ }^{6}$ Stone, Craig and Binyam Solomon. "Canadian Defence Policy and Spending." Defence and Peace Economics 16, no. 3 (2005): 150 .

${ }^{7}$ Williams, Reinventing Canadian Defence Procurement.; Nossal, Kim R. Charlie Foxtrot: Fixing Defence Procurement in Canada. Toronto: Dundurn, 2016. For a counterview, see: Stone, Craig. A Separate Defence Procurement Agency: Will It Actually Make A Difference? (Calgary: Canadian International Council and Canadian Defence and Foreign Affairs Institute, 2012).

${ }^{8}$ Canada. National Defence and the Canadian Armed Forces. Strong, Secure, Engaged, 75; Canada. Office of the Auditor General, Chapter 9 - National Defence (Ottawa:1987); Canada. Office of the Auditor General, Chapter 17 - National Defence (Ottawa:1992); Canada. Office of the Auditor General, Chapter 4 - National Defence: Equipping and Modernizing the Canadian Forces (Ottawa:1998); David Perry. 2015 Status Report on Major Defence Equipment Procurements (Calgary: Canadian Global Affairs Institute, 2015).
} 
too still has delays. ${ }^{9}$ Australia has a very different geostrategic reality than Canada, yet its Air Warfare Destroyer project is years behind schedule. ${ }^{10}$ The Pentagon employs thousands of personnel in defence acquisition and yet is no farther ahead in avoiding schedule slippages. ${ }^{11}$

\section{Research Question and Hypothesis}

When it comes to defence procurement and procurement delays, existing scholarship fails to bridge the gap between the role key political actors play in defence policy-making and procurement. For this reason, this dissertation posits the following question: how can we account for delays in Canada's defence procurement program? This dissertation's core argument is that the political executive is central to understanding why there are delays in Canada's current procurement program. Delays are defined as MCPs not meeting their original planned project milestone dates that are established once a project is officially identified by DND as a soughtafter capability (see Chapter Two for a thorough explanation of the procurement process). The prime minister, the cabinet and their political advisors comprise the 'political executive' and in defence procurement literature are generally viewed as ancillary to the procurement system. In contrast, the political executive is where key high-level decisions are made concerning defence procurement. First, the political executive sets out formal government policy objectives with

\footnotetext{
${ }^{9}$ Andrew Chuter, “Audit Cites UK's Strides on Procurement Fixes”, DefenseNews. Com (16 January 2015): http://www.defensenews.com/story/defense/policy-budget/budget/2015/01/13/national-audit-office-ukprocurement/21693759/.

${ }^{10}$ Julian Kerr, "First-of-class Hobart launched as government discloses further delays, costs", Jane's Defence Weekly, 25 May 2015. http://www.janes.com/article/51644/first-of-class-hobart-launched-as-government-disclosesfurther-delays-costs; Pickford, Andrew and Collins, Jeffrey F. Canada can only learn so much from Australian defence policy (Ottawa: Macdonald-Laurier Institute, 3 March 2016). http://www.macdonaldlaurier.ca/canada-canonly-learn-so-much-from-australian-defence-policy-andrew-pickford-and-jeffrey-collins-for-inside-policy/.

${ }^{11}$ Greenwalt, William C. Five Factors Plaguing Pentagon Procurement (Washington, D.C.: American Enterprise Institute for Public Policy Research, 2013).
} 
either a defence White Paper, like the Trudeau government's 2017 Strong, Secure, Engaged: Canada's Defence Policy, or a defence policy statement, like the Harper government's June 2006 “Canada First Defence Procurement Strategy" announcement. Such policy documents set the parameters of defence policy and establish procurement priorities, providing clarity to the public service and armed forces on the capabilities and specific MCPs the government of the day wants to see brought to fruition to achieve its defence policy goals. In this sense, and based on the expert input of the CAF and DND, the political executive can be said to provide broad policy direction on procurement, aligning some (but not all) of the military's wants with the competing demands on the treasury and high-level political support. Related to this, the political executive, generally at a defence policy-specific cabinet committee or the prime minister-led priorities cabinet committee, will approve (or not) a defence policy White Paper and any MCPs that are deemed sensitive enough for political and cost reasons to warrant political executive approval (e.g. the 2008 Canada First Defence Strategy had its own ad-hoc cabinet committee). ${ }^{12}$

Perhaps even more importantly, the political executive, specifically the minister of finance and the prime minister, determine the fate of a MCP through their control of government purse strings. ${ }^{13}$ Decisions are made every year in the Government of Canada budget on DND/CAF's financial priority against competing demands from other departments, agencies and policy goals (e.g. provincial transfers). In short, the budget determines how much money the political executive is willing to give to National Defence and its procurement 'wish-list'. Even a project with policy endorsement can have its funding deferred into the future with the consequent

\footnotetext{
${ }^{12}$ Stone and Solomon, "Canadian Defence Policy and Spending", 151-152; Smith, Marie-Danielle. "When cabinet decides: Parsing Canadian defence politics." Embassy News, March 9, 2016.

${ }^{13}$ D.W. Middlemiss and J.J. Sokolsky, Canadian Defence: Decisions and Determinants (Toronto: Harcourt Brace Jovanovich Canada Inc., 1989), 73.
} 
risk of possible capability-cost trade-offs, like the Canadian Surface Combatant project, or outright cancelled, as happened with the Close Combat Vehicle in 2013. ${ }^{14}$ Finally, defence procurement is subject to political executive decisions in other policy areas including but not limited to CAF overseas deployments, trade agreements, relations with allies, and regional economic development (e.g. shipbuilding under the National Shipbuilding Strategy). ${ }^{15}$ Canadian defence policy scholars concede on these points but with the exception of a handful of singular, historical case studies discussed below, a systematic appraisal of the political executive's involvement in contributing to procurement delays is still lacking in Canada.

While other explanations - defence procurement bureaucracy, the state of domestic and global defence industry, alliances and war - are important to understanding Canadian defence procurement delays the role of the political executive and its impact on possibly delaying acquisitions requires further examination. For the purposes of this dissertation, the independent variable will be the political executive while the dependent variable will be procurement project delays. In addition, three exogenous independent variables frequently identified in the literature as contributing to delays - the defence procurement bureaucracy, the defence industry, Canada's military alliances and the impact of the Afghanistan war (2001-2014) will be considered. These exogenous independent variables are used to test the explanatory power of the hypothesis.

\footnotetext{
${ }^{14}$ Canada. Parliament. Office of the Parliamentary Budget Officer. The Cost of Canada's Surface Combatants (Ottawa: 2017); Canada. National Defence and the Canadian Armed Forces. "Chief of Defence Staff and Army Commander issue a joint statement on the decision not to proceed with the procurement process for the Close Combat Vehicle," Statement, December 20, 2013.

15 Savoie, Donald J. Governing from the Centre: The Concentration of Power in Canadian Politics Toronto: University of Toronto Press, 1999, 136-137.
} 


\section{Literature Review}

Attributing blame for delays and cost overruns in Canadian defence procurement has been the subject of much commentary but little scholarly analysis. In fact, only three scholarly books have been written on the Canadian defence procurement system at all. The first is Alan S. Williams's Reinventing Canadian Defence Procurement. Published in 2006, Williams, a former Assistant Deputy Minister of Materiel, or ADM (Mat) - the top procurement bureaucrat in DND, states that there are two criteria necessary for effective defence procurement: solid strategic planning and budgetary control. Problems often arise when ministers fail to grasp that sustainment costs of existing equipment exceed costs of buying new equipment and that new equipment, given its technical sophistication, costs more to sustain than what was replaced. Williams blames individual actors and institutional cultures for generating procurement delays. Delays are often the result of "internal debates between public servants and politicians over firm selections." Williams pointed out how a lack of prioritizing of acquisition projects creates a vacuum that is filled by whatever "pet projects" the CDS or defence minister want. (Although, of note, the introduction of an annual Defence Acquisition Guide by the Harper government in 2014 has addressed, to a degree, this problem). The institutional cultures of both politicians and civil servants view DND as like any other department in the federal government: it gets public money and must live with its means. In contrast, the military views its role as to protect Canadians and Canada's interests. Consequently, the military will sometimes "downplay total life-cycle costs of a weapon" in order to get cabinet approval. Williams argues for a separate procurement agency with a responsible minister, improved parliamentary oversight, and better transparency on 
project reporting. He also advises that Ottawa enter into more rentals, equipment leases, and bilateral purchasing agreements to create economies-of-scale. ${ }^{16}$

In Aaron Plamondon's The Politics of Military Procurement, the author contends that military procurement is at the mercy of partisan political considerations and there is not a primary desire to ensure the CAF gets the right capabilities. The procurement process, he notes, is a "mass of bureaucracy" driven by too many reporting requirements. Political considerations, such as regional economic development and supporting industry, are often at the heart of making Canada's procurement system inefficient by “drastically extend[ing] the timeline of acquisition". The corollary of extended timelines means that projects become increasingly politically vulnerable and subject to cancelation. Plamondon finds that cabinet often delays final approval because of unsatisfied political considerations. Delays and cost issues are also a product of Canada having a small internal defence industry market, leading to overseas purchasing and customizing foreign equipment. ${ }^{17}$

More recently, in 2016, Kim Richard Nossal's Charlie Foxtrot argues that defence procurement is "one of the most difficult and complex policy tasks facing all liberal democratic governments". ${ }^{18}$ Nossal views Canada's procurement program through a social science lens in that it is a "system of problems that produces dissatisfaction". ${ }^{19}$ In this sense, he fingers the political environment as the primary source for delays, with Canadian politicians routinely “playing politics" with defence procurement. ${ }^{20}$ Canadian politicians can get away with this because of the country's "Security Imaginary", that is, what a citizenry imagine their country's

\footnotetext{
${ }^{16}$ Williams, Reinventing Canadian Defence Procurement, 2, 5-6, 24, 25-26, 31, 32, 36-37.

${ }^{17}$ Aaron Plamondon, The Politics of Procurement (Vancouver: UBC Press, 2010), xiiii, 9, 10, 29.

${ }^{18}$ Nossal, Charlie Foxtrot, 23.

19 Ibid., 24.

${ }^{20}$ Ibid., 29-30, 103.
} 
security situation to be. For most Canadians, they imagine their country to be a benign power facing few threats. Consequently, this imaginary fosters a "highly permissive environment" for Canadian politicians to use defence procurement as a political cudgel against one another without paying a price at the polls for when projects go awry. In fact, it is also true that, "there are no political rewards when governments do get defence procurement right" either. This situation is accentuated by the reality that there are too many lines of accountability represented by three ministers responsible for three departments with three different mandates. Such diffusion slows the process because of inter-departmental tensions. ${ }^{21}$ Nossal regards Canadian cabinet ministers as the "principals in defence procurement" with bureaucrats as the agents. cabinet ministers could help ameliorate delays in defence procurement by crafting a White Paper, published in its name, that reflects Canada's security imaginary and its geostrategic position in the world rather than adopting the standard, and unaffordable, "ideal" military structure usually proposed by the CAF, which ministers quickly abandon when confronted with fiscal constraints on the treasury. Other solutions involve generating bi-partisan consensus on defence policy as the Liberals and Conservatives "have a fundamentally shared view of the world", and the establishment of a joint parliamentary committee on defence to maintain the bipartisanship consensus. $^{22}$

Apart from these books, understanding Canadian defence procurement woes have been the subject of a varied but limited selection of think-tank reports, articles, and chapters from a handful of the same authors. Sloan finds multiple problems in DND's own internal processes. Requirement proposal documentation tends to morph into "wish list" thinking by military

\footnotetext{
${ }^{21}$ Ibid., 90, 107, 110-113.

${ }^{22}$ Ibid., 115-119, 136, 152, 154-155, 162.
} 
personnel keen on getting the latest, most expensive equipment, regardless of whether it is necessary for Canada's needs. The interdepartmental nature of procurement is also singled out as a source of delays, though it can be remedied by the introduction of a single ministerial point of accountability. Lastly, Sloan finds that cabinet's tendency to accept estimated ROM costs as concrete early in the procurement process all but ensures that capability-cost trade-offs will ensue as inflation chips away at budgets. An ability to revisit such costing is necessary. ${ }^{23}$

Middlemiss remarks that procurement decision-making is always constrained by external military-oriented factors and domestic, political-economic factors. However, the budget is the constraint on procurement. The defence budget is what makes planning so "inherently unpredictable", contributing to delays as inflation depreciation sets in. In the end, any Canadian government confronts four basic procurement options: (1) indigenous, design and building; (2) joint ventures with allies; (3) licensed production of foreign designs; (4) and offshore procurement. He notes that often missing from procurement commentary is the role provinces play in lobbying government for industrial offsets. ${ }^{24}$

The issue of capability-cost trade-offs is at the centre of Lagassé's 2012 study of the CAF's major acquisition projects. Essentially, he asserts that the main challenge is affordability - the result of three factors: (1) an overburdened and inexperienced project management staff which failed to contain the "wish list" thinking of the CAF's requirements staff; (2) a defence policy document, the Canada First Defence Strategy, which initially created an impression of nearly unlimited amounts of money to fund acquisitions; (3) and a neglecting of responsibility by

\footnotetext{
${ }^{23}$ Sloan, Elinor. Canadian Defence Commitments: Overview and Status of Selected Acquisitions and Initiatives (Calgary: Canadian Defence and Foreign Affairs Institute, 2014), 4, 6-7.

${ }^{24}$ Dan Middlemiss, "Defence Procurement in Canada," in Canada's International Security Policy, eds. David B. Dewitt and David Leyton-Brown (Scarborough, ON: Prentice-Hall Canada Inc., 1995), 394-395, 396-397, 403.
} 
procurement staff in checking the military's specification demands. Lagassé recommends that the government establish equipment priorities with matching financial provisions, and boost the human resource capabilities of DND Materiel division, ADM (Mat). ${ }^{25}$

In a 2015 report based on interviews with political advisors, public servants, and military officials, Perry finds that there is a lack of trust between the political level and those in the procurement system. There are also trust issues between DND and other departments. During Canada's participation in the Afghanistan war (2001-2014), projects were allowed to bypass normal procedures, particularly offset requirements. Furthermore, DND's requirements are too technical and not easily understood by other departments. Trust is also lacking between industry and the bureaucracy with the former feeling that government is inflexible on working arrangements and does not understand the private sector. The government, meanwhile, sees industry as trying to maximize profit at the expense of the treasury. ${ }^{26}$ In another article, Perry finds that with the current procurement cycle, the Afghanistan war was partially responsible for delays and costs increases. The war, he suggests, altered the planned acquisition cycle by prioritizing mission-specific equipment over other needs. This put pressure on DND's project management teams, increased wear and tear on existing equipment, and consumed large portions of the billions allocated to defence in 2005-2006. ${ }^{27}$

The issue of external factors impacting procurement is also the subject of Douglas L. Bland's edited volume, Canada Without Armed Forces? Bland attributes problems to the failure of the DND and the CAF to adjust to post-Cold War realities. He views DND as too wedded to

\footnotetext{
${ }^{25}$ Philippe Lagassé. Recapitalizing the Canadian Forces' Major Fleets (Calgary: CIC and CDFAI, 2012).

${ }^{26}$ Dave Perry. Putting The 'Armed' Back Into The Canadian Armed Forces: Improving Defence Procurement in Canada (Ottawa: Macdonald-Laurier Institute, 2015), 12, 13, 17.

${ }^{27}$ David Perry, "Canada's Seven Billion Dollar War," International Journal 63, no. 3 (2008): 716-717, 722.
} 
Cold War-era thinking, when geopolitical stability and operational priorities in defending West Germany and the North Atlantic meant that defence management was simply a matter of replacing existing equipment with newer ones. Cost and capability assessments were relatively predictable and easy in such an environment. ${ }^{28}$

Meanwhile, Sean M. Maloney attributes procurement problems to the absence of clear policy direction from the government. Without prioritizing intended procurement projects interservice rivalry occurs which increases delays and wastes resources. He calculates that the shortterm thinking of politicians will prevent such priority setting as they seek "to retain as much flexibility as possible in order to stay in power". ${ }^{29}$

Ugurhan Berkok identifies procurement problems to be the result of the split in responsibilities between departments: Public Services and Procurement Canada handle all the federal government contracting duties while DND/CAF aims for obtaining the best equipment for its operational needs - a goal that brushes up against the government's political industrial and regional objectives. Berkok argues that defence procurement becomes a "bargaining process between DND and regional development agencies" - which favour larger projects for different reasons - and the Treasury Board Secretariat and the Department of Finance who desire "tight fiscal constraints that do not anger the taxpayer." Government often finds itself in a weak position when it comes to approving funding for procurement projects: the technical know-how is with the armed services. Such "information asymmetries" are endemic in the procurement process and are partially responsible for delays. Berkok's solution is to reduce the duplications

\footnotetext{
${ }^{28}$ Douglas L. Bland, ed., Canada without Armed Forces? (Montreal: McGill-Queen's University Press, 2004), 13, $17,19$.

${ }^{29}$ Sean M. Maloney, Force Structure or Forced Structure? The 1994 White Paper on Defence and the Canadian Forces in the 1990s (Montreal: Institute for Research on Public Policy, 2004), 2, 5.
} 
between DND and PWGSC, cooperate with allies, and develop an industrial policy targeted at niche capabilities. ${ }^{30}$

Craig Stone states that DND is the single largest purchaser of goods in the federal government, spending some 68 percent of the government's monies dedicated to buying equipment. He pinpoints problems with the Treasury Board's requirements that all projects costing over $\$ 100$ million be acquired at "best value" and not for what is best for the military. Best value, Stone argues, is a mishmash of "price, technical merit, and quality". Still, Stone is not completely sold on the idea of having a separate procurement system, noting that under Public Works and Government Services Canada (now PSPC) military procurement is at least firmly in civilian control. The main challenge for procurement will be finding a way to strike a balance between weapon systems which will be used for two to three decades but whose technology is constantly changing. ${ }^{31}$

Charles Davies, a former senior CAF officer in the ADM (Mat) division at DND, suggests that most public commentary is uninformed about Canada's defence procurement system because "procurement mechanisms are an opaque mystery". Therefore, the key to understanding the procurement system is knowing the administrative machinery of government and the legal and regulatory basis which underpin it. While successive Canadian governments have demanded better responsiveness and accountability on defence procurement this is complicated due to multiple ministerial points of authority and dispersed accountability. Such a set-up creates a "high degree of variability" in the interactions among key players and their

\footnotetext{
${ }^{30}$ Ugurhan Berkok, "Canadian defence procurement", in Defence Procurement and Industry Policy: A small country perspective, eds. Stefan Markowski, Peter Hall and Robert Wylie (New York: Routledge, 2010), 211, $222,224$.

${ }^{31}$ Craig Stone, "Defence Procurement and Industry," in Canada's National Security in the Post-9/11 World, ed. David S. McDonough (Toronto: University of Toronto Press, 2012), 75, 77, 80.
} 
respective organizations with "individual procurement outcomes often tend[ing] to be more dependent upon personalities and relationships than upon any common, consistent interdepartmental business process". Such a dynamic, he concludes, blurs accountability, weakens effective oversight, and undermines the ability to execute projects or address problems. ${ }^{32}$

Aside from general critiques of Canadian defence procurement, a number of scholars have done singular procurement case studies. J.W. Arseneault examined the DDH 280 destroyer program from the 1970s. He finds that the powerful personality of the Pearson-era defence minister, Paul Hellyer, was so effective in minimizing bureaucratic in-fighting and directing the bureaucracy to his vision on budgetary constraints that the navy intentionally undervalued the cost and schedule estimates of the four destroyers to get cabinet approval. Arsenault uses this case study to illustrate how a rational-model theory, like realism, fails at explaining defence procurement. Instead, Canadian defence procurement decisions and process are more reflective of group interests, elite preferences, and environmental forces. ${ }^{33}$

In reviewing the Brian Mulroney government's 1986 decision to buy a Low Level Air Defence platform, William Fox finds that cabinet and its committees lay at the heart of procurement decision-making. cabinet ministers, he reminds us, are also MPs who represent ridings, provinces, and in some cases, ethnic or cultural groups, in addition to their party and department. Cabinet decisions must result in an agreement or, at least, no public disagreement. Inter-governmental politics and cabinet decisions are often the result of "the relative power and

\footnotetext{
${ }^{32}$ Charlies Davies, "Understanding Defence Procurement," Canadian Military Journal 15, no. 2 (2015): 5-15.

${ }^{33}$ J.W. Arseneault, "The DDH 280 Program: A Case Study of Governmental Expenditure Decision-Making," in Canada's Defence Industrial Base, ed. David G. Haglund (Kingston: Ronald P. Frye \& Company, 1988), 124, 127, 133-134.
} 
influence of...individual" ministers, and less about formal processes. Once a planned defence project goes before cabinet for approval it becomes subject to political considerations, stretching from re-election chances, to regional economic development and IRBs/ITBs, to domestic and international pressures. $^{34}$

In his examination of the CP-140 Long Range Patrol Aircraft and Leopard I tank decisions, Robert Adams found that project delays with the former were the result of cabinet disagreement, especially from the finance minister and treasury board president, over costs during a time of fiscal restraint. Political support, including from the opposition, for the LRPA eventually came when the proposed offsets package proved enticing. The Leopard I purchase highlights cabinet's importance even when external factors are the impetus for the procurement. In the Leopard I case, Canada's European Community allies pressed Ottawa to maintain its mechanized brigade in West Germany in the face of Pierre Trudeau's cutbacks to the CAF's NATO contribution in 1968-69 as well as the official White Paper, Defence in the 70s, call for not replacing the army's aging Centurion tanks. ${ }^{35}$

Michael Tucker, in his book on Canadian foreign policy, also covers the acquisition of the CP-140 Aurora patrol aircraft. Tucker similarly applies the rational-model and finds it ineffective. In the case of the Aurora, the government was less interested in alliance considerations (the concern of the CAF) than it was in getting benefits for Canadian industry. For the Aurora, there was no single minister responsible for its purchase, each department - Industry (now ISEDC), Supply and Services (now PSPC), and Defence - approached the project through

\footnotetext{
${ }^{34}$ William B. Fox, "The Politics of Procurement: The Low Level Air Defence Decision of 1986," in Canada's Defence Industrial Base: The Political Economy of Preparedness and Procurement, ed. David G. Haglund (Kingston: Ronald P. Frye and Company, 1988).

${ }^{35}$ Robert Michael Adams, "Procurement Maketh Policy: A Case Study of The CP-140 Aurora and The Leopard I" (MA Dissertation, McMaster University, 1980), 113, 117, 126, 148, 157, 161, 165.
} 
the lens of their own mandate which led to clashes and delays. Cabinet meanwhile was focused solely on keeping the cost low while maximizing offsets. ${ }^{36}$ Likewise, with the famed Avro 'Arrow', Donald C. Story and Russell Isinger conclude that strategic considerations were of little importance to the project's decision-making. Military brass were more concerned with having the best jet possible - regardless of whether it met the capability requirements for the air force while the cabinet supported it as long as it did not threaten the treasury. When it became a fiscal burden the project was axed. ${ }^{37}$

Kim Richard Nossal picks up from his examination of the CF-18 purchase in 1980 (see below) to an analysis of the Conservative's attempt to acquire the F-35. In 1981, he and Michael M. Atkinson had argued that the CF-18 acquisition was the model of a successful procurement because cabinet imposed constraints on the bureaucracy by specifying the winning aircraft's requirements, capping the budget, and creating an administrative structure independent of other departments. ${ }^{38}$ In the case of the F-35, Nossal suspects that there are three interrelated reasons for why procurement under the Harper government became mired in delays: (1) upon coming to power in 2006 they lacked knowledge in defence policy; (2) the cabinet lacked experience in handling large-scale military procurements; (3) and, consequently, were too trusting of the CAF and DND. In short, the Harper Conservatives were more interested in using defence as a way to

\footnotetext{
${ }^{36}$ Michael Tucker, Canadian Foreign Policy: Contemporary Issues and Themes (Toronto: McGraw-Hill Ryerson Ltd., 1980), 153, 155-156, 160, 163.

${ }^{37}$ Donald C. Story and Russell Isinger, "The Origins of the Cancellation of the Canada's Avro CF-105 Arrow Fighter Program: A Failure of Strategy," The Journal of Strategic Studies 30, no. 6 (2007): 1047-1048.

${ }^{38}$ Michael M. Atkinson and Kim Richard Nossal, "Bureaucratic Politics and the New Fighter Aircraft Decisions", Canadian Public Administration 24:4 (Winter 1981): 531-62.
} 
distinguish themselves from the Liberals. The culmination of these factors meant that, at least initially, there was a lack of political control over the bureaucracy which contributed to delays. ${ }^{39}$

Canada's procurement system has been the subject of review by both Parliamentary Standing Committees, the Auditor General, the Parliamentary Budget Officer and DND itself. A 2000 study by the Standing Committee on National Defence and Veterans Affairs concluded that two problems dominate defence procurement: a lack of stable funding and proper management resources. The lack of a single accountable minister for procurement and Ottawa's longstanding treatment of defence expenditures as a means to promote non-defence objectives were similarly seen as undermining the efficacy and efficiency of the procurement system. ${ }^{40}$ A 2005 report by the same Committee into the acquisition of four British submarines in 1998 determined that delays were the result of the Prime minister not wanting to approve the purchase in the face of fiscal restraint, competing demands on the treasury, and a possible negative public reaction. The Committee also found that because DND did not follow proper risk analysis procedures they underestimated how much time and money would be required to make the subs serviceable. ${ }^{41} \mathrm{~A}$ 2008 report by the same Committee recommended that a separate procurement agency and minister be established; that human resource deficiencies - particularly in training - be addressed; and that more off-the-shelf purchases be considered..$^{42}$ Likewise, a 2017 report by the Senate Standing Committee on National Security and Defence concluded that there are "too

\footnotetext{
${ }^{39}$ Kim Richard Nossal, "Late Learners: Canada, the F-35, and lessons from the New Fighter Aircraft program," International Journal 68, no. 1 (2012-13): 171-173, 180-183.

${ }^{40}$ Canada. House of Commons. Standing Committee on National Defence and Veterans Affairs, Procurement Study, 2nd Session, 36th Parliament, Report no. 3, June 24, 2000.

${ }^{41}$ Canada. House of Commons. Standing Committee on National Defence and Veterans Affairs, Procurement of Canada's Victoria Class Submarines, 1st Session, 38th Parliament, Report no. 1, April 2005.

${ }^{42}$ Standing Committee on National Defence. Procurement and Associated Processes, $39^{\text {th }}$ Parliament, $2^{\text {nd }}$ Session, 2008.
} 
many players" in the procurement system with "too little focus on advancing major procurements on time and on budget"; this has contributed to a situation in which there are "too many governments passing the buck". The Senate Committee's solution for what they termed as "the second biggest problem" at DND, after inadequate funding, was mostly premised on strengthening the political executive's role in procurement, chiefly by having the minister of national defence receive a new mandate to procure military equipment "in a timely manner", oversee defence-related industrial benefits, and streamline approval processes. Enabling this mandate would be the transfer of "all defence and Coast Guard" procurement responsibilities from PWGSC to DND, and the creation of "a major military procurement agency" within DND. The minister should also appoint a "lead negotiator and interlocutor for each procurement project valued over $\$ 1$ billion dollars and assign responsibility and accountability". ${ }^{43}$

Similarly, a series of reports in 1987, 1992, and 1998 by the Auditor General attributed delays to managerial burnout and the understaffing of project offices. A lack of policy guidance and an emphasis on offsets was seen as further hampering the procurement process. ${ }^{44}$ While noting again the shortage of procurement staff and project managers, the Auditor General's examination of the CF-18 upgrade project in the early-2000s found the multi-billion dollar upgrade was performed without an analysis; and that the final decision to upgrade 80 jets was done purely on the basis of what cabinet was willing to financially allow. ${ }^{45}$

\footnotetext{
${ }^{43}$ Canada. Senate. Standing Committee on National Security and Defence. Military Underfunded: The Walk Must Match the Talk, April 2017, 33-36.

${ }^{44}$ Canada. Office of the Auditor General of Canada. Chapter 9: National Defence. Ottawa: 1987.; Canada. Office of the Auditor General of Canada. Chapter 17: National Defence. Ottawa: 1992; Canada. Office of the Auditor General of Canada. Chapter 4: National Defence: Equipping and Modernizing the Canadian Forces. Ottawa: 1998.

${ }^{45}$ Canada. Office of the Auditor General of Canada. Chapter 3: Upgrading the CF-18 Fighter Aircraft. Ottawa: 2004.
} 
Due to the increase in procurement projects initiated under the Harper government, the Auditor General reviewed multiple MCPs. A 2009 report critiqued the rush of Urgent Operational Requirement (UOR) purchases for the Canadian Army in Afghanistan in 2005-2008 as failing to comply with government approval policies. Consequently, project budgets were not fully aligned with the CAF's own stated needs, meaning that fleets of new vehicles like the Leopard II tank or the RG-31 mine resistant armoured vehicle, were acquired in insufficient number. UOR purchases may have delivered the equipment in the field more quickly but it was at the expense of proper testing and evaluation necessary for detecting possible design or safety flaws. ${ }^{46}$ A 2010 report into the much delayed Maritime Helicopter Project and, to a lesser extent, the Medium-Heavy Lift Helicopter project, determined that extensive modifications, or 'Canadianization', to existing aircraft designs in effect turned what were viewed as off-the-shelf helicopters into developmental projects that raised costs and prolonged acquisition timelines. ${ }^{47}$

Within DND, a 2003 ministerial advisory report on defence administration attributed inefficient processes to a culture of low risk tolerance. Poor allocation of human and financial resources, the result of an absence of project prioritization, was equally a culprit in contributing to a slow procurement process. Government White Papers, which could assist in prioritizing procurement projects, frequently become outdated with the political executive ceasing to provide clear direction to the CAF. Without a clear policy direction, procurement decisions are "bottom up' driven, a situation that fosters resource competition between the armed services. This creates a situation where "there are too many projects chasing too few dollars" leaving "scarce" project

\footnotetext{
${ }^{46}$ Canada. Office of the Auditor General of Canada. Chapter 5: Acquiring Military Vehicles for Use in Afghanistan. Ottawa: 2009, 2-3, 20, 23.

${ }^{47}$ Canada. Office of the Auditor General of Canada. Chapter 6: Acquisition of Military Helicopters. Ottawa: 2010, $15,21$.
} 
management staff tied up rather than being "devoted only to higher priority projects". The staffing situation is further compounded by the "relatively high 'churn rate' of senior military officers and civilian executives at the Director level and above", with most officials spending only a few years in a rank before their next promotion or retirement. This makes it hard to generate institutional knowledge and experience in complex procurement within DND. ${ }^{48}$ To no one's surprise, the report found the "Government's procurement process...slow and arduous" and "overburdened with reviews and duplication of efforts". Due to the complexity, cost, and quantities of equipment purchased it was recommended that "a dedicated procurement agency or division" be established as the split between DND and PSPC remained a poor use of government resources. $^{49}$

A 2006 review of the military procurement process, led by DND's own internal auditor, the Chief Review Services, remarked that a culture shift was required because of armed service parochialism and a narrow, platform-centric view towards selecting new equipment (as opposed to looking at capabilities). Like the 2003 report, the CRS recommended that duplications between DND and PWGSC be resolved; that ADM (Mat) be established as separate procurement agency; and that the armed service chiefs, the ranking senior officers in what are now the Royal Canadian Navy, Canadian Army and Royal Canadian Air Force, be placed in charge of project management instead of DND civilians; such a change would create a point of accountability by forcing the service chiefs to align their requirements designing duties with "executing the major capital projects acquisition to prescribed timelines and costs". ${ }^{50}$ Five years later, in an attempt to identify cost-savings and improve organizational effectiveness amid government-wide fiscal

\footnotetext{
${ }^{48}$ Canada. Department of National Defence. Report to the Minister of National Defence, 16, 17, $25,33$.

49 Ibid., 28.

${ }^{50}$ Canada. Department of National Defence, Perspectives, i, 13-14.
} 
restraint DND undertook another review. Under the auspices of Lieutenant-General Andrew Leslie the review's report, the Report on Transformation, concluded that DND's Materiel division, ADM (Mat), had become reliant on contractors at the expense of developing its own internal, human resource capacity in procurement. Between 2003-2004 and 2009-2010, ADM (Mat) had a 50 percent real growth increase in funding but only a four percent growth in personnel. Because of personnel shortages and the rapid growth in procurement projects over the course of the Paul Martin and early Stephen Harper governments, ADM (Mat) experienced "production and capacity challenges" that left hundreds of millions of dollars unspent; a fact compounded by DND/CAF's “many layers of complex bureaucratic processes that are counterproductive to efficiency and effectiveness". 51

Finally, as noted in the introduction, Canada is not the only country to have procurement problems. According to Theo Farrell, in the United States the armed services are responsible for much of the financial waste and delays in procurement. Each armed service engages in political gamesmanship, manipulating the procurement system so as to "maximize political support for their own weapons programmes". In his analysis of three major procurement projects from the 1970s and 1980s, Farrell found that the armed services wrote requirements in a way to "exaggerate" the need for weapons systems and to build political support for them, engaged in 'gold-plating' without regard to costs, and rushed projects into production in order to reduce the chance of cancellation because of the political and financial "sunk cost dynamic". The ripple effect of this approach in the long-run, however, generated delays as project requirements were never properly validated and 'sticker shock' from mounting costs led, at times, to political push-

\footnotetext{
${ }^{51}$ Leslie, Lieutenant General Andrew. Report on Transformation 2011. Ottawa: Department of National Defence, 2011, 30-32.
} 
back and outright cancellation. Like some of the recommendations for addressing Canadian procurement woes, Farrell's two solutions are to use financial constraints too incentivize cost ceilings on projects and to develop internal procurement expertise in the Department of Defense..$^{52}$

With a Westminster parliamentary system and similar geopolitical reality, a more fitting Canadian comparison is found in Peter Greener's, The Politics of New Zealand Defence Acquisition Decision Making. Greener argues that New Zealand's defence procurement projects are influenced by external factors - particularly its alliance with Australia - up until the point where cabinet has to make a decision on whether to initiate a project and/or approve the purchase of a project. Consequently, in New Zealand, "timing is most critical both early in the process and ultimately when a decision on choice is being made". Greener finds that bureaucratic and government politics are a constant throughout the procurement process especially when it comes to deciding on a specific platform or upgrade. Hence, it is not uncommon for an armed service to leak information to generate support for a purchase as the New Zealand Army did with a (Canadian-made) Light Armoured Vehicle contract in 1997-2000. However, in New Zealand individuals are critical to stopping or starting projects. For example, the Prime minister is seen as a lever to be used by defence ministers to bring cabinet and caucus colleagues onside in favour of a specific procurement project while treasury ministers frequently battle with defence ministers over funding. ${ }^{53}$

\footnotetext{
52 Farrell, Theo. "Waste in Weapons Acquisition: How the Americans Do It All Wrong." Contemporary Security Policy 16, No. 2 (1995): 192, 210, 212-214.

${ }^{53}$ Greener, Peter. Timing is Everything: The Politics of New Zealand Defence Acquisition Decision Making. Canberra: Australia National University Press, 2009, 151-154.
} 


\section{Literature Gap}

There are two key gaps in the Canadian defence procurement literature: the lack of both a systematic analysis in defence procurement, a point noted by other scholars, and an analysis of the role the political executive plays in the defence procurement process. ${ }^{54}$ This dissertation seeks to corrects this. The literature points to the role that the political executive plays in contributing to procurement delays but this is often portrayed as being ancillary to the internal debates occurring within DND, between the military and bureaucracy, and between DND and other departments, such as Finance, PWGSC, Treasury Board Secretariat (TBS), and IC. At the same time, specific references linking the actions of the political executive with delays include: Williams's and Sloan's acknowledgment of cabinet ministers not understanding defence procurement costing and budgetary principles; government and Parliamentary reports recognizing the impact of unclear political direction on what the military's priorities should be; a downplaying of costs by the military in order to convince ministers to support their favoured acquisitions; Middlemiss's statement that defence budgets are constantly at the mercy of political domestic concerns and thus subject to fluctuation; Plamondon's view that delays are the result of partisan political decisions; that procurement decisions are the result of elite preferences (Arsenault); and Nossal's suggestion that, at least in the case of the Harper Conservatives, the political executive lacked experience in complex defence acquisitions and were too trusting of the CAF and DND. All these critiques point to the role that the political executive plays in procurement delays but yet they - the prime minister, cabinet and staffers - have never been subject to a systematic, comparative examination. Moreover, the existing literature's emphasis

\footnotetext{
${ }^{54}$ Davies, "Understanding Defence Procurement"; Nossal, Charlie Foxtrot, 122; Plamondon, The Politics of Procurement, 16.
} 
on the internal squabbles within and between departments remains too narrow when there clearly is room for analyzing any political executive contribution to procurement delays.

Hence, the identified gap in the literature begs this research question: how can we account for delays in Canada's defence procurement program? This thesis argues that the political executive, comprising the prime minister, cabinet, and staffers, are central to understanding why there are delays in Canada's defence procurement program. Therefore, the political executive will be the independent variable while procurement delays will be treated as the dependent variable. Delays are those instances in which a project, once officially identified by the DND as a procurement priority, fails to either go before cabinet for Effective Project Approval (EPA) or is denied approval at the EPA stage (see Chapter Two for a more detailed overview of the defence procurement process). The focus will be on endogenous delays as these can better account for the role cabinet can play in impeding the procurement process. Three other exogenous explanations - the inter-departmental defence procurement bureaucracy and external factors beyond the federal government's control (alliances and the Afghanistan war, and the defence industry) - will be treated as independent variables in each chapter to fully evaluate whether the core argument is sufficient enough of an explanation in explaining procurement delays.

\section{Theoretical Framework}

This dissertation relies on the bureaucratic politics model. Although historical institutionalism could also be an appropriate framework it fails to capture the role that actors play in shaping 
defence policy. ${ }^{55}$ Bureaucratic politics traces its origins to Graham Allison's ground-breaking study, Essence of Decision. Allison critiqued the (still) dominant Rational-Actor approach to international relations, which he termed Model I. Model I, embodied in such theories as realism and liberalism, treats governments as black boxes, ignoring the idea that outcomes are the result of "innumerable and often conflicting smaller actions by individuals and various levels of organizations". ${ }^{56}$

In contrast, he proposes two additional models: organizational politics (Model II) and governmental politics (Model III). Both Models operate in tandem with one another. Model II is derived from organizational theory, which emphasizes the impact of "distinctive logic capacities, culture, and procedures of large organizations" on shaping policy. Model II frames its analysis on the following question: "from what organizational context, pressures, and procedures did this decision emerge?". In short, it looks at an organization's raison d'être and how past decisions constrain the options of new policy-makers. From the Canadian experience, organizations provide the setting and rules "under which individuals decide what, when, and how information is aggregated into collective decisions and who participates in making the decision". ${ }^{57}$ With procurement, DND is focused on the technical aspect of military capabilities, PWGSC on ensuring the integrity of the contracting process, IC on maximizing offsets, and the Treasury Board Secretariat of Canada, alongside Finance Canada, in containing costs. The political executive, meanwhile, aims to not suffer embarrassment and electoral punishment.

\footnotetext{
${ }^{55}$ For an institutionalist examination of Canadian defence see Fitzsimmons, Daniel. "Transformation in the Canadian Forces: A Sociological Institutionalist Approach to Change in the CF from Peacekeeper to War Fighter." Innovations: A Journal of Politics 8 (2009), 16-33.

${ }^{56}$ Allison, Graham and Philip Zelikow. Essence of Decision: Explaining the Cuban Missile Crisis (2 ed.) (New York: Addison Wesley Longman, 1999), 7, 10, 5-6.

${ }^{57}$ Savoie, Donald J. Power: Where Is It? Montreal-Kingston: McGill-Queen's University Press, 2010, 232.
} 
In conjunction with Model II, Model III examines the bargaining games that occur among players in government. Model III's predictions are generated by "identifying the game in which an issue will arise, relevant players, and their relative power and bargaining skill. ${ }^{58}$ It is the "pulling and hauling" between actors that results in policy outcomes, often in the form of compromises that do not resemble the initial proposals. ${ }^{59}$ In this sense, a procurement delay is an outcome that did not reflect an MCP when it was formally identified. Actors' interests, are determined by "parochial priorities and perceptions" associated with the position the player occupies. These priorities are filtered through "baggage", including sensitivities to "certain issues, commitments to various projects, and personal standing with and debts to groups in the society. ${ }^{60}$ From Model III, three hypotheses can be discerned: (1) actors' policy preferences can be predicted from their position within government; (2) the stronger an actor's bargaining advantages, the greater the degree of his/her influence in the policy-making process; (3) and, the greater the prevalence of political pulling and hauling among actors, the greater the likelihood of the final decision outcome being an example of a political compromise. ${ }^{61}$

The strengths of adopting a Model III-based analysis are threefold. First, it allows for the evaluation of actions by individuals or institutions; second, it offers a prescription of what is to be done; and, lastly, it illustrates how the management of a sequence of actions, by an individual or group, are used to achieve a chosen objective. ${ }^{62}$ Model III has been applied successfully to other case studies, ranging from how each branch of the US armed services prepared for the

\footnotetext{
${ }^{58}$ Allison and Zelikow, Essence of Decision, 5-6.

${ }^{59}$ Edward Rhodes, "Do Bureaucratic Politics Matter? Some Disconfirming Findings from the Case of the U.S. Navy," World Politics 47, no. 1 (1994): 7.

${ }^{60}$ Allison and Zelikow, Essence of Decision, 295-298.

${ }^{61}$ Kevin Marsh, “Obama's Surge: A Bureaucratic Politics Analysis of the Decision to Order a Troop Surge in the Afghanistan War," Foreign Policy Analysis 10, no. 3 (2014): 269.

${ }^{62}$ Allison and Zelikow, Essence of Decision, 9.
} 
1991 Gulf War to President Obama's decision to launch a 'surge' of troops in Afghanistan in $2009 .{ }^{63}$ Given its prominence Model III has been the subject of some pointed criticisms, particularly that it is poor at explaining decisions made during crises. ${ }^{64}$ Still, notwithstanding these criticisms, Allison's critics "rarely propose a viable solution to alleviate the problems they point out". 65

Bureaucratic politics is most applicable to the study of Canadian defence procurement. Kim Richard Nossal has long documented the weakness of rational models in explaining Canadian defence outcomes. He argues that Canadian governments promote the notion that defence policy operates along rational parameters (e.g. White Papers) but the reality is different. Instead, defence policy is best characterized as being 'non-rational', as opposed to irrational. Manifestations of this non-rational behaviour can be seen in defence procurement where the CAF's military needs operate in tension and are frequently made subservient to non-military interests, such as regional job creation and industrial offsets. Non-rationality is similarly illustrated when attempts are made to close Canadian Forces Bases (CFBs). During fiscal crunches, the CAF and DND turn to advocating closing bases as a way to generate savings but

\footnotetext{
${ }^{63}$ Kathleen Conley, "Campaigning for Change: Organizational Processes, Governmental Politics and the Revolution in Military Affairs," Airpower Journal (Fall 1998): 68; Marsh, "Obama's Surge: A Bureaucratic Politics Analysis of the Decision to Order a Troop Surge in the Afghanistan War," 282.

${ }^{64}$ For examples, see Stephen D. Krasner, “Are Bureaucracies Important? (Or Allison Wonderland)," Foreign Policy (Summer 1972): 160, 179. David A. Welch, "The Organizational Process and Bureaucratic Politics Paradigms: Retrospect and Prospect," International Security 17, no 2 (1992): 114-115, 121, 132, 137-138. Rhodes, "Do Bureaucratic Politics Matter? Some Disconfirming Findings from the Case of the U.S. Navy", 39-41; Martin A. Smith, "US bureaucratic politics and the decision to invade Iraq," Contemporary Politics 14, no 1 (2008): 103; Nelson Michaud, "Bureaucratic Politics and the Shaping of Policies: Can We Measure Pulling and Hauling Games?" Canadian Journal of Political Science 35.2 (2002): 271.

${ }^{65}$ Welch, "The Organizational Process and Bureaucratic Politics Paradigms: Retrospect and Prospect," 137-138; Michaud, "Bureaucratic Politics and the Shaping of Policies: Can We Measure Pulling and Hauling Games?," 271.
} 
are overruled by cabinet ministers and MPs who are keen on keeping CFBs open in economically depressed regions (e.g. CFB Greenwood, Nova Scotia). ${ }^{66}$

This is not to say that there have not been attempts to structure defence-policy making along rational lines. The establishment of a National Defence Headquarters in 1972, which combined the headquarter staffs of the CAF with DND, was an attempt to create a unified rational decision-making process. However, armed service rivalries over scarce resources persist and power remains concentrated with political actors in the centre. NDHQ is also beset by differing organizational cultures between the CAF and DND. The former is underpinned by the "principles of war and command" while the latter is defined by norms of public management. Each organization approaches defence procurement with different values, goals, and perspectives. Of note, Bland in his 1997 assessment of NDHQ found that personalities mattered more than formal policy process structures given that a Chief of Defence Staff and a deputy minister, for example, can dominate the institution. As Canadian governments rarely provide political direction on defence such actors can fill the void with their own interests. ${ }^{67}$

Consequently, Canadian defence policy is best understood as being shaped by: individuals and their preferences, interests, and preferences; bureaucratic and policy processes; and wide domestic and international environments. The sum total of these variables determines defence outcomes ${ }^{68}$ Fortunately, the key obstacle to applying Allison's Model III to Canada, given its American-centric foundation, has been overcome. Contrary to its southern neighbour,

\footnotetext{
${ }^{66}$ Kim Richard Nossal, "Rationality and non-rationality in Canadian defence policy," in Canada's International Security Policy, eds. David B. Dewitt and David Leyton-Brown (Scarborough: Prentice-Hall Canada, 1995), 351352, 359-360.

${ }^{67}$ Morton, Desmond. A Military History of Canada. (Toronto: McClelland \& Stewart Ltd., 2007), 259-261; Douglas L. Bland. National Defence Headquarters: Centre for Decision (Ottawa: Minister of Public Works and Government Services Canada, 1997), 38, 41.

${ }^{68}$ Middlemiss and Sokolsky, Decisions and Determinants, 4.
} 
Canada's policy making system is much more centralized and involves far fewer players. ${ }^{69}$ Nossal found that the Canadian policy-making system was suitable to the Model, keeping in mind that in a parliamentary system both cabinet and the need for centralized policy coordination can often control and settle serious bureaucratic conflicts that would otherwise occur in a separation-of-powers system. In the Canadian context, cabinet ministers are as important to the paradigm as bureaucrats: "securing cabinet agreement, implementing a cabinet directive are all outcomes of "politics"" ${ }^{70}$ While cabinet decision-making is secret its outcomes, particularly in defence, take the form of procurement decisions and budgets and thus constitute observable behaviour. $^{71}$

In Atkinson's and Nossal's study of the 1980 CF-18 procurement they found that there was less conflict than the Model would suggest. The chief reason for co-operation among senior bureaucrats, in different departments was that cabinet had imposed constraints on the bureaucracy. When conflict did occur, it was only when "cabinet direction was both vague and ambiguous". ${ }^{72}$ Additional Model III Canadian case studies covering the 1987 defence White Paper and the 2005 International Policy Statement, respectively, have borne this analysis out. ${ }^{73}$

\footnotetext{
${ }^{69}$ Ibid., 4.

${ }^{70}$ Kim Richard Nossal, "Allison through the (Ottawa) Looking Glass: bureaucratic politics and foreign policy in a parliamentary system," Canadian Public Administration 22, no. 4 (1979): 613, 616.

${ }^{71}$ Middlemiss and Sokolsky, Decisions and Determinants, 4.

72 Michael M. Atkinson and Kim Richard Nossal, "Bureaucratic politics and the new fighter aircraft decision," Canadian Public Administration 24, no. 4 (1981): 534-35, 562.

${ }^{73}$ Michaud, "Bureaucratic Politics and the Shaping of Policies: Can We Measure Pulling and Hauling Games?", 278, 283; Marie-Eve Desrosiers and Philippe Lagassé, "Canada and the Bureaucratic Politics of State Fragility," Diplomacy \& Statecraft 20 (2009): 660-61, 669, 673.
} 


\section{Methodology}

In assessing whether the political executive has contributed to delays in Canada's procurement system this thesis examines four MCPs: Joint Support Ships (JSS), Medium Support Vehicle System - Standard Military Pattern (SMP), Fixed-Wing Search and Rescue (FWSAR), and the Halifax Class Modernization/Frigate Life Extension (HCM/FELEX). The first three each represents a project specific to an armed service - navy, army, air force - that missed their original milestones and became characterized by multi-year delays stretching from seven years (SMP) to fourteen (FWSAR). The fourth project, the HCM/FELEX, is thought to be a procurement success and is used to test the validity of the dissertation's hypothesis in the affirmative. The benefit of selecting these four MCPs is that they all trace their beginnings to the Chrétien and Martin Liberal governments and thus offer another comparative lens upon which to assess the role of the political executive apart from the Harper Conservative government which recommitted to all four projects between 2006 and 2008. More blatant examples of political executive interference in defence procurement, like the Maritime Helicopter Project and the Future Fighter Capability Project to replace the CF-18, are intentionally avoided because they are both well known and have been subject to a number of scholarly analyses. ${ }^{74}$

Consequently, in undertaking this assessment each of the four case studies is broken down into three separate analytical sections. Using the defence procurement process outlined in Chapter Two, the first section tests the thesis's hypothesis by tracing the political executive's

\footnotetext{
${ }^{74}$ For example, Plamondon's The Politics of Procurement covered extensively the attempt by successive governments since the mid-1970s to replace the CH-124 'Sea King' helicopters. For the CF-18s, see Richard Shimooka. The Fourth Dimension: The F-35 Program, Defence Procurement, and the Conservative Government, 2006-2015 (Ottawa: Conference of Defence Associations Institute, 2016). Also, International Journal dedicated an entire issue to the Harper government's F-35 debacle, albeit from a comparative viewpoint: International Journal 68 , no.1 (2013).
} 
involvement in each respective procurement project with an emphasis placed on those points where the political executive made a decision that affected the project's status. For example, this could be where the political executive (in the form of Treasury Board, for example) approved funding that allowed for the set-up of a project management office, like at the Preliminary Project Approval stage, or stopped a project altogether because of pressure from the domestic defence industry over industrial benefits concerns. Hence, the focus in this section will be on evaluating whether the political executive prolonged a project's acquisition due to political calculations: for example, financial costs, regional economic development, or political sensitivity. The second section analyzes each case study project from the perspective of the three exogenous independent variables; chiefly, the inter-departmental relationship between the three primary procurement departments (PWGSC, DND, IC) - referred to as the 'Defence Procurement Bureaucracy' in the dissertation; the role of the defence industry (e.g. lobbying) and the defence industry marketplace; and the influence of Canada's alliances and the impact of the Afghanistan war. The goal of this section is to assess whether any of these independent variables can help better explain why delays occurred than the hypothesis. The third and final section evaluates the first two sections to determine whether the dissertation's hypothesis is valid.

For a methodological framework, this thesis utilizes both the case study model and process-tracing. Case studies allow for an "intensive study" that is generalizable across a larger set of units. As Jack S. Levy notes, by taking such a "detailed examination of an aspect of a historical episode" a hypothesis can be tested more fully. Moreover, multiple cases allow for the minimization of bias by testing a hypothesis against alternative interpretations. ${ }^{75}$ All four case

\footnotetext{
75 Jack S. Levy, "Case Studies: Types, Designs, and Logics of Inference," Conflict Management and Peace Science 25 (2008): 3-9.
} 
studies trace their beginnings under the Liberal governments of Jean Chrétien (1993-2003) and Paul Martin (2003-2006), respectively, however, it is within the 2006-2015 time frame, when Stephen Harper's Conservative government held office, that each project received cabinet approval to proceed along the procurement process toward contract award and final acquisition (see Chapter Two for a greater overview of the procurement process). It was also the Harper government which made defence and the CAF a key part of their brand identity and early electoral platforms. Between 2006 and 2008, the Harper government embarked on the largest military build-up since the Korean War before cutting and deferring billions in defence spending between 2010 and $2014 .^{76}$ How and why a government so committed to defence - a rarity in Canadian politics - ended up with such major procurement problems is in part an added nuance to assessing the political executive's role in possibly causing procurement delays. Given this, this dissertation can control for the number of actors occupying key positions in the defence procurement process, and external pressures such as the Afghanistan war or the 2008-09 global financial crisis. Finally, as Gerring states, because a case study is a form of defining cases and not analyzing them, this dissertation relies upon process-tracing for its analyses. Process-tracing allows the researcher to follow the "trajectories of change and causation" in each MCP and to evaluate my hypothesis. ${ }^{77}$ More to the point, looking at specific snapshots in time allow for a more complete and comparative examination of decision-making at the individual and organizational levels, thereby offering a sound basis in which to utilize the Bureaucratic politics

\footnotetext{
${ }^{76}$ See: Peter Jones and Philippe Lagassé, "Rhetoric versus reality: Canadian defence planning in a time of austerity," Defense \& Security Analysis 28, no. 2 (2012): 140-151; Andrew Richter, "A Defense Renaissance? The Canadian Conservative Government and the Military," American Review of Canadian Studies 43, No. 3 (2013): 424-450; David Perry, “A Return to Realism: Canadian Defence Policy after the Great Recession," Defence Studies 13, No. 3 (2013): 338-360.

${ }^{77}$ John Gerring, "What is a Case Study and What Is It Good for?," American Political Science Review 98, No. 2 (2004): 341-342; David Collier, "Understanding Process Tracing," PS: Political Science and Politics 44, No. 4 (2011): 823-827.
} 
model. References in the concluding chapter are made to how other Westminster parliamentary systems, like Australia and New Zealand, encountered similar procurement woes and the degree to which their respective political executives were responsible for delays, and why.

This dissertation's primary sources draw on government and parliamentary documents including federal budgets, defence policy statements like the Canada First Defence Strategy, the Office of the Auditor General, the Parliamentary Budget Officer, and the respective Senate and House standing committees on national defence, including testimony from senior military and bureaucratic officials in front of these committees. DND's own documentation has proven to be a wealth of primary source information. Each year the department produced a Report on Plans and Priorities and Departmental Performance Review (beginning in 2017, both have been merged into a new document, Departmental Plans) for the Treasury Board Secretariat. Included in these reports was a 'Status Report on Transformational and Major Crown Projects'; both reports outlined (and continue to outline in their new guise) the purpose and progress being made on defence MCPs, providing explanations as to any variance. The department's own internal auditor, the Chief Review Services (CRS), has made available its reports into all four of the MCPs examined in this dissertation. The CRS provides an in-depth, departmental process analysis on the problems and progress being made on a given MCP.

The fact that these projects are still ongoing has created limitations in being able to draw on a wider breadth of government documentation (e.g. ministerial briefing papers) that currently remain classified or are covered by cabinet confidences. A historical book, like Plamondon's review of the Sea King replacement project noted above in the literature review, highlights the strengths of examining a subject after enough time has passed in which government materials become either declassified and/or reallocated to archives. This dissertation 
partly addresses this limitation through a series of elite-level interviews with twenty-three former and current key players from the senior political, bureaucratic, and military levels of the procurement process during the time period of 2002 to 2015. Owing to the sensitive nature of the topic most interviewees asked to remain confidential. In some cases, senior officials were still serving in government capacities and declined to participate in the project. Former cabinet ministers from the Harper government were approached indirectly through intermediaries for interviews, however, none ever responded. Consequently, the author was unable to discern why ministers were not interested in taking part in the project. The author was fortunate enough to have worked as a policy advisor and political staffer to Canada's defence and veteran affairs ministers in the past; this allowed him to establish relationships with government officials and facilitated his ability to connect and undertake the requisite interviews. These interviews were either conducted over the phone and by email, from the author's home in Prince Edward Island, or in-person, in Ottawa, between September 2016 and February 2017. While there is always the possibility of interviewees' opinions working at cross-purposes, a reliance on information gleamed from government primary sources, media coverage, think-tank and scholarly publications have proved apt in accounting for discrepancies.

Finally, this dissertation represents an important contribution to the literature on defence procurement in Canada by reorienting the discussion away from its focus on explaining procurement delays by way of internal bureaucratic and military dynamics. As it stands now, the role of the political executive in defence procurement has been treated peripherally by much of the literature. This dissertation bridges this gap. 


\section{Chapter Outline}

This dissertation comprises seven chapters, four of which are procurement case studies from 2006 to 2015 . Chapter Two will provide an overview of the defence procurement process and the Canadian defence policy-making environment. The focus here will be on explaining the major stages and organizations involved in initiating the procurement process for acquiring a MCP. The introduction of the Defence Procurement Strategy (DPS) in 2014 and the election of the Liberal government under Justin Trudeau in 2015 (both discussed in Chapter Seven) have seen new processes and administrative structures added to the defence procurement system. However, none of the MCPs assessed in this thesis are subject to these changes as they only apply to those projects started after 2014 .

Importantly, though, the DPS did not alter the basic structure of the procurement process and thus the explanation provided in Chapter Two remains pertinent. ${ }^{78}$ Chapter Two also features a discussion on Canada's wider defence policy-making environment. This section of the chapter situates the procurement process within the context of competing influences from the domestic and international political environments, and from actors and institutions, thus providing a larger context from which the case study analyses can occur.

The first of the case studies, Chapter Three, examines the JSS project. Originally identified as an MCP in 2004 during the Paul Martin government, the JSS was intended as a 'one-of-a-kind' ship capable of transporting troops and sustaining other naval ships at sea. A series of stops and starts has seen this project scaled back both in scope and numbers, from three ships to two, with a delivery date in 2021-2022. The failure of the first JSS Request for Proposal

\footnotetext{
${ }^{78}$ Canada. Public Services and Procurement Canada. Defence Procurement Strategy, accessed September 23, 2016. https://www.tpsgc-pwgsc.gc.ca/app-acq/amd-dp/samd-dps/index-eng.html.
} 
(RFP) in 2008 became the impetus for the Harper government's 2010 National Shipbuilding Procurement Strategy (since shortened to, 'National Shipbuilding Strategy'), an attempt to kick start the shipbuilding industry and bring a degree of rationality to naval procurement. Delays in the JSS have also seen the executive turn towards approving expensive interim solutions, including retrofitting a German cargo ship in Quebec, to maintain the RCN's ability to sustain its ships at sea.

Chapter Four covers the Medium Support Vehicle System project, specifically the Standard Military Pattern component of the project (SMP). The SMP was the last in a series of attempts to replace the Canadian Army's rusted out Medium Logistics Vehicle Wheeled (MLVW) trucks. After several failed sole-source attempts under the Liberals, the MLVW replacement project was rechristened as the SMP by the Harper government in June 2006. Specification alterations and corresponding cost increases in 2008-2009 contributed to an outright cancellation of the RFP in 2012. A new RFP and restart led to a contract award in 2015 with deliveries expected in 2017 - seven years beyond the original planned date. The SMP case study illustrates how an ostensibly less complex project - buying logistics trucks for the army became one of the government's most protracted and overdue MCPs. As of 2017 the SMP remains shrouded in legal action following the successful appeal of a losing competitor to the Canadian International Trade Tribunal (CITT).

The Fixed-Wing Search and Rescue aircraft is the subject of Chapter Five. Long said to be a federal 'priority' since the Chrétien government, the FWSAR was designed to replace the five-decade old CC-130H 'Hercules' and CC-115 'Buffalo' search and rescue aircraft. The Harper government committed itself to the FWSAR during the 2006 campaign but by 2009 the project became mired in disputes as allegations of requirements 'rigging' by RCAF personnel in 
favour of one particular aircraft, Italian firm Alenia's C-27J, led to an external review and a project restart in 2010. The FWSAR contract was finally awarded to European manufacturer Airbus Defence and Space in December 2016 for sixteen aircraft. Deliveries are expected between 2019-2022. ${ }^{79}$ The time spent on the FWSAR, from project identification to implementation of contract, was fourteen years. And, like the SMP, it too faced legal challenges at the CITT from a losing competitor.

The final case study, Chapter Six, concerns the Halifax Class Modernization and Frigate Life Extension (HCM/FELEX) project. A $\$ 4.3$ billion project, the HCM/FELEX is considered one of the unknown procurement success stories in recent years (it largely adhered to its time schedule and budget). The HCM/FELEX even achieved international attention with the project's prime contractors securing export contracts for upgrading the Royal New Zealand Navy's ANZAC Class frigates and the Chilean Navy's Type-23 frigates. The modernization upgrades to Canada's twelve Halifax-Class frigates over a seven-year period, between 2010 and 2017, saw the backbone of the RCN given a twenty year life extension with brand new software, communications and weapons systems. For these reasons, the HCM/FELEX serves as a template for testing which of the independent variables were responsible for determining project success and principally whether the political executive was a key to ensuring project success.

Lastly, Chapter Seven summarizes the analyses from the four case studies. This chapter will assesses whether the political executive was responsible for delaying the procurement projects and for what reasons. This chapter also addresses the role of the political executive in two more recent interim procurement projects - the Interim Auxiliary Oil Replenishment ship

\footnotetext{
${ }^{79}$ Canada. Public Services and Procurement Canada. Fixed-Wing Search and Rescue Aircraft Replacement Project. Accessed April 15, 2017. http://www.tpsgc-pwgsc.gc.ca/app-acq/amd-dp/air/arsvf-fwsar/index-eng.html.
} 
and the purchase of eighteen used Australian F-18s. Special attention will be paid to proposing possible policy solutions for improving the defence procurement process and future research areas.

\section{Terminology}

Both the Stephen Harper and Justin Trudeau governments have introduced name changes to the CAF and federal departments, respectively. In 2011 the Harper government reintroduced the pre1968 unification names to the three armed services comprising the CAF: the navy, or Maritime Command became the Royal Canadian Navy (RCN); the army, or Land Force Command became the Canadian Army (CA); and the air force, or Air Command became the Royal Canadian Air Force (RCAF). After taking power in 2015 Justin Trudeau's Liberal government announced name changes to several departments connected to the defence procurement process: Public Works and Government Services Canada (PWGSC) became PSPC and Industry Canada (IC) became ISEDC. Likewise, the National Shipbuilding Procurement Strategy (NSPS) became the National Shipbuilding Strategy (NSS). Both sets of terminology are used in this dissertation. 


\section{Chapter 2 - The Defence Procurement System, Process and Policy Environment}

\section{Introduction}

The Canadian defence procurement system is commonly viewed as one of the most complex among any of the country's allies. ${ }^{1}$ Therefore, any analysis of a specific MCP must begin with an explanation of how the process works and the composite parts that make it work. In this case, the procurement process exists within a defence procurement system. These include statutes and regulations; specific trade agreements and a quasi-judicial body, the Canadian International Trade Tribunal (CITT); the departments of National Defence (DND), Public Services and Procurement Canada (PSPC), and Innovation Science and Economic Development Canada (ISEDC); Treasury Board and the Treasury Board Secretariat (TBS); and the political executive ministers (i.e. cabinet), cabinet committees, the prime minister and their staff - discussed in Chapter One (see Table 1, page 50).

Together, these laws, institutions and actors shape what is the five-stage defence procurement process (see Table 2, page 55). A MCP will begin with 'project identification' in DND and end with the 'close-out'. Of course, defence procurement does not exist in a political vacuum. Rather, the process of acquiring a MCP for the armed forces has long been impacted by the Canada's broader defence policy environment. This environment broadly consists of both interrelated external and internal variables: geography, military alliances, public opinion,

\footnotetext{
${ }^{1}$ Canada. Library of Parliament - Parliamentary Information and Research Service. The Evolution of Defence Procurement in Canada. Ottawa: 2016; Ugurhan Berkok, "Canadian defence procurement", in Defence Procurement and Industry Policy: A small country perspective, eds. Stefan Markowski, Peter Hall and Robert Wylie (New York: Routledge, 2010); Kim Richard Nossal, Charlie Foxtrot: Fixing Defence Procurement in Canada (Toronto: Dundurn Press, 2016); Sloan, Elinor. Something Has To Give: Why Delays Are The New Reality of Canada's Defence Procurement Strategy (Calgary: Canadian Defence and Foreign Affairs Institute and University of Calgary, 2014), 5.
} 
budgets, and regionalism. ${ }^{2}$ Consequently, this chapter will provide an overview of the defence procurement system, process and defence policy environment to better situate the four MCPs analyzed in the subsequent chapters.

\section{Defence Procurement System}

The first step in examining the defence procurement system is to look at the legislation and regulatory framework that define the roles and relationships between departments and the central agencies. Defence procurement in Canada is primarily a shared concern between two major departments, DND and PSPC. PSPC is the official contracting authority and derives its authority from the Department of Public Works and Government Services Act (1996). This Act makes PSPC the contracting authority for all federal goods and services. ${ }^{3}$ This creation of a "common service agency" for all government purchasing was the result of the June 1993 merger between the Department of Supply Services, the previous federal contracting arm, and the Department of Public Works, into the Department of Public Works and Government Services Canada (PWGSC). Under this new department (renamed in 2015 to PSPC) PSPC was made responsible for supporting the programs of "departments, boards, and agencies of the Government of Canada with services" including the acquisition of "articles, supplies, machinery, equipment, and other material". ${ }^{4}$ Under this merger, responsibility for defence procurement

\footnotetext{
${ }^{2}$ Jeffrey Collins, "The Perpetual Search for Efficiency: The Canadian Approach to the RMA and Military Transformation”, in Reassessing The Revolution In Military Affairs: Transformation, Evolution and Lessons Learnt, eds. Jeffrey Collins and Andrew Futter (London: Palgrave Macmillan, 2015), p. 51.

${ }^{3}$ Canada. Public Works and Government Services Canada. "Supply Manual," Section 1.20, accessed August 8, 2016, https://buyandsell.gc.ca/policy-and-guidelines/supply-manual/section/1.

${ }^{4}$ Canada. Library of Parliament - Parliamentary Information and Research Service, The Evolution of Defence Procurement in Canada.
} 
passed to PSPC with the transfer of the Defence Production Act (1985) from the Department of Supply Services.

Through the Defence Production Act PSPC has "exclusive authority" to buy or acquire defence goods and build defence infrastructure on behalf of DND and the Canadian Armed Forces (CAF). Notably, both Acts stipulate that the PSPC minister can only issue contracts once Cabinet approval is given. ${ }^{5}$ While it is true that the National Defence Act (1985) fails to provide a statutory basis for DND's involvement in defence procurement, in practice the two departments have agreed to a division of responsibilities that are governed by memoranda of understanding and encapsulated in PSPC's Supply Manual. Dividing responsibility is officially viewed as a way to better ensure that the process is more effective and efficient. ${ }^{6}$ Of note, this division of responsibilities only applies to military material and services (e.g. purchasing photocopiers for DND are excluded). The Supply Manual sets out the "policies and procedures...references to acts and directives, for the procurement of goods, services and construction". ${ }^{7}$ In other words, the Supply Manual is the 'go to' guide for federal contracting rules. According to the agreed division of responsibilities in the Supply Manual, PSPC is "the lead department responsible for developing the procurement plan; soliciting and evaluating bids; as well as preparing, awarding, administering, and closing contracts". ${ }^{8}$ DND's responsibilities lay with “defining operational and technical requirements, preparing the procurement instrument, and conducting acceptance trails and tests related to the delivery of the material or services procured..."9

\footnotetext{
${ }^{5}$ Canada. Public Works and Government Services Canada. "Supply Manual," Section 1.20.10.

${ }^{6}$ Canada. Public Works and Government Services Canada. "Supply Manual," Annex 1.1.2.

${ }^{7}$ Canada. Public Works and Government Services Canada. "Supply Manual," accessed July 11, 2017, https://buyandsell.gc.ca/policy-and-guidelines/Supply-Manual.

${ }^{8}$ Canada. Library of Parliament - Parliamentary Information and Research Service, The Evolution of Defence Procurement in Canada.

9 Ibid.
} 
This means that at the beginning of each MCP and in keeping with the arrangement laid out in the Supply Manual, DND and PSPC will sign memorandums of understanding on the delineation of "project management responsibility between [the] two departments". ${ }^{10}$ Specifically, DND takes the lead in setting the Statement of Requirements (SOR), the 'Rough Order of Magnitude' costs (i.e. the early project cost estimates) and getting approval from Cabinet. In these regards, and if its required, DND cooperates with PSPC in writing and submitting the procurement project's 'Memorandum to Cabinet' (MC) for policy approval which typically occurs at a defence policy specific cabinet committee. For much of the Harper government this was the Foreign Affairs and Defence Cabinet Committee (later renamed Foreign Affairs and Security), however, if the equipment was related to the Afghanistan war the MC typically went to the ad-hoc Afghanistan Cabinet Committee during the years it operated, 20082011. For a brief period, 2007-2008, there was even an ad-hoc cabinet committee that made decisions on the 2008 Canada First Defence Strategy. Sometimes, if it concerned a major policy item, like the 2010 National Shipbuilding Procurement Strategy, the prime minister's Priorities and Planning Cabinet Committee (now known as 'Agenda, Results and Communications') weighed in. ${ }^{11}$ Under the Justin Trudeau government there is now a specific Cabinet Committee on Defence Procurement (see Chapter Seven), chaired by the president of the Treasury Board, although it remains too early to tell how effective it will be in facilitating the movement of MCPs through the procurement process. ${ }^{12}$ Both departments will also cooperate in establishing resource

\footnotetext{
${ }^{10}$ Canada. Public Works and Government Services Canada. "Supply Manual," Section 1.45(e).

${ }^{11}$ Smith, "When cabinet decides: Parsing Canadian defence politics"; Nicholas Gammer, "The Afghanistan Task Force and Prime ministerial Leadership: Tactical Retreat or a New Direction in Managing Canadian Foreign Policy?," American Review of Canadian Studies 43, No. 4 (2013): 469; Mike Blanchfield, "Conservatives shut down key Afghan cabinet committee," The Globe and Mail, January 5, 2011; Subject Matter Expert \#1, telephone interview with the Author, September 28, 2016; Subject Matter Expert \#2, telephone interview with the Author, October 5, 2016.

${ }^{12}$ Canada. Prime minister of Canada. "Cabinet committee mandates and membership." accessed July 12, 2017. http://pm.gc.ca/eng/cabinet-committee-mandate-and-membership.
} 
requirements for the MCP's life-cycle cost. Finally, PSPC takes the lead in preparing the bid package for would-be bidders, issuing the 'Request For Proposals' (RFP), and ensuring that the contracting process is in compliance with both CITT case decisions and Federal Court rulings. If there is to be a sole-source contract (see below), PSPC will negotiate the contract with the company in question and seek Treasury Board approval for it. ${ }^{13}$

Separate from PSPC and DND is Innovation, Science and Economic Development Canada (ISEDC, formerly Industry Canada). ISEDC plays a secondary but nonetheless important role. This department is responsible for administering the Industrial Regional Benefits (IRB) program for those MCPs initiated before February 2014, when the Defence Procurement Strategy was introduced, and the subsequent Industrial and Technological Benefits (ITBs) program. The federal government's IRBs requirement - which applied to all four case studies in this dissertation - had successful RFP bidders spend in-kind or new dollars at the equivalent of 100 percent of their contract in Canada. As the term implies, the dollars/in-kind contribution is then spent across different regions of the country. A common tactic is for a prime contractor to team up with sub-, or secondary, contractors located in different regions to increase their bid's total number of points in ISEDC's evaluation. For example, with the Fixed-Wing Search and Rescue plane, the winning bidder, European firm Airbus Defence and Space, partnered with PAL Aerospace in Newfoundland, firms Pratt and Whitney and CAE in Quebec, and L-3 WESCAM in Ontario. ${ }^{14}$ The current IRB policy was approved by the Brian Mulroney cabinet in 1986 following industry complaints on the lack of Canadian technological and developmental opportunities that emerged out of the procurement of Leopard I tanks, CP-140 long range patrol

\footnotetext{
${ }^{13}$ Canada. Public Works and Government Services Canada. "Supply Manual," Annex 1.1.2.

${ }^{14}$ David Pugliese. "RCAF fixed-wing SAR contract awarded to Airbus now being challenged in federal court." The Ottawa Citizen, February 23, 2017.
} 
aircraft, and CF-18 fighters in the late 1970s and early 1980s. ${ }^{15}$ In contrast to IRBs, the new ITB model requires successful bidders to make business investments in certain key technological sectors instead of regions. These investments still need to match 100 percent of the contract, however, now bidders must tell ISEDC how much of this investment, known as a 'Value Proposition', will go to addressing four priority areas: (1) growing Canada's defence sector; (2) providing work for Canadian suppliers, especially small and medium-sized enterprises "in all regions of the country"; (3) undertaking research and development; (4) and promoting exports. Bidders are then weighted on their ability to meet ITBs. ${ }^{16}$ Notably, while industrial offsets typically attracted political executive interference in the past (e.g. the Canadian Patrol Frigate project in the 1980s) nowadays with introduction of the Financial Accountability Act in 2006 and a rigorous Treasury Board Contract Policy, cabinet ministers are more likely to avoid influencing how and where offsets go because of "concerns over lawsuits and litigation". ${ }^{17}$

Central agencies like the PCO, Treasury Board and the TBS are also important actors in the procurement system. The PCO provides "logistical support to cabinet and its committees". For defence procurement purposes, the PCO reviews and analyses policies and programs for cabinet and the prime minister, disseminates cabinet committee decisions, and helps departments prepare MCs for submission. ${ }^{18}$ Within DND, the ADM for Policy (ADM (Pol)) will oversee the writing of the MC while the ADM (Mat) will ensure that a proposed MC for a new Major Crown Project is vetted by PCO, the Finance Department, and the Treasury Board before it ever goes

\footnotetext{
${ }^{15}$ Fergusson, James. "In Search of a Strategy." In The Economics of Offsets, edited by Stephen Martin, 107-137. (Amsterdam: Harwood Academic, 1996).

${ }^{16}$ Canada. Industry Canada. "Industrial and Technological Benefits Policy: Value Proposition Guide" (Ottawa: 2014); Nossal, Charlie Foxtrot, 98; Auger, The Evolution of Defence Procurement in Canada, 8-9.

${ }^{17}$ Subject Matter Expert \#1, telephone interview with the Author, September 28, 2016.

${ }^{18}$ David Johnson, Thinking Government: Public Administration and Politics in Canada (Toronto: University of Toronto, 2011), 181-182, 191.
} 
before a cabinet committee; in the words of former ADM (Mat) Alan Williams, by checking with PCO first DND should know the outcome of a MC before it goes to cabinet. ${ }^{19}$ PCO does not want to risk breaking cabinet solidarity by having a $\mathrm{MC}$ go before it that knowingly lacked consensus. Consequently, PCO officials will try to achieve such a consensus by speaking to senior bureaucrats at the relevant departments (this applies to both defence and non-defence items) before moving a MC to cabinet for policy approval. ${ }^{20}$ If consensus was not reached beforehand and a project that went before cabinet is rejected (as happened with a number of projects in the Martin Liberal government) then the project will simply stall. ${ }^{21}$ It is important to stress that not all Major Crown Projects end up in front of cabinet as an MC; only projects deemed to be "politically sensitive" are considered for ministerial discussion, debate and approval. ${ }^{22}$ Such common sensitivities include cost - especially if the project is more than $\$ 1$ billion, whether there are significant jobs at stake and whether this will 'play' well politically (e.g. National Shipbuilding Procurement Strategy), possible federal-provincial ramifications, and concerns over possible electoral and political fallout from a 'toxic' project (e.g. F-35). ${ }^{23}$

The TBS is the bureaucratic body that supports the Treasury Board, a permanent cabinet committee. Headed by a cabinet minister, the president of the Treasury Board, the Treasury Board includes half-a-dozen or more ministers of which one is always the minister of finance. The overarching goal of the Board/TBS is to help "ensure tax dollars are spent wisely and effectively for Canadians". ${ }^{24}$ More specifically, as it relates to procurement, these organizations

\footnotetext{
${ }^{19}$ Phone interview with Alan Williams, former ADM (Mat), September 5, 2016; Confidential phone interview with Author, February 16, 2017.

${ }^{20}$ Confidential interview with a former senior government official, Ottawa, September 26, 2016.

${ }^{21}$ Confidential phone interview, January 14, 2017.

${ }^{22}$ Alan Williams, telephone interview with the Author, September 5, 2016.

${ }^{23}$ Confidential telephone interview with the Author, January 14, 2017.

${ }^{24}$ Canada. Treasury Board of Canada Secretariat. "Treasury Board of Canada Secretariat," accessed August 9, 2016, https://www.canada.ca/en/treasury-board-secretariat.html.
} 
exist to turn cabinet approved programs and policies, like the National Shipbuilding Procurement Strategy, into "operational reality". ${ }^{25}$ The Secretariat assists the Board in its decision-making functions by reviewing and vetting all departmental budgets to ensure that they adhere to the Finance Department's established parameters. As well, the Secretariat will analyze departmental budgets to see if they comply with government spending targets and priorities. ${ }^{26}$ Among its functions, and subject to its approval, Treasury Board releases the first phase of funding for MCPs approved by cabinet - this is known as Preliminary Project Approval (PPA). It also releases the remainder of a MCP's budget once a winning bid has been identified by PSPC, this is known as Effective Project Approval (EPA) (see Section III).

However, as Perry notes, outside of PPA and EPA the Treasury Board/TBS influences a MCP's schedule in a myriad of ways some of which may create confusion and cause delays. Because of high-profile procurement failures like the Fixed-Wing Search and Rescue plane and the Joint Support Ships, extra layers of reporting requirements have been built into the procurement process. For instance, Treasury Board requires DND to establish life-cycle costing for every MCP and to document any project changes - both of which have been found to be taxing on DND/CAF's human resources and complex to do. A life-cycle costing is exactly that: estimating the total cost of a Major Crown Project from its acquisition through decades of usage and eventual disposal. However, failure to undertake either properly can result in delays (as happened with the MSVS-Standard Military Pattern trucks in 2012). Similarly, governance structures created for specific projects (e.g. secretariats for the FWSAR and National Shipbuilding Procurement Strategy) have their own Treasury Board/TBS reporting requirements

\footnotetext{
${ }^{25}$ Canada. Treasury Board of Canada Secretariat, “About the Treasury Board of Canada,” accessed July 13, 2017, https://www.canada.ca/en/treasury-board-secretariat/corporate/about-treasury-board.html.

${ }^{26}$ Johnson, Thinking Government, 186.
} 
to meet, and can be equally constraining for DND. Lastly, delays can emerge indirectly because of TBS's 'Organizational Project Management Capacity Assessment' (OPMCA). A part of the Board's 2007 Policy on the Management of Projects, the OPMCA uses a four-level rating system to evaluate the management capacity and risk threshold of a MCP and a department. The higher the number ( 4 is ideal) the less Treasury Board approvals are needed. If a project or a department scores a lower OPMCA level, then expenditures which could have been approved at the ministerial level now require Treasury Board approval and more reporting. In the case of DND its rating dropped from a 3 to a 2 in the aftermath of the failed attempt to sole-source the F$35 .^{27}$

Treasury Board ministers can also attach conditions to an MCP “if they don't like where the project is going". For example, DND may be asked to report periodically to the Board on the measures it is taking to ensure that a project remains within its allotted budget. Such conditions are generally not done on a whim but reflect the risk assessments prepared by the Secretariat. Like other reporting requirements, these attachments become yet another process in and of themselves as DND must ensure that people, time and resources are set aside to meet Treasury Board's conditions. ${ }^{28}$ A final challenge for any department, not just National Defence, is getting in front of the Board to begin with. When the House of Commons is in session Treasury Board will meet weekly, however, both it and the Secretariat look at submissions from across government. This means that both organizations have "limited bandwidth to examine just DND issues". It therefore is incumbent on DND to prioritize which MCPs it wants sent to Treasury Board for PPA, EPA, or another reporting requirement. This can be a challenge although the nine

\footnotetext{
27 Perry, Putting the 'Armed' Back Into the Canadian Armed Forces: Improving Defence Procurement in Canada, 7-8; This was also confirmed in interviews: Confidential telephone interview with the Author, February 16, 2017. ${ }_{28}$ Auger, The Evolution of Defence Procurement in Canada, 8-9; Senior Government Official, Interview with the Author, September 23, 2016.
} 
directors general in ADM (Mat) plus representatives of the three armed services attempt to do such prioritizing at weekly, Friday morning meetings when Treasury Board is in session. But consensus can be elusive as this process only works when "people volunteer to take things off the priority list" as an IOU..$^{29}$

Reporting requirements aside, another core part of Treasury Board's responsibilities is overseeing what former Assistant Deputy Minister (Material) Alan Williams' terms of as one of the two most influential instruments in the procurement process, the Contracting Policy (the other is the Agreement on Internal Trade - see below). ${ }^{30}$ A part of the Financial Administration Act (1985), the Contracting Policy posits that where possible procurement contracts are to be competitive - something that makes Canada unique in comparison to its allies. ${ }^{31}$ The competitiveness goal operates in line with other government policies, key of which is, "to acquire goods and services and to carry out consultations in a manner that enhances access, competition, and fairness and results in best value". The Contracting Policy does provide flexibility for acquisitions through non-competition, or 'sole-sourcing', but such actions must provide "the optimal balance of overall benefit to Canada and the Canadian people". 32 Specifically, the Policy allows for four exceptions for deviating away from a procurement competition: (1) a "pressing emergency" (e.g. natural disaster, war); (2) only one business can do the work; (3) the "nature of the work" (e.g. national security); (4) and that the intended contract does not exceed $\$ 25,000$ for goods or $\$ 100,000$ for services. ${ }^{33}$ If it is deemed that a noncompetitive purchase is warranted, then PSPC will conduct a sole-source contract. Sole-sourcing

\footnotetext{
${ }^{29}$ Confidential phone interview with the Author, February 16, 2017.

${ }^{30}$ Williams, Reinventing Canadian Defence Procurement: A View from the Inside, 7.

${ }^{31}$ Ibid., 7.

${ }^{32}$ Canada. Public Works and Government Services Canada. "Supply Manual," Section 1.30.5.

${ }^{33}$ Williams, Reinventing Canadian Defence Procurement, 15-16. Contracts for the Canadian International Development Agency have a competition exemption level of $\$ 100,000$ for services.
} 
was relied upon for many procurement purchases between 2006-2015, including the C-17s/C130Js, Chinook helicopters, Leopard II tanks, and the initial attempt to acquire the F-35. Except for the F-35, these projects were generally connected to meeting the needs of the CAF in Afghanistan.

Overall federal procurement is also subject to trade agreements, however, the North American Free Trade Agreement and World Trade Organization - Agreement on Government Procurement provide for exemptions on national security grounds. ${ }^{34}$ This leaves the Canadianonly Agreement on Internal Trade (AIT) as the one trade agreement still impacting defence procurement. ${ }^{35}$ Of note, the AIT was replaced on July 1, 2017 with the Canada Free Trade Agreement. Although the AIT articles relevant to defence procurement were carried over all the case studies in this dissertation are subject to the AIT provisions; only post-July 1, 2017 MCPs are subject to expanded provisions of the CFTA. The AIT covered acquisitions at both the federal and provincial level. Article 501 of the AIT required "equal access to procurement for all Canadian suppliers"; the idea being that pan-Canadian competition lowers purchasing costs and supports economic development. But, foreign companies can be considered a 'Canadian supplier' if they are based in Canada. In defence procurement terms, this usually takes the form of a subsidiary of a major U.S. or European prime contractor like Boeing or ThyssenKrupp Marine Systems. Crucially, the AIT's Article 506.11(a), like the Contracting Policy to which it is aligned, allowed for a non-competitive contract when a "situation of urgency exists". ${ }^{36}$ Such an 'Urgent Operational Requirement' (UOR) was deemed to have existed in the earlier phase of the CAF's involvement in Afghanistan, the 2003-2005 Operation Athena. During Athena the threat

\footnotetext{
${ }^{34}$ Canada. Public Works and Government Services Canada. "Supply Manual," Section 1.25.1.

${ }^{35}$ Williams, Reinventing Canadian Defence Procurement, 7-8.

${ }^{36}$ Ibid., 11-12.
} 
of roadside bombs and Taliban attacks dictated that the CAF acquire reconnaissance Unmanned Aerial Vehicles (UAVs), or drones, as soon as possible. A sole source contract valued at \$33.8 million was eventually issued for six Sperwar UAVs and the equipment was promptly delivered. $^{37}$

Like NAFTA and the WTO-AGP, the AIT was subject to the Canadian International Trade Tribunal, or CITT. The CITT is the adjudicative body for complaints related to "any aspect of the [procurement] process", including right up to contract award. The CITT can conduct inquiries and make determinations. ${ }^{38}$ Responsible to Parliament and reporting to the minister of finance, the CITT accepts complaints on tariff classifications, subsidies, and federal procurement generally. Once an inquiry is completed the CITT can recommend that contracts not be signed and/or that Ottawa cover a complainant's cost for launching the complaint. The Tribunal can also recommend, although the federal government is not required to accept, that a new competition be started, bids be re-evaluated, a contract be awarded to another bidder, or that a bidder be compensated for lost profit. It is worth noting that complaints are relatively few when compared to the share number of contracts PSPC awards annually. In 2003/04, PSPC issued 13,100 contracts valued at nearly $\$ 6$ billion of which only 64 complaints were registered, "half of one percent of the total". ${ }^{39}$ The Medium Support Vehicle System - Standard Military Pattern truck project was, however, one such defence procurement project that became the subject of a CITT complaint. In 2016, the CITT asked that the federal government re-evaluate the rejected \$834 million bid of U.S. company Oshkosh Defence and cover the firm's tribunal process

\footnotetext{
${ }^{37}$ Ibid., Reinventing Canadian Defence Procurement, 12-13.

${ }^{38}$ Canada. Public Works and Government Services Canada. "Supply Manual," Section 1.35.1.

${ }^{39}$ Williams, Reinventing Canadian Defence Procurement, 16-17.
} 
costs. $^{40}$ The Fixed-Wing Search and Rescue airplane was similarly subject to a CITT complaint from a losing bidder in $2016 .{ }^{41}$

\begin{tabular}{|c|c|}
\hline Organization & Roles and Responsibilities \\
\hline Cabinet & $\begin{array}{l}\text { - Ministers' forum for discussion and decision making. May provide } \\
\text { policy approval in principle for some Major Crown Projects. } \\
\text { - Approves official defence policy statements and White Papers. }\end{array}$ \\
\hline Privy Council Office & $\begin{array}{l}\text { - Provides advice on proposals to cabinet. } \\
\text { - Assists departments in preparing proposals to cabinet }\end{array}$ \\
\hline Treasury Board & $\begin{array}{l}\text { - As a statutory committee of cabinet, approves policies in areas such } \\
\text { as project management and contracting. } \\
\text { - Decides whether a project should be deemed a Major Crown } \\
\text { Project. } \\
\text { - When a project is likely to exceed ministerial expenditure authority } \\
\text { limits, approves such projects, allows the departments to enter into } \\
\text { contracts, and may allow exemptions from Treasury Board policies. }\end{array}$ \\
\hline $\begin{array}{l}\text { Treasury Board of } \\
\text { Canada Secretariat }\end{array}$ & $\begin{array}{l}\text { - As the Treasury Board's administrative arm, develops policies and } \\
\text { guidance for the federal government on topics such as project } \\
\text { management and contracting. } \\
\text { - Assists departments in preparing submissions to the Treasury Board. } \\
\text { - Analyzes and challenges departmental submissions. } \\
\text { - Provides recommendations and advice to the Treasury Board on } \\
\text { project proposals. }\end{array}$ \\
\hline
\end{tabular}

\footnotetext{
${ }^{40}$ Amanda Connolly, "Re-evaluate Oshkosh Defense's bid for \$834M-deal: trade tribunal to Public Works", iPolitics, accessed August 8, 2016, https://ipolitics.ca/2016/05/24/re-evaluate-oshkosh-defenses-bid-for-834m-dealtrade-tribunal-to-public-works/.

${ }^{41}$ Amanda Connolly, "Trade tribunal dismisses challenge of search-and-rescue procurement," iPolitics, accessed July 13, 2017, http://ipolitics.ca/2017/05/05/trade-tribunal-dismisses-challenge-of-search-and-rescue-procurement/. ${ }^{42}$ Table and text, with author's amendments, comes from: Canada. Office of the Auditor General of Canada. Chapter 5: Acquiring Military Vehicles for Use in Afghanistan. Ottawa: 2009, 4-5.
} 


\begin{tabular}{|c|c|}
\hline $\begin{array}{l}\text { Department of National } \\
\text { Defence/Canadian } \\
\text { Armed Forces }\end{array}$ & $\begin{array}{l}\text { - Initiates and manages acquisition projects. } \\
\text { - } \quad \text { Defines project requirements. } \\
\text { - } \quad \text { Pnalyzes and recommends options. } \\
\text { - Proposes a procurement strategy. } \\
\text { - Performs quality assurance, receives goods, and authorizes } \\
\text { payments. }\end{array}$ \\
\hline $\begin{array}{l}\text { Public Services and } \\
\text { Procurement Canada }\end{array}$ & $\begin{array}{l}\text { - Manages the contracting process. } \\
\text { - Conducts market analyses. } \\
\text { - Develops final procurement strategies. } \\
\text { - Prepares bid documents and conducts tendering processes. } \\
\text { - Awards contracts. }\end{array}$ \\
\hline $\begin{array}{l}\text { Innovation, Science, } \\
\text { Economic Development } \\
\text { Canada (ISEDC) }\end{array}$ & $\begin{array}{l}\text { Administers the Industrial Regional Benefit Policy/Industrial and } \\
\text { Technological Benefits Policy, which provides a framework for } \\
\text { linking federal defence procurement to long-term industrial and } \\
\text { regional development in Canada. The advent of ITBs in } 2014 \text { have } \\
\text { seen ISEDC focus on growing the defence industrial base, especially } \\
\text { in SMEs. } \\
\text { - Ensures that socio-economic objectives are considered when a major } \\
\text { defence acquisition is made. }\end{array}$ \\
\hline $\begin{array}{l}\text { Canadian International } \\
\text { Trade Tribunal }\end{array}$ & $\begin{array}{l}\text { Inquire into complaints made by companies concerning any aspect } \\
\text { of the procurement process. The rulings of this quasi-judicial body } \\
\text { are recommendations only. }\end{array}$ \\
\hline
\end{tabular}




\section{The Defence Procurement Process}

A MCP moved through a series of steps known as the 'Capital Approval Process'. This process is comprised of five broad stages, is "highly structured", and is mandated by the TBS. ${ }^{43}$ For the MCPs examined in this dissertation the process existed as follows (see Table 2, page 55 for a summary):

Stage One - Project Identification: defence planners within the DND conduct an examination of current defence policy (e.g. the 2008 Canada First Defence Strategy) and extrapolate into the future what the potential security threats and challenges could be. Planners then develop a series of scenarios in which capability deficiencies and gaps can be identified. ${ }^{44}$ Capability identification is generally sponsored by one of the armed services; either the Canadian Army, the Royal Canadian Navy, or the Royal Canadian Air Force. Further evaluation takes place regarding possible funding sources, policy support (i.e. does current government defence policy support the desired capability?), and the potential risks in addressing the capability deficiency. Once completed, the capability proposal is assessed by the DND's Defence Capability Board and, if approved, officially becomes a project. $^{45}$

\section{Stage Two - Options Analysis: At this stage, the Statement of Operational Requirement} (SOR) is developed, "and the optimal method to addressing the capability gap is identified". 46 The SOR involves an analysis of the costs and benefits on the options available to satisfy the desired capability. ${ }^{47}$ DND will send letters of interest to industry in order to obtain a 'Rough

\footnotetext{
${ }^{43}$ Canada. National Defence and the Canadian Armed Forces. Defence Acquisition Guide 2016 (Ottawa: 2016); Williams, Reinventing Canadian Defence Procurement, 38-39.

${ }^{44}$ Sloan, Elinor. Something Has to Give: Why Delays are the New Reality of Canada's Defence Procurement Strategy. Calgary: Canadian Defence \& Foreign Affairs Institute, 2014, 8.

45 Perry, 2015 Status Report, 2.

46 Perry, 2015 Status Report, 2.

${ }^{47}$ Perry, 2015 Status Report, 2.
} 
Order of Magnitude' (ROM) cost of the "particular platform or capability in question" ${ }^{48}$ ROM gives DND an early estimate of the budgetary requirements needed for the capability. Next, the department's "senior leadership will determine the option to proceed with based on the project business case analysis". ${ }^{49}$ If the project is valued in excess of $\$ 30$ million, which all MCPs are, it must be submitted to Treasury Board for Preliminary Project Approval (PPA). ${ }^{50}$

Stage Three - Definition: If PPA is given, Treasury Board will "establish a dollar amount or budget for the project, based on the ROM-cost inputs, and on the requirement to support industrial and regional benefits (now ITBs)" ${ }^{51}$ The subsequent task will be to determine "how the preferred option will be implemented". ${ }^{52}$ The DND will establish a project management office specifically for that MCP. The office is composed of a mix of DND/CAF personnel and consultants. They will refine the capability requirement, calculate the project's cost and schedule estimates, while investigating and mitigating risk. The money approved under PPA is then allocated for a final round of consultations with industry. If the project is deemed to be a highrisk because of costs or technical requirements, a 'Statement of Interest and Qualification' will be sent to potential industry bidders in order to ascertain whether their companies are "capable of answering the eventual 'Request For Proposals"” (RFP). ${ }^{53}$ National Defence, PSPC, and ISEDC rely on the SOIQ feedback to " "pre-qualify" bidders that should receive the tender". ${ }^{54}$ Ideally, the formal RFP will usually close anywhere between two and six months after issuance. Once

\footnotetext{
${ }^{48}$ Sloan, Something Has to Give, 8.

${ }^{49}$ Canada. National Defence and the Canadian Armed Forces. Defence Acquisition Guide 2016, "Project Approval Process".

${ }^{50}$ Perry, 2015 Status Report, 2.

${ }^{51}$ Sloan, Something Has to Give, 9.

${ }^{52}$ Canada. National Defence and the Canadian Armed Forces. Defence Acquisition Guide 2016, "Project Approval Process".

${ }^{53}$ Ibid.; Sloan, Something Has to Give, 9.

${ }^{54}$ Ibid.
} 
interested bidders have supplied the necessary information for the RFP, the bids are assessed for compliance. If no bidders are compliant the RFP is cancelled (as happened with the Joint Support Ships) and a new RFP has to be initiated with more industry consultations. ${ }^{55}$ The RFP can also be cancelled by PSPC, with TBS support, if its ADM for Procurement thinks DND/CAF have not followed the appropriate procedures up to that stage - as happened with the MSVS Standard Military Pattern project. By the end of the Definition stage, a winner is selected and the project returns to the Treasury Board for Effective Project Approval (EPA) ${ }^{56}$ With the RFP now complete, the procurement process is said to have entered the "beginning of formal procurement" as there can be no more political involvement from cabinet. ${ }^{57}$

Stage Four - Implementation: If EPA is granted, the DND can now proceed to having a contract awarded through PSPC. ${ }^{58}$ Sloan refers to this stage as the "go and buy" decision. ${ }^{59}$ It is PSPC that awards the contract and is responsible for protecting the integrity of the tendering process. ${ }^{60}$ With the contract awarded the equipment begins to be delivered; eventually enough equipment will be delivered, tested and accepted that the project is designated as having achieved Initial Operational Capability (IOC). This is when the equipment can be deployed by the CAF operationally. Full Operational Capability (FOC) is obtained once all the equipment has been delivered. ${ }^{61}$

Stage Five-Close-Out: At this point, the project has achieved full operational capability and the equipment is in service. The DND's Defence Acquisition Guide states that the capability is

\footnotetext{
${ }^{55}$ Ibid.

${ }^{56}$ Perry, 2015 Status Report, 2.

${ }^{57}$ Williams, Reinventing Canadian Defence Procurement, 43.

${ }_{58}^{58}$ Perry, 2015 Status Report, 2.

${ }^{59}$ Sloan, Something Has to Give, 9.

${ }^{60}$ Canada. National Defence and the Canadian Armed Forces. Defence Acquisition Guide 2016, "Project Approval Process".

${ }^{61}$ Perry, 2015 Status Report, 2.
} 
now considered a "managed capability". ${ }^{62}$ The project management office shrinks to a skeletal staff which remain on hand to conduct analyses on key lessons learned, and to map out the project's outcomes against the initial goals. This information is used for improving future procurement management practices and procurement procedures.

\begin{tabular}{|c|c|}
\hline Stage & Key Components \\
\hline 1. Identification & $\begin{array}{l}\text { - } \text { Capability is identified by planners within the CAF. } \\
\text { - Defence Capability Board approves capability } \\
\text { assessment. Project status officially acquired. }\end{array}$ \\
\hline 2. Options Analysis & $\begin{array}{l}\text { - Statement of Requirement is developed. } \\
\text { - 'Rough order of magnitude' costs are established. } \\
\text { - } \quad \text { May go to cabinet (if policy approval required). } \\
\text { - Preliminary Project Approval from Treasury Board is } \\
\text { sought. If given, a project management office is stood up } \\
\text { and a project budget is identified. }\end{array}$ \\
\hline 3. Definition & $\begin{array}{l}\text { - Industry consultations take place. } \\
\text { - Project options are considered and refined. } \\
\text { - 'Request for Proposals' is issued. } \\
\text { - Effective Project Approval from Treasury Board is } \\
\text { sought. If given, the project can go to tender under the } \\
\text { auspices of PSPC. }\end{array}$ \\
\hline 4. Implementation & $\begin{array}{l}\text { - } \\
\text { - SSPC awards a contract. } \\
\text { (project enters Initial Operational Capability). } \\
\text { - Full Operational Capability (FOC) is achieved once all } \\
\text { equipment is delivered. }\end{array}$ \\
\hline 5. Close Out & - Project has achieved FOC. \\
\hline
\end{tabular}

${ }^{62}$ Canada. National Defence and the Canadian Armed Forces. Defence Acquisition Guide 2016, "Project Approval Process". 
- Project management office is reduced.

\section{External Defence Policy Environment}

Commentary on Canadian defence policy, in comparison to Canadian military history, is limited.

Of what has been written, the external defence policy environment comprised of the interconnected factors of Canada's geo-strategic position and military alliances, stands out. ${ }^{63}$ Sitting atop the North American continent, Canada remains situated in one of the most secure and stable geostrategic locations in the world. Lacking any existential threats, Canadian decision-makers are thus incredibly fortunate considering that at 18 million square kilometres and an unevenly distributed population of 36 million people - 90 percent of whom live within 160 kilometres of the U.S. border - Canada is a tough country to defend. ${ }^{64}$ Geography also makes Canada an expensive country to defend. Former Chief of Defence Staff Walter Natynczyk has said that it is harder to sustain CAF operations in the Arctic than it is in Afghanistan. ${ }^{65}$

A secure geographic position has meant that Canadian governments have had to pay, literally and figuratively, little attention to strategic issues. Instead, as Nossal states, the aim of Canadian defence policy has not so much been about defending the homeland as it is "to defend something else besides Canada and Canadians". ${ }^{66}$ This is because geography has granted Canada, throughout its post-1867 history, a great power security guarantor. For the first six decades of its existence Canada relied upon the United Kingdom and the deterrence force of the

\footnotetext{
${ }^{63}$ R.J. Sutherland, “Canada's Long Term Strategic Situation”, International Journal 17, no. 3 (1962): 201. ${ }^{64}$ Canada. House of Commons. Standing Committee on National Defence. Canada and the Defence of North America, 2nd Session, 41st Parliament, Report no. 13, 2015, 2; Middlemiss, D.W. and J. Sokolsky. Canadian Defence: Decisions and Determinants. Toronto: Harcourt Brace Jovanovich, 1989, 153.

${ }^{65}$ David Pugliese. "Canadian Forces to stockpile military equipment in Arctic 'hubs' for faster response in case of emergency." The National Post, August 21, 2014; Jeffrey F. Collins, "No such thing as a bargain in defence procurement." The National Post, July 2, 2015.

${ }^{66}$ Nossal, Kim Richard, "Defending the 'realm': Canadian strategic culture revisited." International Journal 59, no. 3 (Summer, 2004): 504.
} 
Royal Navy to ensure the country was safe from any would be expansionist aspirations of its southern neighbour. But, as a young dominion under the protection of London Canada was also expected to contribute to collective imperial military interests. This meant dispatching troops, procuring equipment and munitions, and/or contributing funds to the U.K.'s military campaigns, be it against the Boers in South Africa in 1899-1902, the Germans in the First World War from 1914-1918, or the Bolsheviks in civil war-torn Russia in 1919. This status quo largely remains in effect today with the United States.

Canada's move towards Washington's security orbit began in the 1930s as British power declined and relations improved between the U.K. and the U.S. With economic ties growing and after having abandoned a brief flirtation with unilateralism, Canada began to incrementally build security ties with the U.S. ${ }^{67}$ In 1938, amid the deteriorating security situation in Europe and Asia, prime minister Mackenzie King and president Franklin Delano Roosevelt exchanged a series of notes that would cement closer security ties between the two countries. Canada promised not to become a strategic liability to the United States, while Washington promised to ensure that no great power would ever threaten Canada. ${ }^{68}$ This approach to Canada-U.S. defence relations is best understood by the term 'defence against help'. Canadian governments have, since 1938, been wary of forsaking too much autonomy for U.S. security. Under 'defence against help' Canada will do what it takes to ensure that the northern half of the continent is not a threat to its southern neighbour without sacrificing too much control over Canadian sovereignty. In the

\footnotetext{
${ }^{67}$ Sutherland, "Canada's Long Term Strategic Situation", 202, 205.

${ }^{68}$ Middlemiss and Sokolsky, Canadian Defence: Decisions and Determinants, 152.
} 
words of military historian Desmond Morton, "Our priority is to do what we must do to make the Americans feel secure on their northern frontier". ${ }^{69}$

The defence relationship between the two countries solidified once war broke out in 1939. August 1940 saw the beginning of a co-operative, institutional management for continental defence with the Ogdensburg Agreement. Under Ogdensburg, Canada and the United States agreed to joint continental defence with the creation of the Permanent Joint Board on Defence; this was followed by the establishment of the Military Cooperation Committee in 1946. Each country's defence policy was being increasingly synchronized for continental defence, the first of a series of military procurement pacts was agreed to with the 1941 Hyde Park Agreement. This Agreement set the framework for integrating Canada's defence industrial base into the U.S. base by treating Canadian businesses as American "in return for Canada agreeing to purchase integrated weapons platforms from the U.S.". ${ }^{70}$ Further defence industrial agreements, the 1956 Defence Production Sharing Agreement and the 1963 Defence Development Sharing Agreement, have led to a rationalization of the defence industrial base on a continental level to the point where Canadian defence companies are acquitted preferential treatment by the Pentagon. ${ }^{71}$ During the backdrop of the Cold War, the last major defence integration move between the two countries occurred in 1957 when an exchange of letters led to the creation of the currently named North American Aerospace Command, or NORAD. NORAD is tasked with continental air and

\footnotetext{
${ }^{69}$ Cited in Donald Barry and Duane Bratt, "Defense Against Help: Explaining Canada-U.S. Security Relations," American Review of Canadian Studies 38, No. 1 (2008), 80; Ørvik, Nils. "Canadian security and 'defence against help'." Survival 26, No.1 (1984): 26-31.

${ }^{70}$ Stone, Craig. "Defence Procurement and Industry." In Canada's National Security in the Post-9/11 World, edited by David S. McDonough, 73-97. Toronto: University of Toronto Press, 2012, 83.

${ }^{71}$ Canada. House of Commons. Standing Committee on National Defence. Canada and the Defence of North America, 2; Michael Crawford Urban. "A fearful asymmetry: Diefenbaker, the Canadian military and trust during the Cuban missile crisis.” Canadian Foreign Policy Journal 21, No. 3 (2015), 266.
} 
maritime security; with a Canadian as its deputy NORAD is directly responsible to both Washington and Ottawa. ${ }^{72}$

Through these series of agreements Canada has incrementally become the only country committed to defending the American homeland on a bilateral basis. ${ }^{73}$ The physical and military closeness to Washington though is not treated as a carte blanche though. In line with the logic of 'defence against help' Canada has pursued involvement with another, multi-lateral alliance, the North Atlantic Treaty Organization (NATO) - of which Canada was a founding member in 1949. Under NATO, Canadian decision-makers have been able to achieve a number of goals, the first of which is the prestige of being a member of the world's most powerful military alliance. Secondly, NATO membership allows for rebutting criticism on the anti-American left that Ottawa is too close to Washington. In this sense, a North Atlantic alliance can assuage nationalist fears that Canadian sovereignty is in jeopardy while also offsetting "excessive American influence". Lastly, and perhaps most relevant for the purposes of this dissertation, NATO membership does not require a specific level of contribution - any amount of personnel and materiel was, and is, acceptable. This means that Canada can both do its part to keep Europe secure while also keeping defence spending low. ${ }^{74}$ Of course, NATO also serves the self-interest of the CAF by providing a rationale for "spending dollars on conventional military capabilities". ${ }^{75}$ In Murray and McCoy's analysis, the sum total effect of both of Canada's alliances is that Ottawa receives "the military protection of fellow members, most importantly

\footnotetext{
${ }^{72}$ Middlemiss and Sokolsky, Canadian Defence: Decisions and Determinants, 154.

${ }^{73}$ Ibid., 149.

${ }^{74}$ Jockel, Joseph T. and Joel J. Sokolsky. "Canada and NATO: Keeping Ottawa in, expenses down, criticism out... and the country secure”, International Journal (Spring 2009): 316-319; Sutherland, “Canada's Long Term Strategic Situation", 207.

${ }^{75}$ Middlemiss and Sokolsky, Canadian Defence: Decisions and Determinants, 154.
} 
the US, but [does] not have to increase the size and power of its own military for the sake of national security."76

Canada's dual alliances bring non-security benefits as well. With the United States, Canadian companies not only have access to southern defence contracts but have also established tight professional and bureaucratic ties between the CAF and their American equivalents. ${ }^{77}$ Close professional connections similarly exist between Canadian officers and their European counterparts. However, there is a trade-off. Much like Canada's requirement to standardize its forces and equipment along British imperial lines in the early $20^{\text {th }}$ century, today's alliances require that the CAF be interoperable with the U.S. armed forces. Interoperability can be viewed as comprising two forms: operational and technical. The former concerns standardizing procedures and training while the latter, of more concern for procurement purposes, is about acquiring communications, electronics, and weapons systems that allow for the sharing of information "quickly and efficiently" and for military engagement. To say the least, technical interoperability is expensive. ${ }^{78}$ A good example of technical interoperability is the Royal Canadian Navy's twelve Halifax-class frigates and the now decommissioned Iroquois-class destroyers, all of which had encrypted communications software that allow them to "fit seamlessly into US carrier battle groups."79 Under the Halifax-class Modernization/Frigate Life Extension program (the subject of Chapter Six), these frigates will be further integrated into U.S. naval battle groups thanks in part to new communications, sensors, and Harpoon missiles

\footnotetext{
${ }^{76}$ Murray, Robert W. and John McCoy. "From Middle Power to Peacebuilder: The Use of the Canadian Forces in Modern Canadian Foreign Policy." American Review of Canadian Studies 40, No. 2 (2010): 176.

${ }^{77}$ Sokolsky, Joel J. "A Seat at the Table: Canada and its Alliances.” Armed Forces \& Society 16, No. 1 (1989): 12; Leuprecht, Christian and Joel J. Sokolsky. "Defense Policy 'Walmart Style': Canadian Lessons in 'not-so-grand' Grand Strategy." Armed Forces \& Society 41, No. 3 (2015): 541-562.

${ }^{78}$ Richter, Andrew. "Strategic Ambitions and Fiscal Realities: Give the Navy Priority." Policy Options (April, 2002): 27-28.

${ }^{79}$ Elinor Sloan, Security and Defence in the Terrorist Era. Montreal: McGill-Queen's University Press, 2005, 117.
} 
capable of hitting land-based targets - a $\$ 4.3$ billion project. ${ }^{80}$ Likewise, the CF-18 deployment to NATO's air campaign against Serbia in 1999 illustrated the importance for the CAF to keep its equipment fleets up-to-date. During that 78-day conflict, the eighteen CF-18s deployed on that campaign were limited in their usage because of outdated communications suites; this restricted them to operating with only certain allies and in certain weather conditions.

Eventually, a \$1.8 billion Incremental Modernization Program in the early-2000s rectified this gap. ${ }^{81}$

As illustrated above, interoperability and a close military alliance also means that Canada contributes to international operations. During the Cold War, both the NATO and U.S. continental alliances ensured that Canada acquired interoperable equipment, such as Germanmade tanks and U.S.-made fighter jets, for Ottawa to fulfill its alliance obligations. In the postCold War era, operational demands outside of the traditional European and North American defence roles have placed an additional constraint on procurement and spending. Such operations have often taken the form of ad-hoc coalitions led by the United States. As campaigns in Serbia, Afghanistan, Libya, and Iraq have demonstrated, such coalitions place a high onus on having the technical sophistication to participate given that U.S. armed forces comprise the brunt of the military units in the coalition. ${ }^{82}$

Given this dissertation's emphasis on procurement during the Stephen Harper Conservative era, Canada's participation in the U.S. led war in Afghanistan, from 2001 to 2014,

\footnotetext{
${ }^{80}$ David Pugliese, "Modernization of Halifax-class frigates a success, says government", Ottawa Citizen, November 24, 2014).

${ }^{81}$ Sloan, Elinor. The Revolution in Military Affairs: Implications for Canada and NATO. Montreal and Kingston: McGill-Queen's University Press, 2002, 133; “The CF18 Incremental Modernization Program”, CanadianAmerican Strategic Review (December 2003). accessed August 12, 2016: http://www.casr.ca/id-cf18-3-1.htm. ${ }^{82}$ Bland, Douglas. "Canada and Military Coalitions: Where, How, and with Whom?", Institute for Research on Public Policy. Policy Matters 3, no. 3 (2002): 9-10, 27, 35.
} 
is the most important operation for understanding the connection between alliances, operations, and procurement. The counter-insurgency campaign that Canada participated in from 2006 to 2011 especially took a toll on CAF equipment fleets and strained DND procurement processes. In 2008, two years into the conflict, it became clear that the Canadian Army's entire Light Armoured Vehicle (LAV) III fleet had to be replaced because of operational wear and tear. The demands of war saw the DND push for mission-specific equipment like the purchase of 100 Leopard II tanks for $\$ 1.3$ billion and $\$ 375$ million for leasing six Chinook helicopters. Such acquisitions came at the expense of longstanding planned acquisitions, like the Fixed-Wing Search and Rescue plane (see Chapter Five), as capital dollars and project management personnel were re-oriented to dealing with the demands of the war. The billon dollar defence budget increases made in 2005 and 2006 were all but consumed by 2008. Although, some senior DND and CAF officials were later found to have used the war to justify exaggerated project costs that contributed to undermining other longstanding procurement plans. ${ }^{83}$

\section{Internal Defence Policy Environment}

Being secure in both its alliances and geostrategic position has left Canadian defence without an "obvious level for defence expenditures". ${ }^{84}$ For defence planners, they are left with confronting arguably the most important domestic variable on procurement: the federal budget. Perry argues that in Canada defence policy is a direct reflection of defence spending. The defence budget provides better insight into government thinking on defence "priorities and commitments than

\footnotetext{
${ }^{83}$ Perry, “Canada’s seven billion dollar war," 716, 721-722; Plamondon, Aaron. "Equipment Procurement in Canada and the Civil-Military Relationship: Past and Present." Occasional Paper, No. 2. Calgary: Centre for Military and Strategic Studies, 2008, xiiii, 9, 10, 29.

${ }^{84}$ Stone and Solomon, "Canadian Defence Policy and Spending," 150, 152, 154.
} 
the published policy of the day". In Perry's view defence "dollars are policy". ${ }^{85}$ Advocates for more defence spending must contend with more popular, and expensive, social programs like healthcare and employment insurance. This makes defence spending not only politically sensitive but also hard to justify when governments are confronted with deficit spending and increases in debt servicing payments. On a structural level, cash transfers for health, social programs, and employment insurance are, along with debt servicing payments, a structural constraint on the federal treasury. Defence dollars, which on average represent some 20 percent of Ottawa's non-transfer spending, are a tempting source of dollars to target during times of deficit spending and/or cuts to popular social programs. ${ }^{86}$ The reality is that Canadian governments have long prioritized the country's economy over defence. ${ }^{87}$

This was quite evident in the 1990s when the Liberal government of Jean Chrétien attempted to slay an annual $\$ 40$ billion deficit and near crippling national debt. In doing so, the post-Cold War defence budget was at the forefront of generating savings. CAF personnel numbers were reduced to 60,000 , down from 75,000 and the budget was slashed by 25 percent over a four-year period, from $\$ 12$ billion to $\$ 9$ billion. That there was little to no public outcry was largely the result of the equally deep cuts being made to social and health transfers to the provinces and the loss of federal services. ${ }^{88}$ None of this is to say that there are not limits to how low Canadian defence funding can go. Leuprecht and Sokolsky cite the example of the Chrétien government maintaining a minimal core operational capability in the face competing pressures to

\footnotetext{
${ }^{85}$ Perry, “A Return to Realism: Canadian Defence Policy after the Great Recession,” 340.

${ }^{86}$ Ibid., 341-342.

${ }^{87}$ Philippe Lagassé and Paul Robinson. Reviving Realism in the Canadian Defence Debate (Kingston, ON: Centre for International Relations, Queen's University, 2008), 3.

${ }^{88}$ Sokolsky, Joel J. 1995. Canada, Getting it Right this Time: The 1994 Defence White Paper. Strategic Studies Institute, Carlisle Barracks (Penn.), U.S. Army War College Sixth Annual Strategy Conference, April 26-28, 1995, 40.
} 
drastically cutback federal spending in the 1990s as necessary in order to maintain participation in both UN and NATO councils. ${ }^{89}$ Faced with these dual alliances and secure geostrategic position Canadian defence planners have to contend with providing a robust and effective CAF without defence being a major political priority. ${ }^{90}$ How this would be accomplished relies less on strategic calculators and more on fiscal considerations, with the political executive determining "how much is enough" for defence spending. ${ }^{91}$

A similar episode was repeated in 2009 , following the onset of a worldwide recession that began the previous year. The Harper Conservative government, despite making defence a priority, sought to return to a balanced budget from its $\$ 47$ billion stimulus package by freezing defence spending and pushing procurement projects off into the future. A 2015 report on these alterations to the defence budget, post-2008 global economic crisis, found that $\$ 32.2$ billion in procurement dollars were lost and 400 personnel from DND's Material arm were cut. Similarly, the CAF's operational readiness was dramatically reduced with the Canadian Army parking half of its wheeled vehicles in 2013 and the Royal Canadian Air Force reducing flying hours by 25 percent. ${ }^{92}$ As in the 1990s, there was little public backlash for the Harper government when it took these actions.

Therefore, the record for governments adhering to a promise of increased defence spending remains poor. In 1975, Pierre Trudeau's government announced the Defence Structure Review, an attempt to bridge the capability gaps that had arisen over the preceding decade due to

\footnotetext{
${ }^{89}$ Leuprecht and Sokolsky, "Defense Policy 'Walmart Style'," 541-562.

${ }^{90}$ Robert W. Murray and John McCoy, "From Middle Power to Peacebuilder: The Use of the Canadian Forces in Modern Canadian Foreign Policy," American Review of Canadian Studies 40, No. 2 (2010): 176.

${ }^{91}$ Sokolsky, 1989, 13, 19-20.

${ }^{92}$ Dave Perry, "A Primer on Recent Canadian Defence Budgeting Trends and Implications," School of Public Policy Research Papers 8, No. 15 (2015): 2-3, 5.
} 
defence cuts and inflation. While this government committed itself to NATO's three percent in real growth annual defence spending target, it rarely attained that goal in the face of continuing inflation increases and other non-military program demands. ${ }^{93}$ Not to be outdone, in 1984 Brian Mulroney's Progressive Conservative government also pledged to increase defence spending, this time by six percent per year. But by 1989 defence spending had only grown between two and three percent per annum before deep cuts were implemented following the April budget as the Mulroney government tried to contain the federal deficit. ${ }^{94}$

As noted in Chapter One, the Conservatives came to power in 2006 on the promise of renewing the CAF under their "Canada First" defence strategy. Shortly after taking office, the Conservatives initiated what Richter terms the "largest concentration of planned defence procurement projects in Canadian history". In addition to raising troop levels back up to 75,000 from 60,000, the new government would purchase Joint Support Ships, tactical and strategic airlift, and medium support trucks. These plans would later be encapsulated within the 2008 Canada First Defence Strategy (CFDS): a document that outlined some 20 years of defence spending, with budget increases of two percent per annum. In the end, the ambitious funding plans were cast aside as the government grappled with cutting the deficit in the aftermath of the 2008 global financial crisis. Defence was eventually singled out for some 20 percent of all planned spending cuts between 2012-2015. ${ }^{95}$ The consequence of these cuts equated to an

\footnotetext{
${ }^{93}$ Andrew Richter, "Forty Years of Neglect, Indifference, and Apathy: The Relentless Decline of Canada's Armed Forces", in Handbook of Canadian Foreign Policy, eds. Patrick James, Nelson Michaud, and Marc J. O'Reilly (Oxford: Lexington Books, 2006), 58.

${ }^{94}$ William L. Dowdy, "The Canadian Navy: Torpedoed Again", Armed Forces \& Society Vol. 16(1) (1989), $105-$ 106.

${ }^{95}$ Andrew Richter, "A Defense Renaissance?" American Review of Canadian Studies 43, no. 3 (2013): 425-426, $427,431$.
} 
underfunded CFDS procurement plan, much like its 1987 White Paper and 1975 Defence Structure Review predecessors.

A major consequence of episodes like these is that medium to long-term funding is unpredictable and at the mercy of the whims of the prime minister and cabinet of the day. Thus, planning for MCPs that typically involve a ten to fifteen-year timeline remains a challenge. If and when budgets become incapable of bringing a project to fruition, capability-cost trade-offs are the end result. ${ }^{96}$ The post-war period is littered with examples of this dilemma. In 1970, after completing a multi-million dollar refit, the CAF parted with its only aircraft carrier, HMCS Bonaventure, in order to come up with the necessary monies to build four Iroquois-class destroyers. ${ }^{97}$ In 2014, the navy paid off its two remaining Auxiliary Oil Replenishment (AOR) ships, HMCS Preserver and HMCS Protecteur, plus two of its three remaining Iroquois-class destroyers, in order to reallocate tight defence dollars from maintenance towards future procurement projects. And in some cases a project is cancelled outright in order to generate savings, like the army's Close Combat Vehicle in 2013.

The Department of National Defence and the CAF have tried to maximize their budget by engaging in outsourcing. Until the acquisition of C-17 and C-130J strategic and tactical airlift planes in 2007 and 2010, respectively, the CAF relied upon contracting Ukrainian planes to transport troops and equipment overseas. During the height of combat operations in Afghanistan in 2007, the CAF was paying out $\$ 11$ million per month for such rentals. Before acquiring six leased CH-147D Chinooks from the U.S. in 2008, and outright purchasing fifteen new CH-147F

\footnotetext{
96 Sjolander, Claire Turenne. "Cashing in on the "Peace Dividend"." In How Ottawa Spends 1996-1997, edited by Gene Swimmer, 253-281. Ottawa: Carleton University Press, 1996, 254, 273.

97 Plamandon, "Equipment Procurement in Canada and the Civil-Military Relationship: Past and Present", xiiii, 9, $10,29$.
} 
Chinooks from Boeing in 2013, the CAF rented up to six Mi-8 helicopters with crews from the company Sky-Link Aviation to sustain forward operating positions in Afghanistan. Similarly, the CAF relied upon contractors to maintain bases in Bosnia and Afghanistan to generate savings from having military personnel engage in support functions. Perry contends that such contracting has been "highly successful" as it alleviated stress on CAF personnel and saved money from having to recruit, staff, and deploy support occupations. ${ }^{98}$

The introduction of accrual accounting in the early 2000s was also supposed to help avoid the worse effects of oscillating budgets. For defence procurement, accrual accounting involves amortizing capital assets - like MCPs - over the time period in which they are planned to be used. While Parliament allocates funding, known as 'investment cash', to cover the actual purchasing cost of a MCP, this is not considered a part of DND's budget ceiling. Instead, "the cost is now charged to DND over a longer period of time as a depreciation expense". ${ }^{99}$ The use of accrual accounting was hypothesized to limit the ability of the government to re-allocate money away from a MCP. ${ }^{100}$ However, the effect of accrual accounting has been mixed. Governments now simply delay their annual allocations to the project envelopes which leads to a real cost downsizing of the project budget because of inflationary pressures. At this point capability-cost trade-offs are almost inevitable unless more money is injected into a project's budget. Similarly, when cuts to DND's overall budget are made, the department attempts to protect its procurement projects by finding savings elsewhere, usually by cutting personnel, which consume 47 percent of the budget, training or operational readiness (e.g. cutting the fuel

\footnotetext{
98 David Perry, “The Privatization of the Canadian Military,” International Journal 64, no. 3 (2009), 688-692.

${ }^{99}$ Binyam Solomon and Craig Stone, "Accrual Budgeting and Defence Funding: Theory and Simulations", Defence and Peace Economics 24, no. 3 (2013), 211-212.

${ }^{100}$ Perry, "A Return to Realism”, 347.
} 
allowance for equipment, buying less spare parts, etc....). ${ }^{101}$ Solomon and Stone remind us that a key reason the mixed impact of accrual accounting is that "budget decisions are inherently based on political choice" and that without alterations in strategic management and defined links to outcomes and outputs, the supposed benefits of accrual accounting will be undermined. ${ }^{102}$ This would indicate that even with the adoption of accrual accounting practices, defence acquisitions are still vulnerable to the fiscal whims of the political executive.

Other commentators have suggested that savings could be obtained and planning stabilized if the CAF developed niche capabilities instead of trying to obtain a general purpose military - long the goal of Canadian defence planners. ${ }^{103}$ Janice Stein has even argued that Canada's collective defence arrangements with NATO and the United States allow for specialization and possible defence co-ordination, although no government seems willing to go down this route. ${ }^{104}$ The impact of geography and alliances means that Canada's defence capabilities are "a mile wide and an inch deep". However, Canada cannot replicate the Dutch and Belgian approach of specializing and integrating with the Germans and the French. The tripriorities of defending Canada, North America, and participating in international peace and security missions prevents this. Domestic search and rescue demands alone, like the Fixed-Wing Search and Rescue plane, require expeditionary-like capabilities and infrastructure. Instead, Canada must develop expensive, but limited capabilities. ${ }^{105}$

\footnotetext{
${ }^{101}$ Ibid., 355.

${ }^{102}$ Solomon and Stone, "Accrual Budgeting and Defence Funding”, 212.

${ }^{103}$ Peter Jones and Philippe Lagassé, "Rhetoric Versus Reality," Defense \& Security Analysis 28, no. 2 (2012): 141; Richter, Andrew. "Strategic Ambitions and Fiscal Realities: Give the Navy Priority", Policy Options (April 2002): 27-28, 30 .

${ }^{104}$ Stein, Janice Gross. "Ideas, even good ideas, are not enough: changing Canada's foreign and defence policies." International Journal 50 (Winter 1994-1995): 65.

${ }^{105}$ Alexander Moens. Canada's Defence Policy Renewal: Broad Capabilities in an Allied and Partners Framework. (Ottawa: Conference of Defence Associations Institute, 2016), 2-3.
} 
The intersection of budgets, military missions, and government programs naturally crosses into the realm of public opinion, something that elected governments are very aware of (e.g. the 2003 U.S. led invasion of Iraq). ${ }^{106}$ Given Canada's benign security environment, governments realize that any increase in defence spending will inevitably be compared to spending on more popular priorities like healthcare and social transfers. ${ }^{107}$ The sum impact of this dynamic translates into defence usually being a low government priority; "public support for defence spending has been inherently soft in Canada". ${ }^{108}$ As Middlemiss and Sokolsky contend, public opinion defines the parameters in which the political executive operates when it comes to defence policy and procurement. ${ }^{109}$ It is notable that with the exception of prime minister John Diefenbaker's handling of the nuclear weapons acquisition in 1963 no Canadian government has "risen or fallen on defence issues." 110 In attempting to understand how public opinion constrains defence policy it has been said that observers need to go as far back as the 1960s to identify a shift in Canadian attitudes and to their consequent contribution to "the lengthy process of military decay". ${ }^{111}$ Dowdy, in reflecting upon the failure of the nuclear submarine acquisition in 1989, wryly noted that:

Canadians do not hold the professional military in high esteem except when it is needed. They prefer day care over destroyers, and socialized medicine over submarines. ${ }^{112}$ Subsequent scholarship has provided a more nuanced understanding of why such a shift has occurred. Middlemiss and Sokolsky state that Canadians are, by and large, disconnected from

\footnotetext{
${ }^{106}$ Richter, “A Defence Renaissance?”, 439.

${ }^{107}$ Stein, "Ideas, even good ideas, are not enough", 61.

${ }^{108}$ Wu, Terry and Ross Fetterly. "Canadian Defence Policy: An Analysis." Canadian Public Policy 16, no. 2 (1990): 168.

${ }^{109}$ Middlemiss and Sokolsky, Canadian Defence: Decisions and Determinants, 121.

${ }^{110}$ Ibid., 113.

${ }^{111}$ Richter, "Forty Years of Neglect, Indifference, and Apathy", 51.

${ }^{112}$ Dowdy, "The Canadian Navy: Torpedoed Again", 111.
} 
their military because of the immense size of the country's territory. There are only 38 Canadian Forces Bases and Stations located in Canada, many of which are in isolated and rural settings (e.g. CFB Goose Bay in Labrador or CFS Alert, in the Nunavut). ${ }^{113}$ Likewise, with a relatively small all-volunteer force of 68,000 regulars and 26,000 reserves, few Canadians have personal contact with the CAF. It should come as no surprise then that few of Canada's members of Parliament have military experience and thus, given the absence of existential threats, do not see it as a priority to educate Canadians or themselves on defence matters.

This is not to say that the public is completely apathetic on defence. There is an acceptance towards the "need for an adequately armed military establishment to carry out Canada's international defence responsibilities". Moreover, issues surrounding nuclear weapons have long proven a lightning rod for mobilising interest groups and political pressure in Canada, as witnessed by the Ballistic Missile Defence debate in 2004-05. The same variables that feed into nuclear weapons matters - "latent anti-Americanism" and a sense of moral superiority - also drive the need in many Canadians for their country to be known as a peacekeeping nation. ${ }^{114}$ Although Douglas Bland refers to the public's belief in peacekeeping as bordering on a "national myth", it is not the purpose of this dissertation to debate the subject only to acknowledge the term's resonance with the wider Canadian public. ${ }^{115}$ In procurement terms, the public's "enthusiasm for peacekeeping" has meant that successive governments have found it difficult to say 'no' to requests from the UN and, NATO, for contributions to international missions. In the 1990s fully 25 percent of Land Command's regular personnel were deployed on such overseas

\footnotetext{
${ }^{113}$ See Department of National Defence, "Canadian Armed Forces Bases, Wings and Selected Installations and Sites Across Canada", Reports on Plans and Priorities 2013-14 (Ottawa: 2013).

${ }^{114}$ Middlemiss and Sokolsky, Canadian Defence: Decisions and Determinants, 114-121.

${ }^{115}$ Bland, "Canada and Military Coalitions: Where, How, and with Whom?”, 19.
} 
missions putting great strain on the CAF's equipment and personnel. ${ }^{116}$ The Harper government may have foresworn UN peacekeeping (as did most Western governments after 9/11), but it was equally willing to participate in NATO and U.S.-led coalition missions as its Liberal predecessors.

There exists a degree of support for the CAF to carry out sovereignty operations (e.g. Arctic Ranger patrols) and search and rescue missions due to Canadians' emotional concerns over sovereignty, especially in the Arctic but also over offshore resources in the Atlantic and Pacific. The challenge of course is figuring out how to translate this concern into procurement decisions while also contending with determining which roles the CAF can play without duplicating those actions being performed by the Departments of Fisheries and Oceans and the Canadian Coast Guard. ${ }^{117}$ The plan to purchase nuclear submarines in the 1987 White Paper was partly based on sovereignty concerns but the project failed over 'sticker shock' costs, public opposition to nuclear technology, and deteriorating federal financial health.

Defence policy of course is hardly immune from Canada's perennial federal-provincial squabbling. Provinces have typically played only a peripheral role in defence policy with two exceptions, base closures and procurement. With the former, provincial governments tend to pushback against base closures given the annual injection of millions of dollars in disposal income and contracts to local economics often located in economically depressed areas. When the Mulroney government made the decision in 1989 to close CFB Summerside in Prince Edward Island, Charlottetown put pressure on Ottawa to lessen the impact. Eventually, the federal government paid out $\$ 125$ million in economic development money, transition grants,

\footnotetext{
${ }^{116}$ Cheeseman, Graeme. "Canada's Post-Cold War Military Blues and the Lessons for Australia." Pacifica Review 13, no. 2 (2001): 184; see also, Richter, "Forty Years of Neglect, Indifference, and Apathy", 64.

${ }^{117}$ Middlemiss and Sokolsky, Canadian Defence: Decisions and Determinants, 168.
} 
and the building of the GST tax centre to the community to mollify the fallout of the closing. ${ }^{118}$ In the case of CFB Chatham in New Brunswick, local backlash saw both the Trudeau and Mulroney governments backtrack from a planned closure originally announced in 1982. In response, both governments kept the base open by relocating a CF-5 tactical fighter squadron, low-level air-defence training school, and a mobile anti-aircraft battery from other bases. The goal was to keep CFB Chatham's $\$ 30$ million per year contribution to the area's economy continuing. ${ }^{119}$ Such provincial pressures become an added constraint on defence planners when savings are required without impacting capital projects and operations. ${ }^{120}$

Provincial governments are also concerned with industrial offsets and Ottawa's IRB/ITB policies. First introduced with the Long Range Patrol Aircraft project in 1976, the use of IRBs has seen the emergence of interprovincial competition over procurement contracts. This was pronounced over the purchase of the CF-18 in 1979-80. ${ }^{121}$ It was also evident with the selection of shipyards for the National Shipbuilding Procurement Strategy in 2010-2011. Consequently, it is rare that MCPs are not subject to public bickering and lobbying:

Virtually no major weapons-acquisition program is now exempt from some sort of highly publicized intrusion by provincial politicians, often aided and abetted by their regional counterparts at the federal level as well as by defence firms located within their jurisdictions. $^{122}$

\footnotetext{
118 Savoie, Donald J. "Summerside: Revisiting the Base Closure." Canadian Journal of Regional Science 18, no. 1 (1995): 57-76.

${ }^{119}$ Middlemiss and Sokolsky, Canadian Defence: Decisions and Determinants, 129.

${ }^{120}$ Bland, "A sow's ear from a milk purse", 169.

${ }^{121}$ Middlemiss and Sokolsky, Canadian Defence: Decisions and Determinants, 126-127.

122 Ibid., 128.
} 
It has been suggested that one way to dilute the excesses of regionalism is to implement a clearly defined defence industrial policy that allows for the government to justify defence procurement expenditures. ${ }^{123}$ It remains to be seen whether the 2014 Defence Procurement Strategy, a defence industrial policy of sorts, can mollify some of the worst excesses of procurement offsets. Such regional considerations often halt efforts by the DND and CAF to rationalize expenditures and acquire the equipment necessary for the military's needs as the cost of IRBs/ITBs usually translates into higher premiums with bidders building the additional cost of doing business in Canada into their bids. ${ }^{124}$

\section{Bringing It All Together}

With internal and external policy pressures, multiple departments, statutes and regulations, Canada's defence procurement system and process is a labyrinth. It is no surprise, as the following four case studies will highlight that all the issues and organizations identified in this chapter play, to some degree, a role in shaping the outcomes of a Major Crown Project. This dissertation will address the question of how much of a role the political executive plays in contributing to delaying MCPs.

\footnotetext{
${ }^{123}$ Stone, Craig. "Canada needs a defence industrial policy.” International Journal 63, no. 2 (2008): 342.
}

124 Jones and Lagassé, "Rhetoric versus reality", 145. 


\section{Chapter 3 - Joint Support Ships}

\section{Introduction}

If asked to name the two most prolonged defence procurement projects in Canadian history, the replacements for the CF-18 fighters and Sea King helicopters would come out on top. However, if asked to include a third project, then the attempt to replace the Royal Canadian Navy's (RCN) Auxiliary Oil Replenishment (AOR) ships would follow closely behind these. Identified as a maritime procurement priority by the Department of National Defence (DND) in the early 1990s, and then by the Paul Martin cabinet in 2004, the Joint Support Ship (JSS) program has yet, as of 2018 , to begin construction. Initially pegged to deliver three ships, and now two, the first vessel will not hit the water until 2021 - a time lapse of nearly three decades in total, and nearly seven years after the navy's AORs were retired from service. ${ }^{1}$

The AOR ships, or 'oilers', are the lifeblood of the navy's fleet. Such ships provide the fuel, ammunition, spare parts, and helicopter support necessary for frigates, destroyers, and submarines to undertake long-range missions without returning to port. Crucially, they are at the core of a naval task force, allowing formations of three or more of Canada's ships to deploy as an independent, self-sustaining group to areas where ports maybe out of reach or are in hostile waters. ${ }^{2}$ The navy had relied on three such vessels since the early 1970s, the HMCS Provider, and the two ships of the Protecteur-class, HMCS Protecteur and HMCS Preserver. The Provider, built in 1962, was the first to be removed from service, in 1998, while the latter vessels, built in 1968-70, operated until 2014-15 when it was no longer financially viable or safe

\footnotetext{
${ }^{1}$ David Pugliese, "DND says delay on delivery of first Joint Support Ship is several months." Ottawa Citizen, January 4, 2017.

2 Vice-Admiral Paul Maddison, then Chief of Maritime Staff and Commander of the Navy, testimony before the Standing House Committee on National Defence, December 6, 2011.
} 
to do so. But before the age and the pace of post-Cold War operational deployments had taken their toll on the AOR ships, Maritime Command began identifying the need to replace them in the early 1990s.

What became known as the Joint Support Ship project, and in 2013 the Queenston-class, went through two iterations. ${ }^{3}$ From 2004-2008, the first attempt resulted in a cancelled Request For Proposal (RFP). The second started in 2010 when the project became one of three major naval procurements to be included under the then named National Shipbuilding Procurement Strategy. The delays in bringing the project to fruition in its second guise saw the Harper government turn to a series of temporary measures, the most prominent being an unsolicited pitch from a Quebec shipyard in 2014. This resulted in a contract for converting a refitted commercial ship into a leased 'Interim' AOR ship until the JSS finally enter service in 20212022. This chapter will assess the JSS by examining the political executive's role from the JSS's early start in the Jean Chrétien (1993-2003) and Paul Martin (2003-2006) Liberal governments, when it was identified as a procurement project up to its still ongoing definition stage (the JSS has yet to reach project implementation). Table 3 below provides an overview of the key process milestones in the JSS project. The original dates established for advancing the project through the procurement process are compared to when they were actually achieved, or are planned to be achieved.

\footnotetext{
${ }^{3}$ Since this dissertation was written the ships have yet again been renamed: they are to keep their predecessors' names, Protecteur and Preserver as the Protecteur-class. See: Canada. Department of National Defence, "Joint Support Ships to be renamed Protecteur and Preserver". Accessed November 1, 2017: http://www.navymarine.forces.gc.ca/en/news-operations/news-view.page?doc=joint-support-ships-to-be-renamed-protecteur-andpreserver/j7oyseor.
} 


\begin{tabular}{|c|c|c|c|c|}
\hline \multicolumn{5}{|c|}{ Table 3 - JSS Project Milestones ${ }^{4}$} \\
\hline Stage & Original Date & 2008 & 2011 & Current Status \\
\hline Project Identification & 2003 & $\checkmark$ & $\checkmark$ & $\checkmark$ \\
\hline $\begin{array}{l}\text { Memorandum to } \\
\text { Cabinet }\end{array}$ & April 2004 & $\checkmark$ & June 2010 & $\checkmark$ \\
\hline Options Analysis & - & - & Fall 2009 & $\checkmark$ \\
\hline $\begin{array}{l}\text { Project Definition } \\
\text { (PPA) }\end{array}$ & November 2004 & $\checkmark$ & June 2010 & $\begin{array}{c}\text { Spring } 2017 \\
\text { (revised six times) }\end{array}$ \\
\hline $\begin{array}{l}\text { Project } \\
\text { Definition } \\
\text { Contract }\end{array}$ & December 2006 & $\checkmark$ & July 2010 & $\checkmark$ \\
\hline $\begin{array}{l}\text { Implementation } \\
\text { (EPA) }\end{array}$ & 2008 & $\begin{array}{c}\text { Project } \\
\text { Cancelled }\end{array}$ & February 2013 & 2018 \\
\hline First Delivery & 2012 & $\mathrm{~N} / \mathrm{A}$ & March 2013 & 2021 \\
\hline Final Delivery & 2016 & $\mathrm{~N} / \mathrm{A}$ & Spring 2018 & 2022 \\
\hline Project Close-Out & - & $\mathrm{N} / \mathrm{A}$ & Fall 2019 & 2022 \\
\hline
\end{tabular}

\section{Political Executive Decisions}

\section{a. The Early Years: 1994-2005}

The Jean Chrétien Liberal government was the first Canadian government to indicate the need for new AOR ships. That government's 1994 White Paper on Defence, officially endorsed by Cabinet, set out the country's first post-Cold War defence policy framework. ${ }^{5}$ The White Paper identified the need for Maritime Command to maintain a capability that went beyond simply refuelling ships at sea. The White Paper called for Maritime Command to acquire a "capability to sealift troops, equipment and supplies for multilateral operations". However, the White Paper did not spell out acquisition timelines or whether the ships would be built domestically or

\footnotetext{
${ }^{4}$ Dates come from a combination of the following sources: Canada. Treasury Board of Canada Secretariat. ARCHIVED National Defence - 2011-12 RPPS - Status Report on Transformational and Major Crown Projects. accessed July 15, 2017: https://www.tbs-sct.gc.ca/rpp/2011-2012/info/mcp-gpe-eng.asp\#jss-nsi; Canada. National Defence and the Canadian Armed Forces. 2017-18 Departmental Plan, "Status report on transformational and major Crown projects," accessed July 14, 2017, http://www.forces.gc.ca/en/about-reports-pubs-report-plan-priorities/2017status-report-on-transformational-and-major-crown-projects.page\#p8; Perry, 2015 Status Report, 42.

${ }^{5}$ Sokolsky, Canada, Getting it Right this Time, 11.
} 
acquired abroad nor did it specify the roles the ships would play - beyond stating that a future AOR would operate under a "multi-purpose combat capable" CAF. ${ }^{6}$

Moreover, given the tight fiscal climate at the time, with the Chrétien government cutting defence spending amid a focus on eliminating the federal deficit, there was no promise of when exactly these new AORs would be introduced or if money would be forthcoming to start the process of buying them. Instead, and in keeping with the emphasis on constraining costs, the White Paper specified that Maritime Command's oldest auxiliary oiler, the HMCS Provider, be kept in service beyond its intended decommissioning date of 1996. Implicit in this position was the need to buy as much as time as possible before the government proceeded to acquire a new replacement AOR fleet. ${ }^{7}$ None of this should come as a surprise as Chrétien had made it clear that defence and the CAF were not a priority policy area for him and his Cabinet. Chrétien spent the 1993 election partly campaigning on the promise to stop what he perceived as wasteful spending and controversially cancelled the Sea King replacement, the EH-101 helicopter, on his first day in office. Writing in his memoirs years later he derisively referred to the CAF as always wanting the latest, expensive equipment. ${ }^{8}$ Delaying the AOR replacements was much in keeping with the procurement practices of the 1993-2003 Liberal administration. Tellingly, the one major maritime acquisition initiated under Chrétien's tenure - the 1998 purchase of four ex-Royal Navy Upholder-class submarines - had its approval personally delayed for several years by the prime minister over the concern of possible negative public repercussions stemming from the $\$ 800$ million price tag to be spent during a time of fiscal belt-tightening. As has been detailed elsewhere, these approval delays forced the existing thirty-year-old Oberon-class submarines to

\footnotetext{
${ }^{6}$ Department of National Defence. 1994 White Paper on Defence (Ottawa: Department of National Defence, 1994), 35.

${ }^{7}$ Ibid, 35; Hobson, "Plain Talk: JSS Adrift in a Strategic Black Hole", p. 35.

${ }^{8}$ Chretien, Jean. My Years As Prime minister. Toronto: Vintage Canada, 2008, 79, 303.
} 
operate to the breaking point and left the Upholders, now the Victoria-class, sitting in corrosive saltwater for longer than necessary. ${ }^{9}$

In 2001, the Chrétien cabinet approved a shipbuilding policy that impacted all federal shipbuilding; but at the time this was difficult to ascertain because no ship projects had been sanctioned for construction. Then industry minister Brian Tobin released a document titled Focusing on Opportunities: A New Policy Framework for the Canadian Shipbuilding and Industrial Marine Industry. ${ }^{10}$ This policy framework, since encapsulated in PSPC's Supply Manual, stipulates that the procurement, refit and modernization of federal vessels, costing more than $\$ 25,000$, should be done on the basis of fostering a national competition among Canadian shipyards. In order for this policy to be effective, the available yards needed to have "the technical capability to perform the work" and ensure that the contingency costs of building a vessel domestically "are not unrealistic in relation to the total price". The Statement of Requirements (SOR) also have to be "sufficiently defined to permit assessment of competing bids by common standards" (i.e. no rigging in favour of one yard or a foreign yard). ${ }^{11}$ While ostensibly new, the policy was actually codifying what had long been standard federal practice. Since the Second World War, ships for the navy and coast guard were built domestically, the rare exceptions being large and/or complex vessels like submarines or aircraft carriers. The 2001 policy did however reaffirm the view that military procurement was first and foremost an economic development concern, and a matter of military capability, second.

\footnotetext{
${ }^{9}$ Canada. Parliament. House of Commons. Standing Committee on National Defence and Veterans Affairs, Procurement of Canada's Victoria Class Submarines, 38 ${ }^{\text {th }}$ Parliament, $1^{\text {st }}$ Session, 2005.

${ }^{10}$ Government of Canada. A New Policy Framework For The Canadian Shipbuilding and Industrial Marine Industry (Ottawa: Industry Canada, 2001).

${ }^{11}$ Canada. Public Services and Procurement Canada. "3.170. Shipbuilding, Repair, Refit and Modernization”, Supply Manual (31 October 2012): https://buyandsell.gc.ca/policy-and-guidelines/supply-manual/section/3/170 (Accessed 16 December 2016).
} 
The only other significant political executive decision impacting the AOR replacement during the Chrétien administration occurred in June 2003, and even then only in a limited way. With the HMCS Provider having been retired in 1998 and the remaining Protecteur class ships entering their fourth decade of service, Chrétien's minister of national defence, John McCallum, approved a limited expenditure for DND to establish a project office for what was now named the 'Afloat Logistics Sealift Capability' (ALSC) project, the formal DND designation for a new AOR replacement. With McCallum's approval, the project now officially had the resources to undertake engineering, logistics, and management support work. However, there is no indication that discussion on the ALSC went beyond McCallum's office. The project received no explicit endorsement from either the prime minister or cabinet and thus remained an internal DND concern, reflecting Chrétien's low-key approach on defence matters. ${ }^{12}$

Aside from McCallum's support, it would take the government of a new Liberal prime minister, Paul Martin, to move beyond the 1994 White Paper's position of restraint and facilitate a decision at the cabinet level on acquiring new AORs. Martin, Chrétien's former high-profile minister of finance, fought a multi-year political insurgency to unseat his boss. Having finally taken over the leadership of the governing Liberal party in December 2003, and thus becoming prime minister, Martin set out to differentiate himself from his predecessor. One of the areas his administration focused on was defence and foreign affairs. ${ }^{13}$

With the federal deficit eliminated and the treasury flush with cash, Martin sought to reequip the CAF. As one of two key maritime projects needing replacement (the other being the Sea King helicopters), the Martin cabinet approved the AOR replacement - rechristened the Joint

\footnotetext{
12 Bercuson, et al., An Opaque Window, p. 30.

${ }^{13}$ Paul Martin, Hell or High Water: My Life in and out of Politics (Toronto, McClelland \& Stewart, 2009).
} 
Support Ship project - in April 2004. ${ }^{14}$ That same month, the Martin cabinet approved funding for the JSS in their first budget: $\$ 2.1$ billion for three JSS ships and $\$ 800$ million for in-service support, over a twenty year period. At $\$ 700$ million per ship, the budget did cap some of the project's more ambitious earlier proposals (see section III) but the JSS would still be a significant undertaking if brought to fruition. With 1,500 metres of lane space for vehicles, Maritime Command would get a multi-capable ship beyond the standard AOR refuelling capability it was replacing. ${ }^{15}$ The JSS plan included "strategic sealift capability to allow it to deploy and sustain operations in support of government policy and enhancing Canada's capability for joint command and control of forces ashore". ${ }^{16}$ Moreover, the senior CAF leadership assured Martin government officials that the JSS price tag was adequate and that three ships could be bought, at under $\$ 3$ billion, for less than the cost of a new frigate. ${ }^{17}$ In November 2004, the JSS project went before the Treasury Board cabinet committee and was granted Preliminary Project Approval (PPA). Earmarked with $\$ 72.2$ million out of the $\$ 2.1$ billion budget, the JSS Project Office now had the resources and endorsement to proceed to the preliminary project definition stage. ${ }^{18}$ Shipbuilding firms would now be asked to proposed design plans for the project after which two would be selected to prepare finalized designs.

In April 2005, the Martin government further clarified its vision and roles for the JSS with the launch of a cabinet-approved defence policy, Canada's International Policy Statement,

\footnotetext{
${ }^{14}$ Confidential source, Telephone interview with the Author, January 22, 2017.

15 "The Joint Support Ship Project," Defense-Aerospace.com. accessed July 15, 2017: http://www.defenseaerospace.com/article-view/release/37340/canada-details-new-joint-support-ships-(apr.-19).html.

${ }^{16}$ Canada. Department of National Defence. Report on Plans and Priorities 2006-2007, 11; Hobson, "Plain Talk: JSS Adrift in a Strategic Black Hole", 36.

${ }^{17}$ Confidential source, Telephone interview with the Author, January 5, 2017; Confidential source, Telephone interview with the Author, January 22, 2017.

${ }^{18}$ Bercuson, et al., An Opaque Window, p. 31; Perry, 2015 Status Report on Major Defence Equipment Procurements, 42; Canada. Department of National Defence. Report on Plans and Priorities 2006-2007, 11-12.
} 
more commonly known as the Defence Policy Statement (DPS). The DPS became the first official federal defence policy since the 1994 White Paper. In contrast to its predecessor, the DPS was unique in that it situated defence and the CAF within an overarching foreign policy framework, the International Policy Statement (IPS), effectively synchronizing defence with foreign policy goals. Written by Martin's handpicked Chief of Defence Staff (CDS), General Rick Hillier, with the full support of defence minister Bill Graham, the DPS was Martin's attempt to further define his administration from Chrétien's. ${ }^{19}$ Several months earlier, in February 2005, Martin's second budget as prime minister witnessed a $\$ 13$ billion injection, over five years, into the defence portfolio. This money represented the largest promised expenditure on defence since the Pierre Trudeau government's 1975 Defence Structure Review. ${ }^{20}$ The 2005 budget money, along with the already allocated 2004 JSS money, underpinned the DPS's vision and capability requirements and ostensibly addressed a longstanding criticism of previous defence policies: that their ambition exceeded any financial commitment.

At its core, Martin's and Hillier's DPS aimed to integrate Maritime Command, Land Command, and Air Command, and special forces under a common command structure. Using the rubric of 'transformation' and 'jointness', the CAF would get a new command structure and fiscal resources to undertake a variety of integrated missions, predominantly in failed or failing states. For Maritime Command to meet this new objective, it required ships capable of five roles: to pre-position or deploy a Standing Contingency Task Force; to support army operations ashore; to provide a maritime command capability; to deploy drones; and to "sustain naval task group

\footnotetext{
${ }^{19}$ Martin, Hell or High Water; Hillier, A Soldier First.

${ }^{20}$ Martin Shadwick, "Defence and the International Policy Statement," Canadian Military Journal 6, No. 2 (2005):

83-84.; David McDonough, "Mind the 'gaps' in Canadian defence policy, even after Budget 2015,"

OpenCanada.Org. accessed July 16, 2017: https://www.opencanada.org/features/mind-the-gaps-in-canadian-

defence-policy-even-after-budget-2015/.
} 
operations worldwide" (the traditional AOR role). ${ }^{21}$ While the term Joint Support Ship, or JSS, is not invoked at all in the DPS, (and for some commentators this generated confusion as to whether the government was looking for a JSS and a separate amphibious capability), it is now widely regarded that the DPS was referencing the JSS project. ${ }^{22}$ However, the April 2005 announcement of the DPS was the last political executive involvement in the JSS by the Martin government before the federal election was called that November. The Martin government fell and was replaced in February 2006.

\section{b. The Early Harper Years (2006-2008)}

Like the Martin Liberals, in the 2005-2006 election the Stephen Harper Conservatives positioned defence and the CAF as a policy issue in order to differentiate themselves from their opponents. Unlike the Liberals though, the Conservatives did not discuss the JSS project as a part of their 'Canada First' defence policy platform - likely on the grounds that it was a project too closely identified with the Martin team. ${ }^{23}$ During the 2005-2006 election, the Conservatives emphasized a more continental and Arctic-focused defence policy. Written by retired army general, Gordon O'Connor, the 'Canada First' plan predicated a strengthened maritime presence in the country's north with "three new armed naval heavy icebreakers in the area of Iqaluit". ${ }^{24}$

Upon coming to power in February 2006, the Harper government ordered a freeze on all existing defence procurement projects pending a review. During this review, at least publicly, there remained uncertainty on whether the JSS and its Martin-era Defence Policy Statement prescribed expeditionary role fit into the Harper government's plans. No Conservative Cabinet

\footnotetext{
${ }^{21}$ Canada. National Defence and the Canadian Armed Forces. Defence Policy Statement (Ottawa: 2005).

22 Shadwick, "Defence and the International Policy Statement", 83-84.

${ }^{23}$ Liberal Party of Canada, Securing Canada's Success (2006), 73.

${ }^{24}$ Martin Shadwick, "Defence and the Conservatives", Canadian Military Journal 7, no. 1 (2006): 73
} 
minister would comment on it. In one of his first major speeches as the new Minister of National Defence, Gordon O'Connor, at the Conference of Defence Associations' Institute annual Ottawa Conference on defence, failed to mention the JSSs, having instead emphasized the Canada First campaign plans for Arctic maritime capabilities. ${ }^{25}$ The procurement freeze initiated by the new government slowed down the JSS project so much so that by April 2006, DND and CAF officials were considering a less ambitious JSS design, possibly opting for "less expensive commercial tankers to refuel navy ships at sea" and purchasing a separate fleet of amphibious ships. $^{26}$

With the money having been committed in the 2004 budget and the project having entered the preliminary definition stage, the Harper government likely had little choice but to stay with the JSS unless they face political embarrassment and costly litigation from the three consortia engaged in definition work (the Trudeau Liberals found themselves in a similar position with the Harper cabinet approved Interim Auxiliary Oil Replenishment ship soon after their election win in 2015). Consequently, the JSS went before Cabinet for approval in June as a part of a package of 'Canada First' defence procurement projects which were unveiled later that month. Known as the 'Big Five', the JSS, along with four strategic and seventeen tactical lift aircraft, 2,300 medium support logistic trucks (see Chapter Four), and sixteen medium-to-heavy lift helicopters, were announced on June 26, 2006 as part of a \$17 billion procurement package. All five projects were holdovers from the Martin government, having received their funding in

\footnotetext{
${ }^{25}$ Shadwick, "Defence and the Conservatives", 73

${ }^{26}$ Pugliese, David. "Military reconsidering big-ticket spending priorities: Giant long-range transport planes may be back on table." The Ottawa Citizen, April 15, 2006, A3.
} 
budgets 2004 and 2005, respectively, but with the latter four having failed to get Cabinet approval before the election. ${ }^{27}$

While the Conservatives endorsed the JSS they reframed the ships' role from supporting the Martin government's DPS overseas expeditionary plans, to becoming the Canada First domestic focus of "enhance[ing] the Canadian Forces' ability to safeguard Canada's domestic maritime security and sovereignty". Yet the joint announcement between defence minister O'Connor and industry minister Maxime Bernier also restated the four Martin-era JSS capabilities of being able to resupply ships at sea, perform sealift, deploy with task forces, and support ground forces ashore. In contrast to the brief mention found in the Liberals' 2004 JSS announcement, the Conservatives' put more weight into the JSS's industrial benefits: industry minister Bernier proclaimed that "Canada's new government will ensure that this project delivers maximum high-quality industrial benefits to Canadians" and that the domestic shipbuilding industry was "well-positioned to play a significant role" in the ships' building. The Conservative ministers declared that the first ship was slated for delivery to the navy in $2012 .{ }^{28}$

Another major political involvement in the JSS occurred sometime in 2006-2007 when the Harper government made the decision to reaffirm the 2001 shipbuilding policy framework established by the Chrétien government. Likely due to the optics of a Conservative government endorsing a Liberal policy, there was no public statement. Writing in 2016, former ADM for Procurement in PSPC, Tom Ring, argued that the Harper government was guided by two considerations in adopting the 2001-based approach to domestic shipbuilding: First, the Harper

\footnotetext{
${ }^{27}$ Hillier, A Soldier First, 387-427; Canada. Department of National Defence and the Canadian Armed Forces. DND News Release. "'Canada First' Defence Purchases - A Commitment to Canadians”, June 29, 2006.

${ }^{28}$ Canada. Department of National Defence and the Canadian Armed Forces. DND News Release. "'Canada First' Defence Purchases - Joint Support Ship”, June 26, 2006.
} 
government, like its predecessors, wanted to "ensure that the expenditure of tens of billions of dollars of taxpayers' money return as much economic value as possible"; and second, it recognized that industrial policies are an accepted international practice when it comes to major defence procurements. ${ }^{29}$ Delivering military capabilities were clearly not the priority.

The last political executive level involvement with the JSS project for 2006 came on 1 December. Then minister of PSPC, Michael Fortier, awarded two project definition contracts to Germany's TKMS and Canada's SNC-Lavalin Profac. The project had now moved firmly into the definition analysis stage of the procurement process. Between these two firms one design would be selected for the JSS. ${ }^{30}$ Beyond announcing the award there was no indication of any more political executive level involvement with the JSS until 2008. Earlier that year, the Conservatives approved of an increase to the total JSS budget: $\$ 16$ million to accommodate for design changes related to the government's earlier acquisition of Leopard II tanks for the army in Afghanistan and another $\$ 44$ million to account for inflationary pressures. Total budgeted JSS expenses now stood at just under $\$ 3$ billion. ${ }^{31}$

In May 2008 the Conservatives unveiled their own cabinet-approved defence policy, the Canada First Defence Strategy (CFDS). Despite its prominent fixture in the June 2006 Canada First announcement, the JSS was now nowhere to be found in the CFDS's chart of existing and new major procurement projects. ${ }^{32}$ Moreover, in contrast to the Martin government's 2005

\footnotetext{
${ }^{29}$ Ring, Tom. The National Shipbuilding Procurement Strategy: How did we get to where we are now? Ottawa: Canadian Global Affairs Institute, 2016, 2; Canada. Office of the Auditor General of Canada. "Chapter 3: National Shipbuilding Procurement Strategy", Report of the Auditor General of Canada. Ottawa: Fall 2013, 5.

${ }^{30}$ Shadwick, Martin. “The Joint Support Ship Revisited." Canadian Military Journal 11, no. 1 (2010): 63.

${ }^{31}$ Canada. Department of National Defence. Major Crown Projects: Joint Support Ship (JSS) 2008-2009. Ottawa: 2008.

${ }^{32}$ Canada. National Defence. "'Canada First" Defence Strategy Procurement. Ottawa: Department of National Defence, 2008, 12.
} 
Defence Policy Statement, the CFDS did not "define the navy's specific role or its priorities". 33 Itself largely a repacking of previously announced projects, it became clear that even a month after its release, the CFDS's much publicized twenty-year defence spending plan was insufficient in the face of such a large number of Major Crown Projects needing to be acquired in a five-year window. ${ }^{34}$ While not publicly acknowledged, word had been percolating around senior government circles since late 2007, and certainly by March 2008, when industry bids were submitted, that the JSS budget was simply not affordable. ${ }^{35}$ It is within this context that the Harper government would cancel the first iteration of the JSS.

Amid the public discussions on the affordability of DND's procurement plans the PSPC minister, Christian Paradis, suddenly announced on August 22, 2008 that the RFP for the JSS project was cancelled, thereby forcing a restart of the project and a return to the options analysis phase. ${ }^{36}$ Its estimated that TKMS and SNC-Lavalin, the two companies who had developed designs for the JSS project, lost between $\$ 20$ and $\$ 30$ million on preparing their bids for this RFP $\cdot{ }^{37}$ Notably, the JSS was not the only casualty that day; the RFP for the Canadian Coast Guard's (CCG) \$750 million Mid-Shore patrol vessels was also terminated. According to a short statement on the cancellations, minister Paradis stated that both projects "were significantly over the established budget provisions" and were therefore not compliant with the "basic terms of the Request for Proposals". ${ }^{38}$

\footnotetext{
${ }^{33}$ Hobson, "Plain Talk: JSS Adrift in a Strategic Black Hole", 36.

${ }^{34}$ Sloan, Elinor. "Stretched to the breaking point." National Post, June 17, 2008, A12.

${ }^{35}$ Senior Government Official, Interview with the Author, September 25, 2016.

${ }^{36}$ Senior Government Official, Confidential interview with the Author, September 23, 2016; Pugliese, David.

"Ottawa cancels 'priority' navy contracts." Ottawa Citizen, August 23, 2008, A5.

${ }^{37}$ Confidential Source, Telephone interview with the Author, January 5, 2017.

${ }^{38}$ Canada. Public Services and Procurement Canada. "Bidders fail to meet budget requirements." PSPC News Release, August 22, 2008.
} 


\section{c. The Later Harper Years (2008-2015)}

Among senior political and bureaucratic figures alike, the failures of the JSS and Mid-Shore patrol RFPs were seen as a "come-to-Jesus-moment" for all of the Harper government's shipbuilding plans. ${ }^{39}$ The JSS's costing was never fully disclosed after the RFP cancellation but within government it was thought that the 2004-2008 JSS budget had to be doubled in order to meet the original RFP's SOR. ${ }^{40}$ Following the August announcement, the minister of defence ordered a review into the project's failure.

The review was carried out by a National Shipbuilding Procurement Strategy (NSPS) Office through 2008 and 2009. Composed of representatives from DND, PWGSC, and IC, the NSPS Office recommended a complete overhaul of planned federal shipbuilding for vessels weighing over 1000 tonnes under the framework of a National Shipbuilding Procurement Strategy (now known as the National Shipbuilding Strategy, or NSS). ${ }^{41}$ The Harper government later endorsed the review's conclusions and approved the NSS when it went before cabinet in June 2010. Given the public furor surrounding the Auditor General's report into the failed attempt to buy the F-35, prime minister Harper personally ordered his cabinet ministers and senior bureaucrats to "bulletproof" the NSS process from political interference, whether real or perceived.

In doing so, the prime minister transferred much of the NSS's decision-making and leadership responsibilities to the bureaucracy with the creation of a Deputy Ministers Secretariat (DMS) to oversee the project. Reflecting the political executive's loss of trust in DND over the

\footnotetext{
${ }^{39}$ Subject Matter Expert \#1, Confidential interview with the Author, October 5, 2016.

${ }^{40}$ Confidential source, Telephone interview with the Author, January 27, 2017.

${ }^{41}$ Office of the Auditor General of Canada, National Shipbuilding Procurement Strategy, 12.
} 
fallout of the F-35, the DM for PSPC was assigned the lead role on the DMS, with a NSS Secretariat housed in PSPC..$^{42}$ The DMS was composed of the DMs of PWGSC, IC, DND, and Fisheries and Oceans. Under this governance model, the DMs were tasked with carrying out a process of identifying and selecting two shipyards to build one of two 'packages': $\$ 35$ billion worth of combat vessels for the navy over 30 years and $\$ 8$ billion worth of non-combat vessels for both the navy and Coast Guard. The JSS was lumped in with the latter. The DMS would then select the winning yards, subject to third party review and an internationally-hired 'fairness' monitor. As per his instructions and the NSPS structure, prime minister Harper was only advised of the decision an hour before the bureaucrats made a public announcement. ${ }^{43}$

While baring some similarities to the Pierre Trudeau government's New Fighter Aircraft procurement structure, Harper's NSPS decision represented a major break from the past in both its governance model and attempt to rationalize the shipbuilding sector in Canada. However, it also contributed to lengthening the time it took to acquire the JSS. The 2008-2009 review left the restarted JSS in the options analysis stage. Movement to project definition and eventual implementation had to wait until the planned NSPS received cabinet approval, which occurred in June 2010; a week later the restarted JSS went before the Treasury Board cabinet committee where it was approved. ${ }^{44}$

The options approved by vabinet this time represented a break with the earlier JSS effort. For one, the project's budget was increased only from $\$ 2.1$ billion to $\$ 2.6$ billion. As noted earlier, estimates from the failed 2008 RFP indicated that a budget double that figure was

\footnotetext{
${ }^{42}$ Senior Government Official, Confidential interview with the Author, September 23

${ }^{43}$ Dan Ross, then-Assistant Deputy Minister (Materiel), testimony before the Standing Committee on National Defence, April 1, 2010; Office of the Auditor General of Canada. National Shipbuilding Procurement Strategy, 12. ${ }^{44}$ Perry, 2015 Status Report on Major Defence Equipment Procurements, 42.
} 
necessary to acquire the three ships the RCN and DND thought were needed to meet Canada's naval needs. The Harper government though only added enough money to cover the impact of inflation and project management expenses stemming from the two years the project spent on hiatus between $2008-2010 .{ }^{45}$ Fixed in nominal dollars, meaning that the government was not going to make any more adjustments for inflation, the new JSS budget came with the realization that only two ships, with the option of a third (if savings were generated) could actually be affordability purchased and even then, with significant reduction in capabilities from the 20042008 iteration. Doubt persisted as to whether the $\$ 2.6$ billion would even translate into two ships, a point made clear in a 2013 Parliamentary Budget Officer report which recommended that a budget of at least $\$ 3.18$ billion was needed to purchase two ships. ${ }^{46}$ Tellingly, considering the problems connected to the indigenous statement of requirement in 2004-2008, the new JSS was now to be based on an existing off-the-shelf design, or a comparable, equal in cost, domestic design. The adherence to building domestically, this time under NSPS, had the effect of excluding off-the-shelf purchases from overseas. This meant that the government bypassed the idea of purchasing the Dutch Karel Doorman - a ship that met many of the original 2004-2008 RFP's requirements - even though DND had dispatched a retired admiral to solicit information from a Dutch shipyard on possible overseas builds in $2008 .{ }^{47}$ Opting to go with the JSS build in Vancouver, furthered delays as Seaspan had to upgrade its facilities and hire personnel (see Section III).

\footnotetext{
${ }^{45}$ Canada. Office of the Auditor General of Canada. National Shipbuilding Procurement Strategy. Ottawa: Fall 2013, 19.

${ }^{46}$ Canada. Office of the Parliamentary Budget Officer. Feasibility of Budget for Acquisition of Two Joint Support Ships. Ottawa: 2013, 1.

${ }^{47}$ Petrolekas, George and David Perry. "Buy this ship." The National Post, September 26, 2013; Pugliese, David.

"DND under fire for scoping out Dutch shipyard." The Ottawa Citizen. August 6, 2008, A1.
} 
In explaining the apparent stinginess of the JSS funding in 2010 the Harper government had encountered a much more different fiscal climate: a global recession in 2008-2009 led to large-scale fiscal stimulus programs. This in turn, saw the Harper government approve the beginning of defence spending cuts and procurement deferrals in the 2010 budget, on through to 2014-15. ${ }^{48}$ In short, by the time the JSS came up again for cabinet approval it was now one of six naval and coast guard maritime procurement projects competing for scarce dollars. ${ }^{49}$

With the JSS now under the responsibility of the bureaucratic-led NSS, the last political executive decisions undertaken by the Harper government occurred in October 2013. On October $25^{\text {th }}$, in what can be inferred as a way to give the appearance that progress was being made on the JSS project, then defence minister Rob Nicholson announced that the JSS would be known as the Queenston-class with the two budgeted JSSs being named HMCS Queenston and HMCS Châteauguay, after War of 1812 battles. ${ }^{50}$ The names were not a coincidence but a reflection of the Conservative's War of 1812 public relations' work in emphasizing the War in public memory and distinguishing themselves from the Liberals on an aspect of Canadian identity. ${ }^{51}$ In 2016 it emerged that the RCN had selected the name for a third JSS in the event that money is ever

\footnotetext{
${ }^{48}$ Canada. Office of the Parliamentary Budget Officer. Fiscal Sustainability of Canada's National Defence Program. Ottawa: 2015, 1, 6.

${ }^{49}$ Canada. Public Services and Procurement Canada. "About the National Shipbuilding Strategy". Accessed July 17, 2017: http://www.tpsgc-pwgsc.gc.ca/app-acq/amd-dp/mer-sea/sncn-nss/apropos-about-eng.html

${ }^{50}$ Canada. Department of National Defence. DND Press Release. "Minister Nicholson announces names for the Royal Canadian Navy's new Joint Support Ships," October 25, 2013. Accessed January 5, 2017:

http://www.forces.gc.ca/en/news/article.page?doc=minister-nicholson-announces-names-for-the-royal-canadiannavy-s-new-joint-support-ships/hn74yaf6.

${ }^{51}$ For more information on the Harper government's approach to Canadian military history see: Frenette, Yves, "Conscripting Canada's Past: The Harper Government and the Politics of Memory", Canadian Journal of History 49, no. 1 (2014), 49-65; Taber, Jane. "Harper spins a new brand of patriotism." The Globe and Mail, August 19, 2011. Accessed July 11, 2017: https://beta.theglobeandmail.com/news/politics/ottawa-notebook/harper-spins-a-newbrand-of-patriotism/article618385/?ref=http://www.theglobeandmail.com\&; Geddes, John. "How Stephen Harper is rewriting history.” Maclean's, July 29, 2013. Accessed August 31, 2017: http://www.macleans.ca/news/canada/written-by-the-victors/.
} 
provided to build it: HMCS Crysler's Farm. ${ }^{52}$ (The name games continued under the Justin Trudeau Liberal government when in September 2017 the JSS was rechristened as the Protecteur-class with the original Protecteur and Preserver names re-assigned to the two new ships).$^{53}$ Finally, in October 2013, public works minister Diane Finley and industry minister James Moore announced $\$ 3.3$ billion in new contracts for Seaspan to build 10 "additional large non-combat" Canadian Coast Guard ships. As of 2018, it is not clear if these new construction projects will negatively impact the JSS build schedule, particularly considering the problems Seaspan has encountered in its preparations for the JSS construction. ${ }^{54}$

\section{Exogenous Explanations}

\section{a. Defence Procurement Bureaucracy}

$\underline{D N D / C A F}$ : A key factor cited as contributing to delaying the JSS was the original 2004-2008

JSS statement of requirements, chiefly that they were unrealistic and consequently unaffordable.

This situation was compounded by DND and the CAF's lack of expertise on shipbuilding

following defence cutbacks and the completion of the Halifax-class frigates in the 1990s. ${ }^{55}$ As

the organization responsible for identifying military capabilities, DND in conjunction with the

\footnotetext{
52 Pugliese, David. "Royal Canadian Navy picks a name for a third Joint Support Ship." Ottawa Citizen, April 8, 2016). Accessed 5 January 2017: http://ottawacitizen.com/news/national/defence-watch/royal-canadian-navy-picksa-name-for-a-third-joint-support-ship.

${ }^{53}$ Canada. Department of National Defence. News Release. "Joint Support Ships to be renamed Protecteur and Preserver," September 12, 2017: https://www.canada.ca/en/department-nationaldefence/news/2017/09/joint_support_shipstoberenamedprotecteurandpreserver.html

${ }^{54}$ Canada. Public Services and Procurement Canada. Government of Canada News Release. "Vancouver Shipyards to build Medium Endurance Multi-Tasked Vessels and Offshore Patrol Vessels for the Canadian Coast Guard," October 7, 2013: http://news.gc.ca/web/article-en.do?nid=778419; Byers, Michael and Stewart Webb. Rideau Institute/Canadian Centre for Policy Alternatives. "Blank Cheque: National Shipbuilding Procurement Strategy Puts Canadians At Risk." Ottawa: 2013, 11.

${ }^{55}$ Canada. Department of National Defence. Chief Review Services: Internal Audit of the Joint Support Ship (JSS) Project. Ottawa: November 2011.; Sloan, Something Has To Give, 29; Canada. Department of National Defence. Defence Performance Report 2008-2009. Ottawa: 2008, 55.
} 
CAF, had the onus for stipulating the requirements it wanted in the JSS. In seeking a replacement for three AORs, the DND and the CAF, particularly Maritime Command, sought a new class of ship that could go beyond simply replenishing the fleet at sea. The fact that major platform procurements in Canada are often generational and involve purchases in limited numbers merely encouraged DND and the navy to integrate as many capabilities as possible into the ship design. ${ }^{56}$

In the early 1990s, before the term 'Joint Support Ship' was introduced, naval planners referred to the AOR replacement project as the 'Afloat Logistics Sealift Capability' (ALSC). The requirements drawn up for the ALSC reflected the experiences the navy and its allies had encountered in the post-Cold War era. Operations during the 1991 Gulf War, disaster relief missions in Florida and the Caribbean in the early 1990s, and the provision of a joint support headquarters to Australian-led UN operations in East Timor in 1999 all demonstrated the importance of having ships that could perform in littoral waters (i.e. close to shore) and not simply on the high seas of the north Atlantic. One significant stand-out mission from this time period was the 1992-1993 deployment of the HMCS Preserver to Somalia, in which that AOR served, albeit in a limited capacity, as a support ship for Land Force Command units deployed in-country. The sum total of theses maritime operational experiences from the 1990s was the need for Maritime Command to have ships designed to operate in locations where port infrastructure was either non-existent or in hostile territory. ${ }^{57}$

\footnotetext{
${ }^{56}$ Rob Huebert. The Royal Canadian Navy: Facing Rough Seas (Calgary: Canadian Global Affairs Institute, 2016), 3.

${ }^{57}$ Canada. Department of National Defence. Operational Research Division. Afloat Logistics and Sealift Capability: Simulation-based Fleet Sizing Vol. 1. Ottawa: 2001), 1; Thomas, Doug. "Afloat Logistics Support of Joint Support Ship?" Canadian Naval Review 9, no. 2 (2013): 41.
} 
Such ships would also need to be capable of sealift (i.e. ferrying the army's troops and equipment) and of assisting ground forces ashore through the provision of helicopter and landing ship support and harbouring supplies. ${ }^{58}$ For the DND, this latter ALSC requirement became especially poignant in August 2000 when a contract dispute with the owners of a container ship, the GTS Katie, saw a large shipment of Land Force Command's armoured vehicles stuck at sea. Returning home from army operations in Kosovo, the Katie had to be boarded by armed CAF personnel after it refused to travel to Montreal. The ship had been carrying 200 armoured vehicles ( 20 percent of the army's fleet), plus five tanks and nearly 400 crates containing rifles, ammunition and communications equipment. The Katie incident illustrated the risk of relying on rented transport ships for sealift capability. ${ }^{59}$ Faced with the challenges of depending on two aging, inadequate AORs (after 1998), unreliable contracted ships or costly air transport that, when relying upon Ukrainian rentals, took a tool on the air force's decrepit C-130 Hercules fleet, the DND/CAF identified the ALSC as one of its key needed procurements in their own internal policy document, Defence Planning Guidance $2000 .{ }^{60}$ Lacking political executive endorsement, the Guidance sought a planned project start for the ALSC in 2001-2002 with a new ship delivered by $2007-2008 .{ }^{61}$

\footnotetext{
${ }^{58}$ Huebert, The Royal Canadian Navy: Facing Rough Seas, 3.

${ }^{59}$ Canada. Department of National Defence. Leadmark: The Navy's Strategy for 2020 (Ottawa: Directorate of Maritime Strategy, 2001), 64-65; Cooper, Barry. "Getting there from here." National Post, August 8, 2005, A16; "Canadian navy boards ship carrying military supplies." The Independent, August 3, 2000. Accessed 2 September 2016: http://www.independent.co.uk/news/world/americas/canadian-navy-boards-ship-carrying-military-supplies711281.html.

${ }^{60}$ Confidential source, telephone interview with the Author, January 22, 2017; Confidential source, telephone interview with the Author, January 5, 2017.

${ }^{61}$ Bercuson, David J., Aaron P. Plamondon, and Ray Szeto. An Opaque Window: An Overview of Some Commitments Made by the Government of Canada Regarding the Department of National Defence and the Canadian Forces: 1 January 2000 - 31 December 2004 (Calgary: Canadian Defence and Foreign Affairs Institute, 2006), 30 .
} 
With these experiences in mind, DND and CAF officials proposed an ambitious set of requirements for the ALSCs. Aiming for three to four ships, both department and military brass envisioned the ALSC as an entirely new class of vessel: no longer confined to just replenishing fuel and food stocks of other ships in the fleet, each ALSC would be capable of carrying " 8,000 to 10,000 tonnes of fuel, 500 tonnes of JP 5 aviation fuel, 300 tonnes of ammunition and 230 tonnes of potable water". The ASLC would also have 2,500 meters of deck space for vehicles and containers, and capability to carry four large maritime helicopters with an elevator to transfer them between the deck and hangar space. Each ASLC would be equipped with a joint force headquarters. ${ }^{62}$ The ALSC would be a hybrid between an AOR and an amphibious assault ship design, but it would also be a class of vessel that did not yet exist in any navy. Externally, public support for the project came from former senior CAF officers on acquiring a ALSC-like ambitious sealift capability. ${ }^{63}$ Internally, a "forceful personality" in the form of Vice Chief of Defence Staff, Vice Admiral Ron Buck, pushed for a ship with both replenishment and "destroyer-like capabilities such as command and control, and a field hospital". ${ }^{64}$

DND/CAF officials convinced senior government officials in the Martin administration that the $\$ 2.9$ billion was sufficient to buy three Joint Support Ships but the budget likely contributed to a paring down of the early ALSC requirements by the time the project went before cabinet in April 2004. In the 2004-2008 iteration of the JSS, the DND/CAF were pushing for the purchase of three 28,000 tonne ships, with 1,500 metres of deck space (down from 2,500 under the ALSC), and capable of sealift and transporting the equivalent of an army battle group of several hundred troops and equipment. The JSS were also expected to be equipped with

\footnotetext{
${ }^{62}$ Hobson, Sharon. "Plain Talk: JSS Adrift in a Strategic Black Hole." Canadian Naval Review 6, no. 3 (2010): 35.

${ }^{63}$ Wattie, Chris. "By land, by sea: 'Sea Horse' would make Canada's military able to intervene just about anywhere in the world." The Ottawa Citizen, October 9, 2004, B1.

${ }^{64}$ Confidential source, Telephone interview with the Author, January 5, 2017.
} 
strengthened hulls, permitting the ships to sail in Arctic ice measuring up to 0.7 metres think. ${ }^{65}$ These vessels would be the largest ships in naval service since the retirement of Canada's last aircraft carrier, the HMCS Bonaventure, in $1970 .^{66}$

Initially, there was a delay in getting the JSS to the Paul Martin cabinet table because of tensions between the three armed services within the CAF. One source of this pressure was funding. Before the Martin government approved of the JSS in 2004, an undisclosed period of time was spent by the DND and the CAF in trying to get agreement on "whether to favour the CF-18 replacement or a new AOR" for prioritizing for funding. ${ }^{67}$ The navy won out, likely on the grounds that its air force counterparts had already obtained a $\$ 2.6$ billion modernization program for its CF-18s. Launched in 2001, that modernization project tentatively pushed-off a jet fighter replacement to at least 2017. With only two AORs remaining and having entering their fourth decade of service there was little flexibility left to avoid an AOR replacement project. Of note, given the belt tightening of the 1990s, DND had to rely upon existing defence dollars to undertake the CF-18 modernization, a budget cap that it saw it only capable of upgrading 80 of its 139 jets. ${ }^{68}$ Air Command would have to wait until the 2008 Canada First Defence Strategy to see money committed to a CF-18 replacement, a saga that is still playing itself out as of writing. ${ }^{69}$

\footnotetext{
${ }^{65}$ Shadwick, "The Joint Support Ship Revisited", 63.

${ }^{66}$ Wattie, Chris. "The big boat is coming back: Military to buy largest ship since this beast was scrapped." National Post, April 19, 2004, A1.; Jacobsen, Henning. "The RCN's Joint Support Ship disaster." Vanguard, August 12, 2015. Accessed 17 May 2016: http://www.vanguardcanada.com/2015/08/12/the-joint-support-ship-debacle/.

${ }^{67}$ Confidential source, Telephone interview with the Author, January 14, 2017.

${ }^{68} \mathrm{http}: / /$ www.oag-bvg.gc.ca/internet/English/parl_oag_200411_03_e_14907.html\#ch3hd3a

${ }^{69}$ Canada First Defence Strategy, 4; For a succinct overview of the attempted F-35 procurement see Richard Shimooka. The Fourth Dimension: The F-35 Program, Defence Procurement, and the Conservative Government, 2006-2015 (Ottawa: Conference of Defence Associations Institute, 2016);
} 
Another area of armed services tension was determining what the term 'jointness' actually meant for each of the armed services. As a class of ships meant to carry Air Command helicopters, transport soldiers, and refuel Maritime Command ships, "not every [armed] service had the same idea" on what a 'joint' support ship requirement entailed and to whose benefit the requirement met. Consequently, "compromises on project priorities between [the] armed services" occurred to get the JSS into DND's Investment Plan, especially once it was agreed that the navy and army would not have to contribute money or personnel to the project. ${ }^{70}$ There seemed to be little indication of JSS delays brought about by inter-service tensions once the project was approved at the cabinet level, in 2004. If anything, especially following the cancellation of the first RFP in 2008, Maritime Command relied on its peers in the army to support the project. ${ }^{71}$ With the JSS, the army saw a project that addressed a need that had been missing in the CAF since the decommissioning of the last aircraft carrier in 1970: the ability to move large numbers of soldiers and army equipment by sea. Prominent army officers, like Commander of Land Force Command, Lieutenant-General Andrew Leslie, and the CDS, General Rick Hillier, spoke out in favour of the JSS. Leslie went so far as to state publicly in front of the House of Commons Standing Committee on National Defence in 2007 that the JSS acquisition was not disadvantaging any of the army's other major projects. ${ }^{72}$ Hillier, a career army officer and author of the Martin government's Defence Policy Statement which set out the strategic vision for the JSS in the CAF, had been motivated to support the JSS based on his experiences of

\footnotetext{
${ }^{70}$ Confidential source, Telephone interview with the Author, January 18, 2017.

71 Ibid.

${ }^{72}$ Lieutenant General Andrew Leslie, Chief of Land Staff and Commander of the Army, testimony before the Standing House Committee on National Defence, February 22, 2007.
} 
seeing the army unable to deploy quickly during the Gulf War and the NATO Kosovo mission in $1999 .^{73}$

It is worth stressing that in pushing for the type of requirements sought in the 2004-2008 iteration of the JSS, Maritime Command was trying to achieve, in one ship, what is commonly found in two separate classes of ships. Among Canada's allies, the ability to refuel and supply naval forces at sea is separate from the ability to transport troops and provide substantial support to ground forces ashore. For example, the Royal Netherlands Navy relies upon one supply ship, or AOR, to replenish its six frigates and four patrol ships, in addition to two amphibious ships, or Landing Platform Docks (LPDs), to transport troops and equipment for operations ashore. ${ }^{74}$ New Zealand likewise has a scaled down version of the same fleet configuration with two frigates, one AOR (a commercial off-the-shelf design), and one amphibious ship. ${ }^{75}$

However, what crippled the ambitious requirements sought for the JSS was the DND/CAF's lack of expertise in shipbuilding. By the time the JSS was officially endorsed at the political executive level in 2004, close to a decade had passed since the CAF had last acquired a large, indigenously-designed naval ship. Cutbacks in the 1990s under the Chrétien government saw much of defence bureaucracy's institutional knowledge on complex shipbuilding retired or laid off. ${ }^{76}$ The human resource constraint was especially noticeable with the JSS Project Management Office housed in DND. The office was "decidedly smaller" than the Halifax-class

\footnotetext{
${ }^{73}$ Confidential Source, Email interview with the Author, November 30, 2016; Wattie, Chris. "General wants big new warship: Canada's new chief of defence staff has ambitious plan to overhaul all three services of Canadian Forces." Edmonton Journal, February 14, 2005, A5.

${ }^{74}$ Royal Netherlands Navy. "Ships." Accessed 16 December 2016: https://www.defensie.nl/english/organisation/navy/contents/navy-units/ships

${ }^{75}$ Royal New Zealand Navy. "Meet the Feet" (2016). Accessed 16 December 2016: http://navy.mil.nz/mtf/default.htm.

${ }^{76}$ Perry, Putting the 'Armed' Back Into the Canadian Armed Forces: Improving Defence Procurement in Canada, 6-9.
} 
build in the late-1980s and 1990s, and was more dependent on contracted engineering support for designing than for past procurement projects. ${ }^{77}$ The 2008-2009 review conducted after the failure of the first RFP noted that the lack of institutional knowledge within DND played an important role in underestimating the cost and complexity of bringing the JSS to fruition.

The effect of this knowledge gap led DND and the CAF to compose their JSS requirements in a vacuum, not accounting for the state of the domestic shipbuilding market and the complexity involved in creating an entire new class of ship. As one insider noted, both industry and the navy "had not talked enough leading up to JSS." ${ }^{78}$ Accordingly, it was only in February 2005 - almost a year after the project received cabinet approval - that DND sent out Letters of Interest to gauge the shipbuilding industry's interest in the project. The remainder of that year featured back and forth discussions between the department and interested shipyards on what a JSS design would look like based on the requirements written up by the CAF and DND. That fall, a RFP for project definition contracts was issued. ${ }^{79}$ After the project definition contracts were awarded by the PWGSC minister in December 2006 it became increasingly clear to the shipbuilding industry that the $\$ 2.9$ billion budget established under the Martin government and maintained by their Conservative successors, was insufficient. In short, the navy "over spec'ed" the JSS statement of requirements (a "franken spec" in defence industry parlance), producing "requirements so robust it [the JSS] couldn't meet the budget". The absence of an established relationship and open communications channels between the defence bureaucracy and industry meant that when TKMS and SNC-Lavalin submitted their final bids on the JSS in

\footnotetext{
${ }^{77}$ Vice-Admiral Drew Robertson, then-Chief of Maritime Staff and Command of the Navy, testimony before the Standing House Committee on National Defence, February 22, 2007.

${ }^{78}$ Confidential Source, Telephone interview with the Author, January 27, 2017.

${ }^{79}$ Bercuson et al., An Opaque Window, 31.
} 
March 2008, DND "thought industry was lying to them"; the firms had indicated to the department that the requirements exceeded the budget. ${ }^{80}$

The failure of the DND/CAF to have properly costed their requirements or account for the state of Canada's domestic shipbuilding capacity led to the cancellation of the first RFP in August 2008, which added a two-year delay to the project as the Harper government sought a reorganization of all federal shipbuilding plans under the NSPS. By DND's own admission, the proposals submitted by both industry consortia were "not compliant with the basic terms of the Request for Proposals". In effect, they were "significantly over the established budget provisions" ${ }^{81}$ The department's handling of the JSS file in 2004-2008 did not enamour it to its political executive bosses or fellow bureaucratic counterparts in PWGSC, IC and the central agencies: the impression was that "clearly, we're not competent" as one official worded it. ${ }^{82}$ DND was also having to contend with a widespread perception within these same organizations that the department had bypassed the procurement process too many times with its invocation of Urgent Operational Requirements for sole source purchases related to the Afghanistan war (e.g. Leopard II tanks) ${ }^{83}$ In short, permanent, quick sole-source buys for the JSS were now untenable in the political and bureaucratic climate of 2008-2010 Ottawa. Even though senior DND officials, including the ADM (Mat), were aware of the risks inherent in an indigenous designed and built JSS they believed the risks could be ameliorated by having the one prime contractor responsible for building the ship and providing a long-term maintenance contract. ${ }^{84}$ That DND's

\footnotetext{
${ }^{80}$ Confidential Source, In-person interview with the Author, January 23, 2017.

${ }^{81}$ Canada. Department of National Defence. Major Crown Projects: Joint Support Ship (JSS) 2009-2010. Ottawa: 2009.

${ }^{82}$ Confidential Source, Telephone interview with the Author, January 27, 2017.

${ }^{83}$ Confidential Source, In-person interview with the Author, January 27, 2017.

${ }^{84}$ Dan Ross, then-Assistant Deputy Minister (Materiel), testimony before the Standing Committee on National Defence, February 8, 2007.
} 
project estimates were inaccurate compounded this perception. Tom Ring wrote in 2016 that DND underappreciated the cost of building the JSS domestically, where there was "an additional 25 per cent risk premium". Once the process was cancelled in August 2008 some $\$ 50$ million of the project's $\$ 2.1$ billion had been spent with "nothing to show for it". ${ }^{85}$ The end result of the failed JSS RFP in 2008 was the dilution of DND and the CAF's role in maritime procurement decision-making. Under the NSPS framework approved in June 2010, DND/CAF retained the JSS project management office to undertake options analysis and project definition work, but major decision procurement decisions rested with the PWGSC-led NSPS Secretariat, of which DND was a key player but not the player. ${ }^{86}$ This is not to say that the defence bureaucracy opposed the NSPS approach. In fact, following the failed RFP in August 2008, DND partnered with PWGSC and IC officials to review the Canadian shipbuilding sector and the reasons for the failure over the time period of 2008-2009. Of course, in not getting any new substantial increases in the JSS's budget, DND turned towards re-examining the ships' capabilities. ${ }^{87}$ Less than a year after the cancellation of the first RFP, in May 2009 senior DND officials admitted that fiscal constraints were leading to uncertainty on whether three ships could be procured in the end. The conclusion by 2009 was that only an off-the-shelf design could ensure that the navy got at least two ships within the budget the Harper Conservatives had imposed ${ }^{88}$ So pressing was the need to acquire a replenishment capability that following the failure of the RFP, DND and CAF had even (briefly) returned to the possibility of buying two fuel tankers and a transport ship instead

\footnotetext{
${ }^{85}$ Ring, Tom. “The National Shipbuilding Procurement Strategy: How did we get to where we are now?" Policy Update (Calgary: Canadian Global Affairs Institute, 2016), 1-2.

${ }^{86} \mathrm{http}: / /$ www.lop.parl.gc.ca/content/lop/ResearchPublications/2015-35-e.html\#a13

${ }^{87}$ Robert Fonberg, then-Deputy Minister of National Defence, testimony before the Standing Senate Committee on National Security and Defence, May 25, 2009.

${ }^{88}$ Dan Ross, then-Assistant Deputy Minister (Materiel), testimony before the Standing Senate Committee on National Security and Defence, May 25, 2009; Canada. Office of the Parliamentary Budget Officer. Feasibility of Budget for Acquisition of Two Joint Support Ships (Ottawa: 2013), 1-7.
} 
of pursuing a domestic built JSS. ${ }^{89}$ In the end, DND and the senior Maritime Command leadership endorsed the review's recommendation to overhaul all federal shipbuilding with the creation of the NSPS. The main appeal of the NSPS for the navy was that it assured three decades of continuous naval ship construction and not the piecemeal approach that had long characterized Canadian naval procurement. ${ }^{90}$

In comparison to the 2004-2008 period, Joint Support Ship delays owing to the actions of DND and the CAF are more circumstantial in the second iteration of the project. The nature of the NSPS structure meant that the JSS Project Management Office could only consider "existing proven" off-the-shelf designs from NATO members or a domestic design that was of the same price. Further, a fixed budget necessitated two ships, and with a pre-determined builder, Seaspan. ${ }^{91}$ A new statement of requirements was drawn up reflecting these parameters. Gone were the ambitious hybrid requirements that had plagued the 2004-2008 project. The JSS's capabilities were reduced to having a standard AOR at-sea support for naval task forces, plus limited sealift operations, and limited support to ground forces deployed ashore. Lane space for vehicles was cut, as was the joint task force headquarters; these had been key components of the expeditionary-focused roles of the Martin-era statement of requirements. The number of personnel to be accommodated onboard dropped from 320 to 250 , effectively removing any significant army troop carrying ability. ${ }^{92}$ The absence of backlash from the army over the loss of hundreds of metres of lane space for its equipment was likely offset by Air Command's

\footnotetext{
${ }^{89}$ Pugliese, David. "Navy looks into buying fuel tankers." The Telegram, August 28, 2008, A6.

${ }^{90}$ Confidential Source, Telephone interview with the Author, January 27, 2017; Ring, "The National Shipbuilding Procurement Strategy: How did we get to where we are now?", 1-2.

${ }^{91}$ Confidential Source, Telephone interview with the Author, January 14, 2017.

${ }^{92}$ Canada. Department of National Defence. Report on Plans and Priorities 2011-2012; Canada. Department of National Defence. Report on Plans and Priorities 2012-2013; Hobson, "Plain Talk: JSS Adrift in a Strategic Black Hole", 36.
} 
acquisition of new strategic- and tactical aircraft fleets which had entered service by 2010, thus negating the impetus to require an amphibious-like transport capability. ${ }^{93}$

With the new requirements in place, DND estimated in 2010 that 25 months was necessary to complete the project definition stage, whereby a design would be picked and Seaspan would have prepared its yard for building the ships. In 2011 the DND/CAF thought that the project definition could be completed by February 2013, with a contract award for construction issued in March. At this rate, the first JSS could be delivered in "Spring 2017". 94

Yet as of 2017 the JSS's project definition stage remains unresolved. Opting for a proven off-the-shelf design led to a series of ostensibly unforeseen problems. For one, there were few existing proven designs to choose from given the requirements put in place. After the review into the JSS failure in 2009 was complete and the new requirements were settled DND awarded contracts to two foreign designs: TKMS's Berlin-class AOR design, in use by the German Navy (Deutsche Marine) since 2001, and the newer Navantia Cantabria-class AOR, in use by the Spanish Navy (Armada Española) since 2010. A third contract was issued to Ottawa-based BMT Technologies to develop a new, domestic design. ${ }^{95}$ Difficulties arose when it came to negotiating with each of the European firms to acquire the intellectual property rights to their respective designs in order to 'Canadianize' them for Maritime Command service. In particular, design modifications were considered necessary in order to ensure that the navy had the capability to operate in both the North Atlantic and Pacific Oceans. For example, the Berlin-class was designed primarily for German operations in the Baltic Sea where distances to ports were shorter

\footnotetext{
${ }^{93}$ Confidential Source, Email interview with the Author, November 30, 2016.

94 Canada. Department of National Defence. Major Crown Projects: Joint Support Ship (JSS) 2011-2012.

${ }^{95}$ Dan Ross, then-Assistant Deputy Minister Materiel, testimony before the Standing House Committee on National Defence, April 1, 2010; CTV News. "Navy considers modified designs for new supply ship." Accessed May 11, 2017: http://www.ctvnews.ca/navy-considers-modified-designs-for-new-supply-ship-1.617026.
} 
and the climate more temperate. ${ }^{96}$ Navantia soon bowed out of the competition over frustrations with these negotiations and later moved on to shipbuilding opportunities with the Royal Australian Navy. But by the time the Berlin design was officially announced for the JSS in May 2013, DND's negotiations with TKMS had added one-and-a-half years to the project. ${ }^{97}$

PWGSC: Under the first iteration of the JSS, PWGSC adhered to its traditional role of protecting the integrity of the contracting process. The department became involved in the JSS when it oversaw the awarding of two project definition design contracts in December 2006 from among the four bidders, Irving Shipbuilding, BAE Systems, TKMS, and SNC-Lavalin Profac. ${ }^{98}$ SNCLavalin and TKMS won the design contracts. Given the nature of the contract (picking two companies to design a ship based on the DND/CAF's requirements) this was an surprisingly uncontroversial move with no known discernable impact on the planned JSS project schedule. This is in complete contrast to the next phase of the process involving the selection of one of the two designs to initiate project implementation in August 2008.

In March 2008, TKMS and SNC-Lavalin tendered their bids to PWGSC for the JSS. ${ }^{99}$ However, in submitting their bids the companies indicated to PWGSC and DND officials that the project's $\$ 2.1$ billion budget was insufficient to meet the requirements laid out by National Defence and the military. ${ }^{100}$ One company indicated that its design could only deliver two ships based on the project budget while another stated that it could produce three ships but only if the

\footnotetext{
${ }^{96}$ Confidential Source, Telephone interview with the Author, January 14, 2017; Confidential Source, Telephone interview with the Author, September 27, 2016.

${ }^{97}$ Senior Government Official \#3 (ret'd), Interview with the Author, September 25, 2016.

${ }^{98}$ Jacobsen, “The RCN's Joint Support Ship disaster."

${ }^{99}$ Canada. Department of National Defence. Chief Review Services: Internal Audit of the Joint Support Ship (JSS)

Project. Ottawa: November 2011. Accessed 3 January 2017: http://www.crs.forces.gc.ca/reportsrapports/2011/176P0934-eng.aspx.

${ }^{100}$ Confidential source, In-person interview with the Author, January 17, 2017; Confidential source, Telephone interview with the Author, January 14, 2017.
} 
requirements were de-scoped. Even though PWGSC knew that allowing the RFP process to continue would result in a failed process and a project restart, senior PWGSC officials refused to alter the RFP, despite behind the scene protestations from their colleagues in DND. PWGSC made it clear that any deviation from the RFP process, including returning to the Treasury Board cabinet committee for more money or descoping the requirements, would open the federal government up to possible litigation on the grounds of collusion from those companies that had failed in not getting a definition design contract in $2006 .{ }^{101}$ The process therefore continued until it failed, necessitating a restart two years later in $2010 .{ }^{102}$ Notably, PWGSC's adherence to the contract process did not preclude litigation. TKMS filed a claim against the federal government in 2010 for costs incurred due to the failed RFP in 2008. Negotiations resulted in a $\$ 8$ million settlement - money that came out of the JSS budget. ${ }^{103}$

As noted earlier, PWGSC had been part of the JSS review undertaken by DND and IC in 2008-2009 that recommended the NSPS model. Reflecting the Harper government's loss of confidence in DND under the NSPS, PWGSC became the lead department on maritime procurement. ${ }^{104}$ The NSPS Secretariat and its ADM and DM level governance structure became involved in shaping the restarted JSS at several points over the period of 2010-2015. The first was on October 19, 2011 when the Secretariat selected Seaspan's Vancouver Shipyards Co. Ltd to build the federal government's $\$ 8$ billion non-combat package of ships. This included the JSS alongside three CCG shipbuilding projects: one Polar Icebreaker, three Offshore Fisheries

\footnotetext{
${ }^{101}$ Confidential source, Telephone interview with the Author, January 14, 2017..

102 Subject Matter Expert \#1, interview with the Author, October 5, 2016.

103 Pugliese, David. "Government Compensated ThyssenKrupp Marine Systems For Failed Joint Support Ship Project." Ottawa Citizen, January 21, 2014.

${ }^{104}$ Canada. Office of the Auditor General of Canada. National Shipbuilding Procurement Strategy (Ottawa: YEAR), 12.
} 
Science Vessels, and one Offshore Oceanographic Science Vessel. ${ }^{105}$ While not the direct fault of the Secretariat - there were, after all, only two shipyards bidding on the non-combatant NSPS package - the selection of Seaspan would lead to problems in progressing through the restarted JSS process (detailed in the next section). ${ }^{106}$ An umbrella agreement between PWGSC and Seaspan, signed in February 2012, established the yard as the prime contractor for building the non-combat package. The challenge here was that the Secretariat had not selected the construction for the sequencing of ships. Both the CCG's Polar Icebreaker and the RCN's JSSs were slated for construction at the same time in the Vancouver shipyard. ${ }^{107}$ Officially, PWGSC stated that this "fact was known and accepted" by DND and CCG officials when the yard was selected. However, behind the scenes there was confusion. Reflecting a clear communications failure between the departments, senior RCN officials were under the impression that once an agreement on a yard and design was made, the ships would be acquired in 3-4 years. They had not considered the other ships Seaspan had to build. ${ }^{108}$ It would take until October 11, 2013 to clarify this concern. ${ }^{109}$ After taking into consideration each services' capability gaps and possible refits and life extensions the decision was made by the NSPS Secretariat to place the JSS third in line for building at the Seaspan yard, ahead of the Polar Icebreaker. ${ }^{110}$ It is estimated that

\footnotetext{
${ }^{105} \mathrm{http}: / /$ news.gc.ca/web/article-en.do?mthd=tp\&crtr.page=1\&nid=656979\&crtr.tp1D=1; Canada. Public Services and Procurement Canada. Shipbuilding projects to equip the Royal Canadian Navy and the Canadian Coast Guard -National Shipbuilding Strategy: February 2012 to December 2015 status report. Accessible at: http://www.tpsgc-pwgsc.gc.ca/app-acq/amd-dp/mer-sea/sncn-nss/rapport-report-20151231-3-eng.html\#a4; Canada. Public Services and Procurement Canada. National Shipbuilding Strategy: February 2012-December 2015 Status Report. Ottawa: December 2015).

${ }^{106}$ The Secretariat used a 100 point score sheet for evaluating the shipyards' bids. Sixty points were allocated for each respective yard's infrastructure and building capacity. Seaspan's bid for the non-combatant package scored 76.8 points - slightly better than the other non-combatant bidder, the bankrupt Davie Shipyard in Quebec, who scored 63.2 points. See: Byers, Michael and Stewart Webb. Rideau Institute/Canadian Centre for Policy Alternatives. "Blank Cheque: National Shipbuilding Procurement Strategy Puts Canadians At Risk." Ottawa: 2013 10.

${ }^{107}$ Canada. Department of National Defence. Report on Plans and Priorities 2013-2014.

${ }^{108}$ Confidential source, Telephone interview with the Author, January 27, 2017.

${ }^{109}$ Canada. Department of National Defence. Report on Plans and Priorities 2014-2015.

${ }^{110}$ Perry, 2015 Status Report on Major Defence Equipment Procurements, 41
} 
determining the build sequencing at Seaspan delayed the JSS project by another 6 to 7 months. ${ }^{111}$ On the same day that the NSPS Secretariat publicly clarified the sequencing problems it also admitted that JSS construction was now pushed back to $2016 .{ }^{112}$ But by placing the JSS ahead of the Polar Icebreaker the CCG had to keep its largest and oldest icebreaker, the CCGS Louis St.Laurent, in service until its replacement was built; a decision that has seen the St-Laurent, originally planned for decommissioning in 2000, to undergo a \$55 million refit in 2014 to maintain operational capability until the 2020s. ${ }^{113}$

IC: As the JSS predates the 2014 Defence Production Strategy, the IC, when compared to its sister departments in DND and PWGSC, remained a marginal player in the project. IC's role was largely confined to ensuring that the longstanding Industrial Regional Benefits (IRB) policy resulted in the JSS contractors spending 100 percent of the contract's value, whether in new monies or through in-kind contributions. Under the NSPS model introduced in 2010, the department's role was increased with the incorporation of the 'Value Proposition', which required each of the two successful NSPS yards, Seaspan and Irving, to invest 0.5 percent of the total value of the NSPS contracts in three areas: human resources development, technology investment, and industrial development. ${ }^{114}$ However, the Value Proposition requirement did not make IC a decisive decision-maker in the JSS procurement process. Unlike the contentious disputes around regional benefits seen in the FWSAR and MSVS-SMP projects, the Harper government had already determined that the ships would be built in Canada with domestic prime contractors. So, for an IC perspective, its primary role was relegated to ensuring that Seaspan

\footnotetext{
111 Senior Government Official \#3 (ret'd), Interview with the Author, September 25, 2016.

$112 \mathrm{http}: / /$ news.gc.ca/web/article-en.do?mthd=tp\&crtr.page=1\&nid=780089\&crtr.tp1D=1 (Accessed May 14, 2017).

113 Byers, Michael. "Why Canada's search for an icebreaker is an Arctic embarrassment." Globe and Mail, January 21, 2014.

${ }^{114}$ Canada. Innovation, Science and Economic Development Canada. National Shipbuilding Strategy, November 3 , 2016. Accessed 5 February 2017: https://www.ic.gc.ca/eic/site/sim-cnmi.nsf/eng/uv00050.html.
} 
met its regional industrial benefits as per the 2012 umbrella agreement signed with the NSPS Secretariat. ${ }^{115}$

\section{b. Industry}

When it came to the first iteration of the JSS, the state of the country's shipbuilding industry played an indirect role in contributing to delaying the project, chiefly in impacting the cost estimate of manufacturing the ships domestically. DND's own internal assessment of the failed 2008 RFP partly attributed blame to the dilapidated state of Canada's shipyards which were found to have comparably lower productivity levels and were in need of expensive infrastructure upgrades, in order to meet the design and build challenges expected for a complex SOR like that of the JSS project. That being said, Canada's shipyards were not entirely at fault for the expensive premium deemed necessary to build the JSS, as "an unprecedented global material and marine labour cost escalation" of 200 to 300 percent (especially in steel) occurred between 2004, (when the Martin government approved the project) and 2008(when TKMS and SNC-Lavalin submitted their bids). ${ }^{116}$

Unlike the 2004-2008 period, however, since the JSS was restarted in 2010, delays can be directly attributed to problems with the prime contractor, Seaspan. Once the Harper government made the decision to implement a 30-year rationalized shipbuilding program for all federal ships over 1000 tonnes, one of the major obstacles became the Vancouver shipyard itself. As one senior government official note, "once you shut down an industry that is that complex it is a huge

\footnotetext{
115 Seaspan Shipyards, Value Proposition (2017). Accessed 5 February 2017: http://www.seaspan.com/valueproposition-vp.

${ }^{116}$ Cited in: Canada. Department of National Defence. Chief Review Services: Internal Audit of the Joint Support Ship (JSS) Project. Ottawa: November 2011; Sloan, Something Has To Give, 2014, 29; Canada. Department of National Defence. Defence Performance Report 2008-2009, 55.
} 
challenge to start-up". ${ }^{117}$ In the case of Seaspan, the company's Vancouver yard had never built a class of ships as large as the 20,000 tonne Queenston-class JSS; in fact, the largest ship Seaspan had ever built was a commercial car ferry, the 4300 tonne MV Island Sky. ${ }^{118}$ The only naval ships it had built were eight, 210 tonne Orca Class training ships in 2004-2010. ${ }^{119}$ Consequently, Seaspan did not have the actual physical infrastructure and human resources in place to start construction as soon as the Berlin-class design was selected in 2013. That the JSS still remained in the project definition stage in 2017 is therefore a reflection of the shipyard's slow start and inability to generate sufficient building capacity. One former senior government official put it bluntly, Seaspan "had no capability whatsoever to deliver...they were the second best of a bunch of shitty options...". ${ }^{120}$ A part of this problem had to do with generating the finances needed to undertake any capability modernization. The cornerstone of the NSPS was that each of the two winning yards would have to modernize their facilities without federal money. But unlike Irving, which received $\$ 304$ million from the Nova Scotian government (with \$260 million being forgivable), Seaspan got just \$40 million from the British Columbian government. Only in November 2014, two years after signing the umbrella agreement with the Harper government, had the company marshalled the resources for a $\$ 170$ million, two-year modernization plan for its yard, a plan that was specifically aimed at improving "engineering systems, technical programs and management". ${ }^{121}$

\footnotetext{
${ }^{117}$ Senior Government Official \#1, Interview with the Author, September 23, 2016.

${ }^{118}$ Seaspan Shipyards. Seaspan Shipyards New Builds. Accessible online at: https://www.seaspan.com/seaspanshipyards-new-builds

${ }^{119}$ Seaspan Shipyards. Seaspan Shipyards - ORCAs. Accessible online at: https://www.seaspan.com/seaspanshipyards-orcas; Canada. Department of National Defence. Patrol Craft Training vessels (Orca-class). Accessible online at: http://www.navy-marine.forces.gc.ca/en/fleet-units/minor-orca.page.

${ }^{120}$ Senior Government Official (ret'd.), Interview with the Author, September 26, 2016.

${ }^{121}$ Smith, Marie-Danielle. "Harper government funded B.C. shipyard after Coast Guard ship contract despite saying it wouldn't." National Post, May 5, 2016. Accessed May 15, 2017: http://news.nationalpost.com/news/canada/canadian-politics/harper-government-funded-b-c-shipyard-after-coastguard-ship-contract-despite-saying-it-wouldnt.
} 
This need for the company to invest in engineering, technical and management skills was the result of having to contend with the challenge of going "from a very small shipyard to a very large shipyard in a very short amount of time." 22 Seaspan had to undertake a building program for multiple classes of ships along a spectrum of sizes and capabilities, from fisheries science research vessels to the largest Canadian icebreaker built in six decades and then the JSS. For the JSS, the confluence of a lack of sufficient human resource capacity in engineering, and management with the Vancouver yard's infrastructure and project history, has been borne out in the still ongoing amount of time spent since 2013 trying to customize TKMS's Berlin-class design to the yard's size. While a proven off-the-shelf design, the Berlin-class was developed with Germany's large Hamburg shipyards in mind. Therefore, Seaspan had to hire engineering consultants to both redesign their yard and the Berlin-class's modules so that they could be accommodated in the smaller Canadian facility. Ironically, given that it lost out in the NSS to Seaspan, the Davie yard in Quebec remains the only Canadian shipyard large enough to build a vessel the size of the Berlin-class. ${ }^{123}$

\section{c. Alliances and War}

The impact of the Afghanistan war on the JSS project was not apparent in 2004-2008. However, after the failure of the RFP the restarted JSS had its budget partly capped at $\$ 2.6$ billion, as the result of operational and procurement expenditures related to the war. With the Harper government similarly trying to grasp the impact of its deficit spending in the wake of the 20082009 global recession, “everyone [in DND] was giving money back to the Vice-Chief [of

\footnotetext{
${ }^{122}$ Smith, "Harper government funded B.C. shipyard after Coast Guard ship contract despite saying it wouldn't", 2016.

${ }^{123}$ Confidential Source, Interview with the Author, January 23, 2017; McKnight, Zoe. "Navy adopts German design for ships to be built in North Vancouver." Vancouver Sun, June 3, 2013. Accessible online at: http://www.vancouversun.com/Navy+adopts+German+design+ships+built+North+Vancouver/8468320/story.html
} 
Defence Staff] to fund Afghanistan". ${ }^{124}$ The budget cap certainly limited the scope and number ships to be procured but it appears unlikely that the war directly impacted the speed upon which the JSS were to be acquired.

\section{Bringing It All Together}

Is the political executive responsible for contributing to delays on the JSS project? Yes and no. There are three areas where the political executive decisions prolonged the acquisition of the JSS: project governance, policy guidance, and budgets. All areas produced outcomes and interdepartmental dynamics common to the bureaucratic politics model. While inter-service tension between the Land Force Command, Maritime Command, and Air Command was largely placated once the JSS was approved in 2004, inter-departmental conflict existed at times throughout both iterations of the JSS. In the 2004-2008 period, DND and PWGSC each approached the JSS in the silo-like function; the lack of regular, open communication between the departments saw each view the JSS from their own parochial viewpoints. DND and the navy wanted a ship that could meet their demanding multi-faceted post-Cold War operational needs and allow for the soon-as-possible retirement of the aging Protecteur-class AORs without having to contend with a capability gap. PWGSC focused on running a fair competition that adhered to the statutes and regulations governing MCP procurements. Consequently, when PWGSC officials learned from DND and industry in March 2008 that the bids would not be compliant, PWGSC's response was to follow through with the competition for another five months until it failed. The NSPS process with its inter-departmental governance structure was supposed to

${ }^{124}$ Confidential Source, Telephone interview with the Author, January 27, 2017. 
rectify this shortcoming, however, even here delays occurred because of poor communication (e.g. the lack of clarification between the RCN and CCG over which vessel should be built first, the JSS or the Polar Icebreaker?). Without a change in the statutory mandates in procurement it would appear that papering over the existing departmental divisions in defence procurement responsibilities has its limits. As per its role in pre-2014 Defence Procurement Strategy projects, IC was not a deciding player in either iteration of the JSS.

The JSS project also illustrates how conflicting policies from the political executive can contribute to delays. In Atkinson's and Nossal's examination of the original CF-18 purchase in 1980 they concluded that a part of that project's success in overcoming bureaucratic infighting was in the political executive providing clear policy direction outlining the fleet's roles, number of units, and budget (in addition to a strong interdepartmental governance structure). In the case of the JSS project, both the Martin and Harper governments did provide policy direction through the 2004 budget, the 2005 DPS, the June 2006 Canada First defence procurement strategy announcement, and the 2010 NSPS. However, such direction was undermined by another competing policy, the 2001 A New Policy Framework for the Canadian Shipbuilding and Industrial Marine Industry. The goal of acquiring a replacement AOR capability for Maritime Command had to compete with the 2001 policy's goal of ensuring that federal ships were to be built in Canada and that shipyards would be selected competitively in the hope of stimulating economic spinoffs in the country's domestic shipbuilding sector.

The 2001 policy, endorsed by the Harper government in 2006-2007, provided the context for the NSPS shipyard selection in 2010-2011. The challenge for the JSS project was that it became subservient to the larger industrial economic goal of revitalizing Canadian shipbuilding; a goal that The onus of the NSPS was, after all, to provide "economic benefits to Canadians and 
rebuild our country's shipbuilding industry", not the effective delivery of military capabilities to the CAF; ${ }^{125}$ This is best illustrated by the fact that the navy has long stated it needed three JSSs to meet its naval task force responsibilities. ${ }^{126}$

The poor state of Canada's shipyards practically ensured that a JSS build, whether using an existing off-the-shelf design like the Berlin-class or a new indigenous design was not going to be a speedy process. Irrespective of its merits at the time (given Canada's deficits and debt expenditures), the decision by the Chrétien government to cut personnel from the defence bureaucracy in the 1990s (including those with procurement knowledge in shipbuilding) and to put a freeze on any new shipbuilding projects, created a gap in institutional knowledge on the matter of designing and building naval ships indigenously. This decision deprived not just DND and the $\mathrm{CAF}$, but the federal government as a whole from capitalizing on the experience accumulated both within government and industry from the $\$ 6.2$ billion Halifax-class frigate project which concluded in 1996. Absent new orders at the end of the Halifax-class and Kingston-class projects in the 1990s two of the country's largest shipyards laid off their work forces and in the case of Irving's Saint John Shipyard in New Brunswick, shuttered its gates permanently in 2003. The Irving decision was largely driven by the Chrétien government's offer of nearly $\$ 100$ million in economic development aid in the face of no new federal shipbuilding contracts. ${ }^{127}$ Meanwhile, the remaining Halifax-class naval shipyard, the Davie yard in Levis,

\footnotetext{
${ }^{125}$ Canada. Public Services and Procurement Canada. "National Shipbuilding Strategy: Services and Information." Accessible online: http://www.tpsgc-pwgsc.gc.ca/app-acq/amd-dp/mer-sea/sncn-nss/index-eng.html

${ }^{126}$ Canada. Department of National Defence. Leadmark 2050: Canada in a New Maritime World. Ottawa: 2016, 42.

${ }^{127}$ CBC News. "Irving family closing idled Saint John shipyard." CBC News (Online), June 27, 2003. Available online: http://www.cbc.ca/news/business/irving-family-closing-idled-saint-john-shipyard-1.396417; Cox, Kevin. "Canada's largest shipyard closes." The Globe and Mail, June 27, 2003. Accessible online: http://www.theglobeandmail.com/news/national/canadas-largest-shipyard-closes/article22617919/; Webb, Stewart. Returning To Port: A Needed Course Correction to Keep the National Shipbuilding Strategy off the Rocks. Toronto: The Mackenzie Institute, 2017, 7.
} 
Quebec went into a period of receivership and multiple owners from which it only achieved a period of stability in $2012 .{ }^{128}$ As both the failed 2008 RFP and the ongoing NSPS process demonstrate, building naval ships domestically literally requires the simultaneous rebuilding of the country's shipbuilding industry.

Of course, privileging domestic firms for supplying Canada's maritime naval and coast guard needs in the name of job creation and economic offsets, by default excluded opportunities to buy ships produced overseas, (as the UK has done with its four Tide-class AORs manufactured in South Korea) or to pursue opportunities for buying ships already produced but awaiting mothballing by foreign navies (the Dutch Karel Doorman is the best example of this case). Not only would such options have been cheaper - the four Tide-class ships cost an estimated $\$ 600$ million USD - the RCN would have received its ships faster, saving the CAF, DND and the government from engaging in costly temporary options like the $\$ 700$ million Interim AOR. True, the Tide-class have been subject to an 18 month delay, but that delay pales in comparison to the decade lost on awaiting for the arrival of two JSS at a cost of $\$ 2.6$ billion, especially as the Tide-class have already begun entering service. Tellingly, the Norwegians are following the British lead in turning to South Korea for their AOR needs. ${ }^{129}$

Money is often said to represent policy in defence, but with the JSS the role of money as approved by the political executive in government budgets and at the Treasury Board cabinet committee - in contributing to project delays is less clear. Before the project was ever approved

\footnotetext{
${ }^{128}$ CBC News. "Quebec's Davie Shipyard launches new ship Cecon Pride.” CBC News (Online), October 25, 2013. Accessible online: http://www.cbc.ca/news/business/quebec-s-davie-shipyard-launches-new-ship-cecon-pride1.2251681 .

${ }^{129}$ Chuter, Andrew. "British Navy Sees Delay In Delivery Of South Korean-Built Tanker." Defense News, August 1, 2016. Accessible online: http://www.defensenews.com/story/defense/naval/2016/08/01/british-navy-sees-delaydelivery-south-korean-built-tanker/87918638/.
} 
at the political executive level - in this case, the Martin government in 2004 - the scarcity of funds and the absence of a clear policy direction during the Chrétien government saw disputes between the armed services on what Major Crown Project needed to be replaced first: the CF-18s or the Protecteur AORs. Eventually, the combination of the CF-18 modernization project and the large cash injections into the defence budget by the Martin government in 2004-2005 helped settle the issue. However, the absence of effective communication with industry early in the JSS's option analysis stage, and the loss of institutional memory within DND and the CAF on shipbuilding, led to the development of an overly ambitious SOR (or 'franken spec' in industry parlance) that was in no way capable of being reconciled with the $\$ 2.1$ billion budget. The lack of a clear policy direction from the Martin government also contributed to the ambitious JSS requirements, which were designed before the 2005 DPS was released. To the Martin government's credit, DND and the CAF reassured them that the budget was sufficient to meet the SOR.

In contrast, the Harper government, in the midst of deficit spending of its own in 20092010 , took the lesson of the failed 2008 JSS RFP and implemented a fixed budget of $\$ 2.6$ billion for the project in 2010. While doubt from the PBO exists on whether this budget is sufficient to buy two ships, the second JSS budget does not appear to have contributed to delays per se; in fact, it likely contributed to avoiding the wish-list thinking that had undermined the 2004-2008 JSS by forcing the DND and the CAF to undertake capability-cost trade-offs, such as cutting the sealift requirements. However, the budget cap came at cost to the $\mathrm{CAF}$, as now the RCN is 
expected to receive only two JSSs despite having expressed an operational need for three ships (although the Interim AOR may ameliorate the need for a third JSS if it is purchased outright). ${ }^{130}$

Of course, the political executive does not deserve all of the blame. A key exogenous impact in delaying the JSS acquisition was the defence industry and the shipyard, Seaspan. Regarding the former, the very nature of contemporary naval shipbuilding, with global supply chains and few firms means that costs (e.g. the 200 to 300 percent increase materials and labour in the 2004-2008 JSS) are beyond the control of any one Canadian government. Off-the-shelf designs have their limits as well. A foreign, existing design may very well be proven operationally, however, it was first and foremost created to meet the requirements of its foreign owners. In the case of JSS, the TKMS Berlin AOR was meant for the German Navy's needs and built in accordance with capabilities of the Hamburg shipyards. Consequently, any foreign design requires complex and expensive customization and negotiation in order to be adapted to Canada's needs, something that added to JSS delays but is outside of the responsibility of the political executive.

Moreover, while the competition for selecting the yards through the NSPS model may have been sound public policy (as it was routinely praised in 2011) relying on a shipyard like Seaspan, which had never built ships as large and complex as the Joint Support Ships or the CCG Polar Icebreaker, to undertake $\$ 8$ billion worth of new projects, made it almost certain that the JSS would not be delivered in a timely fashion. Even as of writing, Seaspan is still spending money modernizing its facilities and strengthening its engineering and management personnel numbers, five years after signing the umbrella agreement with the Harper government. In fact the

\footnotetext{
${ }^{130}$ Webb, Stewart. Returning To Port: A Needed Course Correction to Keep the National Shipbuilding Strategy off the Rocks. Toronto: The Mackenzie Institute, 2017.
} 
Harper government, on the very last day of the 2015 federal election, "quietly" approved a $\$ 40$ million grant to boost Seaspan's engineering and management skills; this decision was later supported by the Trudeau Liberals. ${ }^{131}$ The company's woes have naturally impacted the acquisition cycle of the JSS: the comparatively small size of the yard has meant the need for a prolonged redesign of TKMS's Berlin-class design to fit the confines of the Vancouver shipyard ( rather than the large Hamburg yard which it was designed for.) Similarly, the Harper government's opting for a proven, off-the-shelf design for the restarted JSS in 2010, led to oneand-a-half years of negotiations between the Secretariat and TKMS over the latter's intellectual property concerns. Navantia, the holder of the only other proven, off-the-shelf design, walked away out of frustration.

\footnotetext{
${ }^{131}$ Milewski, Terry. "Harper government gave Seaspan shipyard \$40M contract on election day." CBC News (Online), May 6, 2016. Accessible online: http://www.cbc.ca/news/politics/harper-shipbuilding-contract-election1.3568283 .
} 


\section{Chapter 4 - Medium Support Vehicle System - Standard Military Pattern}

\section{Introduction}

Buying logistics trucks for the Canadian Army (CA) should be one of the more straightforward projects for any government. Unlike Joint Support Ships or a new CF-18 replacement, logistics trucks typically do not involve cutting technology or cost billions of dollars to develop and operationalize. While Canada's procurement history is littered with highly technical and expensive projects gone awry (see the Avro CF-105 'Arrow') what became known as the Medium Support Vehicle System (MSVS) - Standard Military Pattern project became one of the more intractable procurements initiated during the Harper Conservative years.

Tracing its origins back to the Chrétien and Martin governments, the \$1.1 billion (later revised to $\$ 1.5$ billion) MSVS was officially launched as "one of the first procurement initiatives of the Canada First Defence Strategy announced in June 2006 to strengthen the CAF". ${ }^{1}$ The MSVS was created to replace the 2,764 two-and-a-half ton Medium Logistics Vehicle Wheeled (MLVW) trucks acquired by DND in 1982-1983. The MLVWs had a planned life span of fifteen years but successive refits had kept the fleet in service into the 2010s, albeit at reduced levels with just half the number of trucks available because of 'wear and tear', a lack of spare parts, and rust issues. $^{2}$

In keeping with a similar successful procurement approach used to acquire a replacement for the Iltis jeeps in 2003-2005, the MSVS encompassed four components, or phases, two of which were truck projects: a Military Commercial Off-the-Shelf (MilCOTS) truck fleet for the

\footnotetext{
${ }^{1}$ Canada. Department of National Defence. Chief Review Services. Internal Audit of Medium Support Vehicle System (MSVS) Project. Ottawa: 2014.

${ }^{2}$ Ibid.
} 
CA Reserve force, to be deployed only on domestic operations; and a Standard Military Pattern (SMP) fleet for the CA Regular force, to be deployed overseas. The MSVS project also included two complementary projects, one of which involved purchasing of 1,000 Special Equipment Vehicle shelters or 'kits'. Worth $\$ 155$ million of the original $\$ 1.1$ billion MSVS budget, the shelters came in five variants with 28 different configurations, including medical/dental units and command posts. The shelters can be fitted to the trucks transforming the "vehicle into a specialized unit such as a dental clinic or an equipment repair facility". ${ }^{3}$ The contract for the shelters was awarded in July 2009 to Ottawa-based DEW Engineering with deliveries completed in February 2015. ${ }^{4}$ A second project involved the acquisition of 300 trailers and 150 armour protection systems for the SMP trucks. A contract for these projects was awarded simultaneously with the SMP truck contract to U.S.-based Mack Defense in July $2015 .^{5}$

At their core, logistics trucks like the SMP are the 'lifeblood' of any army. Capable of traversing rough terrain and being deployed overseas to countries with rudimentary transportation infrastructure, the 1,537 trucks of the MSVS-SMP fleet are needed to move troops, ammunition, spare parts and supplies. The absence of such a capability can easily undermine the capacity of armies to deploy and support their forces in the field.

Between 2006-2012, the MilCOTS component of the MSVS project progressed relatively smoothly. The Request-for-Proposals (RFP) was issued in 2008 and a contract was awarded in

\footnotetext{
${ }^{3}$ Canada. Public Services and Procurement Canada. Land: Medium support vehicle system, accessed June 29, 2017 : https://www.tpsgc-pwgsc.gc.ca/app-acq/amd-dp/terre-land/index-eng.html. Author's note: the MSVS budget was later increased to \$1.5 billion to reflect the growth in cost of the SMP project in 2009.

${ }^{4}$ Canada. Industry Canada. Medium Support Vehicle System Project - Specially Equipped Vehicles - Baseline Shelters, accessed June 25, 2017: http://www.ic.gc.ca/eic/site/042.nsf/eng/aa00084.html; Canada. Department of National Defence and the Canadian Armed Forces. Medium Support Vehicle System Project, accessed June 25, 2017: http://www.forces.gc.ca/en/business-equipment/medium-support-vehicle.page.

${ }^{5}$ Mack Defense. "Mack Defense Awarded \$725 million CAD Contract to Supply More than 1,500 Trucks to the Canadian Armed Forces," accessed June 25, 2017: http://www.mackdefense.com/.
} 
January 2009 for 1,300 MilCOTS, 500 more than was originally planned for. Despite the RFP having been released for five months there was only one bidder, U.S. firm Navistar. ${ }^{6}$ All MilCOTS were delivered to CA Reserve units by fall $2012 .^{7}$

Their nine-and-a-half ton SMP cousins, however, encountered seven years of delays between the original implementation date in 2008, and when the contract was awarded in 2015 (see Table 4, page 120). The most common reasons provided for these delays was: internal DND-CA squabbling over truck specifications; a pause in 2009 to revise the RFP to account for technical, financial and market changes; and a cancelled RFP in July 2012 due to a redirecting of money by DND/CA from another related project into the SMP budget without informing the Treasury Board Secretariat or PWGSC. ${ }^{8}$ After 2012 a new RFP was written, accounting for the project's requirements changes and the budgetary increase from $\$ 1.1$ billion to $\$ 1.5$ billion. The new 1,500 page RFP included more than 500 mandatory technical requirements, it was released in July 2013 with a $\$ 834$ million contract awarded in July 2015 to Mack Defense (following six months of testing and evaluation in Nevada in 2014). As of writing, the first of the 1,537 SMP trucks are due to enter service in 2017-2019, however a successful complaint filed by Oshkosh Defense Canada (the only other bidder on the SMP project) with the Canadian International Trade Tribunal (CITT) over PWGSC handling of the latter's evaluation of the Oshkosh bid could lead to a costly payout above the $\$ 1.5$ billion MSVS program cost. ${ }^{9}$ Table 4 below provides an

\footnotetext{
${ }^{6}$ Canada. Parliament. House of Commons. Standing Committee on National Defence. Evidence. $2^{\text {nd }}$ Sess., $40^{\text {th }}$ Parliament, Meeting No. 2, February 9, 2009.

${ }^{7}$ Sloan. Something Has To Give: Why Delays Are the New Reality of Canada's Defence Procurement Strategy, 38.

${ }^{8}$ Canada. Department of National Defence and the Canadian Armed Forces. "Medium Support Vehicle System Project."

${ }^{9}$ Ibid.; Canada. Canadian International Trade Tribunal. Oshkosh Defense Canada Inc. v. Department of Public Works and Government Services, File Nos. PR-2015-051 and PR-2015-067 (Ottawa: 2016), 3, 52; Perry, 2015 Status Report on Major Defence Equipment Procurements, 52; Sloan, Something Has To Give, 38.
} 
overview of the key process milestones in the SMP project. The original dates established for advancing the project through the procurement process are compared to when they were actually achieved, or are planned to be achieved.

\begin{tabular}{|l|c|c|c|}
\hline \multicolumn{4}{|c|}{ Table 4 - MSVS (SMP) Project Milestones ${ }^{\mathbf{1 0}}$} \\
\hline \multicolumn{1}{|c|}{ Stage } & Original Date & $\mathbf{2 0 1 4}$ & Current Status \\
\hline Project Identification & October 20, 2000 & $\checkmark$ & $\checkmark$ \\
\hline Options Analysis Completed & July 15, 2004 & $\checkmark$ & $\checkmark$ \\
\hline Project Definition (PPA) & June 22, 2006 & $\checkmark$ & $\checkmark$ \\
\hline RFP Issued & October 2007 & July 2013 & $\checkmark$ \\
\hline Implementation (EPA) & November 2008 & 2015 & May 2015 \\
\hline \multicolumn{1}{|c|}{ First Delivery } & August 2009 & 2017 & Fall 2017 \\
\hline Final Delivery & August 2011 & 2018 & Spring 2019 \\
\hline Project Close Out & Spring 2013 & 2020 & December 2020 \\
\hline
\end{tabular}

\section{Political Executive Decisions}

\section{a. The Early Years (2000-2005)}

While DND and the CAF officially identified a MLVW replacement project in October 2000 the first political executive involvement pertaining to the project did not occur until 2003 when then Liberal defence minister John McCallum tentatively approved a DND/CAF plan to acquire new trucks from the U.S. Army. At the time, the Americans were planning a large buy of 83,000 trucks and, given the share size of the purchase, offered the CA the option to acquire 1,500 trucks at reduced cost. It was estimated that the U.S. Army proposal would have saved $\$ 300$

\footnotetext{
${ }^{10}$ Dates come from a combination of the following sources: Canada. National Defence: 2006-2007 Report on Plans and Priorities. Ottawa: 2006, 36; Canada. Department of National Defence and the Canadian Armed Forces. "Medium Support Vehicle System Project"; Canada. Treasury Board of Canada Secretariat. National Defence: 2007-2008 Status Report on Major Crown Projects (Ottawa: 2008); Perry, 2015 Status Report on Major Defence Equipment Procurements, 52.
} 
million when compared to the standard Canada procurement process of competitive tendering involving domestic firms and Industrial Regional Benefit offsets stipulations. ${ }^{11}$

However, the proposed plan faced stiff resistance from across government departments and domestic industry. The Chrétien government eventually opted not to support the foreign military sale when an Ottawa-based manufacturer, DEW Engineering and Development, expressed interest in bidding on the project. An inter-departmental review group made up of bureaucrats from IC, PWGSC, and regional economic development agencies agreed and pushed for the need to "create Canadian jobs and argued that an open competition must be held." 12 Consequently, the proposal was scuttled and DND planners and Land Force Command went revisited the project, delaying a decision on a MLVW replacement by at least two years.

The next political executive decision on getting new medium trucks came in the 2005 federal budget. Amid Paul Martin's \$13 billion defence spending injection, the Liberal government pledged $\$ 2.5$ billion for new medium-heavy lift helicopters, tactical-lift aircraft and, what the budget termed, a replacement for the "aging fleet of logistics trucks". ${ }^{13}$ Sparse on details and lacking an official project name, the Martin government recommitted to these procurement plans in its 2005 Defence Policy Statement with the call for "a new fleet of medium transport trucks". ${ }^{14}$ Like their transformation plans for the JSS, the new trucks were to be part of a larger effort to turn the army into "a modern, combat capable, medium-weight force". For the army, the trucks would complement and support a new fleet of army vehicles set to replace the

\footnotetext{
${ }^{11}$ Sloan, Something Has To Give, 38-39; Pugliese, David. “Shop at home policy adds \$300 million to Forces' truck costs." The Ottawa Citizen, February 2, 2004, A1.

${ }^{12}$ Sloan, Something Has To Give, 38-39; Pugliese, "Shop at home policy adds $\$ 300$ million to Forces' truck costs."

${ }^{13}$ Canada. Department of Finance. The Budget Plan 2005. Ottawa: 2005, 220-222.

${ }^{14}$ Canada. Department of National Defence. Canada's International Policy Statement: A Role of Pride and Influence in the World - Defence. Ottawa: 2005, 15.
} 
CA's heaviest vehicles, the thirty year-old Leopard I tanks and M-109 self-propelled howitzers, with sixty six Mobile Gun Systems and thirty three Multi-Mission Effects Vehicle, all based on the popular Light Armoured Vehicle (LAV) III chassis. With a planned purchase of new C-130J transport aircraft for the air force's transport fleet, the plan was for the new logistics trucks and armoured vehicles to be transportable by air transport providing a rapid deployable force to global hot spots at short notice. ${ }^{15}$

A Memorandum to Cabinet in November 2005 proposed a fast-tracking of the new transport trucks along with several major aircraft procurement projects like a new Fixed-Wing Search-and-Rescue (FWSAR) plane. Cabinet ministers, allegedly prompted by their senior bureaucrats, became concerned about the dollar size of the projects and the fact that some, like the FWSAR, would be sole-sourced projects acquired without competition and possibly at the expense of domestic industry. Consequently, the proposal was rejected and punted off until the end of the federal election that was called several weeks later. ${ }^{16}$ Notably, the Martin-led Liberals referenced "logistics trucks" in their campaign platform as part of their transformative defence policy commitments. In contrast, the Stephen Harper-led Conservatives gave the project little attention. ${ }^{17}$

\section{b. The Early Harper Years (2006-2009)}

As noted in Chapter Three, the Conservatives' defence election platform was titled 'Canada First'; was authored by retired brigadier general and now defence minister, Gordon O'Connor.

\footnotetext{
${ }^{15}$ Collins, "The Perpetual Search for Efficiency: The Canadian Approach to the RMA and Military Transformation", 51-70.

${ }^{16}$ Hillier, General Rick. A Soldier First. Toronto: Harper Collins Publishers Ltd., 2009, 348-350; Confidential source, Telephone interview with the Author, January 5, 2017.

${ }^{17}$ Liberal Party of Canada. Securing Canada's Success (Ottawa: 2006), 73.
} 
O'Connor was instructed by Stephen Harper to implement the key procurement plans outlined in Canada First, specifically the acquisition of the strategic and tactical lift aircraft for the air force. ${ }^{18}$ Outside of these transport aircraft, and the planned purchase of new icebreakers and Arctic patrol ships for the navy, there was no mention of replacing the army's MLVWs or buying new fleets of army equipment during the election. In fact, the Conservatives never got too specific on pledging anything to the army beyond increasing troop numbers, preferring to adhere to the generic slogan of building a "multi-role, combat capable defence force". ${ }^{19}$ One possible reason for the lack of army projects was that the armed service, unlike its air force counterparts, had benefitted from a recent recapitalization of multiple fleets of armoured vehicles. In fact, most of Land Force Command's 1,500 light armoured vehicles, including Coyote reconnaissance vehicles and LAV IIIs, had been acquired in the 1990s. Moreover, the much maligned Iltis jeep which had been in the news for years because of its vulnerabilities to small arms fire and landmines on operations in the Balkans and Afghanistan had been replaced between 2003 and 2005 with a Land Force Command Reserve force MilCOTs fleet of Silverados, built by General Motors Canada, and a Mercedes Benz 'G-Wagen' SMP fleet for the Regular force. ${ }^{20}$ In this sense, it would have been a challenge to embarrass the Liberals' for their dealings on army equipment in 2005-2006 considering that by then Land Force Command had been the beneficiary of multiple fleet renewal projects. ${ }^{21}$ Finally, in contrast to well publicized problems

\footnotetext{
${ }^{18}$ Hillier, A Soldier First, 395, 398; Carson, Bruce. 14 Days: Making the Conservative Movement in Canada. Montreal-Kingston: McGill-Queen's University Press, 2014: 96, 130.

${ }^{19}$ Conservative Party of Canada. Stand Up For Canada (Ottawa: 2006), 45; A version of this slogan appeared, ironically enough, in the Chretien Liberal government's 1994 White Paper on Defence.

${ }^{20}$ Replacing the Iltis is itself a story of delays and political interference. For more, see: Kim Richard Nossal, Charlie Foxtrot: Fixing Defence Procurement in Canada (Toronto: Dundurn, 2016), 44-54; Alan Williams, Reinventing Canadian Defence Procurement: A View from the Inside (Toronto: Breakout Education Network, 2006), 9-10.

${ }^{21}$ New or updated fleets by 2005 included the $\$ 358$ million M113 (Armoured Personnel Carrier) Life Extension, the \$225 million Light Utility Vehicle Wheeled project (Iltis replacement), the \$2.2 billion LAV III Armoured Personnel Carrier project, and the \$211 million modernization of the Bison and Armoured Vehicle General Purpose
} 
with the Iltis the problems associated with the deteriorating MLVWs received little media or public attention before or during the election campaign.

Upon taking office minister O'Connor ordered a freeze on existing Martin-era procurement plans pending the completion of a review of these projects and whether they aligned with what had been laid out in the Canada First campaign plans. In the interim, the Harper government added $\$ 5$ billion (over five years) in defence spending in their first budget in 2006 . This money was over and above the $\$ 13$ billion the outgoing Liberals' had already allocated to defence. By the end of spring the review was complete and on June 29, 2006 the Conservatives unveiled their first set of major procurement plans. Under the rubric of a 'Canada First Defence Strategy', minister O'Connor announced the planned expenditure of $\$ 17.1$ billion in new equipment and related supports. At the heart of the announcement were what the Chief of Defence Staff (CDS) General Rick Hillier referred to as the 'Big Four': three new Joint Support Ships for Maritime Command; strategic and tactical airlift plus medium-heavy helicopters for Air Command; and "medium-sized logistics trucks" for Land Force Command. ${ }^{22}$

The Harper government's decision to incorporate what became known as the MSVS project into the June 2006 announcement was partly driven by a recognition that the MLVWs were aging and required replacement soon. There was concern they would become a major operational liability for the CAF, which was now having to rely more on the trucks for its deployment to the war in Afghanistan. However, the MSVS's inclusion was also a reflection of the Harper government's desire to have a major army project included in their Canada First

fleets. See: Canada. Department of National Defence, Department of National Defence: 2003-2004 Report on Plans and Priorities: Status Report on Key Capital Projects (Ottawa: 2003).

${ }^{22}$ Hillier, A Soldier First, 400; Canada. Department of National Defence, Canada. National Defence. "'Canada First" Defence Strategy Procurement. accessed February 13, 2017:

http://www.forces.gc.ca/en/news/article.page?doc=canada-first-defence-strategy-procurement/hnocfo8n. 
procurement announcement; in short, there was a communications impetus for announcing the MSVS project as up to this point the Canada First plans were heavy on navy and air force projects. ${ }^{23}$ In a likely attempt to distinguish themselves from their Liberal predecessors who failed to get the projects approved before the election, the Harper Conservatives framed the MSVS and its Big Four cousins as "key capabilities [...] long overdue" to be acquired at the "right price for Canadians, with the right benefits for Canadian industry." 24 The MSVS went through cabinet as a part of the Big Four package of acquisitions announced in June 2006. At the time, government officials did not see the need for the project to go up to cabinet as a standalone MC given "its somewhat lower cost and lower risk as well as lower visibility"; this is in contrast to the $\$ 650$ million Leopard II tank purchase in 2007 which was seen as necessitating its own MC despite having a lower cost. ${ }^{25}$

The Conservatives' MSVS announcement detailed a project budget of $\$ 1.1$ billion with an additional \$100 million for twenty years worth of in-service support. Minister O’Connor described the project as "urgent" with "[d]elivery expected as soon as possible". Unlike the Chrétien and Martin-era sole source efforts, the Conservatives' MSVS plan specifically involved buying two classes of trucks instead of one - the same approach used to replace the Iltis discussed earlier. There would be 1,500 SMP trucks for the regular army and a separate fleet of 800 (later increased to 1,300) military out-fitted commercial off-the-shelf trucks (MilCOTS) for the army reserves. These latter trucks were designated for domestic operations and for training and transport functions with the Land Force Command Reserves' 130 units scattered across the

\footnotetext{
${ }^{23}$ Senior government official, Telephone interview with the Author, December 8, 2016.

${ }^{24}$ Canada, Department of National Defence, "'Canada First' Defence Strategy Procurement".

${ }^{25}$ Senior government official, Confidential in-person interview with the author, September 23, 2016.
} 
country. ${ }^{26}$ The former SMP trucks were slated for service with regular army units deployed overseas in harsh operational conditions like Afghanistan. Complementing the SMP trucks were 1,000 Special Equipment Vehicles shelters (kitchens, dental and medical stations, etc...) and 300 (later reduced to 150) armour protection systems to assist the trucks in operating in conflict zones like Afghanistan or, previously the Balkans, where road-side bombs and landmines inflicted severe casualties on army units. ${ }^{27}$ Altogether, Land Force Command would receive 2,300 trucks of both types, of which $\$ 430$ million was budgeted for the 1,500 SMP trucks and \$274 million for 800 MilCOTS with the remaining money allocated to the vehicle kits and armour protection systems. ${ }^{28}$ The SMP contract was slated for June 2008 with deliveries taking place over the winter of $2010-2011 .^{29}$

When it came to the MSVS project as whole, a key distinction between the Harper political executive at this time and their Liberal predecessors was the absence of a clearly defined role for the new SMP trucks. The Martin government's Defence Policy Statement envisioned a medium truck fleet capable of being transported by new C130J tactical transport aircraft as part of transformed, medium-weight CAF. The Conservatives, however, provided no such policy context or vision statement describing the trucks' role within either the CAF or defence policy more generally. ${ }^{30}$ In fact, the MSVS project emerged as the only Martin-era army fleet project kept alive by the Conservatives following their ascension to power in 2006. After

\footnotetext{
${ }^{26}$ Canada. Parliament. Senate. Standing Committee on National Security and Defence. "Answering The Call: The Future Role of Canada's Primary Reserve," $1^{\text {st }}$ sess., $41^{\text {st }}$ Parliament, Report No. 4, December 11, 2012; Canada. National Defence and the Canadian Armed Forces. Canadian Army Reserve. accessed June 27, 2017: http://www.army-armee.forces.gc.ca/en/reserve/index.page.

${ }^{27}$ Canada, Department of National Defence, "'Canada First' Defence Strategy Procurement".

${ }^{28}$ Pugliese, David. "Delayed trucks now due in 2017." The Ottawa Citizen, May 4, 2015, A6.

${ }^{29}$ Canada. Department of National Defence. National Defence: 2006-2007 Report on Plans and Priorities. Ottawa: 2006, 26.

${ }^{30}$ Confidential Source, Telephone interview with the Author, February 16, 2017.
} 
O'Connor's procurement review, the twin impact of Taliban attacks on the army's light armoured vehicles in Afghanistan and the purchase of large CC-177 strategic lift aircraft capable of flying tanks and heavy vehicles than the C-130J, caused the CA to recommend the elimination of both the Mobile Gun System and the Multi-Mission-Effect Vehicles (the latter of which had a $\$ 753$ million budget) in favour of maintaining the heavier Leopard I tank. (The older tanks were eventually replaced with 100 surplus Dutch Leopard II tanks in 2007 and several fleets of mineresistant vehicles like the RG-31 Armoured Patrol Vehicle and the Armoured Heavy Support Vehicle System. ${ }^{31}$ )

In contrast, the only real connection between the MSVS trucks and any operational role was in determining the number of SMP trucks necessary to meet the Conservative's Canada First troop expansion goals announced on the campaign. As a part of their platform, and reiterated again in June 2006, the Harper Conservatives planned to expand the CAF's personnel numbers by 4,000 regular force and 4,000 reserve members. Internally, DND estimated that an additional 650 SMP trucks, on top of the planned 1,500 announced in 2006, were needed to meet the demands of the earlier personnel expansion but the necessary funding was never provided. ${ }^{32}$

With the project now sanctioned there was no more political executive involvement until May 2008 when the Conservative government released their first official defence policy, the Canada First Defence Strategy. Light on specifics, but endorsed by the prime minister, the CFDS merely recommitted the government to getting 2,300 trucks of both MilCOTS and SMP varieties using the dollar amounts established in 2006. The CFDS described the truck project as a

\footnotetext{
${ }^{31}$ Canada. Office of the Auditor General of Canada, Chapter 5: Acquiring Military Vehicles for Use in Afghanistan (Ottawa: Fall 2009); Canada. Treasury Board Secretariat. Status Report on Major Crown Projects for fiscal year 2006-2007 (Ottawa: 2007); “Tanks for the Lesson: Leopards, too, for Canada.” Defense Industry Daily. accessed June 27, 2017. http://www.defenseindustrydaily.com/tanks-for-the-lesson-leopards-too-for-canada-03208/. ${ }^{32}$ Canada, Internal Audit of Medium Support Vehicle System (MSVS) Project. Ottawa: 2014, ii, 1.
} 
part of "urgently needed equipment" like the C-17s, JSS, and CH-47F Chinook helicopters, to be used for increasing "the deployability of the military" ${ }^{33}$ Crucially, although it was not specifically identified at the time, the CFDS also included a separate truck project later recognized as the Logistics Vehicle Modernization (LVM) project. The LVM was a part of the CFDS's planned expenditure of \$20 billion for new "Land Combat Vehicles and Systems". ${ }^{34}$ The aim of this still ongoing project is to replace the one-and-a-half-ton Light Support Vehicle Wheeled and ten-ton Heavy Logistics Vehicle Wheeled fleets, both of which are lacking sufficient armoured protection and unable to be deployed for overseas operations. ${ }^{35}$ The 2008 CFDS was the extent of political executive involvement in the MSVS project for the next four years.

\section{c. The Later Harper Years (2010-2015)}

After the release of the CFDS in 2008, the SMP project remained in the project definition stage and therefore under the purview of DND and the army. Time spent by DND and the military developing the SMP's Statement of Requirements (SOR) pushed the RFP release date back by four years from 2007 to late-2011. However, in July 2012, just six months after the RFP was released in late 2011, PWGSC, in a decision supported by officials in the Prime Minister's Office and the Treasury Board Secretariat (TBS), made the decision to cancel the RFP altogether, forcing DND and Land Force Command to go back and rewrite the SOR, and adding another year of delay. The chief culprit was cost escalation, specifically in that the SMP project budget had grown 40 percent due to the inclusion of expensive heavy armour protection systems.

\footnotetext{
${ }^{33}$ Canada. Department of National Defence. Canada First Defence Strategy. Ottawa: 2008, 4, $12,16$.

${ }^{34}$ Ibid., 12.

${ }^{35}$ Canada. Internal Audit of Medium Support Vehicle System (MSVS) Project (Ottawa: 2014); Poulter, Major General. "Canadian Army Support Vehicles." U.S. Department of Defense: Defense Technical Information Centre, February 6, 2012: http://www.dtic.mil/ndia/2012/tactical/poulter.pdf - 2012-02-16.
} 
The SMP budget now sat between $\$ 730$ million and $\$ 800$ million, up from the $\$ 430$ million established in 2006. While SMP project officials had accounted for the cost increase by allocating money to their budget from another future truck project, the LVM, they did so without informing PWGSC or the TBS. ${ }^{36}$ This action by DND and the army drove PWGSC's decision to push for a cancellation at the last minute.

From a political executive viewpoint, the 2012 RFP cancellation came during a time of much parliamentary and media scrutiny over problematic procurement projects. In 2011-2012 two damning reports were issued by the Parliamentary Budget Officer and the Auditor General, respectively, that called into question the accuracy of financial information and DND's forthrightness to political officials over the costs of the F-35 program. ${ }^{37}$ The combination of these reports and another separate 2010 Auditor General's report that found fault with cost overruns in the Chinook medium-heavy lift helicopter project, convinced political officials to support the cancelation of the RFP so as to avoid "another publicly embarrassing military procurement". ${ }^{38}$ Once the decision to cancel the RFP was made the procurement process returned to DND, the CA and PWGSC. The next and final political executive involvement came in July 2015 when Treasury Board gave the SMP effective project approval to the winning and sole-bidder, Mack Defense LLC of Allentown, Pennsylvania. ${ }^{39}$

\footnotetext{
${ }^{36}$ Sloan, Elinor. "Canadian Defence Commitments: Overview and Status of Selected Acquisitions and Initiatives." Calgary: CDFAI, et al., 2013, 25-26; Confidential Source, Telephone interview with the Author, February 16, 2017. ${ }^{37}$ Canada. Office of the Parliamentary Budget Officer. An Estimate of the Fiscal Impact of Canada's Proposed Acquisition of the F-35 Lightning II Joint Strike Fighter (Ottawa: 2011); Canada. Office of the Auditor General of Canada, Chapter 2: Replacing Canada's Fighter Jets (Ottawa: Spring 2012).

${ }^{38}$ Pugliese, "Extra \$300M killed truck project", A1.

${ }^{39}$ Canada. Department of National Defence, "Government of Canada Awards Major Military Procurement Contracts for New Trucks". accessed February 16, 2017. http://news.gc.ca/web/article-en.do?nid=1001579; Canada. Department of National Defence and the Canadian Armed Forces. "National Defence: 2015-2016 Report on Plans and Priorities" (Ottawa: 2015); Canada, Department of National Defence and the Canadian Armed Forces. Internal Audit of Medium Support Vehicle System (MSVS) Project (Ottawa: 2014), ii.
} 


\section{Exogenous Factors}

\section{a. Defence Procurement Bureaucracy}

$\underline{D N D / C A F}$ : The inability of DND and Land Force Command to come to a timely agreement on the requirements for the SMP added close to four years to the SMP project. From the army's perspective, the key motivation was to replace the MLVW fleet acquired in 1982-1983 when the Pierre Trudeau government purchased 2,764 two-and-a-half ton trucks from Quebec-based Bombardier Inc. for $\$ 150$ million. ${ }^{40}$ Based on a 1950 s U.S. cargo truck design, the M35, the MLVW satisfied the army's need for a vehicle with specific tactical requirements (such as rigid suspensions and specialized off-road tires) necessary to operate as the backbone of the army's transport fleet. ${ }^{41}$ Rugged and capable of deploying overseas in harsh terrain the MLVWs originally had a planned service life of just 15 years. By the early 2000 s the combination of age and operational 'wear and tear' had seen per kilometre maintenance costs increase by a factor of five. Corrosion was taking its toll as well. A spray program was introduced to soften the impact but, as a 2006 DND report concluded, within two years the:

fleet will become increasingly unsupportable due to a combination of various problems including parts availability, continued advancement of corrosion, performance of the brake system and vehicle overloading. ${ }^{42}$

Knowing that the MLVW fleet would be reaching the end of its life in the late-1990s, DND began identifying the need to replace the aging trucks with an unnamed replacement project

\footnotetext{
${ }^{40}$ McDougall, Stephen. “Army shrinks, downgrades truck fleet.” Sherbrooke Record, January 12, $2009,5$.

${ }^{41}$ Military Today. "MLVW: Light utility truck." accessed April 3, 2017: http://www.militarytoday.com/trucks/mlvw.htm.

${ }^{42}$ Canada. Department of National Defence. National Defence: 2006-2007 Report on Plans and Priorities (Ottawa: 2006), 26.
} 
officially approved in October 2000. Given the MLVWs' deteriorating condition DND and the CAF, especially the Canadian Army, as the agencies solely interested in the capabilities of the trucks, wanted to replace the aging MLVWs as soon as possible. The project was deemed 'urgent' due to the vital role the MLVWs fulfilled as the backbone of the army's logistic and transport capabilities for operations both at home and abroad. It is within this context that the CA and the DND made the pitch to the Martin government for buying 1,500 trucks from the U.S. Army. While the sole-source project failed because of domestic industrial and inter-departmental opposition, the Martin government supported the project in its 2005 budget and positioned what became the MSVS within its Defence Policy Statement (DPS) vision of a medium-weight transformed CAF with a new medium truck that could be transportable in a C-130J aircraft. ${ }^{43}$ The chief proponent of the DPS was CDS Rick Hillier. Hillier saw a CAF that was more integrated and specialized than the Cold War thinking that had underpinned the military's organizational structure and doctrine since the Korean War. Hillier's vision, encapsulated in the Defence Policy Statement was to have the CAF capable of conducting 'Three Block War' in an built-up urban environment in countries with little to no working infrastructure. ${ }^{44}$ According to Hillier, a key part of this transformed CAF was replacing the army's “old and worn transport trucks". ${ }^{45}$

The face of the government may have changed but the impetus for replacing the MLVWs remained. Once announced in June 2006, the MSVS took the shape of multiple truck projects. The MilCOTS were straightforward: an existing commercial truck design, already in production,

\footnotetext{
${ }^{43}$ Confidential source, interview with the Author, February 16, 2017.

${ }^{44}$ Stein, Janice Gross and Eugene Lang. The Unexpected War: Canada in Kandahar. Toronto: Penguin Canada, 2007, 147-149.

${ }^{45}$ Hillier, A Soldier First, 348-349.
} 
was customized to meet the needs of the army reserves. Like their Silverado LUVW

counterparts, the MSVS MilCOTS trucks were not sanctioned for overseas operations and hence did not require a complex design that could meet the demands of army regular units overseas where countries like Afghanistan had illustrated the necessity of trucks having armour protection and a durable vehicle frame to withstand blasts from improvised explosive devices (IEDs), poor road infrastructure and rugged terrain.

In contrast to the MilCOTS, the SMP was shrouded in ambiguity from the start as a result of the rushed request by the Conservative government to include a major army project in their June 2006, \$17 billion Canada First procurement announcement. There was a concern that the announcement not be seen as too heavily slanted towards the RCAF and the RCN. ${ }^{46}$ Therefore, the SMP trucks was approved with little in the way of clarity as to its requirements. This set the basis for the project to become subject to alteration once the impact of other acquisitions, the global marketplace, and the Afghanistan war began making themselves felt. To quote one observer, at the time the SMP was "not really explained, [with] details all over the place". ${ }^{47}$

The sole-source purchase of four CC-177 strategic lift aircraft in 2006-2007 (a fifth was acquired in 2015) influenced changes in the project's SOR, helping push the SMP beyond its original $\$ 430$ million budget. The load carrying capacity of the CC-177s, 164,000 pounds of cargo versus the CC-130J's 48,000 pounds, incentivized army planners to think big with the SMP. ${ }^{48}$ Before long Land Force Command was replacing two-and-a-half ton MLVW trucks with

\footnotetext{
${ }^{46}$ Senior government official, telephone interview with the Author, December 8, 2016; Confidential Source, telephone interview with the author, January 23, 2017.

47 Subject Matter Expert \#1, Telephone interview with the Author, September 28, 2016. A similar view was echoed during a telephone interview between a confidential source and the author on 16 February 2017.

${ }^{48}$ Confidential source, Telephone interview with the Author, December 8, 2016; Canada. Department of National Defence and the Canadian Armed Forces. "Royal Canadian Air Force: Aircraft.” accessed June 26, 2017 : http://www.rcaf-arc.forces.gc.ca/en/aircraft.page.
} 
specifications written for an eight-to-nine ton truck. Such an increase ignited internal debates in the army and DND around what exactly a 'medium' truck entailed versus a 'light' or 'heavy' truck; a point that became more acute as the size and weight of the SMP trucks came within range of the army's existing ten ton 'heavy' trucks, the Heavy Logistics Vehicles Wheeled (HLVW) ${ }^{49}$ The ripple effect of this comparison prolonged discussions between the army and defence bureaucracy on whether the SMP should have six or eight axles, the latter of which were necessary for adequate weight distribution so as to avoid getting stuck when operating off road. ${ }^{50}$ Of course, by increasing the number of axles the army increased the per-unit cost of trucks exponentially. For example, it was estimated that a $6 \times 6$ truck from Mercedes, a potential bidder, cost $\$ 300,000$ while an $8 \times 8$ came close to $\$ 1$ million. ${ }^{51}$ Another financial effect was the designs for the 1,000 shelters. For every increase made in truck size and tonnage, changes had to be made to the shelter designs. Effectively, larger trucks equated to larger shelters. An undisclosed amount of time and resources were subsequently spent on making those necessary alterations to the MSVS shelter project so that whatever variant of shelters used did not detrimentally impact the weight distribution on the chassis, potentially causing the trucks to tip over.

Tensions also existed within the army itself, as officials struggled to sort out competing priorities and the impact of the Afghanistan mission. ${ }^{52}$ In short, the evolving nature of the counter-insurgency war in Afghanistan illustrated that the early SMP requirements were "not up to scratch" further compounding the inability of the army and DND to reach an internal consensus on the SOR which led the army to keep "monkeying with requirements". ${ }^{33}$ One area

\footnotetext{
${ }^{49}$ Confidential Source, Telephone interview with the Author, February 16, 2017.

50 Ibid.

${ }^{51}$ Ibid.

${ }^{52}$ Confidential Source, Email interview with the Author, November 30, 2016.

${ }^{53}$ Confidential Source, Telephone interview with the Author, January 23, 2017.
} 
of concern that emerged out of the war was the degree of armoured protection needed. Armour, however, is expensive and by adding more the project cost nearly doubled "as is the case with all modern militarized trucks, lots of money went into developing the cab in order to survive a bomb". Another issue was the shock resiliency of the trucks - which is reduced when the amount of armour is increased, - as well as the installation of advanced communications gear. ${ }^{54}$ Adding to these challenges was the fact that producing a cost estimate based on these alterations became much harder after 2006 due to the increased demand in the international truck market; Canadian allies were buying more vehicles to meet their own commitments in Iraq and Afghanistan. ${ }^{55}$

Moreover, questions on the scope of the SMP's requirements persisted in relation to their possible usage by other branches of the CAF. For instance, if the MSVS MilCOTS were meant for domestic use only, did the interests of the air force and navy need to be taken into account for the SMP project even though air force and naval usage was predominantly confined to CFBs in Canada? What about the special forces branch of the CAF which traditionally relied upon lightweight easily deployable vehicles for clandestine missions? The fact that the SMPs' roles were never explained in the CFDS or in the previous Conservative June 2006 announcement meant that explanations as to the capabilities and the types of truck variants needed went unanswered, consuming time and contributing to the delays experienced between 2006-2012 during the project definition phase. ${ }^{56}$ Within DND some senior officials viewed these debates as indication that the MSVS was approved by the political executive too early and without enough thought given to the what exactly the trucks roles and requirements should be. ${ }^{57}$ Others, like ADM (Mat)

\footnotetext{
${ }^{54}$ Confidential source, Telephone interview with the Author, December 8, 2016.

55 Ibid.

${ }^{56}$ Subject Matter Expert \#1, Telephone interview with the Author, September 28, 2016; Subject Matter Expert \#2, Telephone interview with the Author, October 5, 2016.

${ }^{57}$ Confidential Source, Telephone interview with the Author, December 8, 2016.
} 
Dan Ross thought that the army was intentionally "over specifying" the trucks. In testimony before the Standing Committee on National Defence in 2007 he expressed his frustration at SMP army planners: "I said, 'Come back to me and tell me what you want it to do. Don't tell me how many mirrors and how big the mirror has to be". 58

Project definition also suffered from personnel pressures. Within DND the MSVS project management office was seen as understaffed considering the number of interrelated projects they were being asked to undertake. ${ }^{59}$ Such human resource problems in the project office were identified in DND's own 2006-2007 Report on Plans and Priorities as a contributing factor in delaying the development of the SMP's requirements. ${ }^{60}$ Understaffing issues were a concern in the inter-departmental arena as well. MSVS project staff had to contend with PWGSC who some felt were, in their attempt to maximize as many competitive contracting opportunities with the MSVS's various components (see next section), in essence ignoring DND's concerns. All of this debate was time consuming. ${ }^{61}$

The overall effect of these alterations was not only a prolonged project definition stage but also a 40 percent increase in the SMP's budget. ${ }^{62}$ With requirement alterations and cost increases DND officials initially thought they had to return to the Treasury Board cabinet committee with a revised Preliminary Project Approval. ${ }^{63}$ However, to avoid going to Treasury

\footnotetext{
${ }^{58}$ Canada. Parliament. House of Commons. Standing Committee on National Defence, Evidence, $1^{\text {st }}$ Session, $39^{\text {th }}$ Parliament, Meeting No. 34, February 8, 2007.

${ }^{59}$ Senior government official, Telephone interview, December 8, 2016.

${ }^{60}$ Canada. Department of National Defence. National Defence: 2006-2007 Report on Plans and Priorities (Ottawa: 2007), 26; Subject Matter Expert \#1, Telephone interview with the Author, September 28, 2016.

${ }^{61}$ Confidential Source, Telephone interview with the Author, December 8, 2016.

${ }^{62}$ Sloan, Something Has To Give, 38.

${ }^{63}$ Ibid.; Department of National Defence. "Medium Support Vehicle Project (MSVS)", 2009-2010 Status on Major Crown Projects; Pugliese, "Extra \$300M killed truck project", A1; Department of National Defence. "Medium Support Vehicle Project (MSVS)", 2011-2012 Status on Major Crown Projects; Perry, 2015 Status Report on Major
} 
Board with a new submission the commander of Land Force Command, Lieutenant General Andrew Leslie, authorized the transfer of funds away from the future LVM project to the SMP budget in 2009. This approach was partly justified on the need to replace the decaying MLVWs, a pressing issue for the army since the 1990s, and a recognition that the capabilities sought in the SMP overlapped with some of those of the heavy truck replacement to be acquired under the LVM project. ${ }^{64}$ While DND felt it had the "policy coverage" to take this action, this decision was not communicated to the Interdepartmental Oversight Committee - which featured representatives from PWGSC and IC and was tasked with overseeing military Major Crown Projects. ${ }^{65}$ Consequently, DND and army actions pertaining to this cash reallocation became the driving force behind the July 11, 2012 PWGSC and political executive decision to cancel the RFP and restart. ${ }^{66}$

With three minutes to go before the submission deadline closed, PWGSC officials, specifically Tom Ring, the ADM for Procurement, ordered the cancellation of the RFP and bidders were notified by email. In some cases, industry bidders had already dispatched their truck prototypes to the Nevada Automotive Test Centre when the cancellation decision was made. ${ }^{67}$ Another year of DND industry consultation followed as was required, before the project definition stage was completed and a new RFP was issued. ${ }^{68}$

\footnotetext{
Defence Equipment Procurements, 51; James Cudmore, "Military truck purchase cancelled due to cost concerns", CBC News, July 11, 2012.

${ }^{64}$ Confidential source, Telephone interview with the Author, February 16, 2017; Subject Matter Expert \#2, Telephone interview with the Author, October 5, 2016.

${ }^{65}$ Canada. Internal Audit of Medium Support Vehicle System (MSVS) Project (Ottawa: 2014), iii; Confidential source, Telephone interview with the Author, February 16, 2017.

${ }^{66}$ Department of National Defence. "Medium Support Vehicle Project (MSVS)", 2012-2013 Status on Major Crown Projects; Perry, 2015 Status Report on Major Defence Equipment Procurements, 51.

${ }^{67}$ Cudmore, "Military truck purchase cancelled due to cost concerns"; Confidential source, Telephone interview with the Author, February 16, 2017.

${ }^{68}$ Canada. Internal Audit of Medium Support Vehicle System (MSVS) Project (Ottawa: 2014), 2.
} 
PWGSC: As with its role in the JSS and FWSAR projects, PWGSC's role in the SMP project was first and foremost protecting the contracting process. In some corners of the government this led to blunt, non-complimentary views of the department with one former senior official stating that when it came to the SMP project, "Public Works is the problem." 69 Likewise, PWGSC's steadfast adherence to its mandate was viewed in defence circles as indicative of a department with the wrong priorities: the "process is more important than [the] outcome. You get what you want or you get nothing." ${ }^{, 70}$ In the context of the whole MLVW replacement history there is some truth to these views. PWGSC helped defeat the 2003-2004 Land Force Command proposal to sole source a replacement for the MLVWs on the basis that an open competition was necessary and would do so again in 2005 when the Martin cabinet scuttled an attempt to purchase new trucks as part of a large procurement pitch from DND/CAF for the same reasons.

From the beginning of the MSVS project in 2006, PWGSC insisted on maintaining the need for an open and fair competition. At one point, early in the process, PWGSC officials informed DND that 13 separate contracts would be necessary for the MSVS project but DND pushback saw this reduced to four: the MilCOTS, shelters, armoured protection systems, and the SMP. In favouring 13 contracts PWGSC had asked that the shelters contract be broken down further into multiple, smaller contracts by shelter type. For example, a contract for shelters configured for field kitchens, another for medical services, etc.... ${ }^{71}$ The combination of multiple factors likely influenced PWGSC's view towards opening the MSVS to as many possible bidding opportunities as possible, which characterized the department's approach to the SMP. First and foremost was the fact that CAF had long purchased Canadian-made trucks, including

\footnotetext{
${ }^{69}$ Senior government official (ret'd.), Telephone interview with the Author, September 26, 2016.

${ }^{70}$ Confidential source, Telephone interview with the Author, January 22, 2017.

${ }^{71}$ Confidential source, Telephone interview with the Author, December 8, 2016.
} 
right up to 2003-2005 with the Iltis replacement. Secondly, because such trucks tend to be less technologically sophisticated than planes or ships the MSVS project represented a strong opportunity to leverage domestic value from more local bidders. Thirdly, past attempts at a solesource truck bid in the previous Liberal governments met domestic industry opposition. Hence, proceeding with an unimpeachable RFP avoided industry complaints. And finally, especially with the end of combat operations in 2011, there was a feeling within PWGSC that DND and the CAF had circumvented the competition process too many times with Afghanistan-related UORs which predominantly went to mostly foreign companies (like Boeing's CC-177s and the German-made but Dutch-owned Leopard II tanks). ${ }^{72}$

Concerned that they would not be able to fully testify to the fairness and openness of any competition due to the budgetary changes enacted in 2009 by DND, PWGSC opted to cancel the RFP. As one source noted, when it comes to fairness, once it is called into question "a project is done". ${ }^{73}$ Thus, for ADM Tom Ring, PWGSC's procurement chief, the priority of his department “was for [an] open, fair competition”, while his DND counterpart, ADM (Mat) Dan Ross, was focused on obtaining "gear for [the] troops". ${ }^{74}$ PWGSC justified the cancellation on the grounds of changed "economic, marketplace and budgetary circumstances...since this solicitation process began" ${ }^{75}$ Following the 2012 RFP cancellation, the next eighteen months were spent consulting industry on SMP requirements and probable costs all in order to ensure that the integrity of the competition would not be claimed to be unfair against any one bidder. ${ }^{76}$

\footnotetext{
${ }^{72}$ Confidential source, Telephone interview with the Author, December 1, 2016.

${ }^{73}$ Confidential source, Telephone interview with the Author, January 22, 2017.

${ }^{74}$ Confidential source, Telephone interview with the Author, February 16, 2017.

75 The Canadian Press. "Military truck purchase cancelled due to cost concerns," CBC News, http://www.cbc.ca/news/canada/military-truck-purchase-cancelled-due-to-cost-concerns-1.1273570.

${ }^{76}$ Senior government official, Telephone interview with the Author, December 8, 2016.
} 
IC: Unlike DND or PWGSC, IC's role in the SMP project was circumstantial. Firstly, as a part of the department's mandate, its officials remained focused on ensuring that the government's Industrial Regional Benefits (IRB) policy were being adhered to. With the MSVS project, IRBs applied to the MilCOTS, the add-on truck shelters, and the SMP contracts. The policy did not apply to the kitting contract "due to international trade agreements". ${ }^{77}$ Throughout the SMP project IC's role was largely regulated to just providing 'yes/no' answers to bidders' IRB proposals.

Secondly, IC was to provide knowledge to DND on the state of the international military truck marketplace. This proved a consistent problem in the early years of the project when the market dynamics shifted suddenly due to the increase in operational tempo with wars in Iraq and Afghanistan: soon "everyone in NATO wanted trucks". ${ }^{78}$ Moreover, just as the MSVS project was launched in 2006, the payloads for trucks in allied armies was growing. ${ }^{79}$. IC's weakness at understanding the marketplace was further hampered by having too few staff of who fewer understood the challenges of the military truck market. Therefore, the department often had to rely on contracted consultants for market research. ${ }^{80}$

\section{b. Industry}

Industry's impact was experienced unevenly at multiple junctures throughout and before the MSVS project was initiated. In replacing the MLVWs in the Chrétien and Martin eras, it is recognized that complaints from domestic industry on the proposed sole-source options

\footnotetext{
${ }^{77}$ Canada. Department of National Defence. 2013-2014 Report on Plans and Priorities; Canada. Department of National Defence. 2015-2016 Report on Plans and Priorities.

${ }^{78}$ Subject Matter Expert \#2, Telephone interview with the Author, October 5, 2016.

${ }^{79}$ Senior government official, Telephone interview with the Author, December 8, 2016.

${ }^{80}$ Ibid.
} 
influenced enough cabinet ministers to defeat the attempt twice, thus setting back a replacement until after the 2005-2006 federal election. With the advent of the MSVS project in 2006, the splitting of the truck purchases into separate MilCOTS and SMP versions, plus the shelters, there was an uneven application of industrial pressure. The MilCOTS especially received criticism from Canadian industry. Soon after Navistar was declared the winner in 2009, domestic defence industry officials and unions voiced opposition to Navistar's selection, as the U.S. firm planned to build the militarized commercial trucks at its Illinois plan despite having already laid off an estimated 1,000 employees at its Chatham, Ontario truck plant. Having seen two-plus years of major sole source projects coming off U.S. assembly lines (e.g. CC-130Js, CC-177s, Chinook helicopters), Canadian defence industry associations voiced annoyance at being left out of advanced technology contract opportunities. The most they could expect from off-the-shelf deals from U.S. production lines, like the MilCOTS, were maintenance contracts. ${ }^{81}$ The shelters contract, in contrast, received little opposition likely on the grounds that it went to Ottawa-based DEW Engineering - the sole bidder.

The SMP was structured as an open competition and only began attracting noticeable industry opposition when the RFP was cancelled in July 2012, at literally the last minute. Industry officials at the time told the Canadian Press that the cancellation reflected "complete mismanagement" and "astounding incompetence" on the part of government. ${ }^{82}$ The most poignant opposition to the SMP, however, came after the contract was awarded in July 2015. Oshkosh Defense Canada, the only other bidder in the final competition aside from Mack Defense, filed a complaint in January 2016 with the Canadian International Trade Tribunal

\footnotetext{
${ }^{81}$ McDougall, "Army shrinks, downgrades truck fleet", 5; Pugliese, David, "Anger erupts over army truck purchase", The Leader-Post, January 26, 2009, B4.

${ }^{82}$ The Canadian Press. "Military truck purchase cancelled due to cost concerns," CBC News.
} 
(CITT), alleging that PWGSC had "ignored information in its bid, failed to follow the evaluation provisions within the RFP, improperly conducted the evaluation and failed to conduct a proper debriefing." 83 Oshkosh hoped that its bid would be re-evaluated and that the company would be found to have scored higher than Mack Defense, that and receive a CITT recommendation that the SMP contract be cancelled and awarded to them. Five months later the CITT did find in favour of Oshkosh, recommending that PWGSC re-evaluate the company's bid and a technical re-evaluation of its truck at the Nevada Automotive Test Centre facilities. ${ }^{84}$

The Tribunal found PWGSC had failed to keep "adequate records of the evaluation process" and that the original technical tests of Oshkosh's trucks in 2014 "were not properly conducted". However, the CITT opposed the idea of cancelling the contract with Mack Defense should a new re-evaluation determine that Oshkosh had the higher rating score. The CITT's reasons were two-fold: First, by mid-2016 some ten months worth of work had already been completed by Mack on the production of the new trucks. Second, there was no way for the CITT to know how well Oshkosh's trucks would have performed if the original physical tests had been carried out properly. Instead, the CITT recommended that the PWGSC compensate Oshkosh for the profits it would have received had it been awarded the contract in 2015. If a physical reevaluation were not possible, CITT recommended that PWGSC negotiate a compensation package with Oshkosh. ${ }^{85}$ As of 2017 there remains no update as to how PWGSC will proceed on this matter.

\footnotetext{
${ }^{83}$ Oshkosh Defense Canada Inc. v. Department of Public Works and Government Services, 1.

${ }^{84}$ Ibid., 52.

${ }^{85}$ Ibid., 50, 52, 54; Swick, Brenda C. "Review of Significant Canadian Federal Government Contracting Cases in 2016." The National Law Review, January 12, 2017.
} 


\section{c. Alliances and War}

Canada's alliances indirectly impacted the SMP project in one crucial area: the uptick in global military truck sales to meet the demands of U.S. and NATO campaigns in Iraq and Afghanistan. The purchasing of the trucks, illustrated perhaps as early as 2003-2004 when the U.S. Army indicated to its northern counterpart that it was buying 83,000 logistics trucks, created a classic supply and demand scenario. The solicitation of input from industry into the draft RFP in 2009 indicated that the original budget set in 2006 was not sufficient to meet the going market cost of the type of SMP the army desired.

Of course, the changed market circumstances between 2006 and 2009 reflected the desire of Canada's allies to acquire trucks capable of performing in harsh terrain and against IEDs. The CAF's own experiences in Afghanistan during this same period directly influenced the army's thinking on what it wanted in the SMP, chiefly, a heavier truck than the original two-and-a-half ton MLVWs and more armour. These specification changes led to a 40 percent increase in the project's cost, from $\$ 400$ million to $\$ 725$ million (not including the trailers and five years of inservice support). To make up for this shortfall, DND and the Canadian Army redirected funds from the LVM project to the SMP which triggered the cancellation of the RFP in July 2012 and added an 18-month delay to the project.

\section{Bringing It All Together}

In Atkinson's and Nossal's study of the 1980 CF-18 purchase, they concluded that the success of that project in both delivering a complex platform on time and on budget was due to the political executive's establishment of constraints around the bureaucracy. In clearly defining decisions on 
the jets' role, fleet size, and budget, for example, the three departments at the centre for Canadian defence procurement - DND and the CAF, PWGSC, and IC - and their officials could not use ambiguity on these matters as a way to advance their own personal and organizational parochial interests. In contrast, the MSVS-SMP project suffered from both a lack of clarity on roles and scope, and the absence of governance structure, the sum total of which led to bargaining games among DND and PWGSC, but also within DND and the army.

Because the project's envisioned role was never quite defined when it was announced in June 2006, the experiences of the army in Afghanistan (particularly in dealing with road-side bombs) and the eventual acquisition of large C-17 strategic lift aircraft meant that the early $\$ 430$ million estimated budget was insufficient for what the army felt it needed as a replacement for the three decade-old MLVWs. To quote one insider, "When overseas, [the] CAF didn't know what they needed as [the] situation unravelled quickly. ${ }^{\prime 86}$ Of course, planners were also constrained as they could not specify one particular truck as this would have also led to a failed procurement. ${ }^{87}$ And the SMP, because there were no stipulations on going with a proven, off-theshelf design (like that used in the MilCOTS buy), lacked basic contours on its specifications, a position that was undermined by the lack of engagement with industry before the requirements were released. ${ }^{88}$ Consequently, 'wish-list' thinking among army and DND planners ensued. As stated in the analysis above, the SMP project was "apparently pulled forward before all the necessary work was done to shape it. ${ }^{" 89}$ The growth in costs owing to the increase in requirements, coming as they did at the expense of a future truck program, handicapped the

\footnotetext{
${ }^{86}$ Confidential source, Telephone interview with the Author, January 23, 2017.

${ }^{87}$ Confidential source, Telephone interview with the Author, January 14, 2017.

${ }^{88}$ Confidential source, Telephone interview with the Author, October 11, 2016.

${ }^{89}$ Confidential source, Telephone interview with the Author, December 8, 2016.
} 
number of trucks the government could purchase. Therefore, when the SMP budget was raised and capped at $\$ 725$ million (using money from the Logistics Vehicle Modernization budget) to purchase 1,500 SMPs this figure did not match the CAF's own estimates for what the military needed to meet its own demand in personnel growth. The result was a shortfall of $650 \mathrm{SMP}$ trucks.

Unlike the CF-18 purchase, the Harper government's failure to apply an overarching governance structure between senior bureaucrats and their departments further accentuated delays. This situation led to the involved departments and the army to pursue their own organizational interests over the course of 2006-2012. The cancellation of the RFP in 2012, largely because of poor communication between DND, PWGSC, and the TBS over the SMP's budget added 18 months on the project and cost millions in project office expenses and inflationinflicted depreciation of the project budget. This poor communication was not necessarily benign but rather, as one defence procurement expert noted, the result of a longstanding challenge by DND and CAF officials in trying to understand how other government agencies read their documents: "DND and CAF talk to each other [and] are not prepared for questions" from TBS or PWGSC. ${ }^{90}$ Hence, without forewarning, "putting money somewhere else makes TBS nervous". 91 Another senior official was more blunt: problems were as much the result of "personalities and regulations" than anything. People in DND wanted to acquire a necessary military capability while those in PWGSC and TBS wanted a competition and an adherence to established project dollars, respectively. ${ }^{92}$ In contrast to the SMP, larger procurement projects, like the CF-18 purchase from 1980 to the recently completed Halifax-class Modernization/Frigate Life

\footnotetext{
${ }^{90}$ Subject Matter Expert \#1, Telephone interview with the Author, September 28, 2016.

${ }^{91}$ Confidential source, Telephone interview with the Author, January 18, 2017.

${ }^{92}$ Senior government official, Telephone interview with the Author, December 8, 2016.
} 
Extension (see Chapter Six), featured formalized decision-making structures involving representatives from senior positions across all involved departments and even industry (in the case of the latter). Such governance models allowed for problems to be resolved and for information to be communicated at regular intervals. The absence of such structures, in combination with a vague policy framework in the form of the 2008 Canada First Defence Strategy or even the June 2006 Conservative procurement announcement, meant there was little in the way of clear guidance that all departments and their officials could point to for direction and justification of their choices. Within an undefined project, competing organizational interests simply filled the void.

Of course, not all problems with the MSVS-SMP were the result of political-executivefuelled inter-departmental bickering. For one, that IC and the MSVS project office were each understaffed led to time lags in decision-making, process and evaluation. The lack of understanding of the global truck manufacturing market by IC contributed to a poor appreciation of what requirements industry was capable of meeting and at what cost early in the project. As well, exogenous independent variables were at play. The role of domestic industry in advocating for participation in the bidding proved to be a challenge to a smooth procurement process, something that the MSVS's predecessor shared with other projects across much of Canadian defence procurement. The original 2003-2004 attempt to acquire MLWV replacements was partly brought down by complaints from industry to government. Similar domestic industrial pressure was also involved in sidelining the Fixed-Wing Search and Rescue project (see Chapter Five) ${ }^{93}$ Likewise, the influence of ensuring industrial participation helped drive PWGSC's

\footnotetext{
${ }^{93}$ Pugliese, David. "Start Over on Canadian Forces Fixed Wing Search and Rescue, Report Suggests." Ottawa Citizen, February 12, 2010.
} 
desire to have not only a competition but to even go with four separate contracts that overly complicated decision-making on the MSVS. One official referred to the four contracts under the MSVS umbrella as a "dumb idea" as it made "DND operate as systems engineers". ${ }^{94}$ Afghanistan, as noted above, shaped the CA's views on increasing the size and weight of the trucks.

Canada is not alone in experiencing problems in acquiring trucks for its army. Australia's A \$7 billion Project Land 121-'Overlander’ program aims to replace 7,000 trucks of various types that were acquired by the Australian Army between 1959 and 1994. Land 121 was identified as a needed capability in the early-1990s. Like the MSVS, there are multiple components, or 'Phases', to the project. Phase 3B, the SMP equivalent which has encountered multiple delays since its inception, is designed to acquire 2,500 protected and unprotected trucks with some 3,000 specialized kits capable of being mounted on the back. The project was supposed to deliver its final trucks in 2016 after receiving approval in 2007. But Phase 3B had to be restarted again in 2013 and now the final delivery date is 2023; Rheinmetall's Australian subsidiary is the supplier. A key problem in that project was that Australian Department of Defense underestimated the complexity of the project, "with insufficient testing and poor communication of assessed risk". Therefore, Australia's DOD had to continually refine the requirements of the trucks in order to meet the project's budget. ${ }^{95}$

\footnotetext{
${ }^{94}$ Confidential source, Telephone interview with the Author, December 8, 2016.

${ }^{95}$ Andrew Davies, "Keep on Truckin", ASPI: The Strategist (30 June 2015). accessed February 20, 2017 : https://www.aspistrategist.org.au/keep-on-truckin/; Shaun Connors, "First batch of Overlander trucks delivered to ADF”, IHS Jane's Defence Weekly, 14 April 2016. accessed 21 February 2017:

http://www.janes.com/article/59476/first-batch-of-overlander-trucks-delivered-to-adf; DID Staff, "Overlander is On! Australia's A \$ 3+ Bn Vehicle Program”, Defense Industry Daily, 6 October 2015. accessed 21 February 2017: https://www.defenseindustrydaily.com/overlander-is-on-australia-issues-a-3bn-rft-01628/
} 
It should be recalled that this is not the first CAF truck program to go awry in recent years. The Light Utility Vehicle Wheeled (LUVW) project emerged out of an attempt to replace the army's Iltis jeeps. The light weight, soft 'skin' (i.e. thin metal shell), Iltis had been acquired in the 1980s. Itself a controversial purchase - bought from Bombardier at four times the per unit cost over its German competitor - the Iltis quickly experienced rust-out after its introduction and by 1989 the CAF was running out of spare parts as Bombardier shut down its production line once DND's order was complete. After a series of starts and stops the LUVW was given a 'green light' in 1997. Like the MSVS, the LUVW project involved both a military off-the-shelf and standard military pattern component. By the time a contract was inked in 2002 the entire project had been delayed by five years due to domestic pressure from British Columbia-based Western Star, who convinced the Defence Minister at the time to alter the statement of requirements to allow them to bid. In the interim, the Iltis reached its point of being "economically non-viable" and was deployed to Afghanistan were its lack of armour made it exceptionally vulnerable to IEDs and ambushes. ${ }^{96}$

The experiences of these truck projects indicate that when it comes to modern defence procurement few MCPs can really be understood as ostensibly 'simple'. Military equipment in the twenty-first century is exceeding complex. In the case of the SMP, the Canadian Army sought a truck that could withstand roadside bombs; transport a multitude of trailers designed to operate as kitchens, dentistry offices, and medical facilities; and traverse some of the harshest topographies on earth. The trucks also need to be capable of being transported on two types of RCAF aircraft and serve as the backbone of the army for two to three decades. Still, the SMP

\footnotetext{
${ }^{96}$ Nossal, Charlie Foxtrot: Fixing Defence Procurement in Canada, 44-54; Williams, Reinventing Canadian Defence Procurement, 9-10.
} 
experience also shows that technical complexity is not the only barrier to a timely, cost-effective acquisition. Canada's trifurcated procurement model, with its three departments (and the military), each operating according to its own statutory mandate, can accentuate delays and cost controls when political executive constraints are either ambiguous or lacking. The introduction of a new, expanded governance model like that used with the CF-18 purchase and the Halifaxclass Modernization/Frigate Life Extension, by the Conservative government in the 2014 Defence Procurement Strategy, is in attempt to incorporate such best practice approaches across the entire defence procurement program. As of now it remains to be seen if it is successful in bridging constraint to the bureaus.

Finally, the MSVS experience highlights the problems that can arise because of the disconnect between a global procurement market and lengthy procurement timelines. In a five to ten-year procurement process the marketplace can shift a lot. ${ }^{97}$ In short, what the MSVS demonstrates is that sometimes, the "simplest projects are the hardest to get moving." 98 The absence of decision-making structures and a clear understanding of what role the trucks would fulfill led to internal tensions between DND, PWGSC, and, to some extent, IC. Tensions were also evident within DND, as the army struggled to define its requirements around what exactly it wanted in the SMP. In this sense, the political executive can help explain why delays emerged with the SMP after its approval in June 2006. The project was thought to not be thoroughly vetted when it was announced by the Harper government as one its Big Four procurement acquisitions. That being said, the impact of the Afghanistan war and the changing nature of trucks in contemporary conflict mixed with a globalized, ever-evolving truck industry market

\footnotetext{
${ }^{97}$ Confidential source, Telephone interview with the Author, December 8, 2016.

${ }^{98}$ Confidential source, Telephone interview with the Author, September 27, 2016.
} 
made making plans and decisions much more complicated and thus contributed additionally to delays. 


\section{Chapter 5 - Fixed-Wing Search and Rescue Aircraft}

\section{Introduction}

Unique among Canada's defence commitments, the National Search-and-Rescue program (SAR) is a multi-agency effort shared primarily between the Department of National Defence, the Canadian Armed Forces, and the Canadian Coast Guard (CCG). ${ }^{1}$ DND, which has been the lead agency since 1947, has primary responsibility for aeronautical SAR and for coordinating operations with the CCG, who handle maritime SAR. Search-and-rescue coordination is achieved through three Joint Rescue Coordination Centres (JRCCs), located in Halifax, Nova Scotia; Trenton, Ontario; and Victoria, British Columbia. Each JRCC is allotted a section of what the military terms the SAR 'Area of Responsibility'. ${ }^{2}$ Encompassing three oceans, 18 million square kilometres of "sparsely settled and austere terrain" and the world's longest coastline, the Royal Canadian Air Force (RCAF) is tasked with ensuring an effective aeronautical SAR response. ${ }^{3}$ The JRCCs respond annually to an average 9,000 SAR incidents, of which 1,000 require an aeronautical response. ${ }^{4}$

In meeting its responsibilities under the National SAR program, DND and the RCAF have relied upon a mix of fixed-wing and rotary-wing (i.e. helicopters) fleets. Fixed-wing SAR (FWSAR) aircraft are used for the "rapid search, location, and airborne deployment" of searchand-rescue technicians ('SAR Techs') and equipment. Helicopters are deployed in recovery or

\footnotetext{
${ }^{1}$ Sloan, Something Has to Give: Why Delays Are the New Reality of Canada's Defence Procurement Strategy, 25.

${ }^{2}$ The provinces are responsible for search-and-rescue on land. The exception are national parks which are a federal responsibility. See: Canada. National Defence and the Canadian Armed Forces. Search and Rescue Posture Review 2013 (Ottawa: 2013).

${ }^{3} \mathrm{Ibid}$.

${ }^{4}$ Canada. National Defence and the Canadian Armed Forces. Chief Review Services. Evaluation of the DND/CAF Contribution to the National SAR Program (Ottawa: 2015), 6.
} 
rescue. $^{5}$ The rotary-wing fleet comprises CH-149 'Cormorant' and CH-146 'Griffin' helicopters purchased in the 1990s; these aircraft are stationed at CFBs Gander, Halifax, Trenton, and Comox. In contrast to the relatively newer helicopter fleets, the RCAF has relied upon an aging FWSAR fleet made up of six CC-115 twin-engine 'Buffalos', purchased in 1967, and ten fourengine CC-130 H-model 'Hercules' (C-130H), acquired between 1964 and 1967. These aircraft have been fulfilling SAR duties since the early 1970s. The Buffalos are based exclusively at CFB Comox while the C-130Hs are stationed at CFBs Greenwood, Trenton, and Winnipeg. An additional fleet of four smaller CC-138 'Twin Otters', are based out of Yellowknife and are tasked with both military transport and SAR duties in the Arctic. The Twin Otters have been in air force service since $1970 .^{6}$

The age and 'wear and tear' on the Buffalos and C-130Hs led to DND identifying the need for their replacement in November 2002. The FWSAR project was officially approved at cabinet in 2004 with a planned budget of $\$ 1.3$ billion for fifteen new aircraft. However, a solesource attempt to buy the C-27J 'Spartan', built by Italian firm Alenia, failed to get cabinet support. Singled out by the Harper Conservatives in their 2006 campaign platform and again in their 2008 Canada First Defence Strategy (CFDS), concerns over possible 'rigged' requirements in favour of the C-27J saw the FWSAR project mired in the options analysis stage until 2009 when the acquisition process was halted pending an arms-length independent review of the Statement of Requirements (SOR) by the National Research Council (NRC). A new SOR was

\footnotetext{
${ }^{5}$ Canada. National Defence and the Canadian Armed Forces. Chief Review Services. Evaluation of the DND/CAF Contribution, 14.

${ }^{6}$ Byers, Michael and Stewart Webb, Search and Rescue: The Case for a Made-in-Canada Fixed-Wing Search and Rescue Fleet (Ottawa: Rideau Institute/Canadian Centre for Policy Alternatives, 2012), 6-7, 11, 20.; Canada. National Defence and the Canadian Armed Forces. CC-138 Twin Otter, October 12, 2016. Accessed online May 16, 2017: http://www.rcaf-arc.forces.gc.ca/en/aircraft-current/cc-138.page.
} 
drawn up and the FWSAR entered the project definition stage in March 2012, a process that continued until March 2016 when the RFP closed. Finally, in December 2016, fourteen years after being identified as a priority project, the Justin Trudeau Liberal government awarded a \$1.55 billion contract for sixteen C-295W made by European firm Airbus Defence and Space, was awarded from among three bidders. ${ }^{7}$ This fourteen year delay between project identification and implementation has led to the FWSAR project being characterized by the press as "the most tortuous and long-delayed military procurement project in recent memory". ${ }^{8}$ By the time that a contract was awarded, there had been four chiefs of defence staff (CDS), seven ministers of national defence, and four prime ministers. ${ }^{9}$

Delays in getting the FWSAR project implemented negatively impacted the defence budget as aging aircraft consumed a greater share of the CAF's SAR budget. Between 2008 and 2012, the per-hour operating costs of the Buffalos and C-130Hs grew 57 percent and 22 percent respectively due the poor availability of spare parts, maintenance costs, and foreign currency fluctuation. ${ }^{10}$ These costs have totalled, on average, $\$ 40$ million per year since $2004 .{ }^{11}$ Keeping the Buffalos and $\mathrm{C}-130 \mathrm{Hs}$ in service has pushed these aircraft past their estimated life expectancy of 2015 and 2017 , into at least $2020 .^{12}$ The ability of the C-130H fleet to be available for responding to SAR incidents depreciated to the point where a 2009 DND audit determined

\footnotetext{
${ }^{7}$ Canada. National Defence and the Canadian Armed Forces, Fixed-Wing Search and Rescue Replacement Project, April 13, 2017. Accessed online May 16, 2017: http://www.forces.gc.ca/en/business-equipment/fixed-wingsnr.page; Perry, 2015 Status Report on Major Defence Equipment Procurements, 30-31.

${ }^{8}$ Den Tandt, Michael. “\$3.8B plan to buy search-and-rescue planes to go ahead.” Ottawa Citizen, May 29, 2012, A4.

${ }^{9}$ Confidential Source, Telephone interview with the Author, January 5, 2017.

${ }^{10}$ Canada. National Defence and the Canadian Armed Forces. Chief Review Services: Evaluation of the DND/CAF Contribution to the National SAR Program. Ottawa: 2015, 30.

${ }^{11}$ Canada. Department of National Defence. Chief Review Services. Audit of Fixed Wing Search and Rescue (FWSAR) Project. Ottawa: 2009, iv.

${ }^{12}$ Canada. National Defence and the Canadian Armed Forces. Chief Review Services: Evaluation of the DND/CAF Contribution to the National SAR Program. Ottawa: 2015, 11.
} 
that the entire fleet would have to be on standby in order to respond to incidents. ${ }^{13}$ Delays have seen a decline in the availability of pilot training hours as aircraft spend more time in maintenance and/or are placed on stand-by in order to meet SAR readiness requirements. ${ }^{14}$ More embarrassingly though, have been reports of RCAF personnel scouring a museum piece C-130H for spare parts, or switching propeller blades from one Buffalo to another due to a lack of spares. ${ }^{15}$ Table 5 below provides an overview of the key process milestones in the FWSAR project. The original dates established for advancing the project through the procurement process are compared to when they were actually achieved, or are planned to be achieved.

\begin{tabular}{|l|c|c|c|}
\hline \multicolumn{4}{|c|}{ Table 5 - FWSAR Project Milestones } \\
\hline \multicolumn{1}{|c|}{ Stage } & Original Date & $\mathbf{2 0 0 9}$ & Revised Date \\
\hline Project Identification & November 15, 2002 & $\checkmark$ & $\checkmark$ \\
\hline $\begin{array}{l}\text { Options Analysis } \\
\text { Complete }\end{array}$ & December 2003 & $\checkmark$ & - \\
\hline Project Definition (PPA) & October 2006 & Fall 2010 & March 2015 \\
\hline \multicolumn{1}{|c|}{ RFP Released } & March 2005 & - & March 2015 \\
\hline Implementation (EPA) & March 2008 & Fall 2011 & December 2016 \\
\hline \multicolumn{1}{|c|}{ First Delivery } & March 2011 & Spring 2015 & 2019 \\
\hline Final Delivery & March 2013 & Spring 2017 & 2022 \\
\hline Project Close-Out & September 2013 & Spring 2019 & 2023 \\
\hline
\end{tabular}

\footnotetext{
${ }^{13}$ Canada. National Defence and the Canadian Armed Forces. Chief Review Services: Audit of Fixed Wing Search and Rescue (FWSAR) Project. Ottawa: 2009, 4.

${ }^{14}$ Canada. National Defence and the Canadian Armed Forces. Chief Review Services: Evaluation of the DND/CAF Contribution to the National SAR Program. Ottawa: 2015, 13.

15 "Rescue aircraft inadequate." Times Colonist, September 20, 2014, A14.

${ }^{16}$ Dates come from a combination of the following sources: Canada. Department of National Defence, 2006-2007 Report on Plans and Priorities. Ottawa: 2006, 36; Canada. Treasury Board of Canada Secretariat. ARCHIVED National Defence - 2009-10 Departmental Performance Report. Accessed online July 14, 2017: http://www.tbssct.gc.ca/dpr-rmr/2009-2010/inst/dnd/st-ts03-eng.asp\#fwsar-amf; Canada. National Defence and the Canadian Armed Forces. 2017-18 Departmental Plan. "Status report on transformational and major Crown projects." Accessed online July 14, 2017: http://www.forces.gc.ca/en/about-reports-pubs-report-plan-priorities/2017-statusreport-on-transformational-and-major-crown-projects.page\#p8; Perry, 2015 Status Report, 31.
} 


\section{Political Executive Decisions}

\section{a. The Early Years (2002-2005)}

The first political executive decision pertaining to the FWSAR project occurred shortly after it was identified as a procurement priority by DND in November 2002. Then Liberal defence minister, John McCallum, attempted to bring forward a Memorandum to Cabinet (MC) seeking policy endorsement on an FWSAR purchase. However, McCallum encountered resistance from his cabinet colleagues who were being lobbied by Bombardier to open the contract up, and also from PWGSC and IC opposition. ${ }^{17}$

The FWSAR would not experience political executive involvement until Paul Martin replaced Jean Chrétien as prime minister in December 2003. As noted in Chapter Three, Martin wanted to distinguish himself from Chrétien through defence and foreign policy. Unlike his predecessor, who showed scant interest in military affairs, Martin vowed to "get the troops the equipment they need" ${ }^{18}$ However, in assessing what needed to be funded in anticipation of his government's first budget in March 2004, Martin ordered a freeze on all federal Major Crown Project (MCP) spending, during his first few months in office. ${ }^{19}$

The freeze was short-lived and had no discernable impact on the project since money had not been allotted. That all changed with the arrival of the 2004 budget on March $23^{\text {rd }}$. That budget marked the first time the political executive had supported and approved of the FWSAR

\footnotetext{
${ }^{17}$ Confidential source, Telephone interview with the Auhtor, January 5, 2017.

${ }^{18}$ Den Tandt, Michael. "Military's fast-track buying plan put on hold.” The Globe and Mail, November 16, 2005 , p. A5.

${ }^{19}$ Blanchfield, Mike. "Hercules, Buffalo could fly into history: Military makes case for \$200M program to replace ancient search, rescue aircraft." The Ottawa Citizen, February 10, 2004, p. A1.
} 
project. Labelled as a "major priority" for the CAF, the budget stated that planned deliveries for fifteen aircraft with search-and-rescue sensors, simulation and training supports, at a price of $\$ 1.3$ billion, would happen "later in the decade". ${ }^{20}$ With executive endorsement in hand, DND moved quickly, approving the setting up of a FWSAR project office three days later. ${ }^{21}$

Martin and his minister of national defence, Bill Graham, personally pushed for an accelerated acquisition of the FWSAR, even if it eventually meant not going to an open competition. ${ }^{22}$ Martin had made it clear that the FWSAR project was "open enough to allow any company an opportunity to participate, if it can" [author's emphasis]. ${ }^{23}$ The 2004 budget reflected this need for a speedy purchase by providing "non-budgetary resources" in the form of a $\$ 1.3$ billion loan to DND to cover the purchase cost of the aircraft but not the in-service support; the twenty year maintenance contract was to be made at a future date ${ }^{24}$ In not allotting the money up front for the project as part of DND's budget, the FWSAR project office focused on completing an options analysis and identifying a platform for an Advance Contract Award Notice (ACAN) purchase; by moving the FWSAR along these lines the defence minister, Bill Graham, was able to bring a MC before cabinet faster than would have been possible had the project followed the standard pathway of moving into the project definition stage following options analysis. With a planned contract award for 2005 , the first $\$ 300$ million out of the $\$ 1.3$ billion loan was to be made available that year with the remainder paid out to a successful bidder

\footnotetext{
${ }^{20}$ Canada. Department of Finance Canada. The Budget Plan 2004, 194.

${ }^{21}$ Canaada. National Defence and the Canadian Armed Forces. Chief Review Services: Audit of Fixed Wing Search and Rescue (FWSAR) Project (2009), 1; Canada. National Defence and the Canadian Armed Forces. 2004-2005 Report on Plans and Priorities, 27.

${ }^{22}$ Dawson, Anne. "Ottawa ready to open purse to buy new ships, helicopters: Total military spending package worth up to \$8B.” Edmonton Journal, April 13, 2004, A1.

${ }^{23}$ Den Tandt, Michael. "Ottawa considers aircraft purchase; \$12-billion military contract could bypass bid process." The Globe and Mail, November 11, 2005, A1.

${ }^{24}$ Williams, Reinventing Canadian Defence Procurement: A View from the Inside, 27; The aircraft numbers and price were later spelled out in DND's 2004-2005 Report on Plans and Priorities, p. 27.
} 
in similar increments over each succeeding year. ${ }^{25}$ Under this structure, the government planned to accept deliveries of new FSWAR aircraft "within 12 to 18 months" from the date of the March 2004 budget - an ambitious target. ${ }^{26}$

The need for fast-tracking the purchase came with the recognition of the heavy procurement shopping list the Martin Liberals had in front of them. Acquiring the FWSAR sooner would help address concerns about grid-lock in the procurement process and possible "displacing [of] other planned capital investments" like the Mobile Gun System (later scrapped by the Harper Conservatives), the Maritime Helicopter Project, and the Joint Support Ships, (discussed in Chapter Three). ${ }^{27}$ Naturally, a speedy purchase was also necessary because of the aging state of the Buffalos and C-130Hs. These aircraft had entered their fourth decade of service and were becoming costly to maintain. The CAF indicated to Martin officials that buying a new FWSAR aircraft addressed one of their "top three acquisition needs", and recommended that a Request for Proposals (RFP) be "released by March 31, 2005 with the intent of replacing the current SAR aircraft as soon as possible". ${ }^{28}$

The next political executive involvement occurred less than a year later, on February 23, 2005 when the second and last Martin budget was unveiled. No longer seeking to just procure fifteen aircraft to replace the Buffalos and Hercules, the Martin government made the decision to also replace the four Twin Otters based out of Yellowknife, by folding that project into the

\footnotetext{
${ }^{25}$ Canada. National Defence and the Canadian Armed Forces. 2006-2007 Report on Plans and Priorities, 36-37; Blanchfield, Mike. "No income tax for soldiers in danger zones: New search-and-rescue planes top tiny list of new defence expenditures." The Ottawa Citizen, March 24, 2004, A4.

${ }^{26}$ Canada. Department of Finance Canada. The Budget Plan 2004, 194.

${ }^{27}$ Ibid.; Pugliese, David. "Two solitudes: The defence community is deeply divided over how our cash-strapped military should face the future. Scrap the navy or air force, and beef up the army?" The Ottawa Citizen, October 16, 2004, A7.

${ }^{28}$ Canada. National Defence and the Canadian Armed Forces. 2004-2005 Report on Plans and Priorities, 27.
} 
FWSAR. ${ }^{29}$ The reason for the expanded program was entirely political: the Martin government had begun focusing on Arctic sovereignty issues, a growing political concern especially during a time of dispute with Denmark over Hans Island, and amid wider public discussions on the impact of climate change in the region. The year 2004 had marked the return of the CAF to the Arctic en masse for Operational Narwhal, their largest military exercise in the region since the end of the Cold War. ${ }^{30}$ The Narwhal operations, which continued to 2007 before being renamed Nanook under the Harper Conservatives, coincided with the prime minister Martin's Speech from the Throne in October 2004, when he laid out a plan for Canada to develop a "northern strategy" focused on sovereignty, security, and the environment. ${ }^{31}$ The exact cost of the Twin Otter replacement was never spelled out in the 2005 budget; instead the government lumped the replacements under the phrase "utility aircraft". ${ }^{32}$

Following the February 2005 budget, the FWSAR, Twin Otter included, were endorsed as acquisitions in the Martin government's new defence policy, the Defence Policy Statement (DPS), released on April 19, 2005. When released, the DPS included the FWSAR in its planned "aerospace capabilities" acquisitions for the CAF. ${ }^{33}$ With the objective of improving capabilities

\footnotetext{
${ }^{29}$ Canada. Department of Finance Canada. The Budget Plan 2005, 220; Canada. National Defence and the Canadian Armed Forces. 2006-2007 Report on Plans and Priorities, 36-37.

${ }^{30}$ Huebert, Rob. Canada and the Changing International Arctic: At the Crossroads of Cooperation and Conflict (Montreal: Institute for Research on Public Policy, 2008), 23; Shadwick, Martin. "Volte-Face or False Hope?" Canadian Military Journal (Spring, 2005), 72-73.

${ }^{31}$ Tracy, Nicholas. Two-Edged Sword: The Navy as an Instrument of Canadian Foreign Policy (Montreal-Kingston: McGill-Queen's University Press, 2014), 293; Canada. Privy Council Office, Speech from the Throne to Open the First Session of the 38th Parliament of Canada (2004). Accessed online June 5, 2017: http://www.pcobcp.gc.ca/index.asp?lang=eng\&page=information\&sub=publications\&doc=aarchives/sft-ddt/2004_2-eng.htm.

${ }^{32}$ Canada. Department of Finance Canada. The Budget Plan 2005, 205.

${ }^{33}$ Canada. National Defence and the Canadian Armed Forces. Defence Policy Statement, 2005, 14.
} 
in the Arctic, the DPS stated that the Twin Otter fleet would be retired in favour of "a more modern aircraft" with consideration given to basing the FWSAR in the region. ${ }^{34}$

The first defence policy since the 1994 White Paper on Defence had the effect of slowing down the FWSAR procurement process, as Air Command waited to see what the government's policy direction would be before proposing a final SOR. ${ }^{35} \mathrm{Up}$ to that point, concerns over the SOR being in favour of the C-27J saw the defence minister's office order a rewrite of the SOR four times over the period of 2004-2005. Officials in Graham's office voiced their concerns to the CAF that the project not be seen politically as a sole-source buy; they stressed the need for a SOR that allowed for a competition. ${ }^{36}$ The new ADM (Mat), Dan Ross, argued against an open competition. ${ }^{37}$ The ADM (Mat) was supported by Air Command and other defence bureaucrats who "made a formidable, compelling argument" for the C-27J ${ }^{38}$ However, the back-and-forth over the SOR saw the FWSAR project miss the budget 2004 deadline of having a RFP issued by March 31, 2005. Efforts by Graham to get the project before cabinet in June 2005 were unsuccessful before the parliamentary summer recess - a delay of two months. ${ }^{39}$

Eventually, political officials came around to a sole-source acquisition. They were motivated in supporting this move because of the Martin government's huge defence budget increase announced in the 2005 budget, and the presence of a new, popular CDS, General Rick

\footnotetext{
${ }^{34}$ Canada. National Defence and the Canadian Armed Forces. Defence Policy Statement, 2005, 20.

${ }^{35}$ Wattie, Chris. "Competition heats up for Forces planes." National Post, April 7, 2005, A7.

${ }^{36}$ Wattie, Chris. "Air force expansion hobbled by red tape: military sources: Bureaucratic, political concerns slow \$1.3B program." National Post, September 1, 2005, A13.

${ }^{37}$ Confidential Source, Telephone interview with the Author, January 5, 2017.

${ }^{38}$ Ibid.

${ }^{39}$ Blanchfield, Mike. "Air force gives firm's sales pitch short shrift." The Ottawa Citizen, June 6, 2005, A1; Wattie, Chris. "Air force plans to replace fleet: Cheaper to buy new aircraft than to maintain some older planes." National Post, August 31, 2005, A12.
} 
Hillier. Politically, Graham's office saw a chance to capitalize on this changed environment with a sole source bid. ${ }^{40}$ With the support of CAF brass and the "tacit approval" of the prime minister and defence minister, the FWSAR was combined with three other major air force projects Chinook helicopters, medium logistics trucks, tactical airlift and strategic airlift - into a large omnibus plan or "four pack", and brought before the Cabinet Operations Committee as an information note in November 2005; it was rejected. ${ }^{41}$ Former ADM (Mat), Alan Williams, has argued that the strategic and tactical airlift were not part of any internal DND procurement planning at the time, but were still advanced as procurement projects alongside the FWSAR because of the personal interests of the defence minister and CDS. This explained their announcement in the DPS. ${ }^{42}$

As had happened when McCallum tried to generate support for the FWSAR, there was much cabinet opposition to the omnibus procurement package proposal in November 2005. In short, the "sole source nature spooked ministers". ${ }^{43}$ Notably, it was the fear of lost offsets that generated the most opposition to the plan. Montreal-based Bombardier, the only large-scale airplane manufacturer in Canada, communicated to the Prime Minister's Office (PMO) that they would build the FWSAR in Toronto if given the opportunity to bid. This pitch "created substantial backroom pressure on the prime minister to have at least some of the new aircraft built in Canada". Toronto area MP and immigration minister, Joe Volpe, was especially strong on advocating for a competition. ${ }^{44}$ Public works minister Scott Brison and industry minister

\footnotetext{
${ }^{40}$ Confidential Source, Telephone interview with the Author, January 5, 2017.

${ }^{41}$ Wattie, Chris. "Lobbying, politicking delay planes for air force." National Post, November 16, 2005, A1.

${ }^{42}$ Williams, Reinventing Canadian Defence Procurement: A View from the Inside, 32.

${ }^{43}$ Confidential Source, Telephone interview with the Author, January 5, 2017.

${ }^{44}$ Den Tandt, Michael. "Ottawa considers aircraft purchase; \$12-billion military contract could bypass bid process." The Globe and Mail, November 11, 2005,A1.
} 
David Emerson similarly opposed the procurement plan, based on the advice of their respective departments who were against DND by-passing the open-tendering process. ${ }^{45}$ In the end, cabinet ministers deemed the proposal "too politically risky" so close to an impending election, with both Bombardier and Airbus lobbying hard for competitive bidding. ${ }^{46}$ Media leaks on the omnibus plan in the days leading up to the cabinet meeting did little to generate support in the political executive, as angered senior officials in the Martin PMO distanced the government from the proposal immediately following news of its leak. ${ }^{47}$

Had it received approval at the Cabinet Operations Committee that fall, the proposal would have gone before full cabinet a week later. Even after the rejection, the project was to be brought before cabinet again; but it was to be after the election that was called later that month, in which the Martin government was eventually defeated as a result of a non-confidence motion. Graham had wanted to have another shot at getting the deal approved but the election disrupted that effort; telling reporters at the time, "We don't make major procurements during elections". ${ }^{48}$

\section{b. The Early Harper Years (2006-2009)}

During their first two years in power, the Stephen Harper-led Conservatives assigned little priority to the FWSAR project not forcing movement on the file until 2008. Similar to their Liberal opponents, during the 2005-2006 election campaign the Harper Conservatives pledged to

\footnotetext{
${ }^{45}$ Blanchfield, Mike. "\$12 billion in new aircraft needed now: defence chief." The Ottawa Citizen, November 12 , 2005), A3.

${ }^{46}$ Den Tandt, Michael. "Military's fast-track buying plan put on hold." The Globe and Mail, November 16, 2005, A5; Wattie, Chris. "Lobbying, politicking delay planes for air force." National Post, November 16, 2005, A1.

${ }^{47}$ Den Tandt, "Military's fast-track buying plan put on hold," 2005.

${ }^{48}$ Wattie, "Lobbying, politicking delay planes for air force," 2005, A1.; "Election would stall new planes." The Edmonton Journal, November 16, 2005, A5.
} 
purchase an unknown number of FWSAR aircraft. ${ }^{49}$ While the Conservatives made a great priority of defence and the CAF on the campaign trail, their actual policy commitments were fairly thin. ${ }^{50}$ Like the Martin Liberals, when it came to the FWSAR project, the only statement was in relation to the Arctic (also a popular election theme for the Conservatives) and the stationing of FWSAR aircraft in Yellowknife. ${ }^{51}$

When the Harper government finally came to power in February 2006 they came with their own defence policy plan, one that moved away from the Martin government's military transformation vision and the associated initiatives encapsulated in the Defence Policy Statement (discussed in Chapter Three). Titled 'Canada First' and authored by the new defence minister, Gordon O'Connor, the Conservatives envisioned a CAF that kept to the traditional three armed services structure in place since before unification in $1968 .{ }^{52}$ On the matter of new equipment for the RCAF the Canada First plan emphasized turning CFB Trenton into a logistics hub for the entire $\mathrm{CAF}$ with the air force purchasing strategic and tactical airlift, and medium-heavy lift helicopters. However, before implementing their own defence procurement plans the Harper government needed to assess the outstanding commitments made by the Martin government. In April 2006 O'Connor, as had his predecessor Bill Graham done before, ordered a freeze on all defence MCPs. With the DPS unofficially dead, existing defence MCPs lacked clear policy

\footnotetext{
${ }^{49}$ Blanchfield, Mike. "Big Issues: Defence and Foreign Affairs - the four main parties have differing views about defending Canada." Edmonton Journal, January 12, 2006, A4.

${ }^{50}$ Nossal, Kim Richard. "Defense Policy and the Atmospherics of Canada-U.S. Relations: The Case of the Harper Conservatives." American Review of Canadian Studies 37, No. 1 (2007).

${ }^{51}$ Sloan, Something Has to Give: Why Delays Are the New Reality of Canada's Defence Procurement Strategy, 26.

${ }^{52}$ Confidential Source, Telephone interview with the Author, January 22, 2017.
} 
direction in the first six months of 2006 resulting in little movement on any files initiated under the Martin Liberals. ${ }^{53}$

In June 2006 the culmination of these actions led to the first significant political executive FWSAR decision of the Harper government: the sidelining of the project in favour of $\$ 17$ billion in expenditures for four C-17 strategic airlift aircraft, seventeen C-130 'J' model tactical aircraft (C-130J), the three Joint Support Ships and two fleets of Medium Support Vehicle System trucks for Land Force Command. ${ }^{54}$ No longer a priority, the FWSAR project office was disbanded the same month due to what DND referred to as "unresolved procurement strategy issues" and the need "to work on other priority projects". ${ }^{55}$ In explaining why the Harper government deviated from the FWSAR, despite the $\$ 1.3$ billion loan for the project having been approved in the 2004 budget and the fact that a SOR had been drawn up, Sloan argues that the ramp-up of the combat mission in Afghanistan at the same time as the Conservatives took power in February 2006, "had the effect of pushing aside procurement projects not related to the Afghan operation". 56

In contrast to the military's SAR capabilities, in early 2006 the CAF lacked the equipment necessary to sustain and maintain the Afghanistan deployment. The June 2006 transport plane and helicopter purchases, and later a \$1.1 billion acquisition of Leopard II tanks,

\footnotetext{
${ }^{53}$ Pugliese, David. "Tories freeze all spending on new gear for military.” The Ottawa Citizen, April 15, 2006, A1. ${ }^{54}$ Hillier, A Soldier First.

${ }^{55}$ Canada. National Defence and the Canadian Armed Forces. Chief Review Services: Audit of Fixed Wing Search and Rescue (FWSAR) Project, 2009, ii, 1.

${ }^{56}$ Ibid., p. 25.
} 
helped address an immediate operational need. This 'priority' or 'focus' was certainly shared within senior government circles. According to one official:

No one in 2006-2007 was asking where the FWSAR [was]. We already had a capability for fixed-wing and we needed to replace it but it didn't make the cut. With Afghanistan, there were no existing capabilities and so [they] needed a priority. ${ }^{57}$

The low priority given to the FWSAR project was reflected in DND's own annual Report on Plans and Priorities (RPP) submissions to the Treasury Board Secretariat (TBS). Among the many functions of the RPPs is updating central bureaucrats on the status of the department's MCPs. Despite being a 'high priority' designation in the Martin-era RPPs the FWSAR was notably absent from the 2007 and 2008 RPPs.

Of course, the ability of Air Command to keep the aging Buffalos and C-130Hs airborne played a role in relegating the FWSAR project to the proverbial backburner. Despite the aged aircraft Air Command's fixed-wing SAR assets had an impressive incident response rate when tasked by the JRCCs. A 2015 DND audit found that maintenance issues prevented the air force's air assets from responding to just one (1) percent of incidents. ${ }^{58}$ The less sophisticated nature of the Buffalos and C-130Hs helped in this regard. These aircraft were designed for rapid deployment meaning that their key capabilities were speed, range, and cargo capacity and not costly software and sensor systems that would require replacement or upgrading. ${ }^{59}$ During the rare times the Buffalos or C-130Hs were not available, the air force was able to rely on its other

\footnotetext{
${ }^{57}$ Senior Government Official, Interview with the Author, September 23, 2016.

${ }^{58}$ Canada. National Defence and the Canadian Armed Forces. Chief Review Services: Evaluation of the DND/CAF Contribution to the National SAR Program. Ottawa: 2015, 9.

${ }^{59}$ Ibid., 14.
} 
non-SAR aircraft, namely the $\mathrm{CP}-140$ patrol planes or the new $\mathrm{C}-130 \mathrm{~J}$ transports, to respond to an incident. ${ }^{60}$ Moreover, in 2007, the fast sole-source purchase of the C-17s freed up newer C130 'E' model (C-130E) Hercules, already in Air Command's inventory to replace the older, cost intensive C-130Hs. ${ }^{61}$ An additional factor was that the widespread, global use of the Buffalos provided the air force with enough spare parts to keep the aircraft flyable. ${ }^{62}$

The next political executive involvement in the FWASR project occurred in May 2008, when the Conservative government released its defence policy, the Canada First Defence Strategy (CFDS). The CFDS took two years to compose, a process that involved numerous consultations with TBS and the Department of Finance. The Prime Minister's Office initially resisted making the CFDS public, preferring to adhere to public statements made by Harper and his second defence minister, Peter MacKay. ${ }^{63}$ The CFDS did reiterate "the importance of the FWSAR replacement" and increased the FWSAR project budget from $\$ 1.3$ billion to $\$ 1.55$ billion, with an equal amount allotted for a long-term maintenance contract. The project office, disbanded in 2006, was re-established. ${ }^{64}$ The Conservatives also increased the number of FWSAR aircraft to be purchased, from fifteen to seventeen and identified the project as one of the CAF's "core equipment fleets". ${ }^{65}$ Surprisingly, considering that the project had been in existence since 2004, the Harper government framed the FWSAR project as part of their $\$ 20$

\footnotetext{
${ }^{60}$ Ibid, p. 9.

${ }^{61}$ Lt. Gen. J.S. Lucas, then-Chief of the Air Staff, Testimony before the Standing House Committee on National Defence, February 15, 2007.

${ }^{62}$ Rear Admiral (ret'd.), Patrick Finn, Assistant Deputy Minister (Material), Testimony before the Standing House Committee on National Defence, May 5, 2016; Pugliese, David. "Defence plan outlines long-range strategy." The Gazette, December 4, 2006, A13; LeBlanc, Daniel. "Air force may abandon \$3-billion plan." The Globe and Mail, February 6, 2007, A6.

${ }^{63}$ Blanchfield, Mike. "Military strategy for cabinet's eyes only." The Ottawa Citizen, May 15, 2008, A4.

${ }^{64}$ Pugliese, David. "DND wants new Italian SAR planes." The Ottawa Citizen, December 18, 2008, A6; Canada. National Defence and the Canadian Armed Forces. Chief Review Services: Audit of Fixed Wing Search and Rescue (FWSAR) Project, 2009, iv, 1.

${ }^{65}$ Canada. National Defence and the Canadian Armed Forces. Canada First Defence Strategy, $2008,4$.
} 
billion in "New Major Fleet Replacements", placing the project alongside the Maritime Patrol Aircraft (a replacement for the CP-140 'Aurora'), sixty-five "next-generation fighter aircraft", and fifteen warships (now the Canadian Surface Combatant project). ${ }^{66}$ The CFDS established 2015 as the date in which the new search-and-rescue aircraft were to be delivered. ${ }^{67}$ Notably missing from the CFDS was a Twin Otter replacement; it resurfaced only in 2017 as a MCP under the Trudeau government's defence policy. ${ }^{68}$

Mimicking language from the Martin years, defence minister MacKay described the FWSAR as "a top priority". Behind the scenes, MacKay attempted a repeat of Bill Graham's earlier efforts to sole-source the acquisition ${ }^{69}$ In late 2008 MacKay made it clear that he intended to bring a proposal before cabinet in early 2009 for the sole-source purchase of the C27J (the Italian designed C-27J would be built in the United States). ${ }^{70}$ MacKay's goal was "to procure early this year". ${ }^{71}$ However, as had happened with the Liberals, trouble brewed in 2008 once it became clear that the Conservatives were interested in sole sourcing the C-27J. Allegations of preferential treatment to Alenia for the C-27J, over Airbus's C-295 and Bombardier, "got all the politicians torqued up". ${ }^{72}$ MacKay was "incensed" that industry lobbyists were telling the public that domestic aerospace manufacturers would not see any economic benefits with a sole-source $\mathrm{C}-27 \mathrm{~J}$ contract. ${ }^{73}$ The timing of the allegations could not

\footnotetext{
${ }^{66}$ Canada. National Defence and the Canadian Armed Forces. Canada First Defence Strategy, 2008, 13.

${ }^{67}$ Canada. National Defence and the Canadian Armed Forces. Canada First Defence Strategy, 2008, 17.

${ }^{68}$ Canada. National Defence and the Canadian Armed Forces. Strong, Secure, Engaged: Canada's Defence Policy (Ottawa: 2017), 39.

${ }^{69}$ Pugliese, David. "DND urged to buy rescue aircraft." The Ottawa Citizen, April 6, 2010, A1; Senior Government Official, Interview with the Author, September 23, 2016.

${ }^{70}$ Pugliese, David. "DND wants new Italian SAR planes." The Ottawa Citizen, December 18, 2008, A6.

${ }^{71}$ Chase, Steven. "B.C. firm chasing \$3-billion deal to modernize rescue plane." The Globe and Mail, January 6, 2009, A4.

${ }^{72}$ Senior Government Official, Interview with the Author, September 23, 2016.

${ }^{73}$ Blanchfield, Mike. “Air force chief defends \$3B plan for new aircraft.” The Ottawa Citizen, March 28, 2009, A5.
} 
have been worse as a global recession had taken effect and the Harper government was spending billions in stimulus funding to boost the economy.

The sting of accusations of allegedly missed economic development opportunities clearly struck a chord with the political executive. Amid the Harper government's 2009 deficit spending defence minister Peter MacKay took finance minister Jim Flaherty to Afghanistan to convince him of the need to support the CFDS's procurement spending plans. Given the changed global economic circumstances, MacKay also framed the government's defence procurement plans as "good for the country's economic health". ${ }^{74}$ Despite complaints from Bombardier and Airbus, not everyone at the political executive level saw it (the air force's favouring of the C-27J) as a problem. There was a view within the defence minister's office that the RCAF had "written reasonable specs". As far as ministerial staff were concerned, if Canadian industry had made an actual FWSAR aircraft the government would advocate for its purchase, "We would buy it, we're political people", stated one official. ${ }^{75}$

The planned acquisition approach led to reports of tension between MacKay and his cabinet counterparts in PWGSC, Rona Ambrose, and IC, Tony Clement. ${ }^{76}$ The three ministers were unable to come to agreement on the procurement strategy for the FWSAR, keeping it from going before cabinet as a sole-source. This impasse led to the three ministers agreeing to place the SOR under the review of the NRC in October 2009. ${ }^{77}$ The NRC review, completed over fall 2009 and winter 2010, became a major source of delay; it forced the FWSAR back to the options

\footnotetext{
${ }_{74}^{74}$ Blanchfield, Mike. "\$60B in defence spending rolls on despite recession.” Edmonton Journal, May 28, 2009, A4.

${ }^{75}$ Confidential Source, Telephone interview with the Author, January 17, 2017.

${ }^{76}$ Blanchfield, "\$60B in defence spending rolls on despite recession," A4; Pugliese, David. "\$3B Buffalo retirement project back on government radar." Edmonton Journal, January 27, 2010, A6.

${ }^{77}$ Confidential Source, Telephone interview with the Author, January 23, 2017; Senior Government Official \#1, Interview with the Author, September 23, 2016.
} 
analysis phase before returning to project definition again in March $2012 .^{78}$ The FWSAR was delayed over two years before the deadlock was finally resolved. ${ }^{79}$

\section{c. The Later Harper Years (2010-2015)}

Political executive decision-making on the FWSAR in the 2010-2015 period of the Harper government was dominated by the fallout of the NRC report which was blunt in its assessment of the FWSAR's SOR. The Council's expert panel found the SOR to be "over-constrained to the extent that very few compliant solutions are possible" ${ }^{80}$ Or, to put it another way, the NRC report gave credence to the criticism that the air force had written the requirements with the C$27 \mathrm{~J}$ in mind. The Council found the SOR to be too specific on speed and range while the requirements on basing, crewing, and standby posture were merely a repeat of the "status quo". It was no surprise when the NRC recommended that the SOR be rewritten with an emphasis on capabilities rather than specific platform requirements (i.e. a particular aircraft). The Council felt this allowed for more bidders and flexible acquisition options. ${ }^{81}$

The NRC review also addressed a number of other inter-related concerns. For instance, the SOR assumed that one aircraft with two engines could meet Canada's search-and-rescue needs, "effectively preclude[ing] serious consideration of a multiple-fleet solution" similar to the current mix of Buffalos and C-130Hs. ${ }^{82}$ Likewise, the Council challenged the notion that the FWSAR capability could only be provided by the military. Considering Air Command's use of

\footnotetext{
${ }^{78}$ Canada. National Defence and the Canadian Armed Forces. 2012-2013 Status on Major Crown Projects.

${ }^{79}$ Confidential Source, Telephone interview with the Author, January 12, 2017.

${ }^{80}$ Canada. National Research Council Canada. Review of the Statement of Operational Requirement for the Fixed Wing Search and Rescue Aircraft. Report No. CR-FRL-2010-0025 (2010), 5-6.

${ }^{81}$ Ibid.

${ }^{82}$ Ibid., 9.
} 
civilian aircraft under the CASARA program, the NRC recommended that the government look at "contracted support for elements such as aircraft, aircrew, and maintenance functions". Such alterative service delivery, they argued, "may lead to a lower cost solution and a more effective response" ${ }^{83}$ In fact, in July 2011 MacKay mused publicly about pursuing such a recommendation and privatizing National Defence's search-and-rescue capabilities. A meeting was held with industry representatives to discuss the option but the combination of RCAF opposition and public backlash saw a quick retreat. ${ }^{84}$

Finally, the Council took issue with the lack of justification and consensus on the actual number of FWSAR aircraft required, and with future basing considerations. The SOR, last updated in 2006, called for a minimum of fifteen aircraft but the CFDS stipulated seventeen and DND's own Director for Air Force Readiness asked for nineteen. With respect to basing options, the report recommended the requirement be cut for using traditional FWSAR squadrons in CFBs Comox, Winnipeg, Trenton, and Greenwood, as they "do not represent the best option for SAR response". The Council suggested that basing FWSAR aircraft in CFB Gander, Newfoundland, instead of Greenwood, Nova Scotia, reduced "the distance to cover $90 \%$ of the historical SAR incidents examined in the study from $653 \mathrm{~nm}$ [nautical miles] to $533 \mathrm{~nm}$ ”. Having FWSAR aircraft based out of CFB Gander required one less fuel stop for mid-North Atlantic SAR incidents. $^{85}$

\footnotetext{
${ }^{83}$ Ibid., 10.

${ }^{84}$ Subject Matter Expert \#1, Interview with the Author, October 5, 2016; Pugliese, David. "Tories eye privatizing search and rescue." Ottawa Citizen, July 21, 2011, A1; The Canadian Press. "Private planes could aid search and rescue work." The Hamilton Spectator, February 15, 2011, A8; "Canada looks for search planes." The Times \& Transcript, January 8, 2013, C3.

${ }^{85}$ Canada. National Research Council Canada. Review of the Statement of Operational Requirement for the Fixed Wing Search and Rescue Aircraft, 2010, 37-38.
} 
The next political executive involvement in the FWSAR occurred in January 2012 when it went before the Treasury Board. Treasury Board ministers approved an open competition procurement strategy for the FWSAR. In keeping with the NRC report, the SOR would be performance based with DND and the RCAF articulating their needs for fixed-wing capability, and industry coming up with the solution. A new project schedule established a time frame for the issue of a draft RFP in September 2012 followed by implementation in 2014. The project budget was revised to $\$ 3.8$ billion, of which half was set aside for in-service support. ${ }^{86}$ The Treasury Board decision also included the adoption of a new governance structure modeled on that used in the National Shipbuilding Procurement Strategy the previous year. Like the NSPS, the FWSAR Secretariat was headquartered in PWGSC which then became the lead department on the project; this allegedly became a source of friction between MacKay and Ambrose. ${ }^{87}$ The last discernable political executive decision impacting the FWSAR project was the 2015 federal election. The Conservative's decision to call a three month election period, the longest since the $19^{\text {th }}$ century, pushed back the RFP deadline from September 2015 to January $2016 .{ }^{88}$

\section{Exogenous Explanations}

\section{a. Defence Procurement Bureaucracy}

$D N D / C A F$ : From the defence bureaucracy perspective, the key factors cited as contributing to the delays in the FWSAR project were the air force's favouring of the Alenia C-27J as the aircraft of choice and the Air Command/DND's writing of the SOR to exclude other potential bidders. In the words of former ADM (Mat) Alan Williams, an "ideal SOR" should foster

\footnotetext{
${ }^{86}$ Den Tandt, "\$3.8B plan to buy search-and-rescue planes to go ahead", 2012, A4.

${ }^{87}$ Sloan, 26; "Our rescue plane embarrassment." National Post, May 3, 2013, A12.

${ }^{88}$ Brewster, Murray. "New planes high on Liberal agenda." Ottawa Citizen, December 16, 2015, A11.
} 
competition by "framing requirements in performance terms" by specifically stating what the aircraft should be able to do as opposed to stating "how exactly it has to be able to it" ${ }^{89}$ Between 2004 and 2010 Air Command relied more or less on a SOR that gave the appearance of a competitive process but in effect was written in a way that favoured the C-27J. During these years DND and the air force could not get agreement at the bureaucratic and ministerial level or with their counterparts in PWGSC and IC on the intended procurement approach.

For DND and the RCAF, federal search-and-rescue duties are considered a 'no-fail mission', meaning that the air force must be able to respond when Canadians' lives are in danger. ${ }^{90}$ While there is debate within the CAF as to whether the SAR role fits with the military's mandate, search-and-rescue remains one of the few very visible and important programs that the CAF undertakes. ${ }^{91}$ Within this context, DND and the CAF sought a replacement for its two aging fleets of fixed-wing aircraft in the early 2000s in order to ensure continued operational readiness for search-and-rescue duties. However, due to the deteriorating state of its C-130 transport fleet, air force planners sought an aircraft that could also undertake secondary transport duties. Like the JSS and the MSVS-SMP, the FWSAR project became an example of the longstanding practice of DND and the CAF of trying to get as much capability as possible from a new procurement purchase; this at least partially resulted from the multiple decades of interlude between the last acquisition purchases and the small numbers of equipment that are bought.

\footnotetext{
${ }^{89}$ Williams, Reinventing Canadian Defence Procurement: A View from the Inside, 2006, 39-40.

${ }^{90}$ Canada. National Defence and the Canadian Armed Forces. Search and Rescue Posture Review 2013.

${ }^{91}$ Confidential Source, Telephone interview with the Author, October 11, 2016.
} 
Hence, the primary motivation for opting for the C-27J in the options analysis stage in 2003 was to overcome the 'wear and tear' of not one but two types of aircraft. ${ }^{92}$ The Buffalos and C-130Hs of the SAR fleet needed to be replaced but so did the C-130Es and Hs of Air Command's transport fleet. In 2003 it was known within defence circles that the air force's C130s were the most heavily used "military C-130 aircraft in operation anywhere in the world". ${ }^{93}$ The state of the C-130 prompted the deputy minister of national defence in 2002 to recommend their replacement by 2010. Air Command's Buffalos were in no better condition; the first of several life extensions took place in December 2002 to keep the planes flying at least to $2010 .^{94}$ Subsequent extension projects allowed the Buffalos to keep in operating until 2019 when the first new replacement aircraft are scheduled to arrive - over 50 years after they entered service.

During the Chrétien and Martin governments, defence bureaucrats and CAF officers pushed hard for a FWSAR replacement project, setting multiple "high priority meetings" with political staff to generate momentum and support. ${ }^{95}$ One particular example occurred in May 2002, when then defence minister John McCallum was told by deputy minister Margaret Bloodworth that the FWSAR was the "top capital priority for the Canadian Armed Forces". ${ }^{96} \mathrm{~A}$ year later, in September 2003, then CDS General Ray Henault publicly emphasised his argument when he declared that the FWSAR was the "top equipment priority for the military". ${ }^{97}$

\footnotetext{
${ }^{92}$ Subject Matter Expert \#2, Confidential interview with the Author, October 5, 2016.

${ }^{93}$ Blanchfield, Mike. "Hercules, Buffalo could fly into history: Military makes case for \$200M program to replace ancient search, rescue aircraft." The Ottawa Citizen, February 10, 2004, A1.

${ }^{94}$ Blanchfield, "Hercules, Buffalo could fly into history: Military makes case for $\$ 200 \mathrm{M}$ program to replace ancient search, rescue aircraft", 2004, p. A1.

${ }^{95}$ Confidential Source, Telephone interview with the Author, January 18, 2017.

${ }^{96}$ Confidential Source, Telephone interview with the Author, January 5, 2017.

${ }^{97}$ Pugliese, David. "DND should rewrite requirements for \$3B search aircraft project: NRC." The Ottawa Citizen March 17, 2010, A1.
} 
The air force's preference for the C-27J emerged out of a series of interoperability, financial and marketplace concerns. Air force planners sought an aircraft that was cheaper than the C-130 in both purchase and maintenance costs, but yet also equipped with the endurance and speed capabilities of a C-130, due to the vastness of the SAR Area of Responsibility. ${ }^{98}$ However, when Air Command officials searched the global marketplace they encountered few options to choose from. ${ }^{99}$ Bombardier, for instance, had produced popular commercial aircraft like the Dash-8 and Q400 but these planes did not have a back-end ramp incorporated into their designs - a 'must have' requirement for the parachuting SAR Techs. ${ }^{100}$ For financial reasons both DND and Air Command wanted to control costs by keeping the existing fixed-wing SAR bases in Nova Scotia, Ontario, Manitoba and British Columbia. ${ }^{101}$ This meant that any replacement required the C-130's capacity for long-range missions without refuelling. It also, as Sloan notes, ruled out flexible basing options (e.g. stationing aircraft in Yellowknife or Iqaluit) that could have opened the project up to more bidders. ${ }^{102}$ However, removing the older SAR C-130s and the Buffalos reduced maintenance costs borne out by having duplicate fleets, aging air frames and engines, and a lack of spare parts. Likewise, a C-27J purchase allowed for increased hangar capacity at CFBs because of its smaller size compared to the C-130. In the short to medium term, military officers and defence bureaucrats also thought that a dual-role FWSAR could free up

\footnotetext{
${ }^{98}$ Confidential Source, Telephone interview with the Author, January 5, 2017; Confidential Source, Telephone interview with the Author, January 12, 2017; Confidential Source, Telephone interview with the Author, January 14, 2017.

${ }^{99}$ Confidential Source, Telephone interview with the Author, January 12, 2017.

${ }^{100}$ Senior Government Official \#3, Telephone interview with the Author, September 25, 2016.

${ }^{101}$ Confidential Source, Telephone interview with the Author, January 12, 2017.

${ }^{102}$ Sloan, Something Has to Give, 26.
} 
some of the younger $\mathrm{C}-130 \mathrm{H}$ airframes acquired in the 1990s for tactical transport functions and away from their search-and-rescue standby role. ${ }^{103}$

Finally, in the C-27J the air force saw an aircraft with technical similarities to the C-130. Lockheed Martin, manufacturer of the C-130 family of aircraft, had partnered with Alenia on developing the C-27J. Both aircraft used the same engine manufacturer - Pratt \& Whitney Canada. ${ }^{104}$ They also had similar operating systems and, while the C-27J had two engines versus the C-130's four, the Italian aircraft was capable of carrying NATO standard cargo pallets and landing on short runways. In fact, the similarities between the two aircraft were so striking that in Canadian defence circles the C-27J was referred to as a "stubby' Herc" or "Baby Herc", owing to its smaller airframe. ${ }^{105}$ Notably, the traits the air force favoured in the C-27J were also the traits that made the C-27J the aircraft of choice (at least until 2012) for the U.S. Air Force's medium transport role. While not necessarily pertinent to a fixed-wing search-and-rescue aircraft these capabilities satisfied the transport requirements Air Command sought. ${ }^{106}$

Because of these factors it was alleged that the air force wrote the SOR in a way that it favoured the C-27J and excluded other possible contenders. The more benign explanation posited is that air force planners were hampered by a lack of clear departmental guidance on developing a SOR to begin with; ${ }^{107}$ an obstacle that DND's own auditor said was compounded

\footnotetext{
${ }^{103}$ Wattie, Chris. "Forces still waiting for new planes." National Post, February 21, 2005, A4.

${ }^{104}$ Confidential Source, Telephone interview with the Author, January 5, 2017.

${ }^{105}$ Confidential Source, Telephone interview with the Author, January 17, 2017.

${ }^{106}$ Senior Government Official \#1, Telephone interview with the Author, September 28, 2016; Byers, Michael. "Needed: A big yellow plane that can hang from the sky." National Post, March 13, 2012, A12.

${ }^{107}$ Canada. National Defence and the Canadian Armed Forces. Chief Review Services: Audit of Fixed Wing Search and Rescue (FWSAR) Project. 2009, v.
} 
by human resource pressures in the procurement field across DND, PWGSC, and IC. ${ }^{108}$ The FWSAR project management office was understaffed due to the increased demands on air force personnel to develop requirements for new tactical and strategic lift aircraft in 2005-2011. ${ }^{109}$ That it was shut down in 2006 to redirect personnel to other air force projects bears this it out. For these reasons the SOR was developed without a clear direction as to what the intended FWSAR platform was supposed capabilities-wise, a point affirmed by DND's own internal auditor, the Chief Review Services in 2009. ${ }^{110}$ The CRS estimated that there were 150 requirements in the FWSAR SOR designated as a 'essential' for which there "was no criteria established for the project office to determine which...should be selected as mandatory". ${ }^{111}$ Accordingly, in using the $\mathrm{C}-130$ as a benchmark, the absence of clearly ranked requirements and an overabundance of essential requirements meant that the SOR implicitly excluded non-C27J aircraft, like Airbus's C-295. ${ }^{112}$ For example, between 2004 and 2009, various iterations of the SORs excluded the C-295 because its cabin was fifteen centimetres shorter and its cruising speed twelve knots slower than what requirements specified, requirements that the C-27J met. ${ }^{113}$

However, a more critical view contends that DND and Air Command were suffering from "institutional inertia and no commitment to process" $" 114$; something one senior government official attributed to the air force simply overplaying its strength after a series of successful solesource aircraft acquisitions between 2006 and 2008. ${ }^{115}$ Air Command's unwillingness to

\footnotetext{
${ }^{108}$ Canada. National Defence and the Canadian Armed Forces. Chief Review Services: Audit of Fixed Wing Search and Rescue (FWSAR) Project. 2009, 12.

${ }^{109}$ Senior Government Official, Telephone interview with the Author, September 23, 2016.

${ }^{110}$ Confidential Source, Telephone interview with the Author, January 22, 2017.

${ }^{111}$ Canada. National Defence and the Canadian Armed Forces. Chief Review Services: Audit of Fixed Wing Search and Rescue (FWSAR) Project. 2009, 6.

112 Williams, Reinventing Procurement 39.

113 Byers and Webb, 8.

114 Confidential Source, Telephone interview with the Author, October 11, 2016.

115 Senior Government Official \#3, Telephone interview with the Author, September 25, 2016.
} 
compromise became a constraint on getting the project approved. ${ }^{116}$ Driven by a desire to "fast track' the FWSAR procurement, the CRS found air force planners to have understated the project's risk assessment. ${ }^{117}$ While DND and Air Command may have taken the view that their PWGSC and IC counterparts were operating as "bureaucrats trying to design airplanes", the fact was that both departments could not reach an agreement with DND on acceptable level of risk. Due to the political, legal, and economic concerns with a sole-source C-27J purchase based on a SOR written to rule out other aircraft, a move that came perilously close to violating the government's own Contracting Policy on requiring a competitive procurement process (without an invocation of one of the exceptions described in Chapter Two. ${ }^{118}$ ) Consequently, it became difficult to get the FWSAR project before cabinet. ${ }^{119}$

Air Command and DND tried at least twice to bring the C-27J tilted FWSAR project forward for cabinet approval; both times, in 2005 and 2008-09, they were unsuccessful because of ministerial and senior bureaucratic unease, within PWGSC and IC, on the sole source approach. Tellingly, even within DND there was (at times) opposition to sole sourcing the C-27J. Alan Williams, as ADM (Mat) from 1999 to 2005, refused to endorse the air force's C-27J plans on the grounds that it would raise project costs by twenty percent, lead to lost domestic industrial benefits, and leave unanswered questions as to the aircraft's suitability and capabilities. ${ }^{120} \mathrm{~A}$ change in senior bureaucratic and military leadership in 2005 led to a more united front within DND and the CAF on the FWSAR project. With Hillier in place as CDS along with a new ADM

\footnotetext{
${ }^{116}$ Confidential Source, Telephone interview with the Author, January 12, 2017.

${ }^{117}$ Canada. National Defence and the Canadian Armed Forces. Chief Review Services: Audit of Fixed Wing Search and Rescue (FWSAR) Project. 2009, 12.

${ }^{118}$ Confidential Source, Telephone interview with the Author, January 12, 2017; Confidential Source, Telephone interview with the Author, January 22, 2017.

${ }^{119}$ Senior Government Official \#2 (ret'd.), Interview with the Author, September 26, 2016.

${ }^{120}$ Former Assistant Deputy Minister (Material), Alan Williams, Interview with the Author, September 5, 2016.
} 
(Mat) and DM, the defence bureaucracy in fall 2005 made its first serious attempt to by-pass an open competition process. CDS Hillier's $\$ 12$ billion 'omnibus' plan merged fifteen FWSAR planes - said to be C-27Js - with the sixteen new C-130J transport planes, fifteen Chinook medium-heavy lift helicopters, and four new planes to replace the Twin Otters. ${ }^{121}$ From the military and DND's perspective the logic of this plan was straightforward: the RCAF knew what it wanted and the existing fleets were too old to keep operating (something which Hillier stressed in a cabinet briefing to Ministers in November 2005). ${ }^{122}$ Opposition from both PWGSC and IC senior bureaucrats and their ministers over the sole-source approach led to the plan's rejection. Had it been approved at cabinet the aircraft could have been delivered within 36 months with a project close-out in 60 months. ${ }^{123}$

Even after the Conservatives took power in 2006, the FWSAR remained officially a "[h]igh priority" for Air Command and DND. Internally though it was never clear whether the FWSAR was the "top project" for the defence bureaucracy; it was sharing the priority list with the F-35, the Canadian Surface Combatants, the Arctic Offshore/Patrol Ships, and upgraded Light Armoured Vehicles. ${ }^{124}$ With the air force, the FWAR was positioned as one of four 'must have' air force projects, alongside strategic and tactical airlift, the Chinook helicopters and, if possible, four new replacements for the Twin Otters. ${ }^{125}$ With the Harper Conservatives focused on advancing their June 2006 procurement announcement projects the FWSAR ceased being a

\footnotetext{
${ }^{121}$ Wattie, Chris. "Air force plans to replace fleet: Cheaper to buy new aircraft than to maintain older planes." National Post, August 31, 2005, A12; "Election would stall new planes." The Edmonton Journal, November 16, 2005 , A5.

${ }^{122}$ Blanchfield, Mike. "\$12 billion in new aircraft needed now: defence chief." The Ottawa Citizen, November 12, 2005, A3.

${ }^{123}$ Den Tandt, Michael. "Ottawa considers aircraft purchase; \$12-billion military contract could bypass bid process." The Globe and Mail, November 11, 2005, A1.

${ }^{124}$ Postmedia News. "Top DND procurement goal is for search-and-rescue.” Nanaimo Daily News, May 30, 2011, A9.

${ }^{125}$ Canada. National Defence and the Canadian Armed Forces. 2006-2007 Report on Plans and Priorities, 24, 46.
} 
government priority until the release of the CFDS in 2008; at this point the brunt of Afghanistanrelated equipment had been either purchased or had contracts issued. Some of this equipment, of course, like the C-17s and C-130Js, removed the sense of immediacy surrounding a FWSAR replacement, as older C-130 models were removed from service and replaced with existing air force C-130Hs (albeit, still twenty years old) as the new strategic and tactical aircraft entered service. ${ }^{126}$ Still, some senior CAF officers made efforts to reignite government support for the project during this period. In 2007 Lieutenant General Angus Watt, then commander of the air force, arranged meetings with defence minister MacKay to get the FWSAR before cabinet, but got nowhere. ${ }^{127}$ A second effort was also tried to fast track the purchase of the C-27Js. In early 2008, Watt attempted to bring a sole source FWSAR proposal before cabinet; particularly because while the $\mathrm{C}-130$ fleet may have gotten a reprieve, the Buffalos were running into serious maintenance issues with spare parts now coming from surplus Brazilian aircraft. ${ }^{128}$ A $\$ 75$ million upgrade in 2008 for the Buffalos replaced the engines, strengthened their airframes and landing gear, but a replacement was still deemed necessary by $2015 .{ }^{129}$ DND's stated goal was to have "this project proceed into its definition as soon as possible so it might be ready for approval in 2008", with aircraft deliveries pushed off for another year, to 2014-2015. ${ }^{130}$

However, the attempt to get the FWSAR before cabinet faltered, as the military's insistence at sticking with the SOR sustained "[f]ractured views" on the project between the defence bureaucrats on one side and PWGSC and IC on the other. The impact of this meant that

\footnotetext{
126 Subject Matter Expert \#1, Confidential interview with the Author, October 5, 2016; Confidential Source, Telephone interview with the Author, October 11, 2016.

${ }^{127}$ Confidential Source, Telephone interview with the Author, January 17, 2017.

${ }_{128}$ Brewster, Murray. “Old rescue planes won't be retired for several years.” The Daily Gleaner, April 14, 2008, A6.

129 The Canadian Press. "Flying Buffalos not extinct - yet." The Halifax Daily News, October 22, 2007, 9; Pugliese, "\$3B Buffalo retirement project back on government radar", 2010, A6.

${ }^{130}$ Canada. National Defence and the Canadian Armed Forces. 2008-2009 Report on Plans and Priorities, 58.
} 
the project went "in circles". ${ }^{131}$ Lack of agreement between the departments was explicitly demonstrated in the summer of 2009 at a DND-led 'information day' with interested bidders. With procurement representatives from PWGSC and IC also at the table, industry attendees described the event as a "disaster" when none of the bureaucrats from the three departments could provide answers on the number of FWSAR planes to be purchased, their software requirements, or a date when the planes would be purchased. ${ }^{132}$ This event fed into already strong industry opposition to the project's procurement approach and increasingly made the FWSAR politically unpalatable throughout 2008 and $2009 .{ }^{133}$ Eventually the culmination of these factors led to the National Research Council's involvement and the loss of DND's leadership on the file with the creation of the FWSAR Secretariat in February 2012 and PWGSC becoming the lead department.

In accordance with the NRC report, the SOR had to be rewritten by DND. ${ }^{134}$ Once the FWSAR was restarted in March 2012, DND postponed the RFP process for a year to allow for further consultations with industry. ${ }^{135}$ Following a PWGSC consultant's review of the project, DND had to further rewrite the RFP in 2013 to include a "Canadian In-Service Support Integrator" to "maximize the industrial benefits accruing to Canadian industry" from the longterm support monies. ${ }^{136}$

\footnotetext{
${ }^{131}$ Confidential Source, Telephone interview with the Author, January 22, 2017.

132 Pugliese, David. "DND should rewrite requirements for \$3B search aircraft project: NRC." The Ottawa Citizen March 17, 2010, A1.

${ }^{133}$ Pugliese, David. "Industry Canada, DND feud over how to spend \$3 billion; Canadian jobs at centre of spat." The Ottawa Citizen, March 26, 2009, A1.

${ }^{134}$ Pugliese, "DND should rewrite requirements for \$3B search aircraft project: NRC", 2010, A1.

${ }^{135}$ Canadian Press. "Replacement for 50-year-old air force search planes postponed." Prince George Citizen, March 9, 2012, 15.

136 Perry, David. 2015 Status Report on Major Defence Equipment Procurement. Calgary: Canadian Global Affairs Institute, 2015, 30 .
} 
PWGSC: The FWSAR project was characterised by bureaucratic infighting between IC and PWGSC, and DND. ${ }^{137}$ The inability to get agreement between the departments on a procurement strategy for the FWSAR impacted the project during the Martin government, in the fall of 2005, and again during the Harper government, in 2008-2009, following the release of the CFDS and the restart of the project. DND referred to these as "external delays in the endorsement of the procurement strategy". ${ }^{138}$

In the Martin and early Harper years PWGSC was concerned over the FWSAR project's requirements. According to one official, there was a feeling within PWGSC that not everything was "kosher" with the FWSAR's SOR, and this became a source of delays as PWGSC refused to support DND's approach to the project. ${ }^{139}$ DND's timelines were also thought to be "unrealistic". ${ }^{140}$ PWGSC's influence on pushing against the requirements influenced Treasury Board's decision to deny permission for DND to go with a sole-source contract because of the "narrow and exclusionary character of the specifications". ${ }^{141}$ The combination of IC's and PWGSC's concerns regarding DND's procurement approach caused all three departments' ministers to recommend the SOR be sent to the National Research Council for review in the fall of 2009. For PWGSC, the outcome of the Council's review led to the Harper government giving the department the leadership on the FWSAR, and the establishment of a secretariat housed within the department. None of these organizational changes diminished PWGSC's mistrust towards DND. In the summer and fall of 2013, PWGSC reached out to a consultant, Orbis Risk

\footnotetext{
${ }^{137}$ Blanchfield, "\$60B in defence spending rolls on despite recession”, 2009, A4.

${ }^{138}$ Canada. National Defence and the Canadian Armed Forces. Chief Review Services: Audit of Fixed Wing Search and Rescue (FWSAR) Project (2009), 5; See also: Perry, David. 2015 Status Report on Major Defence Equipment Procurement. Calgary: Canadian Global Affairs Institute, 2015, 30.

139 Senior Government Official \#2, Confidential interview with the Author, September 26, 2016.

140 Ibid.

${ }^{141}$ Byers, Michael. "Needed: A big yellow plane that can hang from the sky." National Post, March 13, 2012 , A12.
} 
Consulting Inc., to perform another independent review of the project in order to ensure that the SOR was not biased to a particular bidder and to determine if the project was achieving its offsets potential (of importance to IC). ${ }^{142}$ Orbis found that the project was not geared towards any particular aircraft and that the project required all bids to include a Canadian company in order to provide the in-service support maintenance contract in order "to maximize the industrial benefits". 143

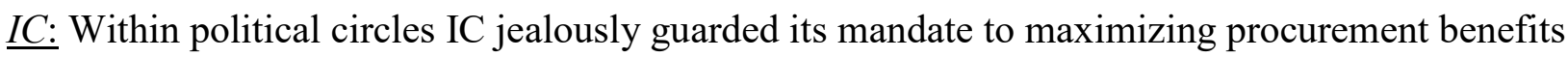
to Canadian firms. ${ }^{144}$ During the early Harper years, the sole-source purchases between 2006 and 2008 were viewed by IC as a mixed experience, as not all contractors were found to be meeting their IRB obligations of matching 100 percent of the value of the contract. ${ }^{145}$ By 2009 IC had become opposed to DND's sole-source plans for the FWSAR. As the department responsible for the government's domestic offsets regime, IC officials were under industry and labour pressure to ensure that more economic spinoffs occurred. IC pushed for an open competition on the FWSAR so that it would create "the maximum number of jobs within the country". ${ }^{146}$ Department officials favoured a competition and they had Bombardier in mind when they examined the SOR. ${ }^{147}$ IC made it clear to their DND counterparts that the FWSAR project was a "line in the sand" on what they felt was a procurement system that had become too oriented to the interests of DND and the CAF. From the IC perspective, the C-17, C-130J, and Chinook

\footnotetext{
${ }^{142}$ Canada. Public Services and Procurement Canada. Fixed-Wing Search and Rescue Aircraft Replacement Project - Independent Review of Evaluation Plans, Methods and Tools (2013).

143 Ibid.

${ }^{144}$ Confidential Source, Telephone interview with the Author, January 17, 2017.

${ }^{145}$ Ibid.

${ }^{146}$ Pugliese, David. "Industry Canada, DND feud over how to spend $\$ 3$ billion; Canadian jobs at centre of spat." The Ottawa Citizen, March 26, 2009, A1.

${ }^{147}$ Confidential Source, Telephone interview with the Author, January 12, 2017.
} 
projects had all come at the expense of strengthening Canada's own aerospace industry. ${ }^{148}$ In conjunction with PWGSC, IC officials helped defeat Hillier's sole source plan in 2005 and forced the SOR before the National Research Council for a review in 2009.

\section{b. Industry}

Lobbying and complaints from aerospace manufacturers were a consistent theme throughout the FWSAR project, and remain so today. In fact, at times media reports have described lobbying on the FWSAR as "ferocious". ${ }^{149}$ During the Chrétien and Martin phase of the project, industry pressure was largely driven by the fact that the project represented the first new major fixedwing military aircraft contract since the CF-18s were acquired in the early 1980s. In conjunction with this factor was the reality that less technologically sophisticated aircraft like the FWSAR were the only type of aircraft capable of being manufactured in Canada. The domestic defence industrial base had moved away from indigenous fighter aircraft manufacturing with the cancellation of the Avro 'Arrow' in 1959; this is turn was followed by the abandonment of building U.S. jets under licence once the last CF-5 'Tigers' were assembled in $1972 .{ }^{150}$ By the 1990s, Bombardier remained the only major Canadian firm capable of manufacturing aircraft. Unfortunately for the company its planes (like the Q400) were designed for commercial aviation purposes and not the military. ${ }^{151}$ Nevertheless, being the only major Canadian company left

\footnotetext{
${ }^{148}$ Pugliese, "Industry Canada, DND feud over how to spend \$3 billion; Canadian jobs at centre of spat", 2009, A1; Blanchfield, "Air force chief defends \$3B plan for new aircraft", 2009, A5.

149 Wattie, Chris. "Lobbying, politicking delay planes for air force." National Post, November 16, 2005, A1.

${ }^{150}$ Major Ray Stouffer. "Cold War Air Power Choices for the RCAF: Paul Hellyer and the Selection of the CF-5 Freedom Fighter." Canadian Military Journal (Autumn 2006): 63-74.

${ }^{151}$ The Canadian Encyclopedia. "Bombardier Inc." Accessed online June 8, 2017:

http://www.thecanadianencyclopedia.ca/en/article/bombardier-inc/.
} 
making airplanes meant that "FWSAR seemed to stumbled around [the] political factor of Bombardier" throughout the project's history. ${ }^{152}$

When the FWSAR project was first publicly announced by the Martin government in 2004, it immediately garnered the attention of both domestic and foreign manufacturers. According to the Ottawa Citizen at the time, the FWSAR was the "richest military deal" since the announcement of the Sea King replacement project. ${ }^{153}$ Initially, Bombardier lobbied both the Chrétien and Martin governments "heavily" with the intention of pressuring those governments to have DND alter the SOR to allow for the Dash-8 aircraft design to compete for the project despite the fact that the Dash-8 did not have a ramp for SAR Techs and cargo to parachute from, and was considered by Air Command to be "too small, too slow and ill-equipped". ${ }^{154}$ This lobbying "created delays at the bureaucratic and political level", as detailed above. ${ }^{155}$ Lacking the political and economic connections of Bombardier did not stop foreign firms Airbus and Alenia from lobbying, even though their targets were less often members of the political executive and more focused on senior officers and bureaucrats, respectively, in the air force and DND, and in PWGSC and IC. A good example is Airbus's 2005 public relations campaign; it pitched the C-295 as the most cost-effective option available, capable of delivering "lower purchase price and servicing costs". The C-295 could allegedly let the air force buy more aircraft and provide them with more basing options across the country. ${ }^{156}$ Airbus even flew test flights of the C-295 across the Arctic to highlight the capabilities of its aircraft - tests that were notably

\footnotetext{
152 Senior Government Official (ret'd.), Interview with the Author, September 25, 2016

${ }^{153}$ Blanchfield, Mike. “Air force gives firm's sales pitch short shrift.” The Ottawa Citizen, June 6, 2005, A1.

${ }^{154}$ Den Tandt, Michael. "Ottawa considers aircraft purchase; \$12-billion military contract could bypass bid process."The Globe and Mail, November 11, 2005, A1.

${ }^{155}$ Confidential Source, Interview with the Author, January 5, 2017.

156 Wattie, Chris. "Competition heats up for Forces planes." National Post, April 7, 2005, A7.
} 
boycotted by the RCAF. ${ }^{157}$ In contrast, and much to the consternation of Airbus, the RCAF had allowed Alenia to visit its four SAR bases with the C-27J on a cross-Canada public relations campaign in October 2003, thus giving credence to the view that military skewed the project towards the C-27J. ${ }^{158} \mathrm{CDS}$ Rick Hillier's omnibus plan to buy multiple fleets of aircraft in November 2005, led to intense political lobbying by Airbus, Bombardier, and Alenia. The former two companies went out of their way to convince Martin government officials that the CDS's plan was "rash and will cost far more than it should" without a competition. Industry officials went so far as to compare the sole-source attempt as a repeat of the Gomery sponsorship scandal. ${ }^{159}$

The influence of industry during the Harper era was no different than with Martin. Industry representatives were known to have called on the Prime Minister's Office to press the case for a competition. ${ }^{160}$ Driven by the perception of "cooked requirements" (specifications in favour of the C-27J), industry allegations of an 'unfair' procurement process dogged the FWSAR project throughout the Harper years. ${ }^{161}$ This situation was exacerbated during the Harper government's first three years in power, when major air force purchases - like the C-17s, C130Js, and Chinook helicopters - were acquired through UORs, much to the irritation of Canadian companies who felt left out of lucrative offsets benefits (even though they were benefiting from long-term maintenance contracts). ${ }^{162}$ The pressure from lobbyists got so intense that Air Command commander Lieutenant-General Angus Watt had to call a press conference

${ }^{157}$ Blanchfield, "Air force gives firm's sales pitch short shrift," A1.

${ }^{158}$ Ibid., A1.

${ }^{159}$ Den Tandt, "Ottawa considers aircraft purchase; \$12-billion military contract could bypass bid process," 2005, A1.

${ }^{160}$ Confidential Source, Interview with the Author, January 17, 2017.

${ }^{161}$ Senior Government Official \#2 (ret'd.), Confidential interview with the Author, September 26, 2016.

162 "Auditor general plans to review defence sole-source contracts." Prince George Citizen, November 28, 2007, 7. 
because, "We're getting beat up too much on fixed-wing SAR". ${ }^{163}$ When the FWSAR reemerged as a procurement priority in the 2008 CFDS, the Harper government's "mishandling of the file allowed competitors to successfully convince the public into believing that the Harper government had an agenda to sole-source the aircraft" at the expense of Canadian jobs and benefits. ${ }^{164}$

The "mishandling" was the Conservatives' repeat of the Liberals' mistake, in using a sole-source approach to move ahead with the purchase of the C-27J in 2009, they also saw resistance from Alenia's competitors Airbus and Bombardier. ${ }^{165}$ Bombardier, in particular, wanted the research and development dollars from the FWSAR project to modify its Q400 commercial design (to include a ramp) and operate it as a search-and-rescue model aircraft. ${ }^{166}$ The waters were further muddied when, in 2009, another domestic manufacturer, British Columbia-based Viking Air Ltd., entered the fray. Viking had purchased the design blueprints for the Buffalo and was publicly touting that it could build a modernized version of the RCAF's aging plane for 40 percent less than the C-27J. That Viking could apparently do its manufacturing in Canada only sweetened the prospect, but also constrained the political environment towards discussion of a C-27J purchase from Alenia. ${ }^{167}$ Fallout from the earlier air force sole-source contracts also brought organized labour into the opposition fold. The Canadian Autoworkers Union, which represented 3,300 aerospace workers in the Toronto area, lobbied hard against any C-27J purchase by citing how other air force procurements delivered "no work,

\footnotetext{
${ }^{163}$ Blanchfield, Mike. "Air force chief defends \$3B plan for new aircraft." The Ottawa Citizen, March 28, 2009 , A5.

${ }^{164}$ Confidential source, Interview with the Author, November 30, 2016.

${ }^{165}$ Pugliese, David. "DND wants new Italian SAR planes." The Ottawa Citizen, December 18, 2008 , A6.

${ }^{166}$ Confidential Source, Telephone interview with the Author, January 12, 2017.

${ }^{167}$ Chase, Steven. "B.C. firm chasing \$3-billion deal to modernize rescue plane." The Globe and Mail, January 6, 2009, A4; Pugliese, David. "Industry Canada, DND feud over how to spend $\$ 3$ billion; Canadian jobs at centre of spat." The Ottawa Citizen, March 26, 2009, A1.
} 
and no industrial benefits from the money spent so far." 168 The union went after the officials in DND and IC. ${ }^{169}$ Seeing an opening for a possible customer, DND and the RCAF also became the centre of attention for lobbying by Bell Helicopters and Boeing, builders of the V-22 'Osprey' tilt-rotor aircraft (could both fly like a plane and hover like a helicopter). However, the US\$70 million-per-aircraft price-tag - over three times the cost of a C-27J - removed the Osprey as a serious contender. ${ }^{170}$

It is worth noting that Alenia did not improve its position when in 2012 company officials stated that they would not service twenty-one C-27Js that had become mothballed due to Pentagon cuts to the U.S. Air Force. Alenia officials told a U.S. industry publication that it opposed the sale of the Pentagon C-27Js to another country over fears that the company would lose its market share. This position effectively sank a purchase opportunity for the Harper government which, despite the domestic opposition they were facing, had considered fast tracking the FWSAR project in 2012. ${ }^{171}$ Such a move would not have been out-of-the-ordinary for the Harper government; in 2011 DND orchestrated the purchase of nine VH-71 helicopters and 800,000 spare parts from the U.S., for $\$ 164$ million. The VH-71, which bore a resemblance to the RCAF's CH-149 Cormorant, had been intended for use as a Presidential helicopter; it was cut by President Obama due to cost overruns. The 2011 purchase was intended to provide the Cormorant with a long supply of spare parts, however the nine barely used helicopters maintained their airworthiness and have now been considered for replacing the aging Cormorant

\footnotetext{
168 Pugliese, "Industry Canada, DND feud over how to spend \$3 billion; Canadian jobs at centre of spat”, 2009, A1. 169 Ibid.

170 “Canada looks for search planes.” The Times \& Transcript, January 8, 2013, C3.

${ }^{171}$ Cited in Woods, Allan. "Hunt for rescue planes relaunched." Toronto Star, March 22, 2012 , A16.
} 
models. ${ }^{172}$ As for the U.S. Air Force C-27Js, they were eventually split between the U.S. Coast Guard and Special Operations Command. ${ }^{173}$

Industry pressure on the FWSAR was largely relieved with the NRC report in 2009-2010. The Council's critique and rejection of the original SOR validated concerns that the requirements were skewered towards the $\mathrm{C}-27 \mathrm{~J}$. The $\mathrm{NRC}$ report, which recommended moving the project to a capability-based SOR, used a computer data model based on historical operational patterns to make the case for a competitive process which allowed industry to come up with the solutions. Debate exists within NDHQ as to whether the government compromised too much in going with a competition but the NRC process and recommendations did bring an element of transparency to the FWSAR project, even if it took a contentious battle with multiple governments over a tenyear period, 2002-2012. ${ }^{174}$ Moreover, with the NRC report in hand it dawned on Harper government officials and those within the defence bureaucracy that "the perception of a competition mattered a lot". ${ }^{175}$ As of writing, the controversy surrounding the FWSAR project has not dissipated. Alenia, which lost out to Airbus when the contract was awarded in December 2016, has since challenged the SOR and the RFP process in both the Federal Court and the Canadian International Trade Tribunal (the latter has been unsuccessful) because DND was not forthright in the project's budget. ${ }^{176}$

\footnotetext{
172 Postmedia News. "RCAF's new search and rescue plan: refurbish the U.S. president's old helicopters." National Post, June 4, 2015.

${ }^{173}$ Hemmerdinger, Jon. "US Coast Guard to acquire USAF's remaining C-27J Spartans.” FlightGlobal.Com, January 6, 2014. Accessed online June 11, 2017: https://www.flightglobal.com/news/articles/us-coast-guard-toacquire-usafs-remaining-c-27j-spartans-394575/.

${ }_{174}$ Confidential Source, Interview with the Author, January 12, 2017.

175 Senior Government Official \#1 (ret'd.), Interview with the Author, September 23, 2016.

${ }^{176}$ Connolly, Amanda. "Trade tribunal investigating support contract for fixed-wing search and rescue." iPolitics. Accessed online March 27, 2017: http://ipolitics.ca/2017/03/27/trade-tribunal-investigating-support-contract-forfixed-wing-sr/.
} 


\section{c. Alliances and War}

Opinion remained divided on the role Canada's commitment to the Afghanistan war may have played as a source of delays with the FWSAR project. Some officials were adamant that there was absolutely no connection between the two, that delays were "not a preoccupation with the Afghan war". ${ }^{177}$ Others refer to it as a "100 percent accurate assessment". ${ }^{178}$ However, there is a nuanced case to be made that the war in southwest Asia did play a role in contributing to delays by simply taking up the "government's limited time". ${ }^{179}$ Within ADM (Mat) in Ottawa, there were a limited number of personnel to handle all the procurements, a "question of bandwidth." 180 And when it came to Afghanistan, there was "certainly an accelerated need to move forward with Army specific equipment and to deal with the specifics of the Afghan mission". 181

The 2005-2011 combat phase of the Canadian commitment in Afghanistan absorbed much of DND's and the Treasury Board Secretariat's capacity to move defence's MCPs through the procurement process. The primary aim, especially in the early years of the war, was to "surge to get the army what it need[ed] to deal with [operational] challenges". ${ }^{182}$ Projects like the M777 artillery pieces and Leopard II tanks ate up "time in Treasury Board and human resource capacity in DND", a situation not unlike that experienced by Canada's allies in London and

\footnotetext{
177 Senior Government Official, Interview with the Author, September 26, 2016; Confidential Source, Email interview with the Author, November 30, 2016; Senior Government Official \#1 (ret'd.), Interview with the Author, September 23, 2016.

${ }^{178}$ Confidential Source, Telephone interview with the Author, January 23, 2017; Confidential Source, Telephone interview with the Author, January 14, 2017.

${ }^{179}$ Confidential Source, Telephone interview with the Author, January 23, 2017.

${ }^{180}$ Subject Matter Expert \#1, Confidential interview with the Author, September 28, 2016.

${ }^{181}$ Senior Government Official \#1 (ret'd.), Interview with the Author, September 23, 2016.

182 Confidential Source, Telephone interview with the Author, January 27, 2017.
} 
Washington. ${ }^{183}$ The focus on meeting the needs of troops on the front meant turning to speedier, sole-sourced acquisitions, through the invocation of UORs exemptions under the government's Contracting Policy. ${ }^{184}$ In addressing this equipment 'crunch', the Harper government established an ad-hoc Afghanistan cabinet committee. Under these conditions the "Kandahar projects dominated" and non-war related procurement projects like the FWSAR, received less attention. Likewise, when the FWSAR project was initially conceived in 2002 it was to help alleviate Air Command maintenance costs and readiness concerns on the aging $\mathrm{C}-130 \mathrm{Hs}$ and $\mathrm{C}-130 \mathrm{E}$ tactical transport fleet. But the purchase of the newer ' $\mathrm{J}$ ' model C-130s and the larger C-17s relieved the pressure to wholesale replace the $\mathrm{C}-130 \mathrm{Hs}$, as the $\mathrm{C}-130 \mathrm{E}$ models were reassigned to the SAR role. ${ }^{185}$ However over time, the push by the political executive to get Afghanistan-related equipment, created a situation where bureaucrats, particularly in PWGSC and IC, grew tired of UOR justified purchases; such officials became less enthusiastic about sole-source acquisitions as time went on. ${ }^{186}$

Outside of process pressures and competing priorities, the purchasing of so many warrelated projects consumed a larger share of DND's capital budget than expected. ${ }^{187}$ A succession of multi-billion dollar "Afghan-centric projects" like the C-17s, C-130Js, and Chinooks, and the army’s \$650 million Leopard II tanks, designed to meet the CAF's logistics and operational demands placed tight constraints on defence procurement spending to the an extent that there

\footnotetext{
183 Ibid.

${ }^{184}$ Confidential Source, Telephone interview with the Author, January 14, 2017.

185 Subject Matter Expert \#1, Confidential interview with the Author, October 5, 2016; Confidential Source, Telephone interview with the Author, January 22, 2017.

186 Ibid.

${ }^{187}$ Canadian Press. "Proposals drawn up to replace aging search/rescue fleet." Prince George Citizen, July 27, 2007, 6; Pugliese, "DND should rewrite requirements for \$3B search aircraft project: NRC”, 2010, A1.
} 
was "little money available for the search-and-rescue project". ${ }^{188}$ In early 2007 DND officials had quietly told aerospace manufacturers that the lack of cash due to the Afghanistan affiliated projects meant that the FWSAR was stalled for "several years", even though publicly they insisted that work was continuing on the project's SOR and money was still available. ${ }^{189}$ The Afghanistan war also negatively impacted DND’s ability to spend money. In 2009 the department actually had to return $\$ 300$ million to the Treasury Board because defence bureaucrats were unable to provide timely information to their senior managers on recommendations for spending the money. ${ }^{190}$

Also noteworthy is how the Afghanistan war factored into the pre-NRC requirements. The air force initially justified the purchased of the C-27J on the basis that it could undertake missions on short runways like those used to resupply bases in Afghanistan (even the C-130 Hercules was not capable of doing this). However, this ceased to be a consideration once Canada's combat mission ended in 2011. And finally, with respect to possible influence of alliance politics, the air force did initially justify the C-27J because the U.S. Air Force was using it for transport. There is however no evidence that the Canadian air force's southern counterparts were pushing them to go with the Spartan; this justification fell away once the Obama administration axed the $\mathrm{C}-27 \mathrm{~J}$ fleet in $2012 .{ }^{191}$

\footnotetext{
${ }^{188}$ Confidential Source, Telephone interview with the Author, January 23, 2017; Pugliese, David. "Afghan war leaves Forces unable to buy new search planes." The Ottawa Citizen, April 26, 2007, A1; The Canadian Press, "Flying Buffalos not extinct - yet." The Halifax Daily News, October 22, 2007, 9.

189 Pugliese, "Afghan war leaves Forces unable to buy new search planes", 2007, A1.

190 The Canadian Press. "Snooze, lose: Defence department gave up \$300M due to foot dragging." Prince George Citizen, May 13, 2009, 14.

${ }^{191}$ Byers, "Needed: A big yellow plane that can hang from the sky," 2012, A12.
} 


\section{Bringing It All Together}

Is the political executive responsible for contributing to delays on the FWSAR project? Partly. Using the bureaucratic politics model it is clear in the Canadian context that the political executive failed in both providing policy clarity to the roles of the aircraft, and the project's priority among so many simultaneous and competing CAF fleet replacements. Crucially, the 2005 and 2008 defence policy announcements on the FWSAR did not state whether the replacement aircraft was to be dual role, with both transport and SAR functions like some of the C-130s, or simply a SAR-only aircraft like the Buffalos. This was a critical point considering that the project was replacing two different types of aircraft, of very different sizes and capabilities. With Air Command and DND determined to get the C-27J because of its C-130-like transport capabilities, amid a domestic market with no alternatives, the lack of policy guidance endorsed by the political executive (in the form of the Canada First Defence Strategy, for example), created a policy vacuum that was filled by competing bureaucratic interests from the three departments.

The overall effect of this policy vacuum was compounded by the absence of an interdepartmental governance structure (like that used in the 1980 New Fighter Aircraft project). The absence of such a structure until 2012, when the FWSAR Secretariat was formed, contributed to infighting over the SOR drawn up by the air force and DND. PWGSC and IC concerns over the SOR not possibly being in line with the government's Contracting Policy and IRBs' regime prevented the three departments from endorsing the project for implementation. In fact, when the project did go before cabinet, as had happened in 2005, the respective PWGSC and IC ministers were opposed to the planned approach and it was subsequently rejected. 
Tellingly, the Harper Conservatives repeated the error of their Liberal predecessors and sought to move the FWSAR project along the same SOR, sole-source approach in 2008-2009 where similar departmental opposition emerged. Connected to this issue was the lack of vetting of the SOR to begin with. Few in the political executive ever asked why the RCAF needed a plane capable of performing SAR Tech jumps and flying in the Arctic when neither of these activities occur often - a point brought out by the National SAR program's own statistics. Instead, in the words of a senior government official, what the air force wanted was "a really cool piece of kit". ${ }^{192}$ This lack of proper vetting led to a SOR moving forward that did not actually reflect or meet the air force's operational demands accurately. In this sense, the FWSAR "is a microcosm of the greater problems and that is really challenging the need". ${ }^{193}$

Therefore, DND and Air Command deserve their share of the blame for writing the SOR in a way that favoured the C-27J, and doing it under the guise of having a fair process. With the opposition generated from PWGSC and IC over this attempt at what one official described as a "fake competition", DND and Air Command should have just stated up front that they preferred the C-27J and thus avoided years of costly process from both government and industry. ${ }^{194}$ In a similar vein, former ADM (Mat), Alan Williams, wrote in 2006 that the FWSAR SOR was problematic and that inter-departmental malaise could have been avoided if the military had written the SOR "in true performance terminology" (as the NRC recommended four years later in 2010.) Politically, the performance or capabilities-based SOR would have allowed the minister of national defence to "publicly state that the government is not restricting competition", and

\footnotetext{
192 Senior Government Official (ret'd.), September 26, 2016.

193 Ibid.

${ }^{194}$ Confidential Source, Telephone interview with the Author, January 5, 2017.
} 
thus avoid the headaches that came from inter-departmental tension and industrial lobbying. ${ }^{195}$ Tellingly, the experience of the FWSAR project was key to influencing the 2014 Defence Procurement Strategy (more in Chapter Seven) and the need to create a Third Party Independent Panel to evaluate Statements of Requirements. ${ }^{196}$

Moreover, disputes over the SOR saw an additional exogenous factor, industrial lobbying, take a more prominent role in delaying the project. This lobbying increasingly made the FWSAR a politically risky project for any government to be associated with. ${ }^{197}$ Bombardier continued, throughout both the Martin and Harper governments, to use its position as Canada's only aircraft manufacturer, (with its home base in Quebec) to drum up ministerial support and force the SOR to be rewritten in a way that allowed the Montreal firm to submit either its Dash- 8 or Q400 design as an entrant. This situation did not go unnoticed by senior CAF officers. ${ }^{198}$ In the case of the Chrétien and Martin governments, Bombardier's lobbying was enough to scare ministers into opposing the military's FWSAR plans. When the Harper government was in power, Bombardier was known to call the Prime Minister's Office to voice objections. The combination of industry pressure and bureaucratic infighting over the SOR eventually led the Harper political executive to halt the project pending the NRC review in 2009-2010. That review precipitated a two year delay as a new SOR had to be written that incorporated the NRC's recommendations of capabilities' based on open competition. Like the NSPS model, on which it

\footnotetext{
195 Williams, Reinventing Canadian Defence Procurement: A View from the Inside, 2006, 40.

${ }^{196}$ Confidential Source, Telephone interview with the Author, January 5, 2017.

${ }^{197}$ Pugliese, David. “Canada still can’t land search and rescue planes.” Alberni Valley Times, April 6, 2010, A7.

${ }^{198}$ Confidential Source, Telephone interview with the Author, January 18, 2017.
} 
was based, the new FWSAR Secretariat governance structure, announced in 2012, provided the political executive with distance on project decision-making over both the SOR and RFP.

Finally, the Afghanistan war impacted the acquisition timeline for the FWSAR by reprioritizing DND's human and fiscal resources towards supporting the purchasing of missionspecific equipment. However, the Harper Conservatives also wanted to prioritize their own procurement projects promised in the 2005-2006 federal election (chiefly the strategic and tactical airlift projects), a point that became clear in the June 2006 'Canada First' procurement announcements. With the FWSAR having failed to make it on to the Conservatives' 'procurement radar', the project management office was consequently wound down in 2006 and would not reopen until the release of the CFDS in 2008. However, it can also be argued that the FWSAR failed to be a major priority for the air force too, especially once the C-17s and C-130Js aircraft were introduced. While the spare parts shortage and maintenance costs became more pressing concerns in the 2000s, given the age of the existing fixed-wing SAR fleets, the fact is that Air Command/RCAF was able to meet its aeronautical responsibilities in the National SAR program. ${ }^{199}$ Likewise, while SAR duties are some of the most visible public signs of the CAF, search-and-rescue makes up only a fraction of defence expenditures and personnel. In 2012-2013 the DND/CAF's entire cost for federal SAR participation was averaging \$227 million per year, with an estimated 800 personnel or roughly 1 percent of total defence budget expenditures and personnel. ${ }^{200}$ Perhaps most indicative of this lack of internal defence priority was the air force's ability to convince the political executive to approve the purchase of a fifth $\mathrm{C}-17$ in 2015 for US\$169 million during a time of steep defence budget cuts and despite the need for a five

\footnotetext{
${ }^{199}$ Canada. National Defence and the Canadian Armed Forces. Chief Review Services: Evaluation of the DND/CAF Contribution to the National SAR Program (2015).

${ }^{200}$ Ibid., 4.
} 
aircraft C-17 fleet never established as a defence policy requirement in the CFDS or June 2006 Canada First announcement. ${ }^{201}$

${ }^{201}$ Brewster, Murray. “Air force pushed for new plane despite budget axe.” Prince George Citizen, May 27, 2014, A8. 


\section{Chapter 6 - Halifax Class Modernization/Frigate Life Extension}

\section{Introduction}

It was one of the "most complex naval procurements undertaken by the material group since the original Canadian patrol frigate program in the early 1990s" and yet the Halifax-class Modernization/Frigate Life Extension (HCM/FELEX) project stands out for being on budget and subject to very few delays. ${ }^{1}$ The RCN's Director General for Naval Readiness has called the project, "a great Canadian success story". ${ }^{2}$ The University of Ottawa’s Telfer Centre for Executive Leadership has uses the HCM/FELEX as a case study in their graduate program on how to do complex procurements right. ${ }^{3}$ Canadian defence scholar Rob Huebert refers to the mid-life refit of the twelve vessel Halifax-class frigates as a bright light among an otherwise bleak media environment when it comes to defence procurement. ${ }^{4}$

Amid such praise the HCM/FELEX also achieved that rarest of Canadian naval procurement successes: export opportunities. In 2014, the Royal New Zealand Navy, impressed by what the HCM/FELEX prime contractors had achieved in Canada, signed a NZ\$446 million contract to have their two $A N Z A C$-class frigates modernized at the Seaspan yard in Victoria, BC. Chile's navy has followed suit, awarding a contract in 2017 to Lockheed Martin Canada, another HCM/FELEX prime contractor, to install a similar combat management system on its Type-23

\footnotetext{
${ }^{1}$ Canada. House of Commons. Standing Committee on National Defence, Evidence, $1^{\text {st }}$ session, $42^{\text {nd }}$ Parliament, Meeting No. 28, November 17, 2016.

${ }^{2}$ Pugliese, David. "More than half Canada's Navy vessels are either repaired, modernized or otherwise at reduced readiness.” National Post, April 20, 2014.

${ }^{3}$ Gunn, Andrea. "Halifax-class frigate refits over half done." Chronicle-Herald, December 25, 2015; Lerhe, Eric. "Sailing into the future." Policy Options, December 9, 2015; Dempster, Doug. "Navigating Complexity: A tale of three projects." Vanguard, August/September 2015, 32.

${ }^{4}$ Huebert, Rob. The Royal Canadian Navy: Facing Rough Seas (Calgary: Canadian Global Affairs Institute, 2016), $1,7-8$.
} 
frigates. ${ }^{5}$ Some ten foreign governments showed interest in hiring HCM/FELEX-affiliated firms. ${ }^{6}$ The paradox is that little has been written about the HCM/FELEX, even though at $\$ 4.3$ billion, it cost as much as the MSVS-SMP and JSS combined, and completely revamped the 'backbone' of the RCN's fleet between 2010 and 2017. It managed to replace the ships weapons, communications, sensors and command and control systems with a small schedule slippage of only a few months. The modernization was so extensive that Vice-Admiral Mark Norman referred to them in 2014 as a "new class of ship, notwithstanding the fact that it's the recapitalization of an existing capability."’

The lack of public awareness can be partially attributed to the nature of the project: modernization projects are not new platforms and therefore do not elicit as much political or media commentary. ${ }^{8}$ The HCM/FELEX also benefitted from a lower public risk profile: Canadian firms and bureaucrats had decades of experience performing maintenance and upgrades to existing naval ships with little controversy (Victoria-class submarines aside). ${ }^{9}$ This is in contrast to the Joint Support Ships, which were intertwined with rebuilding the shipbuilding industry, and with issues of regionalism over shipyard selection (as detailed in Chapter Three). A final factor is that the project was a success; by default, it never attracted the level of heightened

\footnotetext{
${ }^{5}$ New Zealand. Ministry of Defence. "ANZAC ships upgrade frigate systems upgrade (FSU)". Accessed online July 8, 2017: http://www.defence.govt.nz/what-we-do/delivering-defence-capability/defence-capability-projects/anzacships-upgrade-frigate-systems-upgrade-fsu/; "Canadian Solution Selected by the Armada de Chile for Frigate Combat Management System Replacement Program.” Lockheed Martin Canada. Accessed online July 6, 2017: http://www.lockheedmartin.com/ca/news/2016/canadian-solution-selected-by-the-armada-de-chile-for-frigateco.html.

${ }^{6}$ Vanguard Staff, "Frigate's new combat systems find international interest." Vanguard, December/January 2015.

${ }^{7}$ Canada. House of Commons. Standing Committee on National Defence. Vice Admiral Mark Norman, November 18, 2014.

${ }^{8}$ Senior Government Official, Interview with the Author, September 23, 2016.

${ }^{9}$ Confidential Source, Telephone Interview with the Author, January 17, 2017.
} 
media or political attention given to the more problematic procurements discussed in this dissertation.

Yet despite the accolades, the success of the HCM/FELEX project was hardly a given. In the words of one official, it was the project that should have failed given the sheer number of complexities involved..$^{10}$ Most MCPs have one prime contractor, the HCM/FELEX project had six: Seaspan Shipyards in Victoria, Irving Shipyards in Halifax, Fleetway Incorporated, Boeing, DRS Flight Safety and Communications, and Lockheed Martin Canada. Moreover, refits were carried out at two shipyards on opposite ends of the country: the seven frigates of the RCN's East Coast fleet were overhauled in Halifax while the five frigates of the West Coast fleet were modified in Victoria, near CFB Esquimalt. ${ }^{11}$

Although the first refits began in 2010, planning for the HCM/FELEX started in $2002 .{ }^{12}$ The initial aim was a life extension (FELEX) project to replace and repair enough of the ships' original operating systems, hull and superstructure to ensure their operation for another two decades until a new replacement, the Canadian Surface Combatant, entered service. The FELEX component was approved at Treasury Board in February 2005. However, there was a growing list of stand-alone upgrades, and a realization that the ships' original Cold War anti-submarine warfare and anti-surface warfare design was not adequate for the littoral operations Maritime Command/RCN had undertaken since the 1990s in often hostile environments like Libya in

\footnotetext{
${ }^{10}$ Perry, 2015 Status Report on Major Defence Equipment Procurements, 2015, 16.

${ }^{11}$ Canada. National Defence and the Canadian Armed Forces. 2017-18 Departmental Plan: Status Report on Transformational and Major Crown Projects. Accessed online July 7, 2017: http://www.forces.gc.ca/en/aboutreports-pubs-report-plan-priorities/2017-status-report-on-transformational-and-major-crown-projects.page\#p11.

${ }^{12}$ Canada. National Defence and the Canadian Armed Forces. "Halifax-class Modernization/ Frigate Life Extension (HCM/FELEX)”. Accessed online July 4, 2017: https://www.canada.ca/en/department-nationaldefence/news/2016/11/halifax-class-modernization-frigate-life-extension-felex.html.
} 
$2011 .^{13}$ This meant that new weapons and sensors were needed as well. Therefore, upon DND's prompting in February 2007, Treasury Board approval was given for the modernization, or HCM, component to be merged with the FELEX in order to maximize the amount of upgrade projects that could be completed with the ships in dry-dock and out-of-service. ${ }^{14}$

Under the HCM/FELEX umbrella the Halifax-class frigates received a new combat management system: 'Harpoon' missiles capable of hitting land targets (a key resource necessary for littoral operations); electronic warfare measures; internal communications upgrades; modified $57 \mathrm{~mm}$ naval guns; shield II missile decoy countermeasures; interrogator friend or foe mode ' $\mathrm{S} / 5$ '; navigation radars; new integrated machinery control systems; and a long-range infrared search and track system. ${ }^{15}$ With the navy losing its area command and control capabilities with the decommissioning of the Iroquois-class destroyers in 2014-15, a scaled down Task Group commander capability was added to four of the twelve ships. ${ }^{16}$ Following the release of RFPs in 2007 , the $\$ 1.2$ billion shipyard contracts were awarded to Seaspan and Irving, in March 2008. Lockheed (the sole bidder once General Dynamics quit the competition in June 2008) won the $\$ 2$ billion combat management system and in-service support contract in November 2008. The remaining \$1.1 billion stand-alone contracts were awarded over 2008-2009 with Lockheed responsible for integration. ${ }^{17}$ The first refits began in 2010 with the HMCS

\footnotetext{
${ }^{13}$ Perry, David. Leading From Behind is Still Leading: Canada and the International Intervention in Libya (Ottawa: Conference of Defence Associations Institute, 2012).

${ }^{14}$ Perry, 2015 Status Report, 36.

${ }^{15}$ Canada. National Defence and the Canadian Armed Forces. "Halifax-class Modernization/Frigate Life Extension (HCM/FELEX)".

${ }^{16}$ Canada. National Defence and the Canadian Armed Forces. 2014-2015 Report on Plans and Priorities: Status Report on Transformational and Major Crown Projects.

${ }^{17}$ Canada. National Defence and the Canadian Armed Forces. 2017-18 Departmental Plan: Status Report on Transformational and Major Crown Projects; Canada. National Defence and the Canadian Armed Forces. "Halifaxclass modernization and frigate life extension." Accessed online July 8, 2017: http://www.forces.gc.ca/en/businessequipment/halifax-frigate.page.
} 
Halifax and concluded in 2017 with the return to service of the HMCS Toronto and HMCS

Regina. Full operational capability of the entire fleet is slated for January $2018 .{ }^{18}$

A number of factors help explain the project's success. The principal factor was the urgency of ensuring that the RCN maintained a modern surface combatant fleet to bridge an impending operational gap that was to have emerged between the decommissioning of the aging Iroquois-class destroyers (in the 2010s) and the introduction of the first Canadian Surface Combatants (in the late-2030s). ${ }^{19}$ DND and Maritime Command/RCN officials were initially "scared at [the] beginning" given the scale of the modernization. ${ }^{20}$ For this reason, HCM/FELEX was posited as a 'no fail' Major Crown Project which DND/CAF had to make a priority. Connected with the issue of an impending operational gap was the technological gulf that opened between the early 1990s, when the Halifax-class ships were built, and the mid-2000s. Ships that were at their prime two decades ago were increasingly falling behind their allied counterparts in performance and hence interoperability drove the need for an effective and efficient modernization. This was not an easy feat, given the rapid growth of technology and information systems since the 1990s. As one analyst noted, the HCM/FELEX technological upgrades were "like replacing a Commodore 64 with the latest in computer technology". ${ }^{21}$ The project also benefitted from a unique governance model known as the Committee of Sponsors (CoS). The Committee featured representatives from each of the prime contractors plus senior government officials. A last factor is that delays were said to have been avoided by DND's insistence that the

\footnotetext{
${ }^{18}$ Canada. National Defence and the Canadian Armed Forces. 2017-18 Departmental Plan: Status Report on Transformational and Major Crown Projects.

${ }^{19}$ Webb, Stewart and Chris Murray, Canada's hidden plan for predicted failure: Planning for the Introduction of the Canadian Surface Combatant (Calgary: Canadian Global Affairs Institute, 2016), 3.

${ }^{20}$ Confidential Source, Telephone interview with Author, January 18, 2017.

${ }^{21}$ Dobson, Carl. "New frigate systems deliver new capability." Vanguard (Feb/Mar 2013. Accessed online September 9, 2016: http://www.vanguardcanada.com/2013/03/20/new-frigate-systems-deliver-new-capability/
} 
modernization use as much non-U.S. technology as possible to avoid U.S. export regulations. ${ }^{22}$

Table 6 below provides an overview of the key process milestones in the HCM/FELEX project.

The original dates established for advancing the project through the procurement process are

compared to when they were achieved.

\begin{tabular}{|c|c|c|c|}
\hline \multicolumn{4}{|c|}{ Table 6 - HCM/FELEX Project Milestones ${ }^{23}$} \\
\hline Stage & Original Date & 2014 & 2017 \\
\hline Project Identification & 2002 & $\checkmark$ & $\checkmark$ \\
\hline Options Analysis Completed & -- & -- & -- \\
\hline Project Definition (PPA) & $\begin{array}{l}\text { FELEX: February } \\
2005 \\
\text { HCM/FELEX: } \\
\text { February } 2007\end{array}$ & $\checkmark$ & $\checkmark$ \\
\hline $\begin{array}{l}\text { Refit Procurement Strategy } \\
\text { Approval by Treasury Board }\end{array}$ & March 2007 & $\checkmark$ & $\checkmark$ \\
\hline Revised PPA Approval & June 7, 2007 & $\checkmark$ & $\checkmark$ \\
\hline Shipyard Contract Awards & October 2007 & March 2008 & $\checkmark$ \\
\hline $\begin{array}{l}\text { Combat System Integration } \\
\text { Award }\end{array}$ & September 2008 & November 2008 & $\checkmark$ \\
\hline Implementation (EPA) & April 2008 & September 2008 & $\checkmark$ \\
\hline Refits Begin & April 2010 & October 2010 & $\checkmark$ \\
\hline First Delivery & -- & January 2015 & $\checkmark$ \\
\hline Final Delivery & January 2018 & January 2018 & 2018 \\
\hline Project Close Out & April 2018 & January 2019 & 2019 \\
\hline
\end{tabular}

\footnotetext{
${ }^{22}$ Perry, 2015 Status Report, 36; Dempster, "Navigating Complexity: A tale of three projects.”; Huebert, The Royal Canadian Navy: Facing Rough Seas, 2016, 8.

${ }^{23}$ Dates come from a combination of the following sources: Canada. National Defence and the Canadian Armed Forces. 2006-2007 Report on Plans and Priorities (Ottawa: 2006), 36; Perry, 2015 Status Report, 36; Canada. Treasury Board of Canada Secretariat. National Defence: Departmental Performance Reports 2007-08: Status Report on Major Crown Projects (Ottawa: 2008); Canada. Department of National Defence. "Status Report on Transformational and Major Crown Projects." Accessed online June 26, 2017: http://www.forces.gc.ca/en/aboutreports-pubs-report-plan-priorities/2017-status-report-on-transformational-and-major-crown-projects.page\#p 11; Canada. National Defence and the Canadian Armed Forces. Report on Plans and Priorities 2014-15: Status Report on Transformational and Major Crown Projects (Ottawa: 2015).
} 


\section{Political Executive Decisions}

\section{a. The Early Years (2001-2005)}

The first political executive decisions made on the HCM/FELEX project were indirect and began in 2001. That year, the Chrétien government approved the industrial shipbuilding policy discussed in Chapter Three. A New Policy Framework For The Canadian Shipbuilding and Industrial Marine Industry made it official that all federal shipbuilding, maintenance and upgrading were to occur competitively among Canadian shipyards. ${ }^{24}$ This policy effectively removed the option of upgrading the frigates (or any naval ship for that matter) overseas as New Zealand did in 2014. It simultaneously made it clear that any future upgrading opportunities on federal ships was to be primarily about supporting the domestic shipbuilding industry. However, the policy also meant that an estimated two years, 2005-2007, were spent structuring a competition to select Canadian shipyards to undertake the modernization project. In reality, both Seaspan and Irving were the only feasible competitors; they had each acquired years of experience performing maintenance on the ships and were in close proximity to the respective home ports.

The second decision that year occurred shortly after the September 11, 2001 terror attacks; the Chrétien government ordered Maritime Command to southwest Asia as a part of Operation Apollo. (Op Apollo was the official name for CAF activities connected to the U.S.-led response against al-Qaeda). This deployment, which lasted two years, involved 95 percent of the navy's sea-going sailors and fourteen of the fifteen combined Halifax-class frigates and Iroquoisclass destroyers. Op Apollo was the most intense naval deployment since the Second World War.

\footnotetext{
${ }^{24}$ Canada. Industry Canada. A New Policy Framework For The Canadian Shipbuilding and Industrial Marine Industry (Ottawa: 2001).
} 
The deployment consumed an already low supply of the frigates' spare parts and took a toll on the ships' operating systems and hulls. ${ }^{25}$ Naval historian Marc Milner has argued that the $O p$ Apollo mission "stretched the Canadian Forces, and the navy, to the breaking point" by acerbating the impact of defence cuts made by the Chrétien government in the 1990s. ${ }^{26}$

Given the frigates' deterioration, attempts were made by senior CAF officers between 2001 and 2005, to get funding for a frigate life extension and capabilities modernization project. In 2004, during the Paul Martin government, Vice Chief of Defence Staff, Vice-Admiral Ron Buck, attempted to get $\$ 2$ billion earmarked for such a project, but lost out to the Martin government's new healthcare funding arrangement with the provinces (then considered the Liberals' top priority). ${ }^{27}$ Relief finally came in 2005 with the commitment to $\$ 7$ billion in new defence spending and a new defence policy. Without naming the frigates specifically - likely because there were multiple projects requiring upgrades (e.g. CP-140 'Auroras') - the 2005 budget recognized the impact of the "high tempo of operations" since 2001 and that purchases of spare parts, repairs and upgrades "have been delayed or missed to support the high operational demands". ${ }^{28}$ Estimated at $\$ 1.1$ billion, the FELEX project received $\$ 28$ million to establish a project management office following Treasury Board's Preliminary Project Approval in February $2005 .{ }^{29}$ In April a new cabinet approved defence policy, the Defence Policy Statement, went into more detail, specifying that modernized frigates were a CAF priority. The ships would

\footnotetext{
${ }^{25}$ Fisher, Matthew. “'Tired' navy limps home from gruelling Gulf mission,” Ottawa Citizen, September 21, 2003,. A3. Noted one seaman, "Parts of the Calgary have already been here on the Regina and now parts from the Regina, the Vancouver, and several other ships are here on board the Calgary."

${ }^{26}$ Milner, Marc. Canada's Navy: The First Century (Toronto: University of Toronto Press, 2010), 320.

${ }^{27}$ Pugliese, David. “Canada's frigates need \$2B upgrade: Crews forces to shuttle equipment from one warship to another." Ottawa Citizen, April 17, 2004, A1.

${ }^{28}$ Canada. Department of Finance. The Budget Plan 2005 (Ottawa: 2005), 220.

${ }^{29}$ Canada, Department of National Defence. "Halifax Class Modernization/Frigate Life Extension (HCM/FELEX)." Major Crown Projects: 2006-2007 (2006); Canada. Department of National Defence. "Frigate Life Extension (FELEX)." Major Crown Projects: 2007-2008 (2007).
} 
receive new "combat systems and electronics" and the ability to perform littoral operations and strike land-based targets. The objective of these upgrades would be to give the frigates the ability to "participate in Alliance and coalition operations" and "support and protect forces operating ashore". 30

\section{b. The Harper Years (2006-2015)}

During the 2006 federal election campaign the Conservatives committed to modernizing the frigates in their party platform. ${ }^{31}$ However, the project did not receive a mention in the June 2006 'Canada First Defence Procurement' announcement. There are likely several reasons for this: First, the FELEX project definition work was still ongoing. Secondly, the project was already approved by and associated with the previous Liberal government. More importantly though was the fact that the frigate modernization project had "low political interest" within the Harper government; in fact as a policy item it did not go before cabinet at all. ${ }^{32}$ The HCM/FELEX remained low on the "problem files" throughout the Harper government's time in power for the very reason that it was not seen as politically sensitive. ${ }^{33}$ Although it was technically complex, the political executive in the Harper era understood the project's urgency. To quote one senior PMO official, it was "easy to communicate and easy to understand for ministers". ${ }^{34}$ Meanwhile, the Harper government adopted the Liberals' 2001 shipbuilding and maintenance industrial policy in late-2006, reinstating the view that economic development is the primary goal of federal shipbuilding and maintenance policy. ${ }^{35}$

\footnotetext{
${ }^{30}$ Canada. Department of National Defence. Defence Policy Statement (Ottawa: 2005), 14.

${ }^{31}$ Perry, 2015 Status Report, 36.

${ }^{32}$ Senior Government Official (ret'd.), Interview with the Author, September 23, 2016.

${ }^{33}$ Senior Government Official (ret'd.), Interview with the Author, September 26, 2016.

${ }^{34}$ Senior PMO Official (ret'd.), Interview with the Author, December 10, 2016.

${ }^{35}$ Ring, Tom. The National Shipbuilding Procurement Strategy: How did we get to where we are now? (Calgary: Canadian Global Affairs Institute, 2016), 2.
} 
In February 2007, based on the recommendation of DND, Treasury Board ministers granted a revised Preliminary Project Approval for the merger of the FELEX with the HCM capabilities into one overarching umbrella project. With $\$ 63$ million set aside for the project management office and definition work, the estimated budget for the new combined HCM/FELEX was increased to $\$ 3.1$ billion. ${ }^{36}$ Due to the heightened risks associated with the expanded project, Treasury Board was involved in approving the procurement strategy for the project in March 2007. In June 2007, Treasury Board gave a revised Preliminary Project approval as another $\$ 1$ billion in Halifax-class upgrade projects were added to the HCM/FELEX umbrella, pushing the project up to $\$ 4.3$ billion. ${ }^{37}$ Even though contract awards for the shipyards were not planned until 2008 and the first ship refit not set to begin until 2010, the Harper government sought to promote the economic benefits of the project in July 2007, following the release of the respective RFPs. The minister of national defence, Peter MacKay, went so far as to write a letter to Nova Scotian newspapers promoting the HCM/FELEX benefits to the region. ${ }^{38}$ Such actions reflected what was widely seen within the political executive at the time as a "good announcement" and a "political win" given the dollars and jobs involved; it was also a demonstration of the Harper government's commitment to the CAF. It was no surprise then the HCM/FELEX enjoyed a lot of support at the cabinet level despite being a low political priority. ${ }^{39}$

The next political executive involvement occurred in March 2008 when Effective Project Approval was given to Seaspan and Irving to undertake the refits in their yards. In September 2008, EPA was granted to Lockheed Martin Canada, the sole remaining bidder in the $\$ 1.1$ billion

\footnotetext{
${ }^{36}$ Canada. Department of National Defence. Major Crown Projects: 2006-2007.

${ }^{37}$ Perry, 2015 Status Report, 36; Canada. Treasury Board of Canada Secretariat. National Defence: Departmental Performance Reports 2007-08.

${ }^{38}$ MacKay, Peter. "Ships' refit good news." The Halifax Daily News, July 11, 2007, 13.

${ }^{39}$ Senior PMO Official (ret'd.), Interview with the Author, December 10, 2016.
} 
combat system contract. Lockheed was formally awarded the contract two months later in November after it was deemed to be compliant with all mandatory requirements and was assessed as having no unacceptable risks. ${ }^{40}$ The discrepancy between announcing Lockheed's award and the formal confirmation of its bid two months later was not likely a coincidence and can perhaps partly explain why the original spring EPA date was delayed. Throughout the summer anticipation had been building for a fall federal election. The Harper government's announcement of the $\$ 1.1$ billion combat systems component of the HCM contract, five months after the joint $\$ 1.2$ billion contracts for the Victoria and Halifax shipyards, was said to be part of a 'feel good' roll-out of big spending in the lead-up to a possible fall vote. ${ }^{41} \mathrm{With}$ the contracts for the shipyards and combat system awarded the HCM proceeded onto preparing for the first refit in October $2010 .^{42}$

Finally, there was an indirect political executive impact on the HCM/FELEX procurement shortly after the refits began. The Harper Conservatives implemented the first in a succession of defence budget cuts from 2010 to 2014 to offset the recession deficit spending undertaken in 2009-2010. Amid this belt-tightening, DND was forced to prioritize its human and fiscal resources. It took those actions needed to "execute vessel maintenance activities" on the Halifax-class frigates and Victoria-class submarine in-service support contract, the only projects designated as such. ${ }^{43}$ The prioritizing of the HCM/FELEX is most apparent when compared to

\footnotetext{
${ }^{40}$ Canada. Department of National Defence. "Halifax Class Modernization/Frigate Life Extension (HCM/FELEX)", Major Crown Projects: 2009-2010 (2009).

${ }^{41}$ Pugliese, David. "Frigate deal part of campaign barrage; Tories to announce $\$ 1.1$-billion upgrade by lone bidder Lockheed Martin Canada." Times Colonist, September 8, 2008, A5.

${ }^{42}$ Canada. National Defence and the Canadian Armed Forces. "Halifax-class modernization and frigate life extension." Accessed online July 7, 2017: http://www.forces.gc.ca/en/business-equipment/halifax-frigate.page.

${ }^{43}$ Canada. Department of National Defence. National Defence: 2010-2011 Report on Plans and Priorities (Ottawa: 2010), 28; Canada. Department of National Defence. National Defence: 2011-2012 Report on Plans and Priorities (Ottawa: 2011), 25.
} 
the navy's other classes of ships. Defence cutbacks in 2010 saw six of the twelve Kingston-class maritime coastal defence vessels tied-up at the dock while three frigates were assigned to limited domestic operations. Meanwhile, plans for purchasing anti-missile systems for the two Protecteur-class AORs were withdrawn. The three remaining Iroquois-class destroyers each saw their anti-submarine warfare capabilities axed. Smaller support vessels were not spared either; nearly 60 percent of the maintenance budget for such vessels, e.g. tugboats, was cut that year. ${ }^{44}$

\section{Exogenous Explanations}

\section{a. Defence Procurement Bureaucracy}

$\underline{D N D / C A F}$ : From the beginning of the project's conception in the early-2000s, DND and the CAF viewed the HCM/FELEX as a 'no fail' mission: "if the frigates were left in drydock you'd be left with a coastal navy". ${ }^{45}$ The dozen frigates of the Halifax-class constitute the backbone of the navy's surface combat fleet and since the 1990s have been a key part of the navy's Naval Task Group (the main organizational formation relied upon for deployments). The Task Group is comprised of up to four combatant vessels - destroyers, frigates, and a submarine - supported by an AOR like the Joint Support Ship. The composition of these vessels allows for a sustained deployment capable of both providing defensive and offensive military capabilities. ${ }^{46}$ Modernizing these ships so they could remain in service was deemed a force generation priority

\footnotetext{
${ }^{44}$ Pugliese, David. "Cash-strapped navy could take out ships.” Times Colonist, May 13, 2010 , A1.

${ }^{45}$ Confidential Source, Telephone interview with the Author, January 17, 2017.

${ }^{46}$ Canada. National Defence and the Canadian Armed Forces. Leadmark 2050: Canada in a New Maritime World (Ottawa: 2016), 43.
} 
and remained the focus of National Defence's resources, especially during the cutbacks in the later years of the Harper government. ${ }^{47}$

However, by the early 2000s a combination of factors contributed to a sense of urgency by defence officials to initiate a frigate modernization project. The most prominent of these were a changed international security environment, the impending retirement of the 40 -year old Iroquois-class destroyers, and the fact that a future replacement - the Canadian Surface Combatant - was not likely to appear until the late-2030s. Such circumstances left defence officials with a clear need for a modernized Halifax-class to bridge the surface combat fleet for another two decades. ${ }^{48}$ In this sense, as one former senior official put it, the modernization project was "one of the most realistic projects" because Maritime Command/RCN was "keenly aware of what could be done and what they needed to do...".49

With respect to the first factor, the ships which entered service between 1992 and 1996 encountered a different security environment than that for which they were originally designed. The navy began conceptualizing what would become the Halifax-class frigates in the early 1970s. Then known as the Canadian Patrol Frigate program, the project emerged out of the rejection of a modernization of the aging Mackenzie-class destroyers and the added pressure from NATO for Canada to update its navy. These issues became acute when in 1977 Canada became party to the expansive 200-mile Exclusive Economic Zone. Criticisms from within the defence establishment, having already been stoked by the 1975 Defence Structure Review's call

\footnotetext{
${ }^{47}$ Canada. Department of National Defence. National Defence: 2008-2009 Report on Plans and Priorities (Ottawa: 2008), 33-34.

${ }^{48}$ Ibid., 43.

${ }^{49}$ Senior Government Official (ret'd.), Interview with the Author, September 26, 2016.
} 
for government reinvestment in the CAF, mounted as the navy's aging fleet was now having to contend with patrolling a massive area of ocean 200 miles from the country's coastline. ${ }^{50}$

Therefore, when conceived during the late-1970s and early-1980s, the Halifax-class frigates were designed with a specific mission in mind: extended ocean patrols and a mix of antisubmarine warfare and anti-surface warfare in the North Atlantic (as a part of Canada's Cold War alliance duties under NATO). The end of the Cold War and the transformation of the global international security situation saw the Halifax-class frigates utilized on a wider spectrum of missions: anti-piracy operations on the Horn of Africa, humanitarian relief, maritime deterrence patrols in the Baltic Sea, and even combat operations off the coast of Libya (in 2011). ${ }^{51}$ Such varying missions tested the vessels' capabilities in situations that were not thought of in the 1970s and 1980s. Therefore, naval planners recognized that an update was necessary to ensure that the navy had a deployable, surface combat capability for the next fifteen to twenty years that would meet the operational needs of a post-Cold War environment while a replacement (the Canadian Surface Combatants) was being built.

While the vessels' operational needs might not have been foreseen three decades previous, the need for a refit was planned into the Halifax design. Keeping in line with global naval shipbuilding standards, the frigates were built with a 35-40-year operational lifespan, double what was expected for ships built during the Second World War. Other Maritime Command fleets acquired in the 1970s, for example, the Protecteur-class Auxiliary Oil Replenishment ships and the Iroquois-class destroyers, all served over 40 years before the last of

\footnotetext{
${ }^{50}$ Milner, Marc. Canada's Navy: The First Century (Toronto: University of Toronto Press, 2010), 272, $276-277$.

${ }^{51}$ Canada. Department of National Defence. "Halifax-Class Modernization (HCM) / Frigate Life Extension (FELEX).” Backgrounder, November 24, 2014. Accessible online: http://www.forces.gc.ca/en/news/article.page?doc=halifax-class-modernization-hcm-frigate-life-extensionfelex/hkm9beb0
} 
each class were decommissioned between 2014-2017. The need for longer lifespans was the result of rapid changes in technology, a corresponding need to update weapons and sensors, and the increase in shipbuilding costs. Simply put, a modern warship is too expensive to build and operate for it to be regularly replaced at fifteen year intervals. Because of such expensive factors, refitting is much more cost effective than building new ships. When the Halifax-class were designed, a fifteen year lifespan was allocated to their combat systems; this effectively meant that the weapons, sensors, and communications system would have to be replaced by the early 2010s. The navy did at one point look at replacing the Halifax-class altogether in exchange for pursuing an upgrade. However, according to the Canadian Naval Review, an internal analysis determined that the per unit cost of replacing the twelve frigates with a new fleet would be in the range of $\$ 1.2$ billion to $\$ 1.5$ billion, for a total cost of $\$ 14.5$ billion to $\$ 18$ billion. ${ }^{52}$ In comparison, the total cost of refitting the Halifax-class was $\$ 4.3$ billion, or about one quarter of the expense of a replacement.

The need for an refit became apparent as early as 2000, just five years after the Halifaxclass fleet became fully operational. Initially, frigate modernization was being done piece-meal. In 2000 the navy successfully secured from the Chrétien cabinet, $\$ 516$ million to upgrade the frigates' Evolved Sea Sparrow missiles, used for defending the ships from aircraft and missiles. The navy made it known that it hoped that the Evolved Sea Sparrow upgrade would be the start of an eventual $\$ 3$ billion refit to begin in 2005. However, the scarce amount of interest and dollars committed to defence by the Chrétien government put off the project until the Martin government came to power. Even with the Evolved Sea Sparrows, the driving force in getting cabinet approval for the missiles was alliance pressure: the missiles were a joint NATO project

\footnotetext{
52 Thomas, Doug. “Warship Developments: Life Extension Refits.” Canadian Naval Review 8, No. 2 (2012): 41-42.
} 
that carried a major disincentive on the part of the Chrétien government to not delay approval lest Canada be responsible for driving up the cost of the missiles for Canada's allies. In the words of one observer, "Your partners in NATO require you to put up, or shut up."

The navy's own internal policy guidance document from a year later, (in 2001, Leadmark: The Navy's Strategy for 2020) made it clear that a FELEX project was necessary to keep the fleet operational. Specifically, the Halifax-class required new command and control functions, radars, sensors, communications and weapons. In light of the eventual designation of four modernized frigates with task force command capabilities, the navy recognized at the time that budget limitations might lead to the emergence of different "sub-classes of upgraded vessels"; that is, some ships would receive capabilities that the others would not. ${ }^{54}$

The desire to upgrade the frigates sooner rather than later was warranted. As it happened, concerns on the frigates' aging systems had emerged just a few years after the last ship was commissioned in 1996. In 2000, operational wear-and-tear and the need to acquire new task force command and land strike capabilities were identified by the navy's commander as a future priority. This was especially the case given the ages of the existing task force command ships, the four Iroquois-class destroyers (commissioned in 1972-73), and the role of sea-launched cruise missiles in the 1999 Kosovo conflict. ${ }^{55}$ While planning within DND/CAF for modernizing the frigates officially began in 2002 other government priorities delayed project approval by three years. ${ }^{56}$

\footnotetext{
${ }^{53}$ Pugliese, David. “Missile upgrade will beef up frigates' defence.” The Ottawa Citizen, December 2, 2000, A6.

${ }^{54}$ Canada. Department of National Defence. Leadmark: The Navy's Strategy for 2020 (Ottawa: 2001), 68.

55 Ward, John. "It's smooth sailing for Canada's new navy." Edmonton Journal, August 25, 2000, A17.

${ }^{56}$ Gunn, Andrea. "Halifax-class frigate refits over half done." Chronicle-Herald, December 25, 2015.
} 
In the interim, the complexity of the project (i.e. removing ships from service on both ends of the country and switching old equipment for new) became an incentive for DND and the navy to maximize the number of (growing) Halifax-class upgrade projects under one umbrella so as to avoid prolonged refits in the future. Defence budgetary shortfalls were forcing the navy to face a "constant uphill struggle to upgrade its frigates' floating suite of electronic sensors and weapons". In 2004, the quality of equipment had deteriorated to the point that sailors were moving equipment from ship-to-ship to ensure a deployed vessel maintained operational capability. Maritime Command had hoped for a modernization program to start as early as 2008 but money was not forthcoming. In accounting for why the government has not been pushing more cash into projects like the HCM, Allan Pellerin of the Conference of Defence Associations' Institute pinned the blame on "some bureaucrats and politicians" who did not want to acknowledge that "the military may one day have to fight". ${ }^{57}$ However, the more likely explanation is that the CAF faced budgetary competition against the Liberal government's other non-military priorities, chiefly healthcare..$^{58}$

Confronted with multiple stand-alone frigate modernization projects in 2005, in addition to the already sanctioned FELEX, ADM (Mat) Dan Ross moved to merge these projects all under one umbrella. ${ }^{59}$ DND's Senior Review Board approved the merger in October 2006 on the basis that a HCM/FELEX allowed for "project management advantages", "simplified accountability framework", and transferred "significant integration risk to a prime contract". ${ }^{60}$

\footnotetext{
${ }^{57}$ Wattie, Chris. “An 'irresponsible' way to run a navy." Ottawa Citizen, October 10, 2004, A3; Wattie, Chris. "March of technology leaves forces struggling." The Calgary Herald, October 3, 2004, B5; Pugliese, David. "Canada's frigates need \$2B upgrade: Crews forces to shuttle equipment from one warship to another." Ottawa Citizen, April 17, 2004, A1.

${ }_{58}^{58}$ Pugliese, "Canada's frigates need \$2B upgrade," 2004.

${ }^{59}$ Confidential Source, Telephone interview with the Author, January 27, 2017.

${ }^{60}$ Canada. Treasury Board of Canada Secretariat. National Defence: Departmental Performance Reports 2006-07: Status Report on Major Crown Projects (Ottawa: 2007).
} 
This allowed for a single Treasury Board submission in 2007 and consequently one competition instead of a submission and competition for every specific component that the frigates required. When compared to the multi-phase MSVS project (Chapter Four), this method is viewed as having avoided delays that would have been prompted by a 'domino' effect should one project fall behind. With Lockheed Martin Canada responsible for integrating the $\$ 2$ billion combat management system, DND and CAF transferred much of the risk management to a private vendor - although it limited the number of possible competitors. ${ }^{61}$ In pursuing this approach ADM (Mat) Ross was also conscious of the limited "bandwidth" that Treasury Board ministers and the Treasury Board Secretariat had in 2006-2007, given the large number of Afghanistanspecific procurement projects being sent their way. The one stand-out limitation to Ross's approach was that it came with a budget cap that punted other upgrade projects off to the future. ${ }^{62}$ One such project was the frigates' air conditioning systems which needed replacement to prevent the new combat systems from overheating when operating in tropical regions like the Caribbean. This $\$ 50$ million project will now occur after the frigates complete their refits and with some operational risk to the ships. ${ }^{63}$ In fact, in reviewing DND's own Defence Acquisition Guide Webb and Murray estimate that between $\$ 510$ million to $\$ 1.1$ billion in Halifax-class weapons systems and communications upgrades were not included in the HCM/FELEX but will need to be carried out to bridge the introduction of the much-delayed Canadian Surface Combatant (not due for delivery until at least 2036). Likewise, because little of the $\$ 4.3$ billion HCM/FELEX was spent on hull maintenance, the ships will require another refit or prolonged

\footnotetext{
${ }^{61}$ Confidential Source, Telephone interview with the Author, January 27, 2017.

${ }^{62} \mathrm{Ibid}$,

${ }^{63}$ Brewster, Murray. "Upgrading frigate air conditioning will cost navy $\$ 50$ million." CBC News. Accessed online July 9, 2017: http://www.cbc.ca/news/politics/frigate-air-conditioning-1.3933418.
} 
maintenance to ameliorate the effects of rust and corrosion on the ships' hulls or risk suffering the fate of the Iroquois-class destroyers or Protecteur-class AORs. ${ }^{64}$

DND/CAF also assisted in avoiding delays with their push for the HCM/FELEX's statement of requirements to include as little U.S.-made technology as possible. With the $\$ 2$ billion combat management system contract, DND required that Lockheed Martin Canada procure command and control equipment free of the U.S. International Traffic in Arms Regulations (ITAR). This stipulation was based on past CAF procurement experiences with Washington which used ITAR restrictions to delay equipment deliveries to Canada and thereby grew project costs due to inflation. ${ }^{65}$ ITAR was also invoked to influence what Canada could or could not do with the technology it acquired for its own armed forces. For example, when a Canadian firm manufactured software capable of locating road-side bombs the U.S. Department of Defense purchased it and invoked the ITAR to prevent sales of the product to other countries including Canada. ${ }^{6}$ An unsuccessful 2006 U.S. attempt to limit certain dual citizen Canadians from working on defence projects was also cited as a factor in pushing the DND towards its nonU.S. technology stipulation on Lockheed Martin Canada. To overcome possible ITAR associated delays, DND pushed for government-to-government foreign military sales agreements that allowed for buying "as good as US" equipment and software. It helped that the frigates' original operating systems (apart from missiles like the Harpoon and Evolved Sea Sparrow) were already

\footnotetext{
${ }^{64}$ Webb and Murray, Canada's hidden plan for predicted failure, 4-7; also confirmed in interviews: Confidential Source, Telephone interview with the Author, January 23, 2016.

${ }^{65}$ Confidential Source, Email interview with the Author, November 30, 2016.

${ }^{66}$ Confidential Source, Telephone interview with the Author, January 14, 2017.
} 
either Canadian or European in origin. Consequently, the HCM/FELEX project went with equipment produced in Canada, Israel, Sweden, Germany, and The Netherlands. ${ }^{67}$

Finally, to deal with the myriad of prime contractors and stand-alone projects incorporated in the HCM/FELEX, DND created a governance structure to oversee the project's executive-level decision-making, control costs, resolve disputes before they escalated, and provide a "continuity in key staff positions" ${ }^{68}$ This governance structure, known as the Committee of Sponsors, is said to be at the core of the modernization's success and was influenced by DND/CAF's experiences with the Maritime Helicopter Project. Senior defence officials did not want a repeat of the public airing of differences and disputes that saw the $\mathrm{CH}$ 148 'Cyclone' lurch from "crisis to crisis publicly [with] many big problems" not being resolved. ${ }^{69}$ The Committee was co-chaired by the Commander of the RCN and ADM (Mat) and included the ADM for Procurement at PWGSC and the Chief Executive Officers of Lockheed Martin Canada and the two shipyards, Seaspan and Irving. ${ }^{70}$ The Committee met quarterly and discussed the project's progress reports. It was at this table that problems and obstacles were dealt with and addressed. The Committee benefitted not just from its structure but also by the personalities involved; the key principals had a good relationship with one another. ${ }^{71}$ The positive rapport between key officials was evident at the project manager level as well. Problems were kept below the 'radar' and efforts were made to resolve issues and concerns. The strong

\footnotetext{
${ }^{67}$ Ibid.; Nicholas Tracy, Two-Edged Sword: The Navy as an Instrument of Canadian Foreign Policy (Montreal and Kingston: McGill-Queen's University Press, 2012), 403; Pugliese, David. "Canadian navy opts for non-American upgrade; Frigates to be modernized with other technology to avoid delays." Edmonton Journal, January 25, 2010, A4.

${ }^{68}$ Perry, 2015 Status Report, 36.

${ }^{69}$ Senior Government Official, Interview with the Author, September 25, 2016.

${ }^{70}$ Canada. Department of National Defence. Chief Review Services. Audit of the Halifax-Class Modernization/Frigate Life Extension (HCM/FELEX) Project (Ottawa: 2011).

${ }^{71}$ Pierre Lagueux, Telephone interview with the Author, September 27, 2016; Confidential Source, Telephone interview with the Author, January 27, 2017.
} 
relationships between parties can also be attributed to Lockheed's long history with the Halifaxclass; the firm manufactured the original combat systems in the frigates and had a longstanding association with DND/CAF officials on that and other projects (e.g. C-130J tactical airlift). ${ }^{72}$ Likewise, the shipyards themselves had performed maintenance work on the frigates and other naval vessels for decades. ${ }^{73}$ For these reasons when it comes to the HCM/FELEX the Committee is often singled out by commentators and insiders alike as a key variable in the project's success. ${ }^{74}$ (Its been said that the Committee provided the impetus for the National Shipbuilding Strategy governance structure detailed in Chapter Three. ${ }^{75}$ )

This does not mean that there were not challenges with DND/CAF's involvement in the $\mathrm{HCM} /$ FELEX. As will be detailed in the 'Industry' section below, during the revised project definition stage in 2008 there were disputes over the combat management system SOR. Likewise, when the original FELEX project definition was completed in 2005 it was envisioned that the modernized frigates would carry the $\mathrm{CH}-148$ Cyclone helicopters that had been ordered from Sikorsky in 2004. The Cyclones, which are larger than the storied CH-124 Sea Kings, required the helicopter platforms and hangars at the back of the frigates to be enlarged. The Maritime Helicopter Project's budget allocated \$282 million for these frigate modifications. However, successive technical-driven delays with the Cyclone pushed deliveries beyond the 2008 due date to 2015 , with full operating capability not expected until $2025 .{ }^{76}$ By the time it was realized that the Cyclones were not arriving on schedule, one frigate had already completed

\footnotetext{
${ }^{72}$ Confidential Source, Telephone interview with the Author, January 18, 2017.

${ }^{73}$ Confidential Source, Telephone interview with the Author, January 22, 2017.

${ }^{74}$ Senior Government Official, Interview with the Author, September 26, 2016.

${ }^{75}$ Ibid.

${ }^{76}$ Canada. Office of the Auditor General of Canada. Chapter 6 - Acquisition of Military Helicopters (Ottawa: 2010); Canada. National Defence and the Canadian Armed Forces. "CH-148 Cyclone procurement project." Accessed online July 9, 2017: http://www.forces.gc.ca/en/business-equipment/maritime-helicoper.page.
} 
the conversion. The HMCS Montreal was kept on as the "prototype ship" for testing the new helicopters. An additional two frigates, HMCS Halifax and HMCS Calgary, were later outfitted to carry the Cyclones. With most of the Halifax-class set to operate to at least 2036, another refit will be required for the remaining nine ships (to become Cyclone-capable lest the new helicopters remained land-based pending the arrival of the Canadian Surface Combatant ships). ${ }^{77}$ A constant concern throughout the project was personnel retention and skill erosion due to the reduction in sea time. The $\mathrm{RCN}$ implemented a risk mitigation strategy that involved sending some personnel to both allied "and like-minded navies" to "maintain and increase core naval skills and experience throughout" all ranks. ${ }^{78}$ Relatedly, removing much of the frigate fleet from service hampered naval readiness. By 2014 the RCN had fifteen of its thirty-three ships and submarines under refits or routine repairs. With its two AORs and two-thirds of it Iroquois destroyers facing decommissioning, National Defence and the CAF would have been hard pressed to respond had a major crisis or international incident occurred (e.g. the 1991 Gulf War or the 1995 Turbot War with Spain). ${ }^{79}$

PWGSC/IC: While the three other case studies examined in this dissertation witnessed delays from infighting between DND, PWGSC, and IC, the HCM/FELEX was, by all indications, not a victim of this. On the contrary, as one senior political official noted, "everyone was onboard" when it came to moving the project through the procurement process. ${ }^{80}$ The Committee of Sponsors discussed earlier featured PWGSC's ADM for Procurement as one of its key

\footnotetext{
${ }^{77}$ Confidential Source, Telephone interview with the Author, January 17, 2017; Pugliese, David. "Three frigates outfitted to take Cyclone helicopters." Ottawa Citizen, September 6, 2016.

${ }^{78}$ Canada. Department of National Defence. National Defence: 2012-2013 Report on Plans and Priorities (Ottawa: 2012), 31.

${ }^{79}$ Pugliese, David. "Half of Navy vessels under repair, refit: Fixes, modernization lead to 'most challenging' year for officials." Ottawa Citizen, April 21, 2014, A1.

${ }^{80}$ Senior PMO Official (ret'd.), Interview with the Author, December 10, 2016.
} 
principals. If there were issues related to the contracting process or the contracts themselves, they would have been dealt with there. For IC, its role was confined to ensuring that the prime contractors kept to their IRB obligations. The fact the Harper government committed to the 2001 federal shipbuilding policy and let DND and PWGSC run a competitive procurement process meant that that there were none of the offsets concerns raised in the HCM/FELEX as there had been in other projects such as the MSVS. ${ }^{81}$

\section{b. Industry}

As noted, there was not complete industry harmony on this project. In 2007 three bidders, were identified through a Solicitation of Interest Qualification proposal for the combat management system. One however eventually withdrew, leaving just General Dynamics Canada and Lockheed Martin Canada. General Dynamics Canada was initially in the running but pulled out in June 2008 when it concluded that it could not make enough profit because of "unviable commercial terms and conditions". In short, the risk transferred to the combat management system contract was deemed too much for General Dynamics, a view that was also shared by the Shipbuilding Association of Canada (who similarly complained that Ottawa was transferring "too much of the risk for contracts on the private sector"). ${ }^{82}$

Having said that, it is questionable whether any bidder could have scored more points than Lockheed Martin Canada. Lockheed had a long affiliation with the Halifax-class frigates. In the 1980s and 1990s, the company provided the original combat management systems in the frigates. Lockheed also had extensive experience providing in-service support contracts for both

\footnotetext{
${ }^{81}$ For a list of HCM/FELEX IRB obligations see: Canada. Industry Canada. "Procurement projects - Marine projects." Accessed online July 10, 2017: https://www.ic.gc.ca/eic/site/042.nsf/eng/h_00017.html\#marine.

${ }^{82}$ Chase, Steven. "Tory defence strategy runs into trouble." The Globe and Mail, June 3, 2008, A4.
} 
the Halifax-class frigates and Iroquois-class destroyers. ${ }^{83}$ Overall, Lockheed "had the know-how to do it" and by default had an edge on its competitors no matter how many bids had been submitted. Lockheed also had an incentive as the combat management system lead to get the contract completed on time and on budget, so as to situate themselves in good standing for future maintenance work and possible construction and installation work on the Canadian Surface Combatants. ${ }^{84}$ The need to avoid Washington's ITARs also possibly limited the number of other bidders on the project.

\section{c. Alliances and War}

The impact of the Afghanistan war and Canada's alliances on the HCM/FELEX was limited and generally indirect. For instance, as noted earlier, the uptake in Afghanistan-specific procurement projects in 2006-2007 partly influenced DND to merge the FELEX with the stand-alone technology and weapons projects so as to streamline the frigates' refit. Similarly, U.S. ITARs were bypassed to facilitate fewer problems with intellectual property issues at the border. Canada's alliance relationships did incentivize Maritime Command/RCN and DND officials in pushing through with the modernization project. For one, the experiences of allied navies in performing on littoral operations (supporting ground forces ashore with either ship-launched missile bombardments) or helping coordinate attacks in the Gulf War and the Balkans in the 1990s (especially the NATO conflict against Serbia in 1999), illustrated the need for Canada's frigates to have capabilities to interoperate with their predominantly U.S. Navy counterparts. Such lessons were reinforced in the 2011 NATO campaign against Libya. Without the

\footnotetext{
83 "Lockheed Martin Canada Satisfies Critical Design Review Milestone for Halifax Class Combat Systems." CNN. Accessed online September 9, 2016: http://money.cnn.com/news/newsfeeds/articles/marketwire/0650671.htm.

${ }^{84}$ Senior Government Official, Interview with the Author, September 26, 2016.
} 
modernization project, the navy would have faced "obsolescence" and become "marginalized in NATO, with a limited ability to contribute to coalition operations." 85

\section{Bringing It All Together}

The HCM/FELEX can be considered a success story if the project's starting point is the 2005 project definition stage. The project's slow start after identification in 2002 was due to the Chrétien and Martin governments' unwillingness to fund it until 2005, a delay of three years. However, from the point of the FELEX preliminary project approval in February 2005 onwards, the success of the project had more to do with the leadership and organizational strengths of DND and the Maritime Command/RCN and not with political executive involvement. In short, there was very little political involvement in the HCM/FELEX after 2005 because it was working well (which probably explains why the project was never incorporated into the National Shipbuilding Procurement Strategy in 2010) despite erroneous DND press releases to the contrary. ${ }^{86}$ As one former senior official framed it, "the worst thing you can do is mess around in something that is working". ${ }^{87}$ The Harper government committed to the Liberal 2001 shipbuilding industrial policy in 2006, (which may have increased the project's cost) and revised the preliminary project and effective project approvals in 2007-2008. Despite 2008 being an election year there are no indications that any of these actions contributed to delays.

The Harper government's 2007 budget cap of $\$ 4.3$ billion did lead to delaying other frigate upgrades to future dates, however, the cap itself represented a $\$ 1$ billion increase over the

\footnotetext{
${ }^{85}$ Canada. House of Commons. Standing Committee on National Defence. Evidence, $1^{\text {st }}$ session, $42^{\text {nd }}$ Parliament, Meeting No. 24, October 27, 2016.

${ }^{86}$ Pugliese, David. "Military slips up on shipbuilding history." Ottawa Citizen, January 5, 2016.

${ }^{87}$ Senior Government Official, Interview with the Author, September 23, 2016.
} 
earlier project budget. Moreover, the cap was effective in incentivizing $\mathrm{DND} / \mathrm{RCN}$ to prioritize the upgrades it needed to meet the operational demands it required the fleet to meet in the medium-term. That the budget cap was effective, as opposed to the first Joint Support Ship budget cap for example, is because it was realistic. A benefit of having a modernization project is that the parts and needed systems upgrades are already on the market. Many of these, like the Harpoon missiles and $57 \mathrm{~mm}$ naval guns, are non-developmental Military-Off-The-Shelf (MOTS) products. Similarly, modernizing an existing capability can be easier for pricing labour costs - fifteen years of routine maintenance on the Halifax-class left both industry and DND knowledgeable about the ships' workings. ${ }^{88}$ In the context of bureaucratic politics, the budget represents a compromise solution between a government willing to fund the HCM/FELEX (and the armed forces generally) up to a point, and DND/CAF wanting to acquire as many new upgrades to the ships as possible.

A realistic, properly accounted budget was not the only driver of success in the project. The three problem case studies in this dissertation all featured a classic bureaucratic politics dilemma for a Westminster system: the absence of clear direction from the political executive as to the purpose of a procurement project. This lack of clarity led the organizational interests of DND/CAF, PWGSC and IC to dominate and contributed to delays because of a failure in achieving consensus. With the HCM/FELEX such bureaucratic in-fighting was averted due to the Committee of Sponsors governance structure. The Committee allowed for an airing of grievances and a resolution of disputes with the combined leadership of departments and industry partners. It also permitted the building of trust between principal actors. Of course,

\footnotetext{
${ }^{88}$ Subject Matter Expert, Interview with the Author, October 5, 2016; Confidential Source, Interview with the Author, January 22, 2017.
} 
overlaying the entire project was a realization by bureaucratic and political actors alike that the HCM/FELEX was a 'no fail' procurement for the armed forces. A setback in the modernization of what became the RCN's only surface combat ships after 2017 would have negatively impacted Canada's alliance commitments and deprived the federal government of an asset necessary for meeting its foreign policy objectives in North America (e.g. Arctic summer sovereignty exercises) and globally. Pointedly, this clear direction did not come from the political executive but from DND and the navy. By all accounts, the necessity of modernizing the frigates was understood across the federal government.

Although the governance model was key to the relative success of this project, there are doubts as to its replicability. The Committee of Sponsors was a very time intensive effort on the part of its principals, which raises questions as to how feasible this model would be for every MCP. A similar structure was adopted for the National Shipbuilding Procurement Strategy (NSPS). However, it is not completely clear that beyond picking shipyards that this governance model has been effective in preventing delays in any number of the of NSPS shipbuilding projects. To quote one official, the Committee worked "because it existed for that project" alone. ${ }^{89}$

Finally, in looking at the other exogenous variables, delays were avoided with respect to Canada's U.S. allies by DND's requirement that Lockheed Martin Canada avoid the ITARs. The purchase of non-American equipment and software likely assisted in circumventing the delays associated with past U.S. purchases, albeit this is challenging to prove. Still, concerning the impact of Canada's international relations on the project, Maritime Command/RCN's role in

\footnotetext{
${ }^{89}$ Subject Matter Expert, Interview with the Author, October 5, 2016.
} 
alliance operations did contribute to the need for a timely and efficient modernization of the frigates lest Canada become deficient in its obligations to NATO. The sudden but not unforeseeable loss of the Protecteur-class AORs in 2014-15, after years of 'wear and tear' demonstrated how a procurement delay for a crucial naval capability can hamper the RCN's overall capacity and capability to fulfill government and alliance responsibilities. As Chapter Three noted, the loss of the AORs forced the RCN into several interim solutions, including renting allied ships and converting a container ship to bridge the capability gap until new, permanent replacements could arrive.

When it comes to industry, there are no discernable significant delays brought about by industry pressure. There was, however, a small delay in the summer of 2008 over complaints by General Dynamics on the matter of DND transferring too much risk to the contractors. But as indicated, any would-be bidder in the combat management system RFP faced challenging odds from Lockheed Martin Canada as a competitor (or contender). 


\section{Chapter 7 - Conclusion}

The following sections reiterate the research question and hypothesis before summarising the dissertation's key findings. Attention is also paid to the dissertation's contribution to Canadian defence procurement literature, policy implications and areas for future research.

\section{Research Question and Hypothesis}

The research question posed in this dissertation was: 'how can we account for delays in Canada's defence procurement program?' The hypothesis tested was that the political executive is central to understanding why there are delays in Canada's current procurement program. The hypothesis was applied to the time period of 2006-2015 when the Conservative government of Stephen Harper held power and initiated the largest defence build-up in decades before implementing defence budgetary cuts in reaction to the 2008-2009 global recession. The Liberal governments of Jean Chrétien and Paul Martin were analyzed as well, for two reasons: First, all four case studies trace their origins back before the Harper government took power in 2006. Secondly, the role of these governments, however briefly examined, provides additional comparative context to the dissertation's hypothesis on the role of the political executive. This dissertation defined delays as occurring when a Major Crown Project did not meet its originally planned project milestone dates that are established after it is officially identified by DND as a sought-after capability. The prime minister, the cabinet and their political advisors comprise the 'political executive' and in defence procurement literature are generally viewed as ancillary to the procurement system. In contrast, this dissertation argued that the political executive is where key high-level decisions are made concerning defence procurement. 
Three independent, exogenous variables were identified as possible explanations for causing delays: 1) the defence procurement bureaucracy (chiefly, the involvement of the three departments primarily involved in defence procurement: DND, PWGSC, IC); 2) the defence industry (e.g. lobbying government on particular points); and, 3) Canada's military alliances and its involvement in the Afghanistan war (2001-2014). Each of the four case studies contained separate sections for the hypothesis and the three independent variables. Within each section, explanation and analysis was given on the role, if any, played by each independent variable in causing a delay in three case studies: 1) The Joint Support Ships, 2) the Medium Support Vehicle System - Standard Military Pattern trucks, and 3) the Fixed-Wing Search and Rescue aircraft. A fourth case study, the Halifax-class Modernization/Frigate Life Extension, used the same analytical framework to determine if the political executive was responsible for a MCP not being delayed.

\section{Summary of Findings}

In answering this dissertation's research question, the role of the political executive in being responsible for procurement delays results in a hypothesis not completely proven for the case studies in question. The political executive can only partly explain why there are delays in Canadian defence procurement. In each of the four case studies at least one or more of the three exogenous independent variables also played a role in contributing to delays or, as with the fourth case study (the HCM/FELEX), better accounted for why significant delays did not occur. The results of this dissertation's research demonstrate that procurement delays are the result of the overlapping connection between the decisions of the political executive and the three 
independent, exogenous variables (especially the bureaucracy). This interconnection was demonstrated throughout each of the four case studies.

In the three case studies that have been characterised by delays (JSS, SMP, and FWSAR), those delays occurred in the project definition stage, after which: 1) the project has been identified by DND; 2) the SOR is written; 3 ) the estimated budget (or Rough Order Magnitude costs) is established; 4) cabinet approval is obtained at a policy-relevant cabinet committee (if needed); and 5) Treasury Board has allocated Preliminary Project Approval funding to create a project management office. In none of these cases did the political executive cause delays in the project definition stage by intervening. (The FWSAR was halted by the ministers of National Defence, PWGSC, and IC in 2009 over departmental-infighting and allegations of a 'rigged' SOR but this partly stemmed from earlier political decisions.) Hence, the political executive's contribution to procurement delays are primarily the product of policy decisions taken before project definition. Budget decisions are important in determining whether a project is delayed or not, but only to a point.

In Atkinson's and Nossal's study of the CF-18 procurement in 1979-1980 (identified in Chapter One), that project's success in avoiding delays to the policy decisions taken by the political executive early in the procurement process. These policy decisions concerned defining the 'New Fighter Aircraft's' purpose, fleet size, roles, and requiring that an inter-departmental governance structure be used for project management. Budget caps were similarly put in place as a constraint on ambition so as to avoid 'gold plating' the SOR. ${ }^{1}$ These policy decisions represented political executive directions and established parameters that contained what would

\footnotetext{
${ }^{1}$ Atkinson, Michael M. and Kim Richard Nossal. "Bureaucratic politics and the new fighter aircraft decision." Canadian Public Administration 24, no. 4 (1981): 531-558.
} 
otherwise be a typical case of bureaucratic politics conflict: organizations and actors stick to their mandates and attempt to advance their own interests which, in a multi-department procurement system like Canada's, is a recipe for gridlock as each organization has a veto on whether a MCP is ready to go before Treasury Board for Effective Project Approval for contract award.

The FWSAR and MSVS-SMP both suffered from a lack of clarity as to their roles and, in the case of the former, fleet size. For the FWSAR project, neither the Martin or Harper governments' defence policies provided clarity as to what the aircraft were supposed to do: was it simply to undertake search and rescue missions or was it to also act a transport aircraft something that the RCAF wanted with the 'Baby Herc' C-27J? Consequently, the RCAF filled the policy vacuum void with its own interests, writing the SOR in a way that created a fake competition, and generating opposition from PWGSC and IC, which produced deadlock. It took political executive involvement to halt the process in 2009 , bring in an independent third party (the National Research Council) and establish a multi-departmental governance structure, the FWSAR Secretariat, to bridge the competing interests. Clarity was eventually provided to roles and purpose, and over the course of 2011-2016, a new process was started and a contract awarded in December 2016.

The SMP had a similar experience: there was no governance model in place. The Martin government did establish a policy framework that outlined roles and purpose for the medium logistics trucks (e.g. be capable of transport in a C-130), however, the Harper government in its 2006 announcement of the SMP provided no such clarity and actually added greater confusion by acquiring transport aircraft larger than the C-130s, the C-17s. Like its air force counterparts, the army filled the policy void, increasing the scope and size of the trucks to the point where there was infighting between DND and the army over what exactly the term 'medium' entailed. 
The absence of a governance model led to disputes with PWGSC and TBS, especially once it became known that money had been reallocated from the LVM project to the SMP without PWGSC's or TBS's knowledge. The result was a cancelled RFP in 2012 and a restart - a position that was supported by the Prime Minister's Office. In contrast, the same June 2006 announcement as the SMP featured a successful truck acquisition: the army reserves' MilCOTS trucks. These vehicles had a clearly defined role and purpose (domestic-only operations, off-theshelf commercial truck) and a realistic budget; hence, why they were acquired relatively quickly. It would appear that the absence of a multi-departmental governance structure for the MilCOTS was not necessary, given that it was a comparatively less costly project, had clearly defined requirements, and was less technically complex.

The JSS, however, differs from the FWSAR and SMP projects in that delays found in this project are the result of two policies working at cross-purposes. The 2001 shipbuilding policy, adopted by Harper government in 2006-2007 and encapsulated in PWGSC's Supply Manual and reflected in the NSPS (renamed the National Shipbuilding Strategy by the Justin Trudeau government), stipulates that federal ships over 1,000 tonnes are to be built in Canada, using shipyards selected on the basis of a competitive process. This policy ruled out alternative overseas builds for the JSS, as the UK and Norway have done for their new AOR ships (both countries have ordered vessels from South Korea). The primary goal of the project is job creation and supporting the shipbuilding industry, not delivering military capability. In the first iteration of the JSS, the project had policy guidance in the form of the 2005 Defence Policy Statement which identified the ships' purpose, roles, and fleet size. A budget was established in 2004 that was seen by both CAF and government alike as sufficient to acquire three Joint Support Ships. The Conservatives may have emphasized the ships' contributions to industry but they largely 
kept to the project's capability goals upon taking power in 2006. The restart of the JSS in 2010 still came with specific parameters on roles, fleet size, and purpose (albeit scaled back from 2004-2008) and a budget cap. But in both versions of the project, delays were the result of the requirement to build the ships in Canada; simply put, Canada's shipyards remained woefully unprepared to undertake the building of a complex ship like the JSS. It is possible that the NSPS will establish a viable shipbuilding sector that makes domestic shipbuilding a prudent option, but it is telling that even with a proven off-the-shelf design (in which Intellectual Property issues created delays) the Seaspan yard remained unable to develop the capacity necessary to build these two ships without millions in additional federal aid.

Delays in one project can impact the progress of another. The $\mathrm{CH}-148$ Cyclone missed its first delivery date in 2008 (it is years behind schedule) which impacted the HCM/FELEX project's plans to retrofit the frigates to carry the larger Cyclone instead of the older Sea King. That refit, which was already completed on one ship, will now have to take place at some point in the future, thus costing the taxpayer more and undermining the navy's operational readiness. However, the political executive can also impact the progress on one project even if it acquires another in a timely manner: For example, the purchase of four C-17s in 2007 impacted Land Force Command's planned scope for the SMP. Under the Martin government, the new medium logistics trucks were to be designed to be carried in the relatively smaller C-130J tactical airlift; the much larger $\mathrm{C}-17 \mathrm{~s}$ (a Harper campaign promise) sidelined that planning and encouraged army planners to push for a larger truck.

Defence industry lobbying remains an important independent variable: procurement is exempt from international treaties and therefor allows for protectionist policies. That there are few major defence industry companies left in Canada, or indeed among the country's Western 
allies, means that procurement contracts are going to be a source of industry pressure. Aside from the U.S., most Western countries like Canada buy intermittently due to the cost of advanced military technology; consequently, a typical defence acquisition is expected to last for decades. The JSS and HCM/FELEX faced less lobbying than the SMP and FWSAR because the 2001 shipbuilding policy already determined that the shipbuilding and maintenance would take place in Canadian shipyards - a policy that was reinforced under the NSPS in 2010. The FWSAR and the SMP, however, represented possible lucrative contracts for Canada's few remaining businesses capable of producing such equipment. In the end, the technical complexity of the requirements for each project weeded out any serious domestic competition but still did not settle industry debate for the losers in these two projects challenged PWGSC's process at the CITT.

Lastly, Canada's alliances mattered the most in the cases of the HCM/FELEX and SMP. With the SMP, the Canadian Army's experiences in combating roadside bombs and Taliban small arms fire brought home the realization that the SMPs needed armor, which led to cost increases and delays as more time was spent changing the project's requirements. As Canada deploys its armed forces overseas alongside its allies in coalitions, the demand for missionspecific equipment will likely not be specific to Canada alone. The SMP project illustrated how Canada's interest in getting new, bigger, durable trucks coincided with its allies doing the same. The HCM/FELEX was seen as a 'no fail' project by political, military, bureaucratic, and industry participants alike. This sense of urgency was partly driven by the fact that the Halifax-class frigates were the core of the navy's combat surface fleet and necessary for the navy to meet domestic and alliance maritime security objectives. Furthermore, the longstanding need to be interoperable with NATO ensured that the project could avoid U.S. ITARs and possibly delays by relying on technology and software from European firms. 


\section{Contributions to the Literature}

This dissertation contributes to the scholarly literature on Canadian defence procurement by addressing a longstanding assumption that the political executive is responsible for delays. This dissertation has now provided the first scholarly analysis on this institution and its role in the defence procurement system. Second, this dissertation provides the first in-depth, comparative study of multiple Canadian defence procurement case studies since Haglund's edited 1988 volume, Canada's Defence Industrial Base. Canadian procurement scholarship overall has largely been confined to short, one-off case studies, or surveys of the procurement landscape except for Plamondon's Sea King replacement study and Nossal's overview of procurement system history and possible solutions for fixing it.

Additionally, Chapter Two of this dissertation has provided an in-depth examination of the defence procurement system and the stages involved in moving a MCP from identification to project close-out. Davies and Williams have provided such overviews, too, but this dissertation goes further by situating the procurement system and process within the larger context of defence policy external and internal influences. In this context, this dissertation complements the work of Nossal in Charlie Foxtrot and Sloan and Perry in their respective annual procurement update reports for the Canadian Global Affairs Institute.

This dissertation has also demonstrated that the Bureaucratic politics model still represents an effective framework for understanding both procurement failures and successes. The multi-departmental nature of the procurement system still poses a significant challenge to ensuring MCPs are delivered in a timely manner and within budget. Outside of a handful of case studies identified in the literature review, the Bureaucratic politics model remains underutilized in accounting for problems in Canada's procurement system. 
Finally, this dissertation has provided the first thorough case study examination of either the HCM/FELEX or MSVS projects. These projects have only received brief mentions in thinktank surveys and internal DND audits, yet both represent significant examples of a successful and delayed project. Consequently, as the Trudeau government proceeds with the $\$ 62$ billion purchase of 15 Canadian Surface Combatants perhaps there are lessons learned from the HCM/FELEX that can feed into discussions on these warships. ${ }^{2}$

\section{Policy Implications}

There are several policy implications that emerge from this dissertation. The first is to recognize how pertinent this dissertation's research topic remains in the study of Canadian defence procurement. Between 2015 and 2018, two new procurement projects - the Interim AOR ship from Davie Shipyard in Quebec, and the purchase of eighteen used Australian F-18s by the Justin Trudeau government - have shed light on how political executive involvement in defence procurement is still very much a topical subject. ${ }^{3}$ In saying this, a policy implication that stands out in this dissertation is acknowledging that no government starts with a clean slate in defence procurement and none seem inclined to want to learn the lessons of their predecessors. The FWSAR project and Air Command's favouring of the C-27J was the subject of intense lobbying and bureaucratic opposition in 2004-2005 when it was defeated at the Martin cabinet table. The Harper Conservatives, after not taking action on the FWSAR during their first two years in

\footnotetext{
${ }^{2}$ Canada. Department of National Defence. Strong, Secure, Engaged: Canada's Defence Policy (Ottawa: 2017).

${ }^{3}$ Cudmore, James. "Davie Shipyard's $\$ 700 \mathrm{M}$ deal for navy supply ship retrofit to go ahead." CBC News. Accessed online July 17, 2017: http://www.cbc.ca/news/politics/davie-shipyard-s-700m-deal-for-navy-supply-ship-retrofit-togo-ahead-1.3344037; Gillies, Rob. "Canada to buy used Australian jets over new Boeing aircraft." Financial Post. Accessed online January 8, 2018: http://business.financialpost.com/pmn/business-pmn/canada-to-buy-usedaustralian-fighter-jets
} 
office, recommitted to the project without having addressed the underlying reasons for its failure in the previous government: a SOR that favoured the C-27J. The Justin Trudeau government has found itself in a similar situation after pledging to not sole-sole purchase a replacement for the CF-18s and buy the F-35. They have in fact done just that and are boxed into a situation where they will buy used Australian F-18s, with little justifiable policy rationale, and even possibly F35s should they adhere to the promise of an open competition in $2019 .{ }^{4}$ Consequently, one possibility to help decrease the level of 'politicking' between governments over defence procurement projects is to introduce a bipartisan joint standing committee on defence procurement, as recommended by Nossal in 2016. The Harper era may represent an anomaly in what historically has been largely a shared understanding between the two governing parties on Canada's place in the world and the defence needs facing the country (the NDP, Greens and Bloc Québécois have never bought into this consensus). The bipartisan support between the Liberals and Conservatives in the post-Harper era on the Canada-U.S. defence and trading relationship and NATO operations in Eastern Europe, respectively, would suggest a return to this previous longstanding consensus. As Nossal notes, a "joint parliamentary committee model would provide an unparalleled opportunity to maximize bipartisanship" given the diverse mix of experiences found among Independent and Conservative Senators, and the 280-plus Liberal and Conservative MPs in the House of Commons. The goal of such a committee would be to set strategic goals within the agreed upon parameters of the country's defence policy. This way, the strategic rationale for certain MCPs initiated under one government, like the Joint Support Ships or a new fighter jet replacement, would have the necessary political buy-in already in place for when a

\footnotetext{
${ }^{4}$ McDonough, David and Brian Lee Crowley. Interim Super Hornet Survey Project (Ottawa: Macdonald-Laurier Institute, 2017).
} 
new government takes power. ${ }^{5}$ Already, Australia, a country known for its bi-partisan consensus on major defence and foreign policy issues, has such a committee model in place with its Joint Committee on Foreign Affairs, Defence and Trade. ${ }^{6}$

Secondly, this dissertation highlights the role of the government's competition requirement (embedded in the Contracting Policy) as a source of delays. In short, processes have to be built for every MCP that is not outright identified as a sole source. In the case of the MSVS-SMP there were just two bidders; for the second iteration of the JSS, the contract award design featured just one bidder. Likewise, for the HCM/FELEX project there was just one bidder for the combat management system, the most expensive aspect of the project. FWSAR was an outlier compared to these other projects with three bidders, but even there, only two were ever serious contenders. The premise of the competitive approach to MCP contracting is that it leads to lower costs and possibly better offsets, however, in defence procurement there are only a handful of major defence contractors in the world. A generic competitive model makes sense when buying photocopiers, but less so for multi-billion dollar defence equipment. Interoperability with Canada's allies practically ensures that purchases will originate from European or American producers, of which there are only a handful; the result of industry consolidation in the 1990s. ${ }^{7}$ The amount of time spent writing a SOR and building a competitive process so that as many companies as possible can bid needs to be re-examined in light of the changed global defence marketplace. Continued emphasis on early and consistent industry engagement is thus necessary if the competitive model is to remain. At the very least, project

\footnotetext{
${ }^{5}$ Nossal, Charlie Foxtrot, 156-164.

${ }^{6}$ McGuinness, Kieran and Greg Austin. "Defence bipartisanship: holy grail or poisoned chalice?" Australian Strategic Policy Institute: The Strategist. Accessed online July 14, 2017: https://www.aspistrategist.org.au/defencebipartisanship-holy-grail-poisoned-chalice/.

${ }^{7}$ Edgar, Alistair David and David Haglund. The Canadian Defence Industry in the New Global Environment (Montreal-Kingston: McGill-Queen's University Press, 1995).
} 
budgets need to be grounded on realistic, costed budgets obtained early in the procurement process from continuous industry consultation.

Finally, the dissertation draws attention to the idea of creating a separate procurement agency. As the literature review indicates, this suggestion has been the subject of both scholarly and government recommendations. Its creation would represent a return to a model Canada had in place up to 1969 when the Department of Defence Production was phased out after the 1962 Royal Commission on Government Organization ('Glassco Commission') recommended the creation of a one contracting agency to serve all federal departments, the Department of Supply and Services (now PSPC). ${ }^{8}$ There was some pushback on the single agency model by interviewees too; with one remarking that the model was not a complete success in Australia and that very nature of shared accountabilities in Canada's cabinet system complicates the idea of a single point of accountability. ${ }^{9}$ However, it is an idea worth considering. A separate procurement agency comprising the relevant defence procurement functions of DND/CAF, PSPC and ISEDC, with its own minister, backed with a defence industrial policy to facilitate relationships with industry, would simultaneously remove the challenge of inter-departmental strife while providing both a governance structure, a source of procurement expertise, and an accountable Minister of the Crown who would have to be the face and voice of military procurement at the cabinet table, in the House of Commons and in the public. To help address issues of staff turnover and retention, a new human resources structure could be introduced to ensure that as much institutional knowledge is retained within the agency as possible. Separate procurement

\footnotetext{
${ }^{8}$ Canada. Library of Parliament - Parliamentary Information and Research Service. The Evolution of Defence Procurement in Canada.

${ }^{9}$ Confidential interview with a former senior government official, Ottawa, September 26, 2016.
} 
classifications within the federal civil service and CAF could enable this structure. ${ }^{10}$ It is worth noting that during the Harper government the idea of moving towards a separate procurement agency was considered at one point. Under ministerial orders in 2013, ADMs Dan Ross and Tom Ring appointed senior civil servants in their respective departments, DND and PWGSC, to examine organizational reforms for defence procurement. An estimated 18 models were examined but agreement was never obtained due to personality differences and a 'zero-sum' view over the possible loss of competing departmental mandates in the event of a new agency being created. ${ }^{11}$

\section{Future Research}

Five key areas of future research emerged from this dissertation. The first includes the need to evaluate the role of minority versus majority governments in Canadian defence procurement. The policy challenges with the Harper government started in its first term, in a minority parliament when, as a new government that distinguished itself from its predecessors on defence, committed to multiple fleet recapitalizations. In contrast, few MCPs were initiated during its one majority term, 2011-2015 (largely for fiscal reasons). The election of a majority Liberal government under Justin Trudeau in 2015, with its commitment to more defence spending in the 2017 budget thus presents a current comparative case study worth examining.

Second, more research is needed on the role of defence industry lobbying, especially in light of the FWSAR project. Historical case studies (e.g. the Canadian Patrol Frigate program in the

\footnotetext{
${ }^{10}$ Confidential Source, Telephone interview with the Author, January 23, 2017.

${ }^{11}$ Confidential Source, Telephone interview with the Author, February 16, 2017; Personal animosity between ADMs Ross and Ring was confirmed by other interviewers as well: Confidential Source, Telephone interview with the Author, January 5, 2017.
} 
1980s or the CF-18 acquisition in 1979-1980) illustrate the influence of industry in shaping the procurement system and outcome; however, an update is required. Another related topic is the connection between defence industry lobbying and regionalism. The jockeying between firms in Quebec and Nova Scotia over the Interim AOR has made it clear that even in an age of ITBs and a well-structured procurement process, regionalism has not completely gone away as a factor in Canadian defence procurement.

Third, although defence policy has a low profile among the Canadian electorate, the Liberals and Conservatives do make some procurement commitments on the campaign trail (usually to embarrass each other). However, a future project should examine if such commitments are carried out (e.g. interim fighter jets, strategic airlift) and, if so, whether they pose more problems for $\mathrm{DND} / \mathrm{CAF}$ because of planning implications and resource constraints. For example, the C$17 \mathrm{~s}$ were a Conservative campaign promise in 2005-2006, even though they were not a part of DND's Investment Plans. As this dissertation showed, the introduction of the C-17s caused a ripple effect in the FWSAR and SMP projects.

Fourth, occasionally the political executive fast-tracks a procurement project that was not a campaign promise or a part of the any official defence policy White Paper or statement. In the last year of the Harper government, two such projects - the purchase of a fifth C-17 and a contract for the Interim AOR - were approved relatively quickly in comparison to other MCPs. A question here is whether electoral calculations played a role in the political executive's favouring of these projects (a failed attempt to acquire a Mistral Class amphibious ship by the Harper government in its last year in office represents another case study to include in that research 
area). ${ }^{12}$ And lastly, Paul Greener's study on New Zealand defence procurement decision-making illustrated how alliance politics (with Australia) and defence's low-level priority among New Zealanders shaped procurement outcomes in that country. While Canada is regularly compared to Australia, a comparative study with New Zealand on how geopolitics and domestic pressures shape procurement decisions would be welcomed.

\footnotetext{
${ }^{12}$ The Canadian Press. "Ottawa's backroom bid for French helicopter ships sidelined by election." CBC News, September 20, 2015. Accessible online: http://www.cbc.ca/news/politics/canada-election-2015-backroom-bidfrench-ships-election-1.3235816.
} 


\section{Bibliography}

\section{Sources}

"Auditor general plans to review defence sole-source contracts." Prince George Citizen, November 28, 2007.

“Canada looks for search planes.” The Times \& Transcript, January 8, 2013, C3.

“Canadian navy boards ship carrying military supplies." The Independent, August 3, 2000. Accessed online September 2, 2016:

http://www.independent.co.uk/news/world/americas/canadian-navy-boards-ship-carryingmilitary-supplies-711281.html.

"Canadian Solution Selected by the Armada de Chile for Frigate Combat Management System Replacement Program.” Lockheed Martin Canada. Accessed online July 6, 2017:

http://www.lockheedmartin.com/ca/news/2016/canadian-solution-selected-by-the-armada-dechile-for-frigate-co.html.

"Election would stall new planes." The Edmonton Journal, November 16, 2005, A5.

"Lockheed Martin Canada Satisfies Critical Design Review Milestone for Halifax Class Combat Systems." CNN. Accessed online September 9, 2016:

http://money.cnn.com/news/newsfeeds/articles/marketwire/0650671.htm.

“Rescue aircraft inadequate.” Times Colonist, September 20, 2014, A14.

"Tanks for the Lesson: Leopards, too, for Canada." Defense Industry Daily. Accessed online June 27, 2017: http://www.defenseindustrydaily.com/tanks-for-the-lesson-leopards-too-forcanada-03208/.

"The CF18 Incremental Modernization Program", Canadian-American Strategic Review (December 2003). Accessed online August 12, 2016: http://www.casr.ca/id-cf18-3-1.html.

“The Joint Support Ship Project," Defense-Aerospace.com. Accessed online July 15, 2017:

http://www.defense-aerospace.com/article-view/release/37340/canada-details-new-joint-supportships-(apr.-19).html.

Adams, Robert Michael. "Procurement Maketh Policy: A Case Study of The CP-140 Aurora and The Leopard I” (MA Dissertation, McMaster University, 1980). 
Allison, Graham and Philip Zelikow. Essence of Decision: Explaining the Cuban Missile Crisis (2 ed.). New York: Addison Wesley Longman, 1999.

Arseneault, J.W. "The DDH 280 Program: A Case Study of Governmental Expenditure Decision-Making," in Canada's Defence Industrial Base, ed. David G. Haglund (Kingston: Ronald P. Frye \& Company, 1988).

Atkinson, Michael M. and Kim Richard Nossal, "Bureaucratic politics and the new fighter aircraft decision," Canadian Public Administration 24, no. 4 (1981).

Barry, Donald and Duane Bratt, "Defense Against Help: Explaining Canada-U.S. Security Relations," American Review of Canadian Studies 38, No. 1 (2008).

Bercuson, David J., Aaron P. Plamondon, and Ray Szeto. An Opaque Window: An Overview of Some Commitments Made by the Government of Canada Regarding the Department of National Defence and the Canadian Forces: 1 January 2000 - 31 December 2004 (Calgary: Canadian Defence and Foreign Affairs Institute, 2006).

Berkok, Ugurhan. "Canadian defence procurement", in Defence Procurement and Industry Policy: A small country perspective, eds. Stefan Markowski, Peter Hall and Robert Wylie (New York: Routledge, 2010).

Blanchfield, Mike. " $\$ 12$ billion in new aircraft needed now: defence chief." Ottawa Citizen, November 12, 2005, A3.

Blanchfield, Mike. " $\$ 60 \mathrm{~B}$ in defence spending rolls on despite recession.” Edmonton Journal, May 28, 2009.

Blanchfield, Mike. "Air force chief defends \$3B plan for new aircraft." Ottawa Citizen, March 28, 2009, A5.

Blanchfield, Mike. “Air force gives firm's sales pitch short shrift.” Ottawa Citizen, June 6, 2005, A1.

Blanchfield, Mike. "Big Issues: Defence and Foreign Affairs - the four main parties have differing views about defending Canada.” Edmonton Journal, January 12, 2006.

Blanchfield, Mike. "Conservatives shut down key Afghan cabinet committee," Globe and Mail, January 5, 2011.

Blanchfield, Mike. "Hercules, Buffalo could fly into history: Military makes case for \$200M program to replace ancient search, rescue aircraft." Ottawa Citizen, February 10, 2004, A1. 
Blanchfield, Mike. "Military strategy for cabinet's eyes only." Ottawa Citizen, May 15, 2008.

Blanchfield, Mike. "No income tax for soldiers in danger zones: New search-and-rescue planes top tiny list of new defence expenditures." Ottawa Citizen, March 24, 2004.

Bland, Douglas L. Commission of Inquiry into the Deployment of Canadian Forces to Somalia. National Defence Headquarters: Centre for Decision (Ottawa: 1997).

Bland, Douglas L., ed., Canada without Armed Forces? (Montreal: McGill-Queen's University Press, 2004).

Bland, Douglas. "Canada and Military Coalitions: Where, How, and with Whom?", Institute for Research on Public Policy. Policy Matters 3, no. 3 (2002).

Brewster, Murray. "Air force pushed for new plane despite budget axe." Prince George Citizen, May 27, 2014, A8.

Brewster, Murray. "New planes high on Liberal agenda." Ottawa Citizen, December 16, 2015, A11.

Brewster, Murray. "Old rescue planes won't be retired for several years." The Daily Gleaner, April 14, 2008, A6.

Brewster, Murray. "Upgrading frigate air conditioning will cost navy $\$ 50$ million." CBC News. Accessed online July 9, 2017: http://www.cbc.ca/news/politics/frigate-air-conditioning1.3933418 .

Byers, Michael and Stewart Webb, Blank Cheque: National Shipbuilding Procurement Strategy Puts Canadians At Risk Ottawa: Rideau Institute/Canadian Centre for Policy Alternatives, 2013).

Byers, Michael and Stewart Webb, Search and Rescue: The Case for a Made-in-Canada FixedWing Search and Rescue Fleet (Ottawa: Rideau Institute/Canadian Centre for Policy Alternatives, 2012).

Byers, Michael. "Needed: A big yellow plane that can hang from the sky." National Post, March 13, 2012, A12.

Byers, Michael. "Why Canada's search for an icebreaker is an Arctic embarrassment." Globe and Mail, January 21, 2014.

Canada, Department of National Defence and the Canadian Armed Forces. Internal Audit of Medium Support Vehicle System (MSVS) Project (Ottawa: 2014). 
Canada, Department of National Defence. "Halifax Class Modernization/Frigate Life Extension (HCM/FELEX).” Major Crown Projects: 2006-2007 (2006);

Canada. Canadian International Trade Tribunal. Oshkosh Defense Canada Inc. v. Department of Public Works and Government Services, File Nos. PR-2015-051 and PR-2015-067 (Ottawa: 2016).

Canada. Department of Finance Canada. The Budget Plan 2004.

Canada. Department of Finance Canada. The Budget Plan 2005.

Canada. Department of Finance. The Budget Plan 2005 (Ottawa: 2005), 220.

Canada. Department of National Defence and the Canadian Armed Forces. DND News Release. “"Canada First' Defence Purchases - A Commitment to Canadians”, June 29, 2006.

Canada. Department of National Defence and the Canadian Armed Forces. DND News Release. “"Canada First' Defence Purchases - Joint Support Ship”, June 26, 2006.

Canada. Department of National Defence and the Canadian Armed Forces. "Medium Support Vehicle System Project." Accessed online June 25, 2017: http://www.forces.gc.ca/en/businessequipment/medium-support-vehicle.page.

Canada. Department of National Defence and the Canadian Armed Forces. "National Defence: 2015-2016 Report on Plans and Priorities" (Ottawa: 2015).

Canada. Department of National Defence and the Canadian Armed Forces. "Royal Canadian Air Force: Aircraft." Accessed online June 26, 2017: http://www.rcafarc.forces.gc.ca/en/aircraft.page.

Canada. Department of National Defence, "Canadian Armed Forces Bases, Wings and Selected Installations and Sites Across Canada", Reports on Plans and Priorities 2013-14 (Ottawa: 2013).

Canada. Department of National Defence, "Government of Canada Awards Major Military Procurement Contracts for New Trucks". Accessed online February 16, 2017. http://news.gc.ca/web/article-en.do?nid=1001579.

Canada. Department of National Defence, "Joint Support Ships to be renamed Protecteur and Preserver". Accessed November 1, 2017: http://www.navy-marine.forces.gc.ca/en/newsoperations/news-view.page?doc=joint-support-ships-to-be-renamed-protecteur-andpreserver/j7oyseor 
Canada. Department of National Defence, 2006-2007 Report on Plans and Priorities. Ottawa: 2006.

Canada. Department of National Defence, Department of National Defence: 2003-2004 Report on Plans and Priorities: Status Report on Key Capital Projects (Ottawa: 2003).

Canada. Department of National Defence, Report on Transformation 2011. Ottawa: 2011.

Canada. Department of National Defence. "Canada First" Defence Strategy Procurement." Accessed online February 13, 2017: http://www.forces.gc.ca/en/news/article.page?doc=canadafirst-defence-strategy-procurement/hnocfo8n.

Canada. Department of National Defence. "Frigate Life Extension (FELEX)." Major Crown Projects: 2007-2008 (2007).

Canada. Department of National Defence. "Halifax Class Modernization/Frigate Life Extension (HCM/FELEX)”, Major Crown Projects: 2009-2010 (2009).

Canada. Department of National Defence. "Halifax-Class Modernization (HCM) / Frigate Life Extension (FELEX).” Backgrounder, November 24, 2014. Accessible online:

http://www.forces.gc.ca/en/news/article.page?doc=halifax-class-modernization-hcm-frigate-lifeextension-felex/hkm9beb0

Canada. Department of National Defence. "Medium Support Vehicle Project (MSVS)", 2011 2012 Status on Major Crown Projects.

Canada. Department of National Defence. "Medium Support Vehicle Project (MSVS)", 20092010 Status on Major Crown Projects.

Canada. Department of National Defence. "Medium Support Vehicle Project (MSVS)", 20122013 Status on Major Crown Projects.

Canada. Department of National Defence. 1994 White Paper on Defence (Ottawa: Department of National Defence, 1994).

Canada. Department of National Defence. 2013-2014 Report on Plans and Priorities.

Canada. Department of National Defence. 2015-2016 Report on Plans and Priorities.

Canada. Department of National Defence. Canada First Defence Strategy. Ottawa: 2008.

Canada. Department of National Defence. Canada's International Policy Statement: A Role of Pride and Influence in the World - Defence. Ottawa: 2005. 
Canada. Department of National Defence. Chief Review Services. Audit of Fixed Wing Search and Rescue (FWSAR) Project. Ottawa: 2009.

Canada. Department of National Defence. Chief Review Services. Audit of the Halifax-Class Modernization/Frigate Life Extension (HCM/FELEX) Project (Ottawa: 2011).

Canada. Department of National Defence. Chief Review Services. Internal Audit of Medium Support Vehicle System (MSVS) Project. Ottawa: 2014.

Canada. Department of National Defence. Chief Review Services. Perspectives on the Capital Equipment Acquisition Process - Final Report. Ottawa: 2006.

Canada. Department of National Defence. Chief Review Services: Internal Audit of the Joint Support Ship (JSS) Project. Ottawa: November 2011. Accessed online January 3, 2017: http://www.crs.forces.gc.ca/reports-rapports/2011/176P0934-eng.aspx.

Canada. Department of National Defence. Defence Performance Report 2008-2009.

Canada. Department of National Defence. Defence Policy Statement (Ottawa: 2005), 14.

Canada. Department of National Defence. DND News Release. "Major General Ian Poulter. U.S. Department of Defense. Defense Technical Information Centre, "Canadian Army Support Vehicles, February 6, 2012”. Accessed online June 26, 2017:

http://www.dtic.mil/ndia/2012/tactical/poulter.pdf - 2012-02-16.

Canada. Department of National Defence. DND Press Release. "Minister Nicholson announces names for the Royal Canadian Navy's new Joint Support Ships," October 25, 2013. Accessed online January 5, 2017: http://www.forces.gc.ca/en/news/article.page?doc=minister-nicholsonannounces-names-for-the-royal-canadian-navy-s-new-joint-support-ships/hn74yaf6.

Canada. Department of National Defence. Leadmark 2050: Canada in a New Maritime World. Ottawa: 2016.

Canada. Department of National Defence. Leadmark: The Navy's Strategy for 2020 (Ottawa: Directorate of Maritime Strategy, 2001).

Canada. Department of National Defence. Leadmark: The Navy's Strategy for 2020 (Ottawa: 2001), 68 .

Canada. Department of National Defence. Major Crown Projects: Joint Support Ship (JSS) 2008-2009. Ottawa: 2008. 
Canada. Department of National Defence. Major Crown Projects: Joint Support Ship (JSS) 2009-2010. Ottawa: 2009.

Canada. Department of National Defence. Major Crown Projects: Joint Support Ship (JSS) 2011-2012.

Canada. Department of National Defence. National Defence: 2008-2009 Report on Plans and Priorities (Ottawa: 2008), 33-34.

Canada. Department of National Defence. National Defence: 2010-2011 Report on Plans and Priorities (Ottawa: 2010), 28; Canada. Department of National Defence. National Defence: 20112012 Report on Plans and Priorities (Ottawa: 2011), 25.

Canada. Department of National Defence. National Defence: 2012-2013 Report on Plans and Priorities (Ottawa: 2012), 31.

Canada. Department of National Defence. Operational Research Division. Afloat Logistics and Sealift Capability: Simulation-based Fleet Sizing 1. Ottawa: 2001.

Canada. Department of National Defence. Patrol Craft Training vessels (Orca-class). Accessible online at: http://www.navy-marine.forces.gc.ca/en/fleet-units/minor-orca.page.

Canada. Department of National Defence. Report on Plans and Priorities 2006-2007.

Canada. Department of National Defence. Report on Plans and Priorities 2011-2012;

Canada. Department of National Defence. Report on Plans and Priorities 2012-2013;

Canada. Department of National Defence. Report on Plans and Priorities 2013-2014.

Canada. Department of National Defence. Report on Plans and Priorities 2014-2015.

Canada. Department of National Defence. Report to the Minister of National Defence by the Advisory Committee on Administrative Efficiency. Ottawa: 2003.

Canada. Department of National Defence. Strong, Secure, Engaged: Canada's Defence Policy (Ottawa: 2017).

Canada. House of Commons. Standing Committee on National Defence and Veterans Affairs, Procurement Study, 2nd Session, 36th Parliament, Report no. 3, June 24, 2000. 
Canada. House of Commons. Standing Committee on National Defence and Veterans Affairs, Procurement of Canada's Victoria Class Submarines, 1st Session, 38th Parliament, Report no. 1, April 2005.

Canada. House of Commons. Standing Committee on National Defence, Evidence, 1st session, 42nd Parliament, Meeting No. 28, November 17, 2016.

Canada. House of Commons. Standing Committee on National Defence. Canada and the Defence of North America, $2^{\text {nd }}$ Session, $41^{\text {st }}$ Parliament, Report no. 13, 2015.

Canada. House of Commons. Standing Committee on National Defence. Vice Admiral Mark Norman, November 18, 2014.

Canada. House of Commons. Standing Committee on National Defence. Evidence, 1st session, 42nd Parliament, Meeting No. 24, October 27, 2016.

Canada. Industry Canada. "Industrial and Technological Benefits Policy: Value Proposition Guide" (Ottawa: 2014).

Canada. Industry Canada. "Procurement projects - Marine projects." Accessed online July 10, 2017: https://www.ic.gc.ca/eic/site/042.nsf/eng/h_00017.html\#marine.

Canada. Industry Canada. A New Policy Framework For The Canadian Shipbuilding and Industrial Marine Industry (Ottawa: 2001).

Canada. Industry Canada. Medium Support Vehicle System Project - Specially Equipped Vehicles - Baseline Shelters. Accessed online June 25, 2017:

http://www.ic.gc.ca/eic/site/042.nsf/eng/aa00084.html.

Canada. Innovation, Science and Economic Development Canada. National Shipbuilding Strategy, November 3, 2016. Accessed online February 5, 2017:

https://www.ic.gc.ca/eic/site/sim-cnmi.nsf/eng/uv00050.html.

Canada. Library of Parliament - Parliamentary Information and Research Service. The Evolution of Defence Procurement in Canada. Ottawa: 2016.

Canada. Library of Parliament - Parliamentary Information and Research Service. The Evolution of Defence Procurement in Canada.

Canada. National Defence and the Canadian Armed Forces, Fixed-Wing Search and Rescue Replacement Project, April 13, 2017. Accessed online May 16, 2017: http://www.forces.gc.ca/en/business-equipment/fixed-wing-snr.page. 
Canada. National Defence and the Canadian Armed Forces. "Chief of Defence Staff and Army Commander issue a joint statement on the decision not to proceed with the procurement process for the Close Combat Vehicle." Statement. Accessed July 17, 2017:

http://www.forces.gc.ca/en/news/article.page?doc=chief-of-the-defence-staff-and-armycommander-issue-a-joint-statement-on-the-decision-not-to-proceed-with-the-procurementprocess-for-the-close-combat-vehicle/hpf8gsnx.

Canada. National Defence and the Canadian Armed Forces. "Halifax-class Modernization/ Frigate Life Extension (HCM/FELEX)". Accessed online July 4, 2017:

https://www.canada.ca/en/department-national-defence/news/2016/11/halifax-classmodernization-frigate-life-extension-felex.html.

Canada. National Defence and the Canadian Armed Forces. "Halifax-class Modernization/Frigate Life Extension (HCM/FELEX)".

Canada. National Defence and the Canadian Armed Forces. "Halifax-class modernization and frigate life extension." Accessed online July 7, 2017: http://www.forces.gc.ca/en/businessequipment/halifax-frigate.page.

Canada. National Defence and the Canadian Armed Forces. 2004-2005 Report on Plans and Priorities.

Canada. National Defence and the Canadian Armed Forces. 2006-2007 Report on Plans and Priorities.

Canada. National Defence and the Canadian Armed Forces. 2008-2009 Report on Plans and Priorities.

Canada. National Defence and the Canadian Armed Forces. 2012-2013 Status on Major Crown Projects.

Canada. National Defence and the Canadian Armed Forces. 2014-2015 Report on Plans and Priorities: Status Report on Transformational and Major Crown Projects.

Canada. National Defence and the Canadian Armed Forces. 2017-18 Departmental Plan. "Status report on transformational and major Crown projects." Accessed online July 14, 2017: http://www.forces.gc.ca/en/about-reports-pubs-report-plan-priorities/2017-status-report-ontransformational-and-major-crown-projects.page\#p8.

Canada. National Defence and the Canadian Armed Forces. 2017-18 Departmental Plan: Status Report on Transformational and Major Crown Projects. Accessed online July 7, 2017: 
http:/www.forces.gc.ca/en/about-reports-pubs-report-plan-priorities/2017-status-report-ontransformational-and-major-crown-projects.page\#p11.

Canada. National Defence and the Canadian Armed Forces. 2017-18 Departmental Plan: Status Report on Transformational and Major Crown Projects; Canada. National Defence and the Canadian Armed Forces. "Halifax-class modernization and frigate life extension." Accessed online July 8, 2017: http://www.forces.gc.ca/en/business-equipment/halifax-frigate.page.

Canada. National Defence and the Canadian Armed Forces. 2017-18 Departmental Plan: Status Report on Transformational and Major Crown Projects.

Canada. National Defence and the Canadian Armed Forces. Canada First Defence Strategy, 2008.

Canada. National Defence and the Canadian Armed Forces. Canadian Army Reserve. Accessed online June 27, 2017: http://www.army-armee.forces.gc.ca/en/reserve/index.page.

Canada. National Defence and the Canadian Armed Forces. CC-138 Twin Otter, October 12, 2016. Accessed online May 16, 2017: http://www.rcaf-arc.forces.gc.ca/en/aircraft-current/cc138.page.

Canada. National Defence and the Canadian Armed Forces. Chief Review Services. Evaluation of the DND/CAF Contribution to the National SAR Program (Ottawa: 2015).

Canada. National Defence and the Canadian Armed Forces. Chief Review Services: Audit of Fixed Wing Search and Rescue (FWSAR) Project, (Ottawa: 2009).

Canada. National Defence and the Canadian Armed Forces. Chief Review Services: Evaluation of the DND/CAF Contribution to the National SAR Program (Ottawa: 2015).

Canada. National Defence and the Canadian Armed Forces. Defence Acquisition Guide 2016 (Ottawa: 2016).

Canada. National Defence and the Canadian Armed Forces. Defence Policy Statement, 2005.

Canada. National Defence and the Canadian Armed Forces. Leadmark 2050: Canada in a New Maritime World (Ottawa: 2016), 43.

Canada. National Defence and the Canadian Armed Forces. Search and Rescue Posture Review 2013 (Ottawa: 2013). 
Canada. National Defence and the Canadian Armed Forces. Strong, Secure, Engaged: Canada's Defence Policy (Ottawa: 2017).

Canada. National Defence. "'Canada First" Defence Strategy Procurement." Ottawa: Department of National Defence, 2008.

Canada. National Research Council Canada. Review of the Statement of Operational Requirement for the Fixed Wing Search and Rescue Aircraft. Report No. CR-FRL-2010-0025 (Ottawa: 2010).

Canada. Office of the Auditor General of Canada. Chapter 2: Replacing Canada's Fighter Jets. Ottawa: Spring 2012.

Canada. Office of the Auditor General of Canada. Chapter 3: National Shipbuilding Procurement Strategy. Report of the Auditor General of Canada. Ottawa: Fall 2013.

Canada. Office of the Auditor General of Canada. Chapter 3: Upgrading the CF-18 Fighter Aircraft. Ottawa: 2004.

Canada. Office of the Auditor General of Canada. Chapter 4: National Defence: Equipping and Modernizing the Canadian Forces. Ottawa: 1998.

Canada. Office of the Auditor General of Canada. Chapter 5: Acquiring Military Vehicles for Use in Afghanistan. Ottawa: 2009.

Canada. Office of the Auditor General of Canada. Chapter 6 - Acquisition of Military Helicopters (Ottawa: 2010); Canada. National Defence and the Canadian Armed Forces. "CH148 Cyclone procurement project." Accessed online July 9, 2017:

http://www.forces.gc.ca/en/business-equipment/maritime-helicoper.page.

Canada. Office of the Auditor General of Canada. Chapter 6: Acquisition of Military Helicopters. Ottawa: 2010.

Canada. Office of the Auditor General of Canada. National Shipbuilding Procurement Strategy. Ottawa: Fall 2013.

Canada. Office of the Auditor General, Chapter 17: National Defence. Ottawa: 1992.

Canada. Office of the Auditor General, Chapter 4: National Defence: Equipping and Modernizing the Canadian Forces. Ottawa: 1998.

Canada. Office of the Auditor General, Chapter 9: National Defence. Ottawa: 1987. 
Canada. Office of the Parliamentary Budget Officer. An Estimate of the Fiscal Impact of Canada's Proposed Acquisition of the F-35 Lightning II Joint Strike Fighter. Ottawa: 2011.

Canada. Office of the Parliamentary Budget Officer. Feasibility of Budget for Acquisition of Two Joint Support Ships. Ottawa: 2013.

Canada. Office of the Parliamentary Budget Officer. Fiscal Sustainability of Canada's National Defence Program. Ottawa: 2015.

Canada. Parliament. House of Commons. Standing Committee on National Defence. Evidence. $2^{\text {nd }}$ Sess., 40 ${ }^{\text {th }}$ Parliament, Meeting No. 2, February 9, 2009.

Canada. Parliament. House of Commons. Standing Committee on National Defence, Evidence, $1^{\text {st }}$ Session, 39 ${ }^{\text {th }}$ Parliament, Meeting No. 34, February 8, 2007.

Canada. Parliament. Office of the Parliamentary Budget Officer. The Cost of Canada's Surface Combatants (Ottawa: 2017).

Canada. Parliament. Senate. Standing Committee on National Security and Defence. Answering The Call: The Future Role of Canada's Primary Reserve, $1^{\text {st }}$ Sess., $41^{\text {st }}$ Parliament, Report No. 4 , December 11, 2012.

Canada. Parliament. Senate. Standing Committee on National Security and Defence. Military Underfunded: The Walk Must Match the Talk. 1st Sess., 42nd Parliament, Report No. 10, April 2017.

Canada. Prime minister of Canada. "Cabinet committee mandates and membership." accessed July 12, 2017. http://pm.gc.ca/eng/cabinet-committee-mandate-and-membership.

Canada. Privy Council Office, Speech from the Throne to Open the First Session of the 38th Parliament of Canada (2004). Accessed online June 5, 2017: http://www.pcobcp.gc.ca/index.asp?lang $=$ eng \&page $=$ information $\&$ sub $=$ publications $\&$ doc $=$ aarchives $/ \mathrm{sft}-$ ddt/2004_2-eng.htm.

Canada. Public Services and Procurement Canada. "3.170. Shipbuilding, Repair, Refit and Modernization.” Supply Manual, October 31, 2012. Accessed online December 16, 2016 : https://buyandsell.gc.ca/policy-and-guidelines/supply-manual/section/3/170.

Canada. Public Services and Procurement Canada. "About the National Shipbuilding Strategy". Accessed July 17, 2017: http://www.tpsgc-pwgsc.gc.ca/app-acq/amd-dp/mer-sea/sncnnss/apropos-about-eng.html 
Canada. Public Services and Procurement Canada. "Bidders fail to meet budget requirements." PSPC News Release, August 22, 2008.

Canada. Public Services and Procurement Canada. "National Shipbuilding Strategy: Services and Information." Accessible online: http://www.tpsgc-pwgsc.gc.ca/app-acq/amd-dp/mer-sea/sncnnss/index-eng.html.

Canada. Public Services and Procurement Canada. Defence Procurement Strategy. Accessed online September 23, 2016: https://www.tpsgc-pwgsc.gc.ca/app-acq/amd-dp/samd-dps/indexeng.html.

Canada. Public Services and Procurement Canada. Fixed-Wing Search and Rescue Aircraft Replacement Project - Independent Review of Evaluation Plans, Methods and Tools (2013). Accessed online April 15, 2017: http://www.tpsgc-pwgsc.gc.ca/app-acq/amd-dp/air/arsvffwsar/index-eng.html.

Canada. Public Services and Procurement Canada. Government of Canada News Release. "Vancouver Shipyards to build Medium Endurance Multi-Tasked Vessels and Offshore Patrol Vessels for the Canadian Coast Guard," October 7, 2013. Accessible online: http://news.gc.ca/web/article-en.do?nid=778419.

Canada. Public Services and Procurement Canada. Land: Medium support vehicle system. Accessed online June 29, 2017: https://www.tpsgc-pwgsc.gc.ca/app-acq/amd-dp/terreland/index-eng.html.

Canada. Public Services and Procurement Canada. National Shipbuilding Strategy: February 2012-December 2015 Status Report. Ottawa: December 2015.

Canada. Public Services and Procurement Canada. Shipbuilding projects to equip the Royal Canadian Navy and the Canadian Coast Guard-National Shipbuilding Strategy:

February 2012 to December 2015 status report. Accessible online: http://www.tpsgcpwgsc.gc.ca/app-acq/amd-dp/mer-sea/sncn-nss/rapport-report-20151231-3-eng.html\#a4.

Canada. Public Works and Government Services Canada. "Supply Manual." Accessed online August 8, 2016: https://buyandsell.gc.ca/policy-and-guidelines/supply-manual/section/1.

Canada. Standing Committee on National Defence. Procurement and Associated Processes, $39^{\text {th }}$ Parliament, $2^{\text {nd }}$ Session, 2008.

Canada. Treasury Board of Canada Secretariat, "About the Treasury Board of Canada." Accessed online July 13, 2017: https://www.canada.ca/en/treasury-boardsecretariat/corporate/about-treasury-board.html. 
Canada. Treasury Board of Canada Secretariat. "Treasury Board of Canada Secretariat." Accessed online August 9, 2016: https://www.canada.ca/en/treasury-board-secretariat.html.

Canada. Treasury Board of Canada Secretariat. ARCHIVED National Defence - 2009-10 Departmental Performance Report. Accessed online July 14, 2017: http://www.tbs-sct.gc.ca/dprrmr/2009-2010/inst/dnd/st-ts03-eng.asp\#fwsar-amf.

Canada. Treasury Board of Canada Secretariat. ARCHIVED National Defence - 2011-12 RPP Status Report on Transformational and Major Crown Projects. Accessed online July 15, 2017: https://www.tbs-sct.gc.ca/rpp/2011-2012/info/mcp-gpe-eng.asp\#jss-nsi.

Canada. Treasury Board of Canada Secretariat. National Defence: 2007-2008 Status Report on Major Crown Projects (Ottawa: 2008).

Canada. Treasury Board of Canada Secretariat. National Defence: Departmental Performance Reports 2006-07: Status Report on Major Crown Projects (Ottawa: 2007).

Canada. Treasury Board of Canada Secretariat. National Defence: Departmental Performance Reports 2007-08.

Canada. Treasury Board of Canada Secretariat. Status Report on Major Crown Projects for fiscal year 2006-2007 (Ottawa: 2007).

Canadian Press, "Flying Buffalos not extinct - yet.” The Halifax Daily News, October 22, 2007.

Canadian Press. "After years of missteps, Canadian military officials hope procurement now on track," CBC News. Accessed online July 9, 2017: http://www.cbc.ca/news/politics/militaryprocurement-national-defence-canada-spending-1.4197017.

Canadian Press. "Military truck purchase cancelled due to cost concerns," $C B C$ News, http://www.cbc.ca/news/canada/military-truck-purchase-cancelled-due-to-cost-concerns1.1273570 .

Canadian Press. "Ottawa's backroom bid for French helicopter ships sidelined by election." CBC News, September 20, 2015. Accessible online: http://www.cbc.ca/news/politics/canada-election2015-backroom-bid-french-ships-election-1.3235816

Canadian Press. "Private planes could aid search and rescue work." The Hamilton Spectator, February 15, 2011.

Canadian Press. "Proposals drawn up to replace aging search/rescue fleet." Prince George Citizen, July 27, 2007. 
Canadian Press. "Replacement for 50-year-old air force search planes postponed." Prince George Citizen, March 9, 2012.

Canadian Press. "Snooze, lose: Defence department gave up $\$ 300 \mathrm{M}$ due to foot dragging." Prince George Citizen, May 13, 2009.

Carson, Bruce. 14 Days: Making the Conservative Movement in Canada. Montreal-Kingston: McGill-Queen's University Press, 2014.

CBC News. "Irving family closing idled Saint John shipyard." CBC News (Online), June 27, 2003. Accessible online: http://www.cbc.ca/news/business/irving-family-closing-idled-saintjohn-shipyard-1.396417

CBC News. "Quebec's Davie Shipyard launches new ship Cecon Pride." CBC News (Online), October 25, 2013. Accessible online: http://www.cbc.ca/news/business/quebec-s-davie-shipyardlaunches-new-ship-cecon-pride-1.2251681.

Chase, Steven. "B.C. firm chasing \$3-billion deal to modernize rescue plane." Globe and Mail, January 6, 2009, A4.

Chase, Steven. "Military left waiting on big-ticket items as Liberals shrink funding in budget." Globe and Mail, March 22, 2016.

Chase, Steven. "Tory defence strategy runs into trouble." Globe and Mail, June 3, 2008 , A4.

Cheeseman, Graeme. "Canada's Post-Cold War Military Blues and the Lessons for Australia." Pacifica Review 13, no. 2 (2001).

Chrétien, Jean. My Years As Prime minister. Toronto: Vintage Canada, 2008.

Chuter, Andrew. “Audit Cites UK's Strides on Procurement Fixes”, DefenseNews. Com (16 January 2015): http://www.defensenews.com/story/defense/policybudget/budget/2015/01/13/national-audit-office-uk-procurement/21693759/.

Chuter, Andrew. "British Navy Sees Delay In Delivery Of South Korean-Built Tanker." Defense News, August 1, 2016. Accessible online:

http://www.defensenews.com/story/defense/naval/2016/08/01/british-navy-sees-delay-deliverysouth-korean-built-tanker/87918638/.

Collier, David. “Understanding Process Tracing," PS: Political Science and Politics 44, No. 4 (2011). 
Collins, Jeffrey F. "No such thing as a bargain in defence procurement." National Post, July 2, 2015.

Collins, Jeffrey. "The Perpetual Search for Efficiency: The Canadian Approach to the RMA and Military Transformation", in Reassessing The Revolution In Military Affairs: Transformation, Evolution and Lessons Learnt, eds. Jeffrey Collins and Andrew Futter (London: Palgrave Macmillan, 2015).

Conley, Kathleen. "Campaigning for Change: Organizational Processes, Governmental Politics and the Revolution in Military Affairs," Airpower Journal (Fall, 1998).

Connolly, Amanda. "Re-evaluate Oshkosh Defense's bid for \$834M-deal: trade tribunal to Public Works", iPolitics, accessed August 8, 2016, https://ipolitics.ca/2016/05/24/re-evaluateoshkosh-defenses-bid-for-834m-deal-trade-tribunal-to-public-works/.

Connolly, Amanda. "Trade tribunal dismisses challenge of search-and-rescue procurement," iPolitics, accessed July 13, 2017, http://ipolitics.ca/2017/05/05/trade-tribunal-dismisseschallenge-of-search-and-rescue-procurement/.

Connolly, Amanda. "Trade tribunal investigating support contract for fixed-wing search and rescue." iPolitics. Accessed online March 27, 2017: http://ipolitics.ca/2017/03/27/trade-tribunalinvestigating-support-contract-for-fixed-wing-sr/.

Connors, Shaun. "First batch of Overlander trucks delivered to ADF", IHS Jane's Defence Weekly, 14 April 2016. Accessed online February 21, 2017:

http://www.janes.com/article/59476/first-batch-of-overlander-trucks-delivered-to-adf.

Conservative Party of Canada. Stand Up For Canada (Ottawa: 2006).

Cooper, Barry. "Getting there from here." National Post, August 8, 2005.

Cox, Kevin. "Canada's largest shipyard closes." The Globe and Mail, June 27, 2003. Accessible online: http://www.theglobeandmail.com/news/national/canadas-largest-shipyardcloses/article22617919/.

CTV News. "Navy considers modified designs for new supply ship." Accessed online May 11, 2017: http://www.ctvnews.ca/navy-considers-modified-designs-for-new-supply-ship-1.617026.

Cudmore, James. "Davie Shipyard's $\$ 700 \mathrm{M}$ deal for navy supply ship retrofit to go ahead." CBC News. Accessed online July 17, 2017: http://www.cbc.ca/news/politics/davie-shipyard-s-700mdeal-for-navy-supply-ship-retrofit-to-go-ahead-1.3344037. 
Cudmore, James. "Military truck purchase cancelled due to cost concerns", CBC News, July 11, 2012.

Davies, Andrew. "Keep on Truckin", ASPI: The Strategist (30 June 2015). accessed February 20, 2017: https://www.aspistrategist.org.au/keep-on-truckin/.

Davies, Charles. “Understanding Defence Procurement," Canadian Military Journal 15, no. 2 (2015).

Dawson, Anne. "Ottawa ready to open purse to buy new ships, helicopters: Total military spending package worth up to \$8B.” Edmonton Journal, April 13, 2004.

Dempster, Doug. "Navigating Complexity: A tale of three projects." Vanguard, August/September 2015, 32.

Den Tandt, Michael. "\$3.8B plan to buy search-and-rescue planes to go ahead." Ottawa Citizen, May 29, 2012, A4.

Den Tandt, Michael. "Military's fast-track buying plan put on hold." Globe and Mail, November $16,2005$.

Den Tandt, Michael. "Ottawa considers aircraft purchase; \$12-billion military contract could bypass bid process." Globe and Mail, November 11, 2005.

Desrosiers, Marie-Eve and Philippe Lagassé, "Canada and the Bureaucratic Politics of State Fragility," Diplomacy \& Statecraft 20 (2009).

DID Staff, "Overlander is On! Australia's A \$ 3 Bn Vehicle Program", Defense Industry Daily, 6 October 2015. Accessed online February 21, 2017:

https://www.defenseindustrydaily.com/overlander-is-on-australia-issues-a-3bn-rft-01628/

Dobson, Carl. "New frigate systems deliver new capability." Vanguard (Feb/Mar 2013. Accessed online September 9, 2016: http://www.vanguardcanada.com/2013/03/20/new-frigatesystems-deliver-new-capability/

Dowdy, William L. "The Canadian Navy: Torpedoed Again”, Armed Forces \& Society 16, no. 1 (1989).

Edgar, Alistair David and David Haglund. The Canadian Defence Industry in the New Global Environment (Montreal-Kingston: McGill-Queen's University Press, 1995). 
Farrell, Theo. "Waste in Weapons Acquisition: How the Americans Do It All Wrong." Contemporary Security Policy 16, No. 2 (1995).

Fergusson, James. "In Search of a Strategy." In The Economics of Offsets, edited by Stephen Martin. Amsterdam: Harwood Academic, 1996.

Finn, Patrick Rear Admiral (ret'd.), Assistant Deputy Minister (Material), Testimony before the Standing House Committee on National Defence, May 5, 2016.

Fisher, Matthew. "'Tired' navy limps home from gruelling Gulf mission,” Ottawa Citizen, September 21, 2003 ,. A3.

Fitzsimmons, Daniel. "Transformation in the Canadian Forces: A Sociological Institutionalist Approach to Change in the CF from Peacekeeper to War Fighter." Innovations: A Journal of Politics 8 (2009).

Fonberg, Robert then-Deputy Minister of National Defence, testimony before the Standing Senate Committee on National Security and Defence, May 25, 2009.

Fox, William B. "The Politics of Procurement: The Low Level Air Defence Decision of 1986," in Canada's Defence Industrial Base: The Political Economy of Preparedness and Procurement, ed. David G. Haglund (Kingston: Ronald P. Frye and Company, 1988).

Frenette, Yves, “Conscripting Canada's Past: The Harper Government and the Politics of Memory”, Canadian Journal of History 49, no. 1 (2014), 49-65;

Gammer, Nicholas. "The Afghanistan Task Force and Prime ministerial Leadership: Tactical Retreat or a New Direction in Managing Canadian Foreign Policy?" American Review of Canadian Studies 43, No. 4 (2013).

Geddes, John. "How Stephen Harper is rewriting history.” Maclean's, July 29, 2013. Accessed August 31, 2017: http:/www.macleans.ca/news/canada/written-by-the-victors/.

Gerring, John. "What is a Case Study and What Is It Good for?" American Political Science Review 98, No. 2 (2004).

Gillies, Rob. "Canada to buy used Australian jets over new Boeing aircraft." Financial Post. Accessed online January 8, 2018: http://business.financialpost.com/pmn/business-pmn/canadato-buy-used-australian-fighter-jets

Government of Canada. A New Policy Framework For The Canadian Shipbuilding and Industrial Marine Industry (Ottawa: Industry Canada, 2001). 
Granatstein, Jack L. Canada's Army: Waging War and Keeping the Peace. Toronto: University of Toronto Press, 2011.

Greener, Peter. Timing is Everything: The Politics of New Zealand Defence Acquisition Decision Making. Canberra: Australia National University Press, 2009.

Greenwalt, William C. Five Factors Plaguing Pentagon Procurement (Washington, D.C.: American Enterprise Institute for Public Policy Research, 2013).

Gunn, Andrea. "Halifax-class frigate refits over half done." Chronicle-Herald, December 25, 2015;

Gunn, Andrea. "Halifax-class frigate refits over half done." Chronicle-Herald, December 25, 2015.

Hemmerdinger, Jon. "US Coast Guard to acquire USAF's remaining C-27J Spartans." FlightGlobal.Com, January 6, 2014. Accessed online June 11, 2017:

https://www.flightglobal.com/news/articles/us-coast-guard-to-acquire-usafs-remaining-c-27jspartans-394575/.

Hillier, General Rick. A Soldier First: Bullets, Bureaucrats and the Politics of War. Toronto: Harper Collins Publishers Ltd., 2009.

Hobson, Sharon. "Plain Talk: JSS Adrift in a Strategic Black Hole." Canadian Naval Review 6, no. 3 (2010).

Huebert, Rob. Canada and the Changing International Arctic: At the Crossroads of Cooperation and Conflict (Montreal: Institute for Research on Public Policy, 2008).

Huebert, Rob. The Royal Canadian Navy: Facing Rough Seas (Calgary: Canadian Global Affairs Institute, 2016).

Huebert, Rob. The Royal Canadian Navy: Facing Rough Seas (Calgary: Canadian Global Affairs Institute, 2016), 1, 7-8.

Ivison, John. "From helicopters to fighter jets, problems facing Canada's defence procurement are systemic.” National Post, May 28, 2015.

Jacobsen, Henning. “The RCN's Joint Support Ship disaster.” Vanguard, August 12, 2015. Accessed online May 17, 2016: http://www.vanguardcanada.com/2015/08/12/the-joint-supportship-debacle/. 
Jockel, Joseph T. and Joel J. Sokolsky. "Canada and NATO: Keeping Ottawa in, expenses down, criticism out... and the country secure”, International Journal (Spring 2009).

Johnson, David. Thinking Government: Public Administration and Politics in Canada (Toronto: University of Toronto, 2011).

Jones, Peter and Philippe Lagassé, "Rhetoric versus reality: Canadian defence planning in a time of austerity," Defense \& Security Analysis 28, no. 2 (2012).

Kerr, Julian. "First-of-class Hobart launched as government discloses further delays, costs", in Jane's Defence Weekly, 25 May 2015. http://www.janes.com/article/51644/first-of-class-hobartlaunched-as-government-discloses-further-delays-costs.

Krasner, Stephen D. “Are Bureaucracies Important? (Or Allison Wonderland), Foreign Policy (Summer 1972).

Lagassé, Philippe and Paul Robinson. Reviving Realism in the Canadian Defence Debate (Kingston, ON: Centre for International Relations, Queen's University, 2008).

Lagassé, Philippe. Recapitalizing the Canadian Forces' Major Fleets (Calgary: CIC and CDFAI, 2012).

LeBlanc, Daniel. “Air force may abandon \$3-billion plan.” Globe and Mail, February 6, 2007.

Lerhe, Eric. "Sailing into the future." Policy Options, December 9, 2015;

Leslie, Andrew Lieutenant General, Chief of Land Staff and Commander of the Army, testimony before the Standing House Committee on National Defence, February 22, 2007.

Leuprecht, Christian and Joel J. Sokolsky. "Defense Policy 'Walmart Style': Canadian Lessons in 'not-so-grand' Grand Strategy." Armed Forces \& Society 41, No. 3 (2015).

Levy, Jack S. “Case Studies: Types, Designs, and Logics of Inference," Conflict Management and Peace Science 25 (2008).

Liberal Party of Canada. Securing Canada's Success (Ottawa: 2006), 73.

Lucas, J.S. Lieutenant General, then-Chief of the Air Staff, Testimony before the Standing House Committee on National Defence, February 15, 2007.

Mack Defense. "Mack Defense Awarded \$725 million CAD Contract to Supply More than 1,500 Trucks to the Canadian Armed Forces.” Accessed online June 25, 2017 : http://www.mackdefense.com/. 
MacKay, Peter. "Ships' refit good news.” The Halifax Daily News, July 11, 2007, 13.

Maddison, Paul Vice-Admiral, then Chief of Maritime Staff and Commander of the Navy, testimony before the Standing House Committee on National Defence, December 6, 2011.

Maloney, Sean M. Force Structure or Forced Structure? The 1994 White Paper on Defence and the Canadian Forces in the 1990s (Montreal: Institute for Research on Public Policy, 2004).

Marsh, Kevin. "Obama's Surge: A Bureaucratic Politics Analysis of the Decision to Order a Troop Surge in the Afghanistan War," Foreign Policy Analysis 10, no. 3 (2014).

McDonough, David and Brian Lee Crowley. Interim Super Hornet Survey Project (Ottawa: Macdonald-Laurier Institute, 2017).

McDonough, David. "Mind the 'gaps' in Canadian defence policy, even after Budget 2015," OpenCanada.Org. Accessed online July 16, 2017: https://www.opencanada.org/features/mindthe-gaps-in-canadian-defence-policy-even-after-budget-2015/.

McDougall, Stephen. "Army shrinks, downgrades truck fleet." Sherbrooke Record, January 12, 2009.

McKnight, Zoe. "Navy adopts German design for ships to be built in North Vancouver." Vancouver Sun, June 3, 2013. Accessible online:

http://www.vancouversun.com/Navy+adopts+German+design+ships+built+North+Vancouver/8 $\underline{468320 / \text { story.html. }}$

Michaud, Nelson. "Bureaucratic Politics and the Shaping of Policies: Can We Measure Pulling and Hauling Games?" Canadian Journal of Political Science 35.2 (2002).

Middlemiss, D.W. and J. Sokolsky. Canadian Defence: Decisions and Determinants. Toronto: Harcourt Brace Jovanovich Canada Inc., 1989.

Middlemiss, Dan. "Defence Procurement in Canada," in Canada's International Security Policy, eds. David B. Dewitt and David Leyton-Brown (Scarborough, ON: Prentice-Hall Canada Inc., 1995).

Milewski, Terry. "Harper government gave Seaspan shipyard \$40M contract on election day." CBC News (Online), May 6, 2016. Accessible online: http://www.cbc.ca/news/politics/harpershipbuilding-contract-election-1.3568283.

Military Today. "MLVW: Light utility truck." Accessed online April 3, 2017:

http://www.military-today.com/trucks/mlvw.htm. 
Milner, Marc. Canada's Navy: The First Century. Toronto: University of Toronto Press, 2010.

Moens, Alexander. Canada's Defence Policy Renewal: Broad Capabilities in an Allied and Partners Framework. (Ottawa: Conference of Defence Associations Institute, 2016).

Morton, Desmond. A Military History of Canada. Toronto: McClelland \& Stewart Ltd., 2007.

Murray, Robert W. and John McCoy, "From Middle Power to Peacebuilder: The Use of the Canadian Forces in Modern Canadian Foreign Policy," American Review of Canadian Studies 40, No. 2 (2010).

New Zealand. Ministry of Defence. "ANZAC ships upgrade frigate systems upgrade (FSU)". Accessed online July 8, 2017: http://www.defence.govt.nz/what-we-do/delivering-defencecapability/defence-capability-projects/anzac-ships-upgrade-frigate-systems-upgrade-fsu/;

Nossal, Kim Richard, "Defending the 'realm': Canadian strategic culture revisited." International Journal 59, no. 3 (Summer, 2004).

Nossal, Kim Richard. "Allison through the (Ottawa) Looking Glass: bureaucratic politics and foreign policy in a parliamentary system," Canadian Public Administration 22, no. 4 (1979).

Nossal, Kim Richard. "Defense Policy and the Atmospherics of Canada-U.S. Relations: The Case of the Harper Conservatives." American Review of Canadian Studies 37, No. 1 (2007).

Nossal, Kim Richard. "Late Learners: Canada, the F-35, and lessons from the New Fighter Aircraft program," International Journal 68, no. 1 (2012-13).

Nossal, Kim Richard. "Rationality and non-rationality in Canadian defence policy," in Canada's International Security Policy, eds. David B. Dewitt and David Leyton-Brown (Scarborough: Prentice-Hall Canada, 1995).

Nossal, Kim Richard. Charlie Foxtrot: Fixing Defence Procurement in Canada (Toronto: Dundurn Press, 2016).

Ørvik, Nils. "Canadian security and 'defence against help'.” Survival 26, No.1 (1984).

Perry, Dave. "A Primer on Recent Canadian Defence Budgeting Trends and Implications," School of Public Policy Research Papers 8, No. 15 (2015).

Perry, Dave. Putting The 'Armed' Back Into The Canadian Armed Forces: Improving Defence Procurement in Canada (Ottawa: Macdonald-Laurier Institute, 2015).

Perry, David. "Canada's Seven Billion Dollar War," International Journal 63, no. 3 (2008). 
Perry, David. "The Privatization of the Canadian Military," International Journal 64, no. 3 (2009).

Perry, David. "A Return to Realism: Canadian Defence Policy after the Great Recession," Defence Studies 13, No. 3 (2013).

Perry, David. 2015 Status Report on Major Defence Equipment Procurements (Calgary: Canadian Global Affairs Institute, 2015).

Perry, David. Leading From Behind is Still Leading: Canada and the International Intervention in Libya. Ottawa: Conference of Defence Associations Institute, 2012.

Petrolekas, George and David Perry. "Buy this ship.” National Post, September 26, 2013.

Pickford, Andrew and Collins, Jeffrey F. Canada can only learn so much from Australian defence policy (Ottawa: Macdonald-Laurier Institute, March 3, 2016). Accessible online: http://www.macdonaldlaurier.ca/canada-can-only-learn-so-much-from-australian-defencepolicy-andrew-pickford-and-jeffrey-collins-for-inside-policy/.

Plamondon, Aaron. "Equipment Procurement in Canada and the Civil-Military Relationship: Past and Present." Occasional Paper, No. 2. Calgary: Centre for Military and Strategic Studies, 2008.

Plamondon, Aaron. The Politics of Procurement. Vancouver: UBC Press, 2010.

Postmedia News. "RCAF's new search and rescue plan: refurbish the U.S. president's old helicopters." National Post, June 4, 2015.

Postmedia News. "Top DND procurement goal is for search-and-rescue." Nanaimo Daily News, May 30, 2011, A9.

Pugliese, David. "\$3B Buffalo retirement project back on government radar." Edmonton Journal, January 27, 2010.

Pugliese, David. "Afghan war leaves Forces unable to buy new search planes." Ottawa Citizen, April 26, 2007, A1.

Pugliese, David. “Anger erupts over army truck purchase”, The Leader-Post, January 26, 2009.

Pugliese, David. "Canada still can't land search and rescue planes." Alberni Valley Times, April 6, 2010, A7. 
Pugliese, David. "Canada's frigates need \$2B upgrade: Crews forces to shuttle equipment from one warship to another." Ottawa Citizen, April 17, 2004, A1.

Pugliese, David. "Canada's frigates need \$2B upgrade: Crews forces to shuttle equipment from one warship to another." Ottawa Citizen, April 17, 2004, A1.

Pugliese, David. "Canadian Forces to stockpile military equipment in Arctic 'hubs' for faster response in case of emergency." National Post, August 21, 2014.

Pugliese, David. "Canadian navy opts for non-American upgrade; Frigates to be modernized with other technology to avoid delays." Edmonton Journal, January 25, 2010, A4.

Pugliese, David. “Cash-strapped navy could take out ships.” Times Colonist, May 13, 2010, A1.

Pugliese, David. "Defence plan outlines long-range strategy.” The Gazette, December 4, 2006.

Pugliese, David. "Delayed trucks now due in 2017.” Ottawa Citizen, May 4, 2015.

Pugliese, David. "DND says delay on delivery of first Joint Support Ship is several months." Ottawa Citizen, January 4, 2017.

Pugliese, David. "DND should rewrite requirements for \$3B search aircraft project: NRC." Ottawa Citizen March 17, 2010, A1.

Pugliese, David. "DND should rewrite requirements for \$3B search aircraft project: NRC." Ottawa Citizen March 17, 2010, A1.

Pugliese, David. "DND under fire for scoping out Dutch shipyard." Ottawa Citizen. August 6, 2008.

Pugliese, David. "DND urged to buy rescue aircraft." The Ottawa Citizen, April 6, 2010, A1;

Senior Government Official, Interview with the Author, September 23, 2016.

Pugliese, David. "DND wants new Italian SAR planes." The Ottawa Citizen, December 18, 2008, A6.

Pugliese, David. "Frigate deal part of campaign barrage; Tories to announce \$1.1-billion upgrade by lone bidder Lockheed Martin Canada." Times Colonist, September 8, 2008, A5. 
Pugliese, David. "Government Compensated ThyssenKrupp Marine Systems For Failed Joint Support Ship Project.” The Ottawa Citizen, January 21, 2014.

Pugliese, David. "Half of Navy vessels under repair, refit: Fixes, modernization lead to most challenging' year for officials.” Ottawa Citizen, April 21, 2014, A1.

Pugliese, David. "Industry Canada, DND feud over how to spend $\$ 3$ billion; Canadian jobs at centre of spat." The Ottawa Citizen, March 26, 2009, A1.

Pugliese, David. "Military reconsidering big-ticket spending priorities: Giant long-range transport planes may be back on table." The Ottawa Citizen, April 15, 2006.

Pugliese, David. "Military slips up on shipbuilding history.” Ottawa Citizen, January 5, 2016.

Pugliese, David. "Missile upgrade will beef up frigates' defence." The Ottawa Citizen, December 2, 2000, A6.

Pugliese, David. "Modernization of Halifax-class frigates a success, says government." Ottawa Citizen, November 24, 2014).

Pugliese, David. "More than half Canada's Navy vessels are either repaired, modernized or otherwise at reduced readiness.” National Post, April 20, 2014.

Pugliese, David. "Navy looks into buying fuel tankers.” The Telegram, August 28, 2008.

Pugliese, David. "Nearly half of military contracts had no competition, report finds." The Ottawa Citizen, June 11, 2007.

Pugliese, David. “Ottawa cancels 'priority' navy contracts.” The Ottawa Citizen, August 23, 2008.

Pugliese, David. "RCAF fixed-wing SAR contract awarded to Airbus now being challenged in federal court." The Ottawa Citizen, February 23, 2017.

Pugliese, David. "Royal Canadian Navy picks a name for a third Joint Support Ship." The Ottawa Citizen, April 8, 2016. Accessed online January 5, 2017:

http://ottawacitizen.com/news/national/defence-watch/royal-canadian-navy-picks-a-name-for-athird-joint-support-ship.

Pugliese, David. "Shop at home policy adds $\$ 300$ million to Forces' truck costs." The Ottawa Citizen, February 2, 2004. 
Pugliese, David. "Start Over on Canadian Forces Fixed Wing Search and Rescue, Report Suggests." The Ottawa Citizen, February 12, 2010.

Pugliese, David. "Three frigates outfitted to take Cyclone helicopters." Ottawa Citizen, September 6, 2016.

Pugliese, David. “Tories eye privatizing search and rescue.” Ottawa Citizen, July 21, 2011.

Pugliese, David. "Tories freeze all spending on new gear for military." The Ottawa Citizen, April 15, 2006, A1.

Pugliese, David. "Two solitudes: The defence community is deeply divided over how our cashstrapped military should face the future. Scrap the navy or air force, and beef up the army?" The Ottawa Citizen, October 16, 2004.

Rhodes, Edward. "Do Bureaucratic Politics Matter? Some Disconfirming Findings from the Case of the U.S. Navy," World Politics 47, no. 1 (1994).

Richter, Andrew. "A Defense Renaissance? The Canadian Conservative Government and the Military," American Review of Canadian Studies 43, No. 3 (2013).

Richter, Andrew. "Forty Years of Neglect, Indifference, and Apathy: The Relentless Decline of Canada's Armed Forces", in Handbook of Canadian Foreign Policy, eds. Patrick James, Nelson Michaud, and Marc J. O’Reilly (Oxford: Lexington Books, 2006).

Richter, Andrew. "Strategic Ambitions and Fiscal Realities: Give the Navy Priority." Policy Options (April, 2002).

Ring, Tom. "The National Shipbuilding Procurement Strategy: How did we get to where we are now?” Policy Update (Calgary: Canadian Global Affairs Institute, 2016).

Robertson, Drew Vice-Admiral, then-Chief of Maritime Staff and Command of the Navy, testimony before the Standing House Committee on National Defence, February 22, 2007.

Ross, Dan, then-Assistant Deputy Minister (Materiel), testimony before the Standing Committee on National Defence, February 8, 2007.

Ross, Dan, then-Assistant Deputy Minister (Materiel), testimony before the Standing Senate Committee on National Security and Defence, May 25, 2009. 
Royal Netherlands Navy. "Ships." Accessed online December 16, 2016 :

https://www.defensie.nl/english/organisation/navy/contents/navy-units/ships.

Royal New Zealand Navy. "Meet the Feet" (2016). Accessed online December 16, 2016 :

http://navy.mil.nz/mtf/default.htm.

Savoie, Donald J. "Summerside: Revisiting the Base Closure." Canadian Journal of Regional Science 18, no. 1 (1995).

Savoie, Donald J. Governing from the Centre: The Concentration of Power in Canadian Politics. Toronto: University of Toronto Press, 1999.

Savoie, Donald J. Power: Where Is It? Montreal-Kingston: McGill-Queen's University Press, 2010.

Seaspan Shipyards, Value Proposition (2017). Accessed February 5, 2017:

http://www.seaspan.com/value-proposition-vp.

Seaspan Shipyards. Seaspan Shipyards - ORCAs. Accessible online at:

https://www.seaspan.com/seaspan-shipyards-orcas.

Seaspan Shipyards. Seaspan Shipyards New Builds. Accessible online at:

https://www.seaspan.com/seaspan-shipyards-new-builds

Shadwick, Martin. "Defence and the Conservatives", Canadian Military Journal 7, no. 1 (2006).

Shadwick, Martin. "Defence and the International Policy Statement," Canadian Military Journal 6, No. 2 (2005).

Shadwick, Martin. “The Joint Support Ship Revisited." Canadian Military Journal 11, no. 1 (2010).

Shadwick, Martin. “Volte-Face or False Hope?” Canadian Military Journal (Spring, 2005).

Shimooka, Richard. The Fourth Dimension: The F-35 Program, Defence Procurement, and the Conservative Government, 2006-2015 (Ottawa: Conference of Defence Associations Institute, 2016).

Sloan, Elinor. The Revolution in Military Affairs: Implications for Canada and NATO. Montreal and Kingston: McGill-Queen's University Press, 2002. 
Sloan, Elinor. Security and Defence in the Terrorist Era. Montreal: McGill-Queen's University Press, 2005.

Sloan, Elinor. "Stretched to the breaking point." National Post, June 17, 2008.

Sloan, Elinor. Canadian Defence Commitments: Overview and Status of Selected Acquisitions and Initiatives. Calgary: Canadian Defence and Foreign Affairs Institute, 2013.

Sloan, Elinor. Something Has to Give: Why Delays are the New Reality of Canada's Defence Procurement Strategy. Calgary: Canadian Defence \& Foreign Affairs Institute, 2014.

Smith, Marie-Danielle. "Harper government funded B.C. shipyard after Coast Guard ship contract despite saying it wouldn't." National Post, May 5, 2016. Accessed online May 15, 2017: http://news.nationalpost.com/news/canada/canadian-politics/harper-government-funded-bc-shipyard-after-coast-guard-ship-contract-despite-saying-it-wouldnt.

Smith, Marie-Danielle. "When cabinet decides: Parsing Canadian defence politics." Embassy News, March 9, 2016.

Smith, Martin A. "US bureaucratic politics and the decision to invade Iraq," Contemporary Politics 14, no. 1 (2008).

Sokolsky, Joel J. "A Seat at the Table: Canada and its Alliances." Armed Forces \& Society 16, No. 1 (1989).

Sokolsky, Joel J. 1995. Canada, Getting it Right this Time: The 1994 Defence White Paper. Strategic Studies Institute, Carlisle Barracks (Penn.), U.S. Army War College Sixth Annual Strategy Conference, April 26-28, 1995.

Solomon, Binyam and Craig Stone. "Accrual Budgeting and Defence Funding: Theory and Simulations." Defence and Peace Economics 24, No. 3 (2013).

Stein, Janice Gross and Eugene Lang. The Unexpected War: Canada in Kandahar. Toronto: Penguin Canada, 2007.

Stein, Janice Gross. "Ideas, even good ideas, are not enough: changing Canada's foreign and defence policies." International Journal 50 (Winter 1994-1995).

Stone, Craig. "Canadian Defence Policy and Spending." Defence and Peace Economics 16, no. 3 (2005). 
Stone, Craig. "Canada needs a defence industrial policy." International Journal 63, no. 2 (2008): 342.

Stone, Craig. "Defence Procurement and Industry," in Canada's National Security in the Post9/11 World, ed. David S. McDonough (Toronto: University of Toronto Press, 2012).

Stone, Craig. A Separate Defence Procurement Agency: Will It Actually Make A Difference? (Calgary: Canadian International Council and Canadian Defense and Foreign Affairs Institute, 2012).

Story, Donald C. and Russell Isinger, "The Origins of the Cancellation of the Canada's Avro CF105 Arrow Fighter Program: A Failure of Strategy," The Journal of Strategic Studies 30, no. 6 (2007).

Stouffer, Major Ray. "Cold War Air Power Choices for the RCAF: Paul Hellyer and the Selection of the CF-5 Freedom Fighter." Canadian Military Journal (Autumn 2006).

Sutherland, R.J. “Canada's Long Term Strategic Situation”, International Journal 17, no. 3 (1962).

Swick, Brenda C. "Review of Significant Canadian Federal Government Contracting Cases in 2016.” The National Law Review, January 12, 2017.

Taber, Jane. "Harper spins a new brand of patriotism." The Globe and Mail, August 19, 2011. Accessed July 11, 2017: https://beta.theglobeandmail.com/news/politics/ottawanotebook/harper-spins-a-new-brand-ofpatriotism/article618385/?ref=http://www.theglobeandmail.com\&;

The Canadian Encyclopedia. "Bombardier Inc.” Accessed online June 8, 2017: http://www.thecanadianencyclopedia.ca/en/article/bombardier-inc/.

Thomas, Doug. "Warship Developments: Life Extension Refits." Canadian Naval Review 8, no. 2 (2012): 41-42.

Thomas, Doug. "Afloat Logistics Support of Joint Support Ship?" Canadian Naval Review 9, no. 2 (2013).

Tracy, Nicholas. Two-Edged Sword: The Navy as an Instrument of Canadian Foreign Policy (Montreal-Kingston: McGill-Queen's University Press, 2014).

Tucker, Michael. Canadian Foreign Policy: Contemporary Issues and Themes. Toronto: McGraw-Hill Ryerson Ltd., 1980. 
Turenne Sjolander, Claire Turenne. "Cashing in on the "Peace Dividend". In How Ottawa Spends 1996-1997, edited by Gene Swimmer, 253-281. Ottawa: Carleton University Press, 1996.

Urban, Michael Crawford. "A fearful asymmetry: Diefenbaker, the Canadian military and trust during the Cuban missile crisis." Canadian Foreign Policy Journal 21, No. 3 (2015).

Vanguard Staff, "Frigate's new combat systems find international interest." Vanguard, December/January 2015.

Vucetic, Srdjan and Nossal, Kim Richard. "The International Politics of the F-35 Joint Strike Fighter,” International Journal 68, no.1 (2013).

Ward, John. "It's smooth sailing for Canada's new navy." Edmonton Journal, August 25, 2000, A17.

Wattie, Chris. "Air force expansion hobbled by red tape: military sources: Bureaucratic, political concerns slow \$1.3B program.” National Post, September 1, 2005.

Wattie, Chris. "Air force plans to replace fleet: Cheaper to buy new aircraft than to maintain older planes." National Post, August 31, 2005, A12.

Wattie, Chris. “An 'irresponsible' way to run a navy." Ottawa Citizen, October 10, 2004, A3;

Wattie, Chris. "By land, by sea: 'Sea Horse' would make Canada's military able to intervene just about anywhere in the world." Ottawa Citizen, October 9, 2004.

Wattie, Chris. "Competition heats up for Forces planes." National Post, April 7, 2005, A7.

Wattie, Chris. "Forces still waiting for new planes." National Post, February 21, 2005, A4.

Wattie, Chris. "General wants big new warship: Canada's new chief of defence staff has ambitious plan to overhaul all three services of Canadian Forces." Edmonton Journal, February $14,2005$.

Wattie, Chris. "Lobbying, politicking delay planes for air force." National Post, November 16, 2005, A1.

Wattie, Chris. "March of technology leaves forces struggling." The Calgary Herald, October 3, 2004, B5;

Wattie, Chris. "The big boat is coming back: Military to buy largest ship since this beast was scrapped." National Post, April 19, 2004. 
Webb, Stewart and Chris Murray, Canada's hidden plan for predicted failure: Planning for the Introduction of the Canadian Surface Combatant (Calgary: Canadian Global Affairs Institute, 2016), 3 .

Webb, Stewart. Returning To Port: A Needed Course Correction to Keep the National Shipbuilding Strategy off the Rocks. Toronto: The Mackenzie Institute, 2017.

Welch, David A. "The Organizational Process and Bureaucratic Politics Paradigms: Retrospect and Prospect," International Security 17, no 2 (1992).

Williams, Alan S. Reinventing Canadian Defence Procurement: A View from the Inside. Kingston, ON: Defense Management Studies Program, School of Policy Studies, Queen's University, 2006.

Woods, Allan. "Hunt for rescue planes relaunched.” Toronto Star, March 22, 2012, A16.

Wu, Terry and Ross Fetterly. "Canadian Defence Policy: An Analysis.” Canadian Public Policy 16, no. 2 (1990).

\section{Interviews}

Telephone interview with Alan S. Williams, former ADM (Mat), September 5, 2016.

Telephone interviews held with confidential sources on 27 September 2016; 28 September 2016; 5 October 2016; 11 October 2016; 1 December 2016; 8 December 2016; 14 December 2016; 5 January 2017; 12 January 2017; 13 January 2017; 14 January 2017; 17 January 2017; 18 January 2017; 22 January 2017; 23 January 2017; 27 January 2017; 16 February 2017.

Email interview with confidential source held on 30 November 2016 and 6 January 2017. Inperson interviews with confidential sources held on 23 September 2016; 25 September 2016; 26 September 2016; and 10 December 2016. 


\section{$\underline{\text { Appendix A - Ethics Clearance }}$}

\section{Carleton}

U N I VER S IT Y

Canada's Capital University

Research Compliance Office

511 Tory $\mid 1125$ Colonel By Drive

| Ottawa, Ontario K1S 5B6

613-520-2600 Ext: 2517

ethics@carleton.ca

\section{CERTIFICATION OF INSTITUTIONAL ETHICS APPROVAL}

Ethics approval for the following research has been cleared by the Carleton University Research Ethics Board-A (CUREB-A) at Carleton University. CUREB-A is constituted and operates in compliance with the Tri-Council Policy Statement: Ethical Conduct for Research Involving Humans (TCPS2).

Ethics ID: Project \# 104908

Principal Investigator: Jeffery Francis Collins

Co-Investigator(s): Elinor Sloan (Primary Investigator)

Jeffery Francis Collins (Student Research: Ph.D. Student)

Study Title: Executive (In)Decision? Accounting for Delays in Canada's Defence

Procurement Program, 2006-2015 [Jeffrey Collins]

Effective: August 12, 2016

Expires: August 31, 2017.

\section{Restrictions:}

This certification is subject to the following conditions:

1. Approval is granted only for the research and purposes described in the application.

2. Any modification to the approved research must be submitted to CUREB-A. All changes must be approved prior to the continuance of the research. 
3. An Annual Application for the renewal of ethics clearance must be submitted and approved by the above date. Failure to submit the Annual Status Report will result in the closure of the file. If funding is associated, funds will be frozen.

4. A closure request must be sent to CUREB-A when the research is complete or terminated.

5. Should any participant suffer adversely from their participation in the project you are required to report the matter to CUREB-A.

6. Failure to conduct the research in accordance with the principles of the Tri-Council Policy Statement: Ethical Conduct for Research Involving Humans 2nd edition and the Carleton University Policies and Procedures for the Ethical Conduct of Research may result in the suspension or termination of the research project.

Please email the Ethics Coordinators at ethics@carleton.ca if you have any questions.

APPROVED BY:

Date: August 12, 2016

Andy Adler, PhD, Chair, CUREB-A

Shelley Brown, PhD, Vice Chair, CUREB-A 